
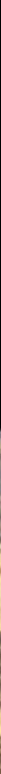

trate

3.

(f)

igen.

(f)

H 0 -

ig

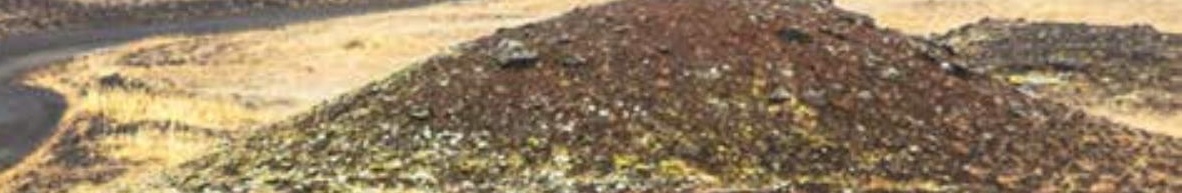

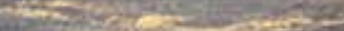

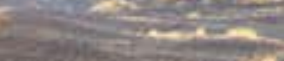




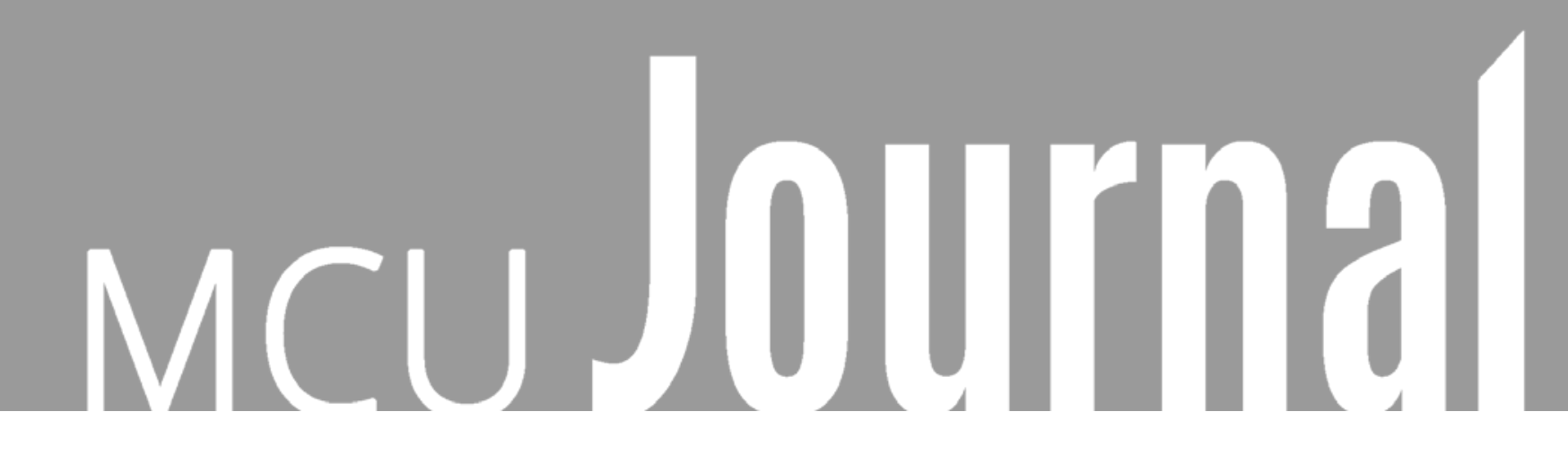

\section{MCUP}

Published by Marine Corps University Press 2044 Broadway Street I Quantico, VA 22134 
MARINE CORPS UNIVERSITY

BGen William J. Bowers, USMC

President

Col Gregory L. Lemons, USMC

Chief of Staff

Richard Jacques

Acting Vice President, Academic Affairs

Mr. Keil Gentry

Vice President, Business Affairs

[forthcoming]

Director, Marine Corps History Division and Gray Research Center

Mr. Paul J. Weber

Deputy Director, Marine Corps History

Division and Gray Research Center

\section{EDITORIAL STAFF}

Ms. Angela J. Anderson

Senior Editor

Mr. Jason Gosnell

Managing Editor

Ms. Stephani L. Miller

Manuscript Editor

\section{EDITORIAL BOARD}

Dr. Rebecca Johnson

Dean, Marine Corps War College, MCU

Dr. James H. Joyner Jr.

Associate Professor of Strategic Studies

Command and Staff College, MCU

Dr. Benjamin P. Nickels

Academic Chair for Transnational Threats

and Counterterrorism

Africa Center for Strategic Studies, NDU

Dr. Christopher S. Stowe

Professor of Military History and

Head, War Studies Department,

Command and Staff College, MCU

Dr. Paolo Tripodi

Head, Ethics Branch

Lejeune Leadership Institute, MCU

Dr. Christopher D. Yung

Donald Bren Chair of Non-Western

Strategic Thought, MCU

\section{ADVISORY BOARD}

Col Mary H. Reinwald, USMC (Ret)

Editor, Leatherneck Magazine

Col Christopher Woodbridge, USMC (Ret)

Editor, Marine Corps Gazette
Established in 2008, MCU Press recognizes the importance of an open dialogue between scholars, policy makers, analysts, and military leaders and of crossing civilian-military boundaries to advance knowledge and solve problems. To that end, MCUP launched the Marine Corps University Journal (MCU Journal) in 2010 to provide a forum for interdisciplinary discussion of national security and international relations issues and how they have an impact on the Department of Defense, the Department of the Navy, and the U.S. Marine Corps directly and indirectly. The MCU Journal is published biannually, with occasional special issues that highlight key topics of interest.

\section{ARTICLE SUBMISSIONS}

The editors are looking for academic articles in the areas of international relations, geopolitical issues, national security and policy, and cybersecurity. To submit an article or to learn more about our submission guidelines, please email MCU_Press@usmcu.edu.

\section{BOOK REVIEWS}

Send an email with a brief description of your interests to MCU_Press@usmcu.edu.

\section{SUBSCRIPTIONS}

Subscriptions to MCU Journal are free. To join our subscription list or to obtain back issues of the journal, send your mailing address to MCU_Press@usmcu.edu.

\section{ADDRESS CHANGE}

Send address updates to MCU_Press@usmcu.edu to maintain uninterrupted delivery.

\section{INDEXING}

The journal is indexed by EBSCO, ProQuest, OCLC ArticleFirst, Defense Technical Information Center (DTIC), JournalSeek, IBZ Online, British Library System, Lancaster Index to Defense and International Security Literature, and AU Library Index to Military Periodicals.

\section{DISCLAIMER}

The views expressed in the articles and reviews in this journal are solely those of the authors. They do not necessarily reflect the opinions of the organizations for which they work, Marine Corps University, the U.S. Marine Corps, the Department of the Navy, or the U.S. government. When necessary, errata will be published immediately following the book reviews.

MCU Journal

(Print) ISSN 2164-4209

(Online) ISSN 2164-4217 


\section{SUPERPOWERS}

What Do We Mean by Great Power or Superpower?:

An Introduction to Concepts and Terms

Ed Erickson, PhD

Great Power Competition in the Age of Islam:

Contemporary Lessons from the Ottoman-Safavid Rivalry

Christian H. Heller

The British Superpower, Irregular Warfare, and Military Honor

T. J. Linzy, PhD

Lithuania under the Soviet Occupation, 1940-41:

Observations and Operations by the United States

Mallory Needleman

Evaluating Russian Strategy in Its Near Abroad:

A Comparison of the Conflicts in Georgia and Ukraine

1stLt Michael Auten

Superpower Hybrid Warfare in Syria

Anthony N. Celso, PhD

The Challenge of the Sole Superpower

in the Postmodern World Order

Keith D. Dickson 
ON THE RADAR

Cyberspace as a Domain of Operations:

What Is NATO's Vision and Strategy?

Jamie Shea, PhD

Toward a European Defense System:

How the European Union Should Improve Its Planning

and Conduct Capacity for the Prevention and

Management of Crises

LtCol Ivan Falasca, ITA Army Marine

Pushing the Limits of Range:

168

Long-range Amphibious Operations

Steven Yeadon

Cities and the Sea:

192

The Urban Role in Maritime Security

Joshua Tallis and Ian Klaus

\section{LITERATURE REVIEW}

Information as the Cyberwar

Matthew J. Flynn, PhD

\section{REVIEW ESSAY}

The Bomb and the Trolley:

Assessing China's Geopolitical Challenges

Guillaume Lasconjarias

\section{BOOK REVIEWS}

The Soviet-Israeli War, 1967-1973: The USSR's Military

Intervention in the Egyptian-Israeli Conflict by Isabella Ginor and Gideon Remez

Reviewed by Mark T. Clark, PhD

Restraint: A New Foundation for U.S. Grand Strategy

by Barry R. Posen

Reviewed by Maj A. B. Christman

Over the Horizon: Time, Uncertainty, and the Rise of Great Powers

by David M. Edelstein

Reviewed by Carrie A. Lee 
No Miracles: The Failure of Soviet Decision-Making

in the Afghan War by Michael R. Fenzel

Reviewed by Joseph Stieb

Near Abroad: Putin, the West and the Contest over Ukraine

and the Caucasus by Gerard Toal

Reviewed by Martin J. Kozon

Military Service and American Democracy: From World War II to the Iraq and Afghanistan Wars by William A. Taylor

Reviewed by Jeremy P. Maxwell

A Military History of Afghanistan: From the Great Game

to the Global War on Terror by Ali Ahmad Jalali

Reviewed by Peter Mansoor

America's Digital Army: Games at Work and War

by Robertson Allen

Reviewed by Leonard Wong, PhD

Algeria Modern: From Opacity to Complexity

edited by Luis Martinez and Rasmus Alenius Boserup

Reviewed by Benjamin P. Nickels, PhD

The Prometheus Bomb: The Manhattan Project

and the Government in the Dark by Neil J. Sullivan

Reviewed by J. N. Campbell 



\section{From the Editors}

There are a variety of reasons to study geopolitical rivalries, and analysts, officers, and politicians are rediscovering such reasons amid the tensions of the last several years. The best reason to study geopolitical rivalries is the simplest: our need to better understand how power works globally. Power not only recurs in human and state affairs but it is also at their very core. Today's new lexicon-superpower, hyperpower, and great power-is only another reminder of the reality of the various ways that power manifests itself. Power protects and preserves, but a polity without it may be lost within mere decades. Keith D. Dickson's article in this issue of $M C U$ Journal, "The Challenge of the Sole Superpower in the Postmodern World Order," illuminates how fuzzy some readers may be in their understanding of this problem; his article on postmodernism calls us to the labor of understanding and reasoning through the hard realities.

Ed Erickson's survey of modern power is replete with cases in which a grand state simply fell, as from a pedestal in a crash upon a stone floor. Modern Japan, always richly talented, rose suddenly as a world actor in the late nineteenth century, but the Japanese Empire fell much more quickly in the mid-twentieth century. A state's power-or lack thereof-is an unforgiving reality.

This issue of MCU Journal, with its focus on rivalries and competition between states, is refreshingly broad in its selection of factors-from competing for or generating power. Dr. Erickson recalls that Alfred Thayer Mahan settled on six conditions for sea power, all still vital. Other authors writing for this issue emphasize, by turns, sea power (Steven Yeadon, Joshua Tallis, and Ian Klaus); cyberpower (Jamie Shea); alliances (T. J. Linzy and Ivan Falasca); information (Dickson); and proxies (Michael Auten, Anthony N. Celso, and others).

First Lieutenant Auten's article details how Russia's raw power suppression of foes in Syria, Georgia, and Ukraine casts a shadow over our own concerns with Russia's political and strategic intentions. Moscow's ally, Bashar al-Assad's regime in Syria, has survived impossible odds_-and American interventionby burning its citizen-rebels with chemical warfare or barrel bombs full of nails and explosives. 
None of the authors in this issue are crying that the apocalypse approaches, but their warnings of more limited threats to global stability warrant attention. The government believed creating U.S. Cyber Command in 2009 and smaller offices in each of our military Services helped inure us against the latest threat. And yet, we also have been rudely surprised by the lengths some nation-states will go to acquire a position of power; the 2016 U.S. elections clearly illuminated the cyber threats at play, as author Jamie Shea elaborates.

Some thought in 1990 that the United States stood alone on a new summit with the collapse of the Soviet Union. But in the last few years, China and Russia have drawn themselves up confidently. The former works with prodigious economic powers in a new combination of enterprising capitalism and state Marxism-Leninism. And consider the spectacular audacity in China's "disappearing" of one of its own citizens, whose office was the presidency of the century-old international policing agency, Interpol. The other great competitor, the "new Russia," advances with brazen land grabbing that drags the near abroad at its borders closer, and after each grab, Moscow crisply tells international observers to move along. This style of incremental land grabbing is more than Vladimir Putin's style, because it parallels Otto von Bismarck's successful and limited (conventional) wars that expanded German lands and integration in the 1860s.

These and many other subjects, contemporary or historical (Mallory Needleman's article on Lithuania under the Soviet occupation and Christian H. Heller's article on the Ottoman-Safavid rivalry), make this fall issue a solid contribution to revivified studies of how power comes and goes in the world. This collection of articles serves only as an introduction to this wide-ranging topic and offers a brief look at historical and contemporary forays into the concept of power that will likely play out in the near future.

The remainder of the journal rounds out with a selection of review essays and book reviews that continues our focus on power but also highlights continuing challenges in national security and international relations. The coming year will be busy for the $M C U$ Journal editors as we work to provide issues on a diverse range of topics relevant to the study of militaries and defense. The upcoming spring 2019 issue opens a debate on the economics of defense and the costs of making war and peace. We also are accepting submissions for the fall 2019 journal's consideration of great power competition and how the U.S. military, particularly the Marine Corps, might fare in the face of peer competition, soft/hard power plays, and the changing character of war. We look forward to hearing your thoughts on these topics and to your future participation. Join the conversation on the MC UPress Facebook and Twitter pages or communicate with us via email at MCU_Press@usmcu.edu. 


\title{
What Do We Mean by Great Power or Superpower? An Introduction to Concepts and Terms
}

\author{
Ed Erickson, PhD
}

\begin{abstract}
This article serves as an introduction to what is generally meant by such terms as great power, superpower, hyperpower, middleweight power, power of world influence, regional hegemon, and new great power, as well as what is meant by the term balance of power in the context of national power relationships. This article also provides a brief chronological explanation of when these terms are used historically, the measurements by which nations are added or dropped from the category, and some observations about the utility of such a vocabulary. The article concludes with contemporary understandings that increasingly include such factors as attitudes, concepts, language, and modes of life as essential capabilities in assessing national power.
\end{abstract}

Keywords: great powers, new great powers, superpowers, balance of power, hyperpower, national power

$\mathbf{T}$ here is vast, extant literature regarding the conceptual notion of great powers; however, for the purposes of this article, the author has selected three books as representative of how scholars during the past 50 years have come to their understandings of the terms. These books are A. J. P. Taylor's The Struggle for Mastery in Europe, 1848-1918; Paul Kennedy's The Rise and Fall of the Great Powers: Economic Change and Military Conflict from 1500 to 2000; and Goedele De Keersmaeker's Polarity, Balance of Power and Interna-

Dr. Edward J. Erickson is a scholar-in-residence at the Clark Center for Global Engagement at the State University of New York at Cortland. He is a retired professor of military history from the Marine Corps University. 
tional Relations Theory: Post-Cold War and 19th Century Compared. ${ }^{1}$ The author recommends these books, which are engagingly well-written, as starting points for readers new to the field. ${ }^{2}$

The phrase great power first appears academically in 1833 in an essay by German historian Leopold von Ranke, titled "The Great Powers." ${ }^{3}$ He wrote that "the general course of history, he [von Ranke] concluded, was from the late seventeenth century conditioned by shifting power constellations among the great powers, not simply by constellations among all European nations. The great powers (France, England, Russia, Austria, and Prussia) were in turn conditioned by their specific domestic conditions." "Von Ranke also advanced in his lectures and writings the concept of the balance of power. ${ }^{5}$ Notably, he also limited his ideas to European nations. Von Ranke's fundamental conceptsshifting relationships, balance of power, domestic strength, and Eurocentric inclusion-distinguished the field until the post-Second World War period. During the Cold War, the term superpower replaced the term great power which, in turn, was replaced in the early 1990s by a new term, hyperpower (used to identify exclusively the United States). In the twenty-first century, other terms, such as power of world influence, regional hegemon, and new great power, have entered the vocabulary of power relationships.

This article serves as an introduction to what is generally meant by such terms as great power, superpower, hyperpower, middleweight power, power of world influence, regional hegemon, and new great power, as well as what is meant by the term balance of power in the context of national power relationships. This article also provides a brief chronological explanation of when these terms are used historically, the measurements by which nations are added or dropped from the category, and some observations about the utility of such a vocabulary. Readers will note that, in the past, ideas about these matters devolved to the capability and capacity to wage war by projecting military power or to the ability to influence other nations in some coercive way. Finally, the article concludes with contemporary understandings that increasingly include factors such as attitudes, concepts, language, and modes of life as essential capabilities in assessing national power.

\section{Measuring "Power"}

Taylor, Kennedy, and De Keersmaeker published their books in 1954, 1987, and 2016 and, while they differ topically and thematically, all three rely on the quantifiable analysis of economic (industrial and raw materials), financial (gross domestic product and military expenditures), demographic (populations and capabilities), and military (numbers of weapons systems) tabular data. We point this out because, while there is no precise universally accepted definition for the term great power, there appear to be universally accepted standards by which a 
great power is measured. Assessments of resources as noted above, both natural and man-made, are a unitary theme in the literature of this subject. The three authors above reflect this dynamic.

When assessing the impact of specific resources, we might also note that, according to historians MacGregor Knox and Williamson Murray, five military revolutions have occurred since the world moved out of medieval times. ${ }^{6}$ Chronologically, these revolutions hinged on the understanding, and marshaling in militarily useful ways, of the following resources: financial, demographic, industrial, the combination of the preceding three to wage attritional warfare, and scientific. It cannot be understated how closely changes in great power status and relationships mirror Knox and Murray's periodization of changes in military affairs (table 1).

The ability of a nation to recognize and adapt to military revolutions coincides with what is commonly called the rise and fall of great powers. Combining these ideas, the importance of mobilizing national resources in a utilitarian way, both natural and man-made, is a critical determinant in achieving or losing great power status. Scholars exploring this subject (illustrated by the work of Taylor, Kennedy, and Goedele De Keersmaeker, for example), at some point invariably gravitate toward the measurement and use of resources to support their arguments.

\section{The Emergence of Great Powers}

Paul Kennedy begins his classic work around 1500, however, we begin here with the Treaty of Westphalia in 1648 as the defining genesis of the term the Great Powers of Europe. 'The treaty ended the Thirty Years' War between the Roman Catholic and Protestant powers of Europe. It is notable historically for establishing the principle of sovereign states (also establishing the idea of

Table 1. Military revolutions according to Knox and Murray

\begin{tabular}{ll} 
Military revolution 1: & $\begin{array}{l}\text { The seventeenth-century creation of the modern state and } \\
\text { modern military institutions (centralized state financing en- } \\
\text { abled nation-states to field professional gunpowder armies) }\end{array}$ \\
Military revolution 2: & $\begin{array}{l}\text { The French Revolution (conscription and national mobilization } \\
\text { led to armies and navies on a scale previously unseen) }\end{array}$ \\
Military revolution 3: & $\begin{array}{l}\text { The Industrial Revolution (the factory system enabled the arm- } \\
\text { ing of huge forces with mass-produced weapons) }\end{array}$ \\
Military revolution 4: & $\begin{array}{l}\text { The First World War (the irrevocable combination of its three } \\
\text { predecessors that enabled the waging of long-term, attritional, } \\
\text { total war) } \\
\text { The Nuclear Age (nuclear weapons and ballistic missiles created } \\
\text { the capability to destroy nations) }\end{array}$ \\
\hline
\end{tabular}


nation-states) as well as European norms of noninterference in another state's domestic affairs. Importantly, it established the concept of a balance of power designed to keep the peace in Europe by creating conditions that made aggression between nation-states very difficult.

In addressing the treaty of 1648 , A. J. P. Taylor illustrated how quickly great powers can either attain or lose great power status:

Of the Powers indisputably ranked as Great at the Congress of Westphalia in 1648, three-Sweden, Holland, and Spainceased to be Great and one-Poland-ceased to exist before the close of the eighteenth century; their place was taken by Russia and Prussia, two states hardly within notice a hundred years before. ${ }^{8}$

In understanding why this happened, Kennedy asserted that it is the interaction between leading states striving to enhance their wealth and power that explains these changes. He argued that "the relative strengths of the leading nations in world affairs never remain constant, principally because of the uneven rate of growth among different societies and of the technological and organizational breakthroughs which bring a greater advantage to one society than to another." Therefore, there are a variety of factors that determine a nation's great power status.

Regardless of the chronological point of origin of the term great powers, the extant literature relies on tabular data to establish the resources needed to become a great power and to maintain great power status. In this foundational period, scholars measured such variables as increases in military manpower, wartime expenditures and revenues, and the size of armies and navies. In this way, it became possible to measure capability (what could be done) and capacity (the extent to which something could be done) in both absolute and relative terms. ${ }^{10}$ This led then to the ability of scholars to weigh variables and rank order power.

\section{The Emergence of the Balance of Power}

Taylor attributed the long periods of general peace in Europe to the maintenance of the balance of power. ${ }^{11}$ The idea of such a balance of power emerged in European diplomacy at the Treaty of Utrecht in 1713 when the participating states formed a European system designed to counter the hegemonic ambitions of the French king, Louis XIV, whose repeated wars had endangered the status quo. This period in European history was marked by the establishment of coalitions designed to keep France in check but which also served to prevent continental-scale wars (as the Thirty Years' War had been). This is not to say that localized state-on-state war did not occur, and there were three such wars that changed the status of great power nations. 
The United Kingdom emerged as a great power with the conclusion of the War of the Spanish Succession (formalized by the Treaty of Utrecht in 1713), an event that would prove to have profound consequences for both Europe and for the world. Spain's decline began about this time, and within 50 years, it was finished as a great power. Spain's dilemma was that continual wars and the costs of its empire drained the treasury, which was dependent on the American colonies producing gold and silver. In the end, Spain's small population and lack of a viable domestic economy reduced it to penury.

Swedish power peaked under King Charles XII, but his military campaigns led to disastrous defeat in 1721 in the Great Northern War. Sweden's small military and naval forces were excellent but fragile in that the tiny population and economy could not replace losses. The overextension into an endless campaign in Russia led to the defeat of Sweden and to the emergence of Romanov Russia as a great power. Sweden would continue to be an important second-tier power through the end of the Napoleonic Wars (1803-15). Likewise, 50 years later, the Dutch joined the ranks of the second-tier powers after the British defeated the United Provinces (Holland) in the Third Anglo-Dutch War of 1674. Holland's decline had begun earlier in a series of wars that forced it to field both an army and a navy.

Unfortunately, Poland also left the field permanently when the powerful absolute monarchs of Prussia, Russia, and Austria-Hungary conspired and orchestrated the partition of the country in 1795, destroying it as a nation-state until its resurrection in 1919. Thus, by the time of the French Revolution in 1789, the great powers consisted of Austria-Hungary, the United Kingdom, France, Prussia, and Russia. In turn, the rise of Napoleon Bonaparte after 1799 reinforced the formation of new European coalitions designed to prevent French hegemony on the continent.

The wars of Napoleon further confirmed the status of the existing great powers of Europe. The French emperor crushed Prussia, Spain, and AustriaHungary in 1806,1807 , and 1809 , respectively. ${ }^{12}$ Napoleon's disastrous invasion of Russia in 1812 led to a European-wide coalition that ended his dreams of European hegemony. Because of Lazare Carnot's innovations in national mobilization and conscription in this period, modern scholars added populations and per capita income to their growing list of variables by which to calculate power relationships and rank ordering.

\section{The Congress of Vienna 1815 and the Concert of Europe}

Engineered by Austro-Hungarian foreign minister prince Klemens von Metternich, the Congress of Vienna concluded a 20-year period of nearly continuous warfare between the European nations and France. The signatories included 
Austria-Hungary, the United Kingdom, France, Prussia, and Russia, as well as second-tier powers Portugal, Spain, and Sweden. In terms of European stability, the most important outcome of the congress was the establishment of what has been called the Concert of Europe. This term encompassed a system of cooperation based on a soon-to-be-defunct great power alliance, overlapping agreements and treaties, and the willpower of Metternich himself. Metternich's system was designed keep France at bay by maintaining a balance of power that pitted at least three of the four other great powers opposite France. France briefly joined the alliance but withdrew. Metternich also was keenly aware of the economically and socially driven unhappiness of the lower classes of European nations and simmering rebellious intentions of captive minorities living under the dynastic empires. In turn, Metternich mobilized the fears of European monarchs and governments to agree to support one another in crushing revolutionary movements. The system triumphantly emerged from a continent-wide wave of revolutions in 1835 and 1848 by ensuring that the reigning governments and dynasties remained in power.

The Crimean War (1853-56) brought the United Kingdom and France into armed conflict with Russia, but the war proved to be inconclusive and not particularly expensive to any of its participants. The Concert of Europe endured and, in 1861, the unification of Italy created a sixth great power of Europe. At this point, Prussian foreign minister prince Otto von Bismarck crossed the stage of history by delivering the famous "Blood and Iron" speech to the Prussian Reichstag in 1863, proclaiming that German unification under Prussian leadership could only be achieved by using war as a foreign policy tool. In short order, Prussia waged and won the Danish-Prussian War of 1864, the Austro-Prussian War of 1866, and the Franco-Prussian War of 1870, allowing Bismarck to orchestrate German unification in 1871. The impact of Bismarck on the European system would be felt for the next 80 years.

\section{Bismarck's Alliances and the Balance of Power}

The defeat of France at the hands of Prussia and the German states upset a European balance of power that had been in place since the reign of Louis XIV. Indeed, the primacy of France and its unchallenged position as the most powerful nation in Europe had been the driving force in how European monarchs and diplomats thought about power relationships. Literally overnight a new Germany displaced France in the computations and alignment of the European balance of power.

Bismarck's name and reputation has long been associated with Prussian and German militarism. However, it is important to remember that after German unification Bismarck's activities increasingly turned to domestic policies designed to strengthen Germany internally. He also turned to the establishment 
of a system of defensive alliances designed to protect the new nation. Beginning in 1873 with the Three Emperors' League (Austria-Hungary, Germany, and Russia), Bismarck subsequently created the Dual Alliance with AustriaHungary in 1879 . The Dual Alliance was designed to counterbalance a resurgent, angry, and heavily armed France, and it was purely defensive in nature. Bismarck's objective was to ensure that France would not attack Germany in an effort to recover lost provinces or simply for revenge. Unfortunately, an unforeseen consequence of this was that France sought an alliance with Russia, leading to a period of equating the balance of power in Europe with the strength and position of two opposing alliance systems. While the world was not what we might term bipolar in the sense of two superpowers, it is fair to assert that European security affairs from 1879 to 1914 were seen in terms of balancing alliance polarity.

The rise of the industrialized state, railroads, and mass production in this period led to scholars adding more variables for consideration in their calculations of power. In particular, coal, iron, and steel production became important, as did the relative share of world manufacturing output. ${ }^{13}$ Census data and public disclosures of contracts and national budgets made it possible to measure the percentage of national income devoted to armaments and the per capita share necessary to maintain it. ${ }^{14}$

Although Kaiser Wilhelm II added colonialism and imperialism to the plate of German aspirations, Germany remained essentially rooted in European affairs. By 1914, the opposing alliances consisted of the Triple Entente composed of the United Kingdom, France, and Russia, which was counterbalanced by the Triple Alliance composed of Austria-Hungary, Germany, and Italy. Thus, all six of the then great powers were tied to a bipolar interpretation of security affairs in Europe. Although Italy would initially remain neutral at the onset of the First World War, replaced by the second-tier Ottoman Empire, which joined the Germans and Austro-Hungarians, this system endured. Most historians also assert that the alliance system dragged somewhat reluctant great powers into an unwanted general war over a localized Balkan crisis between Austria-Hungary and Serbia. ${ }^{15}$ In any case, including colonies in the equations, the Triple Entente powers had one-third more people, double the manufacturing capacity, and the immeasurable advantage of position and command of the seas against their opponents.

After the Ottomans entered the war in November 1914, the term Central Powers, composed of the three aforementioned participants (plus the Bulgarians) replaced the term Triple Alliance, while the Triple Entente members came to be called the Allies, which also included newcomer Japan. In 1917, Czarist Russia collapsed and the United States entered the war, bringing the net total of Allied resources to an even higher level of superiority. The war ended with 
the Central Powers defeated and in a state of collapse. In the end, many historians attribute their defeat to exhaustion caused by a resource-deficient ability to wage long-term, attritional warfare.

The United States and Japan had since 1905 actually ranked as de facto great powers-Japan because it had defeated the Russians and acquired an empire in eastern Asia, and the United States because of its industrial strength and new blue water navy. However, both powers were essentially hemispheric in their approach to world affairs. The United States, in particular, had a long tradition of noninvolvement in European affairs.

The Treaty of Versailles in June 1919 reordered the great powers of Europe and another round of adding and dropping nations ensued. The somewhat larger number but clearly reordered great powers of 1919 consisted of the United Kingdom, France, Germany, Italy, Japan, the Union of Soviet Socialist Republics (the Soviet Union or USSR), and the United States. Importantly, this is the point where the Euro-centricity of the term great powers became obsolete and was relegated to a historical curiosity. After 1919, the term great powers took on a global context, and we might note that in terms of measurable data, the inclusion of Italy became problematic.

The literature evaluating these matters begins to include aspects of technology and production capacity as these affect national power. By 1939, Italy, for example, had the trappings of a great power-a large army and navy, colonies, and power-projection capabilities (as demonstrated in the Spanish Civil War and the conquest of Ethiopia). However, as would be seen in the Second World War, Italy did not have the resources, especially in manufacturing capacity, to sustain itself under the demands of long-term, attritional warfare.

\section{The Superpowers}

The end of World War II concluded the great power system of multilateral national security that had existed since the reign of Louis XIV. The defeat of Germany, Italy, and Japan led to their occupation and demilitarization; moreover, Germany lost one-third of its territory. The industrial base and infrastructure, as well as a massive amount of civilian housing of Germany and Japan, were destroyed by Allied strategic bombing. The United Kingdom and France, both victors in the war, were pauperized by the costs of the war and both faced restive colonial peoples in their overseas empires. China also was a victor, but it remained a populous but underdeveloped nation. Their reduction to second-tier status inevitably followed. This left the Soviet Union in a position of dominant supremacy in the Eurasian landmass and the United States in command of the seas and with a dominant air capability (including atomic bombs). The term superpower soon evolved to characterize the capability, capacity, and role of these two nations in the postwar world, which was also defined as bipolar. 
The United Kingdom and France attempted to maintain the illusion that they remained great powers, at least until the mid-1950s, but after fighting a losing series of colonial wars they uneasily accepted their reduced position. The balance of power concept reemerged as the United States established the North Atlantic Treaty Organization (NATO), while the Soviet Union established an opposing Warsaw Pact. This period became known as the Cold War and was characterized as a wider view of the components of national power, which included nuclear weapons and intercontinental delivery systems but also encompassed puppet and client states, irregular warfare, and information warfare.

Through the acquisition of nuclear weapons, the United Kingdom and France reentered the field as middleweight powers possessing powerful but limited strategic reach and global influence. The establishment of a strong, centralized government in China led to its rise as an emerging regional power by the 1960s. China was soon joined by India, Israel, and Pakistan, which also acquired nuclear weapons, giving them powerful regional military capabilities. Approaching the end of the Cold War, the United States and the Soviet Union maintained their status and position primarily through a large resource base, which enabled them to field both significant capability and almost unlimited capacity.

Much to the surprise of world leaders, military intelligence analysts, subject matter experts in security affairs, and the world population, the fall of the Berlin Wall in November 1989 led directly and quickly to the collapse of the Soviet Union. Unlike previous changes in great power status, defeat in armed conflict did not cause the dissolution of the Soviet state. However, a strong argument can be made that the Soviets could not bear the financial costs of an extended period of confrontation with the United States in a Cold War. Many scholars feel that the command economy of the Soviet system proved inadequate to the task of maintaining a resource-based armaments competition with the United States. ${ }^{16}$

\section{The Short but Unlamented Age of Hyperpower}

In 1999, French foreign minister Hubert Vedrine defined the United States as a hyperpower, a new term that best described "a country that is dominant or predominant in all categories." 17

Superpower, in Vedrine's view, was an obsolete Cold War term reflecting largely the military capabilities of both the Soviet Union and the United States. He asserted that "the breadth of American strength is unique, extending beyond economics, technology or military might to 'this domination of attitudes, concepts, language and modes of life'." ${ }^{18}$ In essence, Vedrine added cultural power to the growing list of great power resources that could be mobilized to exert influence and power. Certainly, the influence and power of the United States at the dawn of the twenty-first century appeared unchallenged. 
Vedrine went on to describe France as a power of world influence, a category that also included Germany, the United Kingdom, Russia, China, Japan, and India. This redefinition of power status is important because it signaled a shift in the interpretation of power from something essentially focused on military strength to something other than the physical resources necessary for waging war. While a case can be made that the United Kingdom, France, Russia, and China remained military powers with global capability and reach, only Russia retained a capacity to match the American nuclear arsenal. No military argument can be made that Germany, Japan, or India had significant powers beyond their economic capabilities and capacity. There is no question, however, that these nations were significant in the calculus of power relationships and status entering the twenty-first century.

American interventions in Afghanistan and Iraq in 2001 and 2003 led to continuing long-term wars that drained its treasury and imposed crippling restrictions on the capability and capacity of its military and naval forces to respond to other crises. Continuing interventions after the Arab Spring in 2011 imposed further liabilities on already strained American military power by adding quasi-wars in Libya, Somalia, South Sudan, Niger, Yemen, and Syria to American commitments. The rise of a new American isolationism manifested itself in 2016 with the election of Donald J. Trump to the presidency on a promise of withdrawing from expensive overseas military adventures and protecting the American industrial base. It is clear that the United States no longer enjoys the resource advantage or the cultural supremacy predicted by the French foreign minister in 1999.

An associated term that emerged in this timeframe is regional hegemon, which is used to describe nations seeking to dominate adjacent geographic areas and geopolitical entities. Countries such as Iran, Saudi Arabia, and Turkey are considered aspiring regional hegemons. Whether these countries have the resources to match their aspirations remains to be seen. On a larger scale, Russia and China certainly have the resources to assert hegemony in the near abroad and the South China Sea, respectively. ${ }^{19}$

\section{Conclusion: "What Comes Next?"}

There is a growing literature concerning what will come next in defining and determining power status and power relationships in the coming century. Looking back at Paul Kennedy's work, the problem of predicting an uncertain future becomes immediately obvious. Kennedy predicted that the Soviet Union would gradually weaken and lose its position of superpower status, but he missed its imminent collapse. Likewise, Kennedy saw Japan as an emerging power whose power status would inevitably increase. ${ }^{20}$

In 2004, strategic thinker Thomas P. M. Barnett redefined power status 
in terms of new core powers, whose strength lay in being inside a perimeter of integrated economies. ${ }^{21}$ Security specialist George Friedman followed this by postulating in 2009 that Poland, Turkey, and Japan would emerge in the midtwenty-first century as new great powers. ${ }^{22} \mathrm{~A}$ recent article in the American Interest asserted that there are now eight great powers in the world. These are, in the order of power status from strongest to less strong: the United States, China, Japan, Russia, Germany, India, Iran, and Israel. ${ }^{23}$ One might ask, how valid are these predictions and judgments? What tabular data and measurements support such assertions? How do we weight new capabilities and capacity measurements such as cyberspace, social media leveraging, nonstate mercenaries, and ideologies in our future assessments?

Other terms entered the vocabulary in the new century that offered nuanced understanding of power relationships. Professor John J. Mearsheimer, a noted international security policy specialist at the University of Chicago, advanced the idea of offshore balancers to describe the role of interventionist naval powers. ${ }^{24}$ Mearsheimer noted similarities in the case of the United States in the early twentieth century that mirrored the case of the United Kingdom in earlier centuries in terms of the selective application of power projected from the sea. This changed, of course, after the Second World War with the permanent forward presence of American forces in Western Europe and northeast Asia. In this regard, Mearsheimer was careful to make the point that, during the postwar peace, the United States was committed to containment rather than to balancing power to maintain peace. ${ }^{25}$

We might circle back to Knox and Murray's thoughts on military revolutions and ask whether absolute or relative measurements of military capability and capacity are appropriate in an assessment of power status in the twenty-first century. Certainly nations like Germany, India, and Japan are not great powers as that word has been understood since 1648. Perhaps the world is on the cusp of a sixth military revolution, which includes some sort of a soft power approach that enables nations to exert influence and nonkinetic force in ways that redefine the character of war. If this is true, then we should ask how such attributes of nonhard power might be measured and assessed in the future security environment.

While soft power is a modern term, historians and theorists have been thinking about the issue since the nineteenth century. Nothing illustrates this more clearly than the ideas of American strategic thinker Captain Alfred Thayer Mahan, who was a lecturer in naval history and tactics at the United States Naval War College from 1885 to 1896. In his seminal work, The Influence of Sea Power on History, Mahan advanced the idea that sea power rested on six general principal conditions: "1. Geographical position, 2. Physical conformation (including natural resources and climate), 3. Extent of territory, 4. Number of population, 5. Character of the people, 6. Character of the government (including national 
institutions)." ${ }^{26}$ Although Mahan's books concerned naval power, his assertion was that the character of both a people and their government had something to do with the creation of power potential beyond the physical realm. Mahan's ideas were harbingers of more sophisticated thinking about the nature and application of national power. In some ways, it is fair to state that Mahan's ideas were an earlier and less sophisticated form of Hubert Vedrine's remarks on attitudes, concepts, language, and modes of life as essential components of national power.

Several years after Mahan's seminal work, American historian Frederick Jackson Turner delivered a paper at the World's Columbian Exposition in Chicago titled "The Significance of the Frontier in American History." ${ }^{27}$ Known today as the "Frontier Thesis," Turner advanced the idea that Americans had been an inwardly focused people bent on taming the frontier and westward expansion. Jackson's corollary to this idea was, with the frontier essentially tamed in 1893, Americans would have to turn their ambitions outward and become more internationally engaged. While this may seem to be an obvious statement today, it was certainly less so to Jackson's audience and, similarly to Mahan's ideas-Jackson's thesis reflected the aspirations and character of a people more than their raw physical and geographical potential.

Combining these ideas, it seems clear that, while much of the discourse about great powers has rested on, and continues to rest on, objective assessments of measurable data of resources and technology, we must also pay attention to less well-defined intangibles. These intangibles might include, but are not limited to, the character and aspirations of a people, the form of government, a nation's culture, and the kinds of leaders that a culture produces. Therefore, rather than leave the reader with a defined thesis about power, this author is inclined to suggest that future assessments of national power must necessarily include subjective intangibles interwoven with objective measurements and information.

\section{Notes}

1. A. J. P. Taylor, The Struggle for Mastery in Europe, 1848-1918 (Oxford: Oxford University Press, 1954); Paul Kennedy, The Rise and Fall of the Great Powers: Economic Change and Military Conflict from 1500 to 2000 (New York: Random House, 1987); and Goedele De Keersmaeker, Polarity, Balance of Power and International Relations Theory: Post-Cold War and 19th Century Compared (New York: Palgrave Macmillan, 2017).

2. See John J. Mearsheimer, The Tragedy of Great Power Politics, updated edition (New York: W. W. Norton, 2014) for an extremely readable introduction to these matters.

3. Ernst Schulin, "Ranke's Universal History and National History," Syracuse Scholar 9, no. 1 (1988).

4. $\quad$ Schulin, "Ranke's Universal History and National History," 4.

5. De Keersmaeker, Polarity, Balance of Power and International Relations Theory, 214.

6. MacGregor Knox and Williamson Murray, eds., The Dynamics of Military Revolution, 1300-2050 (Cambridge: Cambridge University Press, 2001), 13-14. 
7. The Treaty of Westphalia is generally accepted as the historical point where nation-states become a term of use in European affairs, which conforms to Murray and Knox's explanation of military revolutions.

8. Taylor, The Struggle for Mastery in Europe, xxii.

9. Kennedy, The Rise and Fall of the Great Powers, xv-xvi.

10. Kennedy, The Rise and Fall of the Great Powers, xiii.

11. Taylor, The Struggle for Mastery in Europe, xix.

12. David G. Chandler, The Campaigns of Napoleon, vol. 1 (New York: Macmillan Publishing, 1966), 443-502, 593-658, 663-732.

13. Kennedy, The Rise and Fall of the Great Powers, xiii.

14. Taylor, The Struggle for Mastery in Europe, xxviii-xxix.

15. For a representative narrative see, for example, Hew Strachan, The First World War (London: Simon \& Schuster, 2003), 1-31.

16. Lawrence Freedman, Strategy: A History (Oxford: Oxford University Press, 2013), 214.

17. "To Paris, U.S. Looks Like a 'Hyperpower'," International Herald Tribune, 5 February 1999.

18. “To Paris, U.S. Looks Like a 'Hyperpower'."

19. The near abroad is a Russian geopolitical term meaning the former Soviet Socialist Republics that comprised the USSR.

20. Kennedy, The Rise and Fall of the Great Powers, 446-72.

21. Thomas P. M. Barnett, The Pentagon's New Map: War and Peace in the Twenty-First Century (New York: G. P. Putnam's Sons, 2004), 107-90.

22. George Friedman, The Next 100 Years: A Forecast for the 21st Century (New York: Doubleday, 2009), 212-23.

23. Walter Russell Mead and Sean Keely, "The Eight Great Powers of 2017," American Interest, 24 January 2017.

24. Mearsheimer, The Tragedy of Great Power Politics, 234-66.

25. Mearsheimer, The Tragedy of Great Power Politics, 265-66.

26. Alfred Thayer Man, The Influence of Sea Power upon History, 1660-1783 (Boston: Little, Brown, 1890), 28-29.

27. Frederick Jackson Turner, "The Significance of the Frontier in American History," in The Frontier in American History (New York: Henry Holt, 1921). 


\title{
Great Power Competition in the Age of Islam Contemporary Lessons from the Ottoman-Safavid Rivalry
}

\author{
Christian H. Heller
}

\begin{abstract}
Proponents of Thucydides's Trap warn that conflict between a rising power and an established power may be impossible to avoid. The OttomanSafavid rivalry 500 years ago is evidence of this theory. Contentious economic interests, competing geographic concerns, dissimilar cultures, and differing political systems led to centuries marked by periods of both peace and conflict. The rivalry provides six lessons: war may be unavoidable but does not need to be catastrophic; domestic unity can lead to international disunity; economic interdependence does not abate economic conflict; alliances can and will shift rapidly; expect foreign interference in domestic affairs; and finally, rivalry can last for centuries.
\end{abstract}

Keywords: Thucydides's Trap, Ottoman, Safavid, Ottoman-Safavid rivalry, great power

\section{$\mathbf{T}$}

he Harvard University academic Graham Allison and the Thucydides's Trap Project at the Belfer Center for Science and International Affairs dedicate research to the study of great power competition. The Thucydides's Trap, named after its author in his History of the Peloponnesian War, is illustrated as follows: "It was the rise of Athens and the fear that this instilled in Sparta that made war inevitable." ${ }^{1}$ Applying this framework to an older Middle

Christian H. Heller is a graduate of the United States Naval Academy and holds a master's of philosophy in modern Middle Eastern studies from the University of Oxford. He is currently serving in the U.S. Marine Corps as an intelligence officer and Middle East/North Africa regional affairs officer. 
Eastern rivalry provides insights into power relationship dynamics. The competition between the Turkish Ottoman Empire and the Persian Safavid Empire between the sixteenth and seventeenth centuries presents lessons in how superpowers with commercial interdependence and cultural differences contend for geographic and economic supremacy.

The great powers' areas of influence directly intersected. The Islamic empires competed over border regions, such as Iraq and eastern Anatolia, and were economically interdependent. Just as China and America today rely on each other for continued economic prosperity, so too did the Ottomans and Safavids have long-lasting vital trade dependencies that suffered during times of conflict. Additionally, there were many distinctions between the two empires regarding their domestic populations' opinions, internal political beliefs, and cultural differences. The shared language, religion, and political beliefs following World War I and World War II helped the United States and United Kingdom avoid war early in the twentieth century as international power shifted west to North America. These conditions were absent for the Ottomans and Safavids.

Six major themes appear from a review of the Ottoman-Safavid rivalry. First, there were alternating periods of war. The outbreak and cessation of war is often beyond the hands of a single person or group of people, even if that individual is theoretically an all-powerful imperial ruler surrounded by a handful of close advisors. Second, domestic attempts at cultural homogeneity, while useful for state building and domestic consensus building, can lead to unintended foreign conflicts. Third, economic interdependence does not abate economic conflict, and economic conflict can rapidly lead to military conflict. Fourth, third-party and diplomatic alliances can shift unexpectedly and change a nation's strategic position virtually overnight. These shifts should be expected and managed. Fifth, external interference with a competitor's domestic matters has existed throughout history. The Ottoman sultan and Safavid shah launched regular subversive campaigns against the other. Finally, and perhaps most obviously, great power competitions lead to long-lasting and seemingly irreversible changes, especially for the places and persons competed over by rival powers. Decisions made today between powers may in fact remain a normal facet of world affairs two centuries hence, as was the case with the Ottoman-Safavid rivalry.

\section{The Empires}

The Ottoman and Safavid empires generally fall into a tripartite group, which includes the Mughal Empire of India, and are referred to as the "gunpowder empires." The gunpowder empire label, initially intended to attribute the empires' successful use of artillery to besiege fortresses, is not entirely accurate. ${ }^{2}$ Rather, the competing dynasties should be thought of as existing in premodern 
times during the gunpowder era. ${ }^{3}$ While the Persian and Turkish empires grew in the Middle East, Portugal explored the oceans of the world, the Renaissance flourished in Italy, the Protestant Reformation emerged in the Germanic states, and Queen Elizabeth I oversaw England's Golden Age.

The Ottoman and Safavid realms possessed fluid similarities in addition to firm differences. They were both imperial theocratic states in which Islam was the primary religion but minority religions flourished. While the Ottoman Empire claimed Sunni primacy and the Safavids espoused Shi' ism, both were empires in the sense that they contained diverse populations with numerous ethnicities, religions, and identities. ${ }^{4}$ In both cases, the non-Muslim population mostly tolerated and lived within the Islamic systems. Domestic opposition, when it occurred, often came from members of the ruling Islamic classes.

Ecologically_an important distinguishing consideration for premodern states - both faced the challenge of overcoming the arid zone limitations (which limited agricultural land and thus minimized the centralized income available for a standing army) placed upon the last major Islamic Empire, the Abbasids. ${ }^{5}$ The Ottomans escaped through their geographic location in Anatolia, while the Safavids overcame such hurdles through the growth of global trade. ${ }^{6}$ Most commonly, this trade took place through the Silk Road or the Persian Gulf. ${ }^{7}$ Both the Ottoman and Safavid rulers also overcame the preexisting revenue collection and distribution challenges of large empires, which "made fiscal decentralization inevitable, thus fostering political disunity," though in different methods and at different times. ${ }^{8}$

Both were militaristic states almost always at war, similar to their European counterparts of the age. The Ottoman and Safavid dynasties claimed their titles from military supremacy — sultan for the Ottomans and shah for the Safavidsin addition to their religious authority as the rightful protectors and authorities of Islam. ' The Safavids merged their Sufi origins with the Shi'i faith, ultimately emerging into "an armed religious order whose legitimacy derived from their dual Sufi and Shi'i religious identities." 10 The Safavids specifically propagated to distinguish themselves from the Ottoman rulers. ${ }^{11}$ The Safavid shah's claim to "quasi-divine status" generated internal instability in Ottoman regions such as central Anatolia and Iraq, which were countered with stronger countermessages of Sunni orthodoxy under the rule of the Ottoman sultans. ${ }^{12}$

In contrast, the Ottoman sultan asserted religious authority as "the most powerful sovereign in the Muslim world and the protector of Islam," part of whose power was derived from the protection of the holy cities of Mecca and Medina in the Arab Peninsula. ${ }^{13}$ Ottoman rulers as early as Murad I (r. 1362-89) referred to themselves as caliph, though the title was used to signify a position of political authority due to their foremost position among Muslim rulers. Only in later centuries would it take on the religious connotations of 
earlier caliphates. ${ }^{14}$ Regardless, the founders of both states portrayed themselves as both Muslim rulers and warriors and depicted themselves as ghazis, "heroic warriors for the faith," while fighting military campaigns in the name of orthodoxy (table 1). ${ }^{15}$

\section{The Ottoman Empire-An Established Power}

The original Ottoman power structure was based on armies of nomadic Turkish cavalry, the sipahis, who fought the sultan's wars. When victorious, they were awarded with land holdings and urban centers to govern and tax as they saw appropriate. This system preserved a provincial power source far away from Istanbul. To counteract the sipahis and move the armies' loyalties closer to the crown, later sultans expanded their Janissary soldiers-slave troops who began as the elite palace guard-into a loyal imperial army who were "superior to any European foot soldiers at the time." 16 The devshirme system supplied young Christian boys from villages in the Caucusus and Balkans to be converted to Islam and serve the sultan as both soldiers and bureaucrats. ${ }^{17}$ Court agents traveled regularly throughout the Ottoman provinces, "conscripting the brightest subject youths for service to the sultan." 18 The robust corps of professional administrators spread throughout the empire and kept detailed records and surveys for decades, perhaps one of the reasons the Ottomans ultimately survived much longer than their Safavid counterparts. ${ }^{19}$

The Ottoman Empire was a system built for war (map 1). The sultan moved his armies back and forth between European and Middle Eastern enemies for centuries, following a similar pattern until the empire's fall after World War I. Istanbul maintained the capability to fight "more or less continuous war" through its elaborate financial and military structures. ${ }^{20}$ As its army grew, so too did its expenses and its requirements for economic growth. In 1527, the Ottoman army had 18,000 Janissaries and artilleryman. By 1670, that number had more than tripled. ${ }^{21}$ The rule of Sultan Suleiman I (r. 1520-66) exemplified Ottoman military prestige with 13 major army campaigns against both the east and the west, which secured Ottoman power for decades. ${ }^{22}$ However, by this period, the ranks of the Janissary corps-perhaps numbering 200,000-were plagued by corruption and swollen with illegal members wishing to benefit from their status in the organization. ${ }^{23}$

\section{The Safavid Challengers}

The Safavids began as a confederacy of nomadic tribes, the Qizilbash, under Isma'il I (r. 1501-24) at the turn of the sixteenth century. The balancing of power inherent in the tribal form of early Safavid government stood in contrast to the established hierarchy of the Ottoman slave-state. ${ }^{24}$ Isma'il I, hailing from a prominent lineage and tracing his ancestors to the origin of Islam, harnessed the 
Table 1. Overview of Ottoman-Safavid rivalry from 1512 to 1639

\begin{tabular}{|c|c|c|c|c|}
\hline Major Ottoman events & Ottoman ruler & Periods & Safavid ruler & Major Safavid events \\
\hline $\begin{array}{l}\text { - Conquest of Egypt, } \\
\text { Levant } \\
\text { - Control of Mecca and } \\
\text { Medina } \\
\text { - First official Sunni } \\
\text { caliph } \\
\text { - Embargo on Safavid } \\
\text { trade }\end{array}$ & $\begin{array}{c}\text { Selim I } \\
(1512-20)\end{array}$ & $\begin{array}{c}1512 \text { to } 1514 \\
\text { Conflict }\end{array}$ & $\begin{array}{c}\text { Ismai'| I } \\
(1501-24)\end{array}$ & $\begin{array}{l}\text { - Safavid dynasty estab- } \\
\text { lished } \\
\text { - Shi'ism adopted } \\
\text { - United Iranian plateau } \\
\text { - Hermit after } 1514\end{array}$ \\
\hline $\begin{array}{l}\text { - Ottoman Golden Age } \\
\text { - Major wars against } \\
\text { Europe } \\
\text { - Annexed North Africa } \\
\text { - Major legislative } \\
\text { reforms }\end{array}$ & $\begin{array}{c}\text { Suleiman the } \\
\text { Magnificent } \\
(1520-66)\end{array}$ & $\begin{array}{l}1515 \text { to } 1531 \\
\text { Peace } \\
1532 \text { to } 1555 \\
\text { Conflict }\end{array}$ & $\begin{array}{l}\text { Tahmasp I } \\
(1524-76)\end{array}$ & $\begin{array}{l}\text { - Civil war after Ismail's } \\
\text { death } \\
\text { - Tribal rivalries in court } \\
\text { - Recruited Caucasians } \\
\text { to counter Qizilbash } \\
\text { influence } \\
\text { - Wars on both borders } \\
\text { - Harbored rebel Otto- } \\
\text { man prince }\end{array}$ \\
\hline $\begin{array}{l}\text { - Anointed after palace } \\
\text { disputes } \\
\text { - Wars against Europe, } \\
\text { Yemen }\end{array}$ & $\begin{array}{c}\text { Selim II } \\
(1566-74)\end{array}$ & $\begin{array}{c}1556 \text { to } 1577 \\
\text { Peace }\end{array}$ & $\begin{array}{c}\text { Ismai'| || } \\
(1576-77)\end{array}$ & $\begin{array}{l}\text { - Imprisoned by father } \\
\text { - Qizilbash domestic } \\
\text { conflict } \\
\text { - Pro-Sunni policies }\end{array}$ \\
\hline $\begin{array}{l}\text { - Killed brothers to } \\
\text { secure rule } \\
\text { - Costly wars in Europe, } \\
\text { Middle East } \\
\text { - Financial difficulties } \\
\text { - Attempted military } \\
\text { reforms } \\
\text { - Rebellion in Anatolia } \\
\text { - Government corrup- } \\
\text { tion }\end{array}$ & $\begin{array}{c}\text { Murad III } \\
(1574-95)\end{array}$ & $\begin{array}{c}1578 \text { to } 1590 \\
\text { Conflict }\end{array}$ & $\begin{array}{c}\text { Khudabanda } \\
(1578-87)\end{array}$ & $\begin{array}{l}\text { - Blind but only heir } \\
\text { - Weak authority, state } \\
\text { factionalism } \\
\text { - Overthrown by son, } \\
\text { Abbas }\end{array}$ \\
\hline $\begin{array}{l}\text { - Killed brothers to } \\
\text { secure rule } \\
\text { - Court rivalries } \\
\text { - Domestic revolts }\end{array}$ & $\begin{array}{l}\text { Mehmed III } \\
(1595-1603)\end{array}$ & $\begin{array}{c}1591 \text { to } 1603 \\
\text { Peace }\end{array}$ & $\begin{array}{c}\text { Abbas the } \\
\text { Great } \\
(1588-1629)\end{array}$ & $\begin{array}{l}\text { - Strongest Safavid } \\
\text { ruler } \\
\text { - Assumed throne while } \\
\text { empire was in chaos } \\
\text { - Qizilbash civil war } \\
\text { - Ottoman and Uzbek } \\
\text { invasions } \\
\text { - Formalized Caucasian } \\
\text { government service } \\
\text { - Reconquered lands } \\
\text { from Ottomans } \\
\text { - Moved capital to } \\
\text { Isfahan, Iran } \\
\text { - Support for art, archi- } \\
\text { tecture } \\
\text { - Killed sons as compet- } \\
\text { itors, grandson became } \\
\text { heir }\end{array}$ \\
\hline $\begin{array}{l}\text { - Wars against Europe } \\
\text { - Wars with House of } \\
\text { Hapsburg, Austria } \\
\text { - Revolts in Anatolia }\end{array}$ & $\begin{array}{l}\text { Ahmed I } \\
(1603-17)\end{array}$ & $\begin{array}{c}1604 \text { to } 1618 \\
\text { Conflict }\end{array}$ & & \\
\hline
\end{tabular}


Vol. 9, No. 2

\begin{tabular}{|c|c|c|c|c|}
\hline $\begin{array}{l}\text { - Competing palace } \\
\text { factions } \\
\text { - Weak ruler, possibly } \\
\text { mentally ill }\end{array}$ & $\begin{array}{c}\text { Mustafa I } \\
(1617-18)\end{array}$ & & & \\
\hline $\begin{array}{l}\text { - Gained throne } \\
\text { through coup } \\
\text { - Imprisoned by Janis- } \\
\text { saries }\end{array}$ & $\begin{array}{c}\text { Osman II } \\
(1618-22)\end{array}$ & $\begin{array}{c}1619 \text { to } 1622 \\
\text { Peace }\end{array}$ & & \\
\hline $\begin{array}{l}\text { - Executed rebels and } \\
\text { opposition } \\
\text { - Remained weak ruler, } \\
\text { no authority } \\
\text { - Political instability } \\
\text { - Janissary and Sipahis } \\
\text { conflict }\end{array}$ & $\begin{array}{l}\text { Mustafa I } \\
(1622-23)\end{array}$ & & & \\
\hline $\begin{array}{l}\text { - Early period of an- } \\
\text { archy } \\
\text { - Revolts in Anatolia } \\
\text { - Revolts by Janissaries } \\
\text { - Strict religious, imperi- } \\
\text { al policies }\end{array}$ & $\begin{array}{l}\text { Murad IV } \\
(1623-40)\end{array}$ & $\begin{array}{c}1623 \text { to } 1639 \\
\text { Conflict }\end{array}$ & $\begin{array}{c}\text { Safi } \\
(1629-42)\end{array}$ & $\begin{array}{l}\cdot \text { Executed rivals } \\
\text { - Little interest in gov- } \\
\text { ernment } \\
\text { - Weakness enticed war }\end{array}$ \\
\hline
\end{tabular}

Source: courtesy of the author.

Map 1. The Ottoman Empire

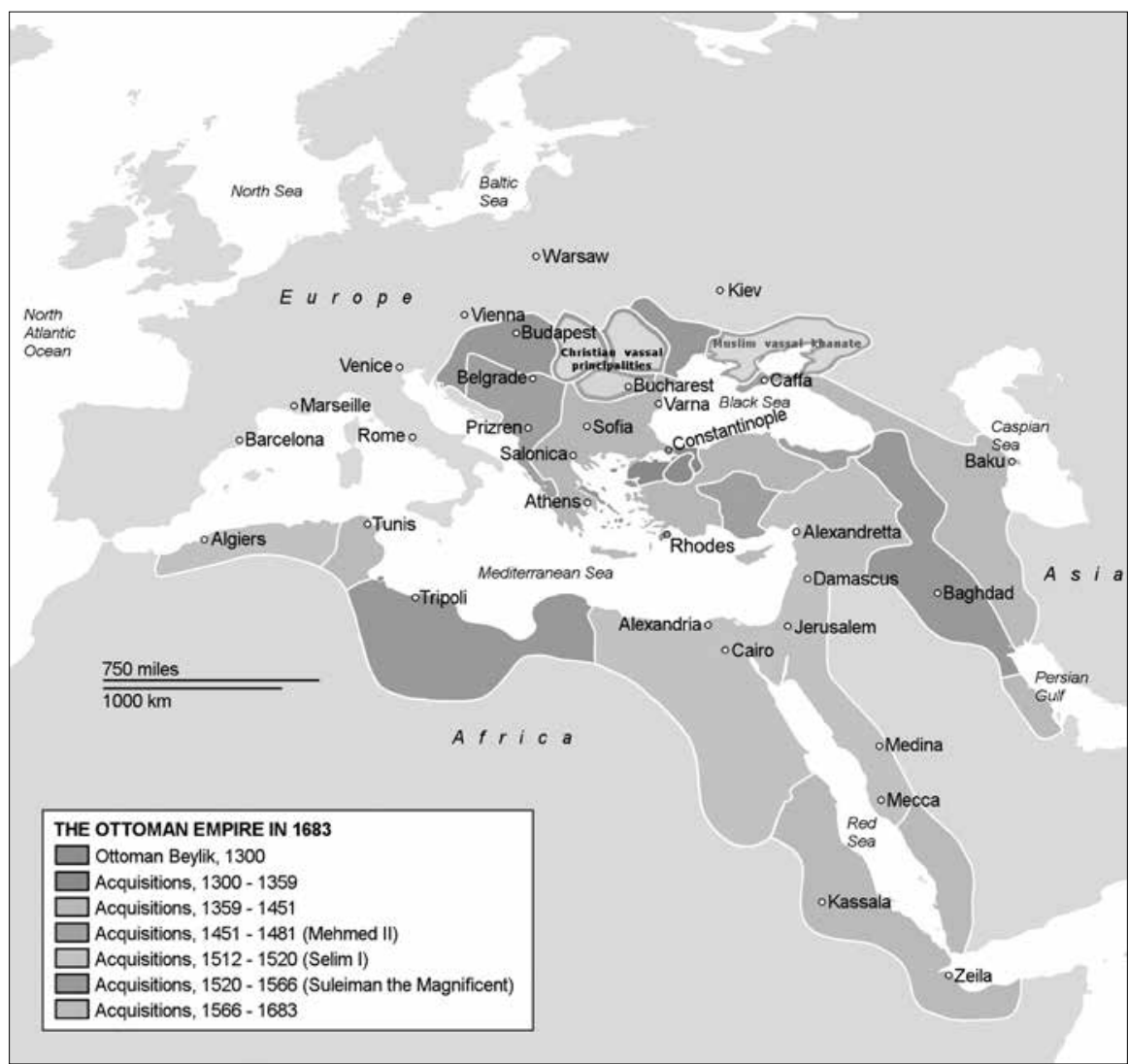

Source: courtesy of Atilim Gunes Baydin, adapted by MCUP. 
growth of Sufism, a rising branch of individualized Sunni Islam, to convert the Persian tribes to Shi' ism and unite them around his personal charisma. Isma'il I led the Qizilbash to conquer Tabriz in 1501, where he founded the Safavid dynasty. ${ }^{25}$ The Safavid imperial structure fused the various cultural histories of the region into a unified dynastic story containing pieces of Assyrian, Babylonian, and Achaemenid influence. ${ }^{26}$ Upon this heritage was placed Shi'a Islam to unify the various ethnicities of the empire, promote the shah's authority, and provide a lineage that was distinctive from the Sunni caliph in Istanbul.

Much of Safavid history, similar to other premodern empires, is a continuous domestic balance of power between the urban cities supported by agriculture and trade against the nomadic tribal communities of the domain's corners, which based their livelihoods on the plunders of war. ${ }^{27}$ The leaders of the Qizilbash provided the empire's early leaders a system around which to structure the empire. Leaders competed for favored positions around the shah and for control of the best cities and lands captured via war. As the empire grew into a more developed form, internal struggles shifted power away from the tribes, with their version of kinship-driven loyalty, to a system of semiprofessional bureaucrats and military officials driven by personal loyalty to the shah. ${ }^{28}$

Perhaps the second most prominent difference after religion between the Ottoman and Safavid states was the Iranian plateau's lack of waterways and port cities to spur trade. ${ }^{29}$ Safavid Persia had "no Paris or London, no Istanbul or Bombay." ${ }^{30}$ Its commercial income relied on dispersed urban areas connected via "precarious" land-based trade routes, many of which went through or terminated in Ottoman territories (map 2). ${ }^{31}$ Modern historians believe the weak economic base of the most distant Safavid regions actually helped the empire survive. With little trade, industry, or agricultural income, local leaders in these areas could never garner sufficient autonomy to break away from the shah's authority. ${ }^{32}$

\section{The Rivalry}

The competition between the empires began early in the sixteenth century and continued for roughly 200 years until the fall of the Safavids. The major struggle for power lasted until 1639 when the Treaty of Zuhab permanently divided Iraq and the greater Mesopotamian region between the Ottomans and Safavids. In 1512, when the Ottomans launched their first invasion of Persian lands, Istanbul was a recognized power with a functioning bureaucratic and military apparatus. The Ottoman Empire had established "institutional maturity" decades prior under Mehmed I (r. 1413-21) and Murad II (r. 1421-44), shortly after the capture of Constantinople in $1453 .{ }^{33}$ The Safavids emerged later but rapidly achieved early success between 1500 and 1514 under Ismai'l I. They would not reach their peak until 1588 with the rise of Abbas I (r. 1588-1629). ${ }^{34}$ 
Map 2. Map of Savafid Empire

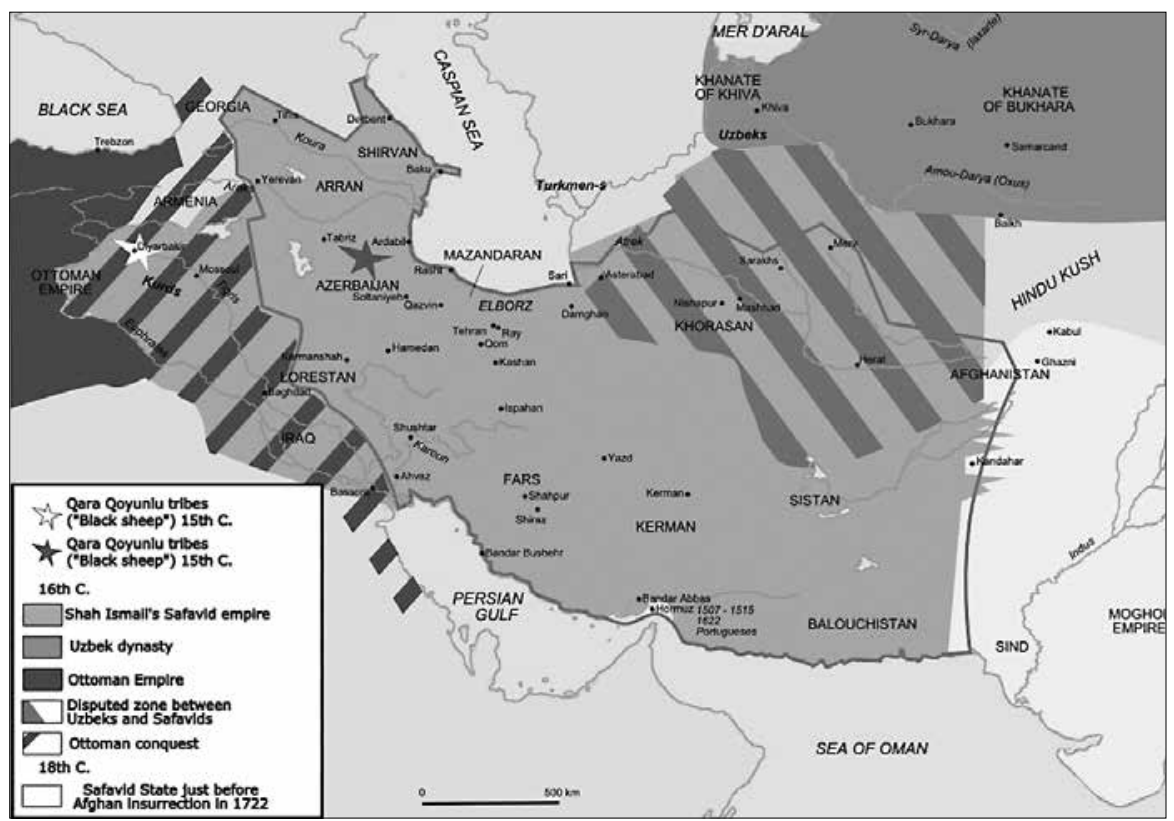

Source: Streudand, Islamic Gunpowder Empires, adapted by MCUP.

The initial success of the Safavids after 1501 stagnated for roughly seven decades throughout the sixteenth century as competing Qizilbash factions vied for imperial favor. While the Safavid leadership stagnated, the Ottoman Empire reached its peak under Sultan Suleiman I (r. 1520-66), now recognized as Suleiman the Magnificent (or the "Lawgiver," as he is known in the Middle East). ${ }^{35}$ Persian power could only reach its full potential later once subsequent leaders had virtually replicated the Ottoman bureaucratic and military systems of importing foreign outsiders to serve only the shah and his state. Even then, the power and unity of Istanbul at the Ottoman Empire's height was never matched by any of the Safavid rulers. ${ }^{36}$ Safavid Persia was always smaller, weaker, and poorer than its Sunni rivals to the west. Some historians even question whether the Safavid dynasty can be called an empire, but Istanbul viewed them as peers. ${ }^{37}$

The rise of the Safavids posed a direct challenge to established Ottoman dominance in Anatolia. ${ }^{38}$ During the late 1400s and early 1500s, Ottoman leadership recognized the threat posed to its rule from the east and took action. Sultan Bayezid II (r. 1481-1512) attempted to mitigate it by banishing Safavid sympathizers to Europe and moved his armies to the eastern frontier on two occasions- 1501 and 1507 - to deter Persian aggression. ${ }^{39}$ Five years later, in 1512, the empires found themselves at war for the first time. 


\section{The Recurrence of War and Peace}

Beginning in the early sixteenth century, the Ottomans and Safavids warred for control over the same border areas driven primarily by religious motivations or strategic concerns for almost two centuries. ${ }^{40}$ The periods of war between Ottoman sultans and the Safavid shahs resembled a regular rhythm for both sides. For Istanbul, always focused more on its campaigns against Budapest or Vienna, war with the Safavids usually followed the establishment of new peace deals with Istanbul's European neighbors. To the east, the Safavid state often found itself in civil war and domestic strife following the deaths of the shah while the Qizilbash factions vied for influence. It was at these moments when the Ottoman armies attacked. The Safavid state then sued for peace to allow time for internal pacification before launching counterattacks against their Sunni neighbor.

The cycle began in 1501 with Ismai'l I's capture of Tabriz near Azerbaijan and adoption of Shi' ism. Competition with the Ottomans commenced immediately due to territorial disputes, urban economic control, and the "nascent nationalism" that developed along dynastic religious differences. ${ }^{41}$ The Ottoman victory in 1514 at Chaldiran and subsequent successes against Egypt and Syria ruined Ismai'l's confidence as a ruler, and he was forced to sue for peace. He went into seclusion for the next decade until his death in $1524 .{ }^{42}$ Political chaos within the Safavid regions followed, and Istanbul, secure in the west from a new treaty with Hungary, exploited the situation to march its army against Persia. The Janissaries captured Baghdad in 1534 "with no resistance," and within two years added the main holdings of eastern Anatolia back to the Sultan's domain. ${ }^{43}$

War continued for 20 years until 1555 as the Ottoman armies gained further territory throughout Mesopotamia until the new shah sued for peace to stabilize Persia from internal civil war and Uzbek incursions in the east. ${ }^{44}$ Shah Tahmasp I (r. 1524-76) used the peace to reduce the power of rival tribal leaders and consolidate his hold over the empire. Due to the personal nature of his rule, though, the existing constituencies and centers of authority were "voided" with his death. ${ }^{45}$ Unfortunately for Persia, the Ottomans were again free to attack east due to stalemates in the Mediterranean and truces with the Hapsburgs. ${ }^{46}$ In 1585 , Ottoman armies captured the old Safavid capital of Tabriz and secured control over most of the Caucasus and Azerbaijan, both of which were economically important provinces. ${ }^{47}$

Shah Abbas I rose to the Safavid throne in 1588 following a decade of instability and Ottoman victories. He sued for peace with Istanbul to gain time, strengthen Persia internally, and combat the Uzbek incursions still plaguing his eastern border. Abbas modernized and reorganized the Safavid military to provide an effective counter to the Ottoman forces and ultimately pushed them 
out of Azerbaijan and the Caucusus between 1603 and 1605. The recapture of Tabriz in 1605 unofficially ended this series of wars until peace treaties could be solidified in $1618 .^{48}$

During this period, the Safavids posed their greatest challenge to Istanbul, and the Ottoman sultan Osman II (r. 1618-22) tried to institute major transformations in the military and bureaucracy, such as eliminating the Janissaries. The endeavor failed remarkably. The Janissaries deposed Osman and placed his brother Mustafa on the throne (now referred to as "Mustafa the Mad" due to reports of mental instability), a rebellion broke out in Anatolia, and Istanbul "fell into anarchy." ${ }^{49}$ Shah Abbas took advantage of the domestic Ottoman instability, just as his own empire's internal weaknesses were previously exploited. He achieved additional successes a few years later in 1623 with the capture of most of Kurdistan and Iraq, including a successful defense of Baghdad against the Ottoman army. ${ }^{50}$ By the end of his reign, Abbas's successes included a restructured state, a loyal army, an expanded economy, and a magnified imperial power, which he extended from his capital in Isfahan. ${ }^{51}$ Many historians agree that the pinnacle of Safavid Persia — the closest it came to a golden age — ended after the death of Abbas. ${ }^{52}$

War between the two powers continued until the nineteenth century, though without any major realignments like the 1639 peace treaty. This regularity of battle was not inevitable. For example, the Ottomans were consistently reluctant to launch military campaigns to the eastern side of its empire. Logistical concerns and the harsh environment of Mesopotamia and the greater Iranian plateau meant that Ottoman generals preferred to operate in the empire's western frontier "where they would find abundant food and water." 53 The Ottomans excelled at siege warfare, but such knowledge was near worthless on the Persian Steppe with few fortresses and an enemy composed of Turkic cavalrymen. ${ }^{54}$ Peace was welcomed at times, even by the victorious side. While the Safavids viewed the Treaty of Amasya in 1555 as an embarrassing loss, these difficult campaigning conditions in conjunction with "war-weariness" in Anatolia meant the Ottomans were willing to sign the treaty instead of pursuing further gains. ${ }^{55}$

Despite efforts to the contrary, wars were launched for any number of varied reasons, including religious conquest, economic gains, national glory, or court personalities. Peace treaties failed to stem the cycle as each new government brought new desires to increase national pride and overcome previous wrongs. These same themes and cycles of war appear in other cases of great power rivalry. England and France fought recurring wars for centuries and conflict between the Soviet Union and United States, while never directly expressed, broke out in the form of proxy wars and near-war experiences on multiple occasions. Additionally, while the Safavids and Ottomans fought repeatedly over 
the same regions (Azerbaijan, Iraq, the Caucasus), so too could multiple periods of conflict break out between the United States and China over the variety of conflicting interests in the Asia-Pacific region, such as North Korea, Taiwan, and the South China Sea.

\section{Domestic Unity and International Competition}

Competition between cultures has existed since the first communal organizing of mankind and has perhaps led to more conflict than any other matter. Culture is inherently unique to an ethnicity, country, religion, or people that can spread and be exported but tends to remain tied to one place of origin. The competition between Ottoman Sunnism and Safavid Shi'ism was more than a religious or cultural difference. For the Ottomans, Sunni Islam-the only Islam-was a source of authority and worldly order. ${ }^{56}$ The rise of Shi' ism to the east constituted not only a heretical religion and rival culture but a direct and contradictory threat to the legitimacy of the sultan's rule, much the same as the political threat Protestantism posed to Roman Catholicism in Europe. ${ }^{57}$ At the founding of both empires, religious sentiments tended to be superficial and rulers were more tolerant of heterodoxy within their lands. Later administrations on both sides resorted to stronger religious claims to unify their ethnically diverse lands, which continued to fracture and surely contributed to the downturn of relations between the two powers. ${ }^{58}$ These "religious undertones" seeped into the fighting as decades passed. ${ }^{59}$ Both rulers continued raising new armies and fighting new wars to gain glory for the state and to overcome previous religious or political humiliations.

The increased antagonism between different cultural identities highlights the often-unintended circumstance of increased internal unity leading to external competition. Both the shah and sultan's portrayal of themselves as defenders of the faith and the Muslim people increased the loyalty of their populations while simultaneously moving their empires closer to conflict. Especially in Persia where the deaths of most shahs brought domestic strife and civil war, religious homogeneity was the best means to unify the various competing groups. Each round of renewed Shi'a assertions, however, brought more trouble with the Ottomans because cultural competition often contributed to military competition. For instance, the Safavids looked toward Iraq for its religious importance as "the object of pilgrimage" for the Shi' a saints. ${ }^{60}$ Baghdad and Mesopotamia thus became a prize to be won through war. The shahs viewed Iraq as "part of their rightful heritage." ${ }^{61}$ The cultural importance of areas like an-Najaf compounded the economic incentive for conquest and helped motivate the shahs to launch multiple campaigns into the area.

Nationalistic and cultural differences between great powers today often appear minimized due to globalism, social media, and international trade. But 
even during this premodern period, cultural overlaps between the Ottoman and Safavid courts, such as the fact that Persian was the diplomatic language of the Ottomans even during times of war, showcase that differences often outweigh similarities when interests clash and rivalries ensue. ${ }^{62}$ Leaders emphasizing the economic dependence between China and the United States may find it difficult to restrict growing passions of nationalism and patriotic pride if, or when, the two compete.

\section{Economic Cooperation, Economic Competition}

Imperial finances were a regular focus of domestic concerns and wartime competition. It comes as no surprise that the ability to collect, manage, and disperse funds challenged both the sultan and shah in the sixteenth and seventeenth centuries, just as it does for the twenty-first century nation-state. Both empires found their economic interests overlapping at times, such as with the silk trade. Regardless of mutual benefits, control of valuable economic regions like the Caucasus and eastern Anatolia pushed both sides to multiple wars. Without accurate accounting records, it remains difficult to discern whether these endeavors — when successful — were worth the cost relative to the logistical expenses of campaigning with premodern armies for multiple years. It is doubtful, though, as the cost of military expeditions occurred frequently in the discussions among imperial advisors and campaigns, such as the 1590s fighting in the Caucasus and Azerbaijan, which drained the Ottoman treasury. ${ }^{63}$ Plunder from the war was scarce and provincial tax yields from the conquered territories was inadequate to sustain the required military garrisons. ${ }^{64}$ On another occasion, the recapture of Baghdad by the Ottomans forced the Safavids to impose serious reductions in expenses and heavy taxation. ${ }^{65}$ It appears more likely that the preconceived notion of financial gains from these regions led to war rather than the actual revenue recovered.

The Ottoman and Safavid rulers understood the importance of and relied on the results of successful economic endeavors. The Ottomans depended on levies from wealthy regions and the taxes from shipments of oriental goods like silk and cotton to Europe. ${ }^{66}$ They benefited from the occupation of Tabriz by controlling all the overland silk trade routes between Persia and the Mediterranean. ${ }^{67}$ In both empires, religious and civic centers were doubly used as markets and commercial hubs to link the leaders' religious authority to economic prosperity, thus helping to restrict opposition. The use of the waqf, a religious charity often supported from nearby stores, was the "conscious result of imperial commitment to stimulating the commercial exchange." ${ }^{68}$ Both empires emphasized the connection between trade, economic prosperity, and the ruler's authority to govern, especially due to the shortage of farming areas in the greater Middle East. For instance, after capturing Istanbul in 1453, the Ottoman 
ruler Mehmed II guaranteed the safety of the non-Muslim commercial leaders due to their importance in Mediterranean trade.

In the Safavid regions, Abbas I founded an empire-wide market system to meet the needs of "an impoverished economy, a fragile state, and an unreliable military system." ${ }^{69}$ Abbas, like the Ottoman rulers, relied on minority communities such as the Armenians to empower his economy. The "pragmatic tolerance of non-Muslim commercial communities" was not only endured but promoted by both empires alike due to economic realities. ${ }^{70}$ In Persia, the reshaping of a widespread economy on minority-driven trade helped lead to the peak of Safavid power under Abbas.

Four premises stand out from the Ottoman-Safavid economic relationship with possible contemporary relevance. The first is that competitive great powers will likely enter into conflict-violent or not-over perceived economic gain rather than actual economic gain. Second is the significance and tolerance of minority communities due to their importance to the state's economic functioning. The third is recurring competition over prosperous and strategically important regions, specifically eastern Anatolia and modern-day Iraq. ${ }^{71}$ Iraq's southernmost Basra Province could be used for commercial expansion into the Persian Gulf and maritime trade to the Indian Ocean, while the routes through northern Iraq, such as Mosul, facilitated trade between the Middle East and the Mediterranean. ${ }^{72}$

Finally, despite wars and competition between the two sides, both the Ottomans and Safavids were economically linked through international trade routes. The silk trade "represented Iran's [Persia's] principal and most valuable export" and was primarily shipped through Ottoman routes to Europe. ${ }^{73}$ The silk industry was "critical" to both empires and mentioned explicitly in treaty arrangements. ${ }^{74}$ Unfortunately, despite economic interdependence and the high costs of war, both rulers were willing to go to war for financial gains. The contemporary analogies are significant. Many experts argue that the economic interweaving of global markets, especially between such powers as China and the United States, will serve as a strong inhibitor toward violent conflict. Westerndriven organizations, such as the World Bank and World Trade Organization may soon find their status fragile against Chinese-led competitors like the Asian Infrastructure Investment Bank and the One Belt, One Road initiative. Geographic chokepoints like the Straits of Malacca carry international power for those who control them. Hopes for peace spurred on by economic prosperity may not pan out.

\section{Third-Party Alliances and Diplomacy}

Diplomacy played a major role in the abilities of both capitals to manage their empires. Wars were expensive, logistically challenging, and far from a guar- 
anteed outcome. Diplomats and political arrangements helped control the most-distant areas where imperial military power was weakest. The geographic distance between Istanbul and its governors in Iraq led to minimal involvement or support for the defense of the Mesopotamian frontier. ${ }^{75}$ Local leaders resorted to "whatever arrangements they could to hold the borderlands in the face of Iranian [Persian] hostility." N6 Naturally, such precarious conditions in the corners of the empires meant that local strongmen were open to negotiation over their loyalties. The allegiances of third-party tribes and communities in the frontier zones were often available to the highest bidder or the most immediate threat.

The wealth of areas such as Baghdad and Basra meant that the sultan frequently found himself negotiating with subordinates for their allegiance. ${ }^{77}$ After their 1514 victory at Chaldiran, the Ottoman sultan preferred diplomacy to secure his alliances with the Kurdish chieftains in eastern Anatolia. ${ }^{78}$ Many subsequent Ottoman diplomatic missions worked to secure the loyalty of Kurdish chieftains and were improved by sending loyal Kurdish nobles to parlay with the provinces. ${ }^{79}$ This tactic was unique to the Kurds. While Istanbul used military force to control most of its frontier holdings, it preferred diplomacy and familial relations to secure Kurdistan. ${ }^{80}$

The loose hold on power by central authorities meant that inconsistent commitment from the frontier zones could lead to war and required constant supervision. The initial Ottoman incursion against Persia in 1512 was launched partially in support of a local leader who preferred Istanbul to Tabriz. ${ }^{81}$ One of the greatest crises for Safavid rule came during the Ottoman invasion of 153334 when the threat was compounded by the emergence of rebels in Iraq and attempts to poison the shah and replace him. ${ }^{82}$ On another occasion, a main cause of the 1578 conflict was how the Kurdish factions played both empires against each other. ${ }^{83}$

Diplomacy and communication was the norm between the two empires during times of peace. Most often, such overtures took the form of Safavid rulers sending delegations to Istanbul to preserve fragile treaties and reduce the risk of renewed conflict. In 1567, Persia sent a massive delegation of diplomats and gifts to the newly crowned sultan to foster good relations. ${ }^{84}$ An ensemble of 320 men and 400 merchants made the journey to Istanbul to congratulate Selim on his ascension and a similar retinue traveled a decade later for Murad III's coronation. ${ }^{85}$

Relations with Europe played a part during the Ottoman-Safavid rivalry regarding international trade and outlying regions. The Portuguese traded silk through the Straits of Hormuz beginning in 1543, and the English and Dutch merchant trading companies sought out trading routes along the maritime fringes of the empires to gain monopolies on goods from the east. ${ }^{86}$ Iranian silk 
producers attempted in the late sixteenth century to redirect trade away from the Ottoman-controlled ports on the Mediterranean and instead trade through European partners. Increased economic ties with Europe then led to overtures for military alliances during times of war. For example, the Ottomans sought European partners via British diplomats and even took part in a joint maritime operation in 1622 with the Portuguese in Hormuz to garner favor. ${ }^{87}$ Diplomatic missions to Paris also created an alliance between the Ottoman Empire and France for nearly the entire sixteenth century. ${ }^{88}$

Modern great powers should appreciate the need for continuous diplomatic efforts, even if their success is erratic. Competition for the Asia-Pacific region will only continue and both China and the United States require allies to meet their national goals. It is likely that some third-party nations will appeal to both sides and become areas of competition as they did during the Cold War. Such a situation should be expected and managed to reduce the possibility of war.

\section{Domestic Competition}

There is no shortage of historical examples of outside interference in the domestic matters of a state, and the Ottoman-Safavid rivalry is no exception. Both competitors often intruded in the others' domestic affairs. For seven years prior to the 1555 peace treaty, the Ottoman ruler Suleiman twice supported rival claimants to the Safavid throne. ${ }^{89}$ Suleiman's own son Bayezid attempted to mount a rebellion and overthrow his father from Persia until the Safavids deemed his protection too risky and returned him to authorities in Istanbul. ${ }^{90}$ Domestic inference contributed to war just as cultural differences and economic interference did. Safavid protection of Anatolian tribal authorities wanted by the Ottoman sultan sparked the rivals' first war in 1512. ${ }^{91}$ The Ottoman sultan's orders for local frontier leaders to conduct border raids into Safavid territories led to the breakout of war in $1578 .{ }^{92}$

A second domestic matter contributing to war was the competition among those around the throne for power and favor. In Istanbul, while the sultan's authority was supreme, the grand vizier oversaw most of the state functions with assistance from other advisors. ${ }^{93}$ For most of the Ottoman-Safavid rivalry, two competing factions of ministers served the sultan as advisors. Istanbul's "enduring strategic rivalries" led to some advisors arguing that Europe and Hungary should be the empire's primary focus, while others demanded wars against the Safavids in the east. ${ }^{94}$ For example, the Ottoman attacks in 1576 after the shah's death were not a "foregone conclusion but the outcome of a set of specific political circumstances at the court in Istanbul." ${ }^{95}$ As reports from local Turkish rulers in eastern Anatolia documented the internal disorder within Safavid lands, a faction of ministers argued that attacking Persia would bring more wealth and glory to the empire than fighting in Europe. ${ }^{96}$ 
Domestic opposition groups could take the form of military leadership, and internal military opposition could force a leader's hand. After victory in 1514, Selim I had the opportunity to press his offensive and secure additional gains over the Safavids. However, his army, after nearly four years in the field, refused to continue. The political desires of the dynasty met their end at the overstretched capabilities of its army. ${ }^{97}$

Domestic instability in either capital enticed action by the other, and the Ottoman armies took frequent advantage of Safavid internal weaknesses to secure military victories. Ismail I's reign after 1514 was fragile and depended on the internal balancing of Qizilbash tribes. ${ }^{98}$ Subsequent shahs also had to delicately balance the competing tribal factions to maintain domestic harmony. Multiple Persian leaders attempted to reform the domestic power balance to overcome such discrepancies. In 1532, Tahmasp removed tribal leaders and appointed scholars to bring steadiness and coherence to a bureaucracy plagued with rivalry. ${ }^{99}$ The continued growth of competing domestic groups during the 1560 s resulted in division and civil war after his death in $1576 .{ }^{100}$ One faction of Qizilbash placed Tahmasp's son, Isma'il II, on the throne to exert their influence over the state. Strife ensued and Isma'il II died only a year later from opium abuse, leading to further disunity. ${ }^{101}$

Persian insecurity again led to subsequent Ottoman invasions and Abbas's desperate peace treaty in $1590 .^{102}$ The cost of peace was high: the Safavids gave up the valuable provinces of Azerbaijan and Iraq to focus on their internal stability. ${ }^{103}$ Abbas then put his full attention into formalizing the system of placing Georgian and Caucusian Muslim converts into the military and bureaucratic structure to counteract the tribes. With a capable army and bureaucracy, he recaptured lost territory and reunified the empire. However, the decision to strip power from the Qizilbash led to further domestic fracturing when tribal elites reasserted their dominance after his death. ${ }^{104}$

The Safavid power structure remained less hierarchical and more impermanent than the Ottomans. Tribal factions always played a major role in Persian political arrangements. For example, Abbas only rose to power in 1587 due to the resurgence of a specific tribe called the Ustajlu who other tribes rallied around. ${ }^{105}$ The throne's tenuous hold on power meant that drastic steps were taken to secure authority. During 1631 and 1632, while Ottoman armies and Uzbek invasions ravaged the Safavid frontier, rumors about coups and schemes to depose the shah flowed abundantly. The shah and his advisors took drastic actions to secure his rule through the elimination of any potential claimants to the crown. ${ }^{106}$

Such conditions were not unique to Persia. Ottoman sultans frequently killed or banished competitors to their rule. Selim I killed as many as 40,000 Persian sympathizers upon his assumption to the throne in $1512 .{ }^{107}$ The death 
of Ahmed I in 1617 initiated the "times of troubles" as rival Turkish groups competed to put their preferred heir on the Ottoman throne. Years of reform efforts failed and destabilized the empire. In 1623, to "prevent the disintegration of the Empire," enough power brokers agreed to dethrone the sultan, anoint the 12-year old Murad IV, and buy the loyalty of rebelling Janissary groups. ${ }^{108}$ Another telling example comes from the Battle of Lepanto in 1571 when a combined European fleet destroyed the Ottoman navy in the Mediterranean. The Turkish leaders brought their entire personal fortunes on the expedition to avoid confiscation from the sultan. ${ }^{109}$ It was all lost with the destruction of their vessels during the battle.

Competition between domestic groups may push a leader toward war when it is against a nation's best interest. In both the structured Ottoman government and the looser Safavid arrangements, the throne's rule was far from absolute, and disagreements by advisors contributed to the outbreak of conflict. Finally, domestic instability can entice a rival to act.

\section{The Futility and Finality of Superpower Conflict}

The wars between the Ottomans and Safavids should be viewed as a regular cycle of violence to pursue domestic desires rather than a prolonged existential conflict. Wars broke out for one or multiple reasons: imperial glory, economic pursuits, religious crusades, geographic control, or political competition. On multiple occasions, war was initiated due to perceived disgraces of previous peace treaties. One motivation for Abbas to strengthen the military and go to war in the early seventeenth century was the "humiliating" arrangement of 1590. ${ }^{110}$ Each treaty - 1514, 1555, 1590, 1618, and even 1639-failed to stem the cycle of war between the two empires, despite their mutually beneficial economies, individual domestic concerns, and other external rivals (the Hapsburgs and the Uzbeks).

Perhaps the greatest lesson from the Ottoman-Safavid rivalry is the lasting impact it had on the regions and persons where the competition took place. The rulers never imposed substantial or lasting impact on the other. Beginning in 1514 with the initial Ottoman victory, both rivals "accustomed themselves to centuries of intermittent, wasteful, and unwinnable frontier wars," which focused on territories such as Iraq. ${ }^{111}$ Neither empire fell due to fighting with the other. Instead, the effects from the rivalry are still witnessed today in the divisions of people and geography.

The final division between Sunni and Shia lands solidified the Middle Eastern boundary between Ottoman and Persian rulers. The impact upon Persia from the Safavid rulers stands tallest. Despite a lack of military success against its Ottoman neighbors, the Safavid Empire brought two lasting impacts to the Iranian plateau. The first was unity. The Arab conquests and Mongol invasions 
shattered the political cohesion of the region; but under the Safavid reign, weak and disparate provinces were replaced by a "united realm of Iran, more or less within its present frontiers." 112 The second lasting contribution of the Safavids was the Shia identity, strengthened during each series of wars and domestic unrest. ${ }^{113}$ Modern-day Persia, and later Iran, with its characteristic Shia prominence and discrete Persian heritage, emerged under the Safavid rulers as a "separate, different and distinctive element within Islam." 114 The same effects occurred in Ottoman lands where Sunni Islam persists as the predominant religion today.

Major hostilities between the two sides concluded in 1638 with the Ottoman recapture of Baghdad. In repetitive fashion, domestic concerns within Safavid lands spurred on by weak monarchs and competitive ministers forced the shah to relinquish his claims to Iraq permanently. ${ }^{115}$ The Safavids paid a great price to secure their dynastic existence, but the impact from the 1639 Treaty of Zuhab was immediate. The Persian economy recovered from the opening of Levantine ports and the export of silk regained its former vitality. Both sides reemphasized their religious credentials in the form of shrines, mosques, and proclamations. ${ }^{116}$ The religious and political geography of the greater Middle East remains unchanged since the Ottoman-Safavid period. Eastern Anatolia, often fought over but never controlled by the Safavids, is still controlled by Istanbul. Premodern capitals like Mosul, Damascus, and Baghdad emerged firmly into the Arab-Ottoman heritage they embrace today, despite their substantial Shia communities.

The two empires survived for centuries after the treaty. The decline of the Ottoman Empire was long and drawn out. Continuous reform efforts kept Istanbul as an international power up until its final dissolution in 1922. Its longevity relative to its Shia neighbor can be at least partially attributed to the well-organized provincial structure and capable administrative functions that made its control more permanent. ${ }^{117}$ The caliph's religious authority certainly played a role in regime survival as well.

The Ottoman decline is partially attributable to the decline in quality of sultans to guide it. While early sultans rose to power by proving themselves adept military and political leaders in the Ottoman provinces, the later practice of palace-protected sons ascending to the throne lessened the quality of royal leaders. ${ }^{118}$ The devshirme class of converted non-Turkish bureaucrats who ran the empire eventually "broke up into conflicting political factions," after which "the Ruling Class fell into a maze of petty struggles." 119 Additional economic and population changes, such as the lack of financial and industrial development that occurred in Europe, accelerated the end of the Ottomans.

Part of the Safavid survival until the mid-nineteenth century can be attributed to factors beyond the state's control. The heart of Safavid Persia was 
geographically isolated, especially after the relocation of the capital from Tabriz near the Ottoman border. Potential capturing forces, such as the Ottoman armies, lacked the funding, willpower, or capabilities to mount such difficult missions. The relative poverty of the Safavid territory increased the difficulty of rival domestic leaders to establish centers of power to compete with the shah, and a lack of established communication lines meant coordination between groups to oppose him faced immense hurdles. ${ }^{120}$ Luck played a secondary role: due to the Safavid's internal weaknesses and constant foreign threats, it remains "remarkable that the Safavid polity survived at all." ${ }^{121}$

\section{Conclusions}

The Thucydides's Trap model is used to compare examples of rising powers and established powers to examine the conditions that can lead to war and those that can help avoid it. The purpose of such a study is not to provide prescriptive solutions to policy makers for implementation or to diagnose the exact conditions that lead to war. Rather, it is to provide recommendations for managing a relationship, identify potential sources of conflict, and avoid a catastrophic aftermath.

The Ottoman-Safavid conflict presents these six ideas for the possibilities of great-power conflict. Alternating periods of conflict may break out between the two states. When they occur, they need not become existential crises but can remain as limited actions to better protect the stability of the international political and economic systems. International attempts to limit war may not be able to overcome the will of domestic populations or interest groups in either nation, especially during times of increased nationalism. A changing political scenery regarding alliances and third-party nations should be expected and mitigated through extensive and continuous diplomacy. As Allison states, "To escape Thucydides's Trap, we must be willing to think the unthinkable-and imagine the unimaginable. Avoiding Thucydides's Trap in this case will require nothing less than bending the arc of history." 122 Fortunately, the arc of history, like the Ottoman and Safavid dynasties, is enduring, protracted, and adaptable.

\section{Notes}

1. "Thucydide's Trap," Harvard Kennedy School, Belfer Center for Science and International Affairs, accessed 27 June 2018. Thucydides's Trap, as a theory of great power relations, is debated between international relations scholars with some prominent academics rejecting its relevance or claiming its misinterpretation in modern times. It is used here as a reference point with which to frame the discussion due to the popularity of the argument. This article does not argue in favor of the model; rather, it attempts to frame a former great power rivalry in a similar context.

2. Douglas E. Streusand, Islamic Gunpowder Empires: Ottomans, Safavids, and Mughals (Boulder, CO: Westview Press, 2011), 2-3.

3. Streusand, Islamic Gunpowder Empires.

4. Stephen F. Dale, The Muslim Empires of the Ottomans, Safavids, and Mughals (Cambridge, 
UK: Cambridge University Press, 2010), 3, https://doi.org/10.1017/CBO9780511 818646.

5. Streusand, Islamic Gunpowder Empires, 18.

6. Streusand, Islamic Gunpowder Empires, 292.

7. John J. Curry, review of Islamic Gunpowder Empires: Ottomans, Safavids, and Mughals, by Douglas E. Streusand, Digest of Middle East Studies 20, no. 2 (Fall 2011): 353, https://doi.org/10.1111/j.1949-3606.2011.00114.x.

8. Streusand, Islamic Gunpowder Empires, 3.

9. P. M. Holt, Ann K. S. Lambton, and Bernard Lewis, eds, The Cambridge History of Islam, vol. 1A (Cambridge, UK: Cambridge University Press), 320-21.

10. Dale, The Muslim Empires of the Ottomans, Safavids, and Mughals, 52.

11. R. M. Savory, "Safavid Persia," in The Cambridge History, 394.

12. Colin Imber, "The Ottoman Empire (Tenth/Sixteenth Century)," in The New Cambridge History of Islam, vol. 2, The Western Islamic World, Eleventh to Eighteenth Centuries, ed. Maribel Fierro (Cambridge, UK: Cambridge University Press), 333-34.

13. Holt, Lambton, and Lewis, eds., The Cambridge History of Islam, 320.

14. Holt, Lambton, and Lewis, eds., The Cambridge History of Islam, 320-23.

15. Dale, The Muslim Empires of the Ottomans, Safavids, and Mughals, 49-50.

16. Dale, The Muslim Empires of the Ottomans, Safavids, and Mughals, 58.

17. Stanford Shaw, History of the Ottoman Empire and Modern Turkey, vol. I, Empire of the Gazis: The Rise and Decline of the Ottoman Empire, 1280-1808 (Cambridge, UK: Cambridge University Press), 113-14.

18. Shaw, Empire of the Gazis, 114.

19. Curry, review of Islamic Gunpowder Empires, 353.

20. Andrew Wheatcroft, "Islam's Final Push: The Ottomans versus the Hapsburgs," in Great Strategic Rivalries: From the Classical World to the Cold War, ed. James G. Lacey (Oxford: Oxford University Press, 2016), 243.

21. Wheatcroft, "Islam's Final Push," 244.

22. Shaw, Empire of the Gazis, 87.

23. Shaw, Empire of the Gazis, 171.

24. Dale, The Muslim Empires of the Ottomans, Safavids, and Mughals, 59-60.

25. Dale, The Muslim Empires of the Ottomans, Safavids, and Mughals, 49.

26. Rudi Matthee, "Relations between the Center and the Periphery in Safavid Iran: The Western Borderland v. the Eastern Frontier Zone," Historian 77, no. 3 (Fall 2015): 431, https://doi.org/10.1111/hisn.12068.

27. Matthee, "Relations between the Center and the Periphery in Safavid Iran," 433.

28. Matthee, "Relations between the Center and the Periphery in Safavid Iran," 434.

29. Matthee, "Relations between the Center and the Periphery in Safavid Iran," 437.

30. Matthee, "Relations between the Center and the Periphery in Safavid Iran," 438.

31. Matthee, "Relations between the Center and the Periphery in Safavid Iran," 438.

32. Matthee, "Relations between the Center and the Periphery in Safavid Iran," 440.

33. Streusand, Islamic Gunpowder Empires, 3.

34. Streusand, Islamic Gunpowder Empires, 3.

35. Dale, The Muslim Empires of the Ottomans, Safavids, and Mughals, 180.

36. Dale, The Muslim Empires of the Ottomans, Safavids, and Mughals, 180.

37. Streusand, Islamic Gunpowder Empires, 135.

38. Andrew J. Newman, Safavid Iran: Rebirth of a Persian Empire (London: I. B. Tauris, 2006), 21.

39. Streusand, Islamic Gunpowder Empires, 45.

40. Kenneth W. Harl, "Rome's Greatest Foe: Rome versus Parthia and Sassanid Persia," in Great Strategic Rivalries, 150.

41. Sandra Mackey, The Iranians: Persia, Islam and the Soul of a Nation (New York: Dutton Books, 1996), 83.

42. Mackey, The Iranians, 83-85.

43. Colin Imber, The Ottoman Empire, 1300-1650: The Structure of Power (London: Palgrave, 2002), 51-53. 
44. Newman, Safavid Iran, 28.

45. Newman, Safavid Iran, 41.

46. Newman, Safavid Iran, 43.

47. Streusand, Islamic Gunpowder Empires, 52.

48. Streusand, Islamic Gunpowder Empires, 55.

49. Streusand, Islamic Gunpowder Empires, 55.

50. Streusand, Islamic Gunpowder Empires, 153.

51. Dale, The Muslim Empires of the Ottomans, Safavids, and Mughals, 95.

52. Streusand, Islamic Gunpowder Empires, 153.

53. Rudi Matthee, "The Ottoman-Safavid War of 986-998/1578-90: Motives and Causes," Special Section on Ottoman-Persian Historical Exchanges, International Journal of Turkish Studies 20, nos. 1 and 2 (Fall 2014): 9.

54. $\quad$ Matthee, "The Ottoman-Safavid War of 986-998/1578-90," 9.

55. Matthee, "The Ottoman-Safavid War of 986-998/1578-90," 9.

56. William R. Polk, Understanding Iraq (New York: Harper Perennial, 2005), 59.

57. Polk, Understanding Iraq, 59.

58. Matthee, "The Ottoman-Safavid War of 986-998/1578-90," 10.

59. Albert Hourani, A History of the Arab Peoples (Cambridge, MA: Belknap Press, an imprint of Harvard University Press, 1991), 221.

60. Polk, Understanding Iraq, 59.

61. Nabil Al-Tikriti, "Ottoman Iraq," Journal of the Historical Society 7, no. 2 (June 2007): 201, https://doi.org/10.1111/j.1540-5923.2007.00214.x.

62. Robert D. Kaplan, The Revenge of Geography: What the Map Tells Us about Coming Conflicts and the Battle against Fate (New York: Random House, 2012), 300.

63. Imber, The Ottoman Empire, 1300-1650, 66.

64. Imber, The Ottoman Empire, 1300-1650, 66.

65. Newman, Safavid Iran, 76.

66. Hanson, Carnage and Culture, 263.

67. Dale, The Muslim Empires of the Ottomans, Safavids, and Mughals, 115.

68. Stephen F. Dale, "Empires and Emporia: Palace, Mosque, Market, and Tomb in Istanbul, Isfahan, Agra, and Delhi," Journal of the Economic and Social History of the Orient 53, nos. 1 and 2 (2010): 212, https://doi.org/10.1163/002249910X1257396324403.

69. Dale, "Empires and Emporia," 213-20.

70. Dale, "Empires and Emporia," 225-26.

71. Al-Tikriti, "Ottoman Iraq," 201.

72. Al-Tikriti, "Ottoman Iraq," 201.

73. Dale, The Muslim Empires of the Ottomans, Safavids, and Mughals, 121.

74. Dale, The Muslim Empires of the Ottomans, Safavids, and Mughals, 121-23.

75. Matthee, "The Ottoman-Safavid War of 986-998/1578-90," 19.

76. Al-Tikriti, "Ottoman Iraq," 203.

77. Al-Tikriti, "Ottoman Iraq," 204.

78. Dale, The Muslim Empires of the Ottomans, Safavids, and Mughals, 178.

79. Imber, The Ottoman Empire, 1300-1650, 45.

80. Hourani, A History of the Arab Peoples, 227.

81. Imber, The Ottoman Empire, 1300-1650, 45.

82. Streusand, Islamic Gunpowder Empires, 148.

83. Matthee, "The Ottoman-Safavid War of 986-998/1578-90," 17.

84. Newman, Safavid Iran, 39.

85. Matthee, "The Ottoman-Safavid War of 986-998/1578-90," 8-9.

86. Newman, Safavid Iran, 61.

87. Newman, Safavid Iran, 61.

88. Hanson, Carnage and Culture, 255.

89. Streusand, Islamic Gunpowder Empires, 147.

90. Matthee, "The Ottoman-Safavid War of 986-998/1578-90," 7.

91. Imber, The Ottoman Empire, 1300-1650, 45.

92. Matthee, “The Ottoman-Safavid War of 986-998/1578-90," 15. 
93. Hourani, A History of the Arab Peoples, 216.

94. Wheatcroft, "Islam's Final Push," 247.

95. Matthee, "The Ottoman-Safavid War of 986-998/1578-90," 1.

96. Matthee, "The Ottoman-Safavid War of 986-998/1578-90," 12-13.

97. Imber, The Ottoman Empire, 1300-1650, 46-47.

98. Newman, Safavid Iran, 21.

99. Colin P. Mitchell, The Practice of Politics in Safavid Iran: Power, Religion, and Rhetoric (London: I. B. Tauris, 2009), 68.

100. Mitchell, The Practice of Politics in Safavid Iran, 145.

101. Dale, The Muslim Empires of the Ottomans, Safavids, and Mughals, 91.

102. Streusand, Islamic Gunpowder Empires, 151.

103. Streusand, Islamic Gunpowder Empires, 152.

104. Newman, Safavid Iran, 3.

105. Newman, Safavid Iran, 50.

106. Newman, Safavid Iran, 74.

107. Dale, The Muslim Empires of the Ottomans, Safavids, and Mughals, 178.

108. Imber, The Ottoman Empire, 1300-1650, 78-79.

109. Hanson, Carnage and Culture, 262.

110. Dale, The Muslim Empires of the Ottomans, Safavids, and Mughals, 93.

111. Polk, Understanding Iraq, 60.

112. Bernard Lewis, From Babel to Dragomans: Interpreting the Middle East (Oxford: Oxford University Press, 2004), 50.

113. Lewis, From Babel to Dragomans, 50.

114. Lewis, From Babel to Dragomans, 43.

115. Streusand, Islamic Gunpowder Empires, 154.

116. Newman, Safavid Iran, 76-78.

117. Curry, review of Islamic Gunpowder Empires, 353.

118. Shaw, Empire of the Gazis, 170.

119. Shaw, Empire of the Gazis, 170.

120. Dale, The Muslim Empires of the Ottomans, Safavids, and Mughals, 87-88.

121. Streusand, Islamic Gunpowder Empires, 146.

122. Graham Allison, Destined for War: Can America and China Escape Thucydides's Trap? (Boston: Houghton Mifflin Harcourt, 2017), introduction, Kindle. 


\title{
The British Superpower, Irregular Warfare, and Military Honor
}

\author{
T. J. Linzy, PhD
}

\begin{abstract}
Even the simplest of military operations can be made complex due to a superpower's ubiquitous participation in geopolitical, legal, diplomatic, and commercial environments. With its layered and competing priorities, it can be difficult for the superpower's armed forces to complete missions successfully with individual integrity and honor. Furthermore, irregular warfare demands special consideration due to its unique circumstances and occasionally unusual allies. This article will examine a historical episode from the War of 1812, seen from the British superpower and a small Royal Marine detachment's perspective that illuminates some of these timeless challenges.
\end{abstract}

Keywords: Creeks, Seminoles, War of 1812, Battle of New Orleans, Major Edward Nicolls, Major General Andrew Jackson, Royal Marines

The chief utility of history for the analysis of present and future lies in its ability, not to point out lessons, but to isolate things that need thinking about. ... History provides insights and questions, not answers.

-Geoffrey Till ${ }^{1}$

he purpose of this article is to illuminate how irregular warriors' values sometimes conflict with those of the superpower when dealing with indigenous forces within a larger conflict, particularly when discussing

T. J. Linzy is an independent scholar who received his MA and PhD from the War Studies Department of King's College London. Linzy's work focuses on the Sixty Years' War for control of the American Midwest, 1755-1815. 
ideals such as honor. Most superpower special forces would defend their military honor to the death in tactical situations, but sometimes the operational and strategic requirements of the superpower's overarching objectives come into conflict with the warriors' personal honor. Preparation for such conflict of values is the goal of this historical examination. There is a tendency in our hightech warfare age to think that much of what happens in modern war is unique to our time. However, the circumstances and dilemmas from this little-known episode from the War of 1812 will be hauntingly familiar to Western special forces units in the twenty-first century.

It is difficult to read about the War of 1812 without encountering the word "honor." The United Kingdom's (UK) maritime supremacy, the UK's encouragement of North American indigenous tribes to resist the United States' westward expansion, the United States' inability to peacefully resist naval impressments, and the American intention of maintaining neutral trading rights with European nations made honor one of the key motives for the United States to declare war. ${ }^{2}$ Although the concept of military honor was undergoing significant changes in this era, it continued to be a critical part of military culture. The long Napoleonic Wars had forged a new generation of military men whose experience had revived military honor once the ideological extremes of the early revolutionary times proved incapable of building effective forces. ${ }^{3}$ However, ideology was not completely discarded. Warriors and armed forces embraced more than just glory and country. To the traditional virtues that comprised military honor, such as courage, prowess, and loyalty, were added the broader concepts of individual conscience, such as merit, liberty, and justice. With these additional virtues came the increased possibility that individual combatants' views of military honor could come into conflict with the objectives of their country. The UK's Gulf of Mexico amphibious campaign in the War of 1812 was susceptible to this possibility due to the changing cultural norms and distinctive personalities involved. A Royal Marine officer of the British superpower had to examine his personal loyalties, integrity, and honor when faced with his own country's unwillingness to support indigenous allies when that support would endanger larger priorities for the British superpower.

\section{Background}

After the victory over France and Spain in the Seven Years' War (a.k.a. the French and Indian War in North America), the UK had secured its first global empire. The loss of most of its North American colonies in the American Revolutionary War shortly thereafter diminished its holdings, but the UK maintained alliances with indigenous tribes within the geographical boundaries of the United States through Canada and the Caribbean. With its remaining influence in North America and continued dominance of the seas, especially the Atlantic Ocean, 
British near-hegemony of the Atlantic world seemed an unlikely setting for a war started by the newly established United States. However, the UK was not free from constraints. The Napoleonic Wars were entering their third decade when the United States declared war on Britain in 1812. The UK's conventional land power was sparse in North America, so it decided to rely on indigenous auxiliaries as the primary means of combating the American invasion of Canada and the defense of the Gulf of Mexico.

This article will specifically focus on the UK's Gulf of Mexico campaign that took place in the last six months of the War of 1812. However, context is needed to understand the frames of mind that the Creeks, Seminoles, and the U.S. settlers (who would provide the bulk of Andrew Jackson's force) before the UK entered this part of the War of 1812.

By 1811, the Shawnee war chief, Tecumseh, had united many of the tribes of the upper Midwest in their resistance to the U.S. encroachment on their lands. A native religious revival of sorts had taken hold in many parts of the tribes of the Midwest, both north and south. Tecumseh, along with his brother, Tenskwatawa (the Prophet), led the movement for intertribal unity. In the second half of 1811, Tecumseh traveled to the southern tribes in an attempt enlist them in his native coalition. Tecumseh met fierce resistance from the Choctaw, the Chickasaw, and half of the Creek nations. However, the other half of the Creek were receptive to his message of resistance to U.S. encroachment. ${ }^{4}$ This precipitated a factional split within the Creek nation. The Red Stick Creeks sided with Tecumseh and the White Stick Creeks sided with the United States and its agent, Benjamin Hawkins. Tecumseh traveled back to his homeland in late 1811 to oversee the resistance to the United States and the alliance with the British there. The Creek split worsened throughout 1812 with Red Stick attacks and thefts against the White Sticks and the U.S. settlers that were living in the areas of modern-day southern Alabama and the panhandle of Florida. By the first half of 1813, the attacks had grown routine and the two factions were on the brink of civil war. ${ }^{5}$

In the meantime, the Red Sticks received more of their supplies from the Spanish in Florida and British traders from the Bahamas that were allowed by the Spanish to operate in Florida. This created tension with the U.S. settlers in the area who were already suspicious of the British stirring up native unrest. On 27 July 1813, a mixed U.S. militia and White Stick force ambushed a Red Stick supply pack train coming from Spanish Pensacola at the Battle of Burnt Corn. The Red Sticks were caught by surprise and lost some of their supplies, but managed to beat back the attack and forced the United States and the White Stick party to retreat. In direct response to the Burnt Corn attack, the Red Sticks planned an attack on the Tensaw settlements north of Mobile. Word of their plans preceded them and many of the settlers and White Sticks congre- 
gated at a fortified settlement named Fort Mims. On 30 August 1813, the Red Sticks struck. The fort was overtaken and a general massacre of the settlers and White Sticks took place. The news of the Fort Mims massacre tore through the south like wildfire. An area that had largely been free from repercussions of the War of 1812 was to be engulfed by it. $^{6}$

In the north, the UK relied on indigenous tribes heavily and built a combat force in the northern theater in partnership with a coalition of tribes led by Tecumseh and Tenskwatawa. The relationships with the northern tribes had been irregularly maintained by the British in the decades following the American Revolutionary War. These relationships (and similar ones in the south) were contributing factors to the U.S. mistrust of UK intentions in the new country. At the onset of the War of 1812, the British tried to integrate the indigenous allies into their standard battle groups and tactics. The United States used allied tribes as well, but in limited and traditionally North American manners, such as scouting, guiding, and raiding.

The UK's heavy use of tribes in the north was a case of necessity, because the British viewed the war with Napoleonic France as one for survival and could not spare a large body of troops to defend Canada. However, this decision would cost them in the court of public opinion. After a lopsided UK victory at the battle on the River Raisin near modern-day Detroit, Michigan, in January 1813, British officers left the battlefield and entrusted their tribal allies with the U.S. prisoners, mainly Kentucky militiamen. The indigenous allies killed some of the U.S. captives, including the wounded that had been left in their care by British Colonel Henry A. Procter. The UK condemned the massacre, but the United States felt the British had turned a blind eye to the obvious dangers of such a situation. There were not a large number of such atrocities, but the UK establishment worried that they would be victorious in the war of ideology in civilized Europe, only to be considered barbarians by their American cousins. ${ }^{7}$

By late 1813, a militia force from Tennessee led by Andrew Jackson was on its way south to link up with Alabama militias and White Stick Creeks to confront the Red Stick Creeks. U.S.-friendly Cherokee and Choctaw also were recruited in the war effort. After a series of actions in late 1813 and early 1814 along the modern-day border between Alabama and Georgia, the Creek War culminated in the Battle of Horseshoe Bend on 27 March 1814, where Jackson and his combined forces assaulted a fortified Red Stick position on the horseshoe bend of the Tallapoosa River. The battle was a lopsided victory for the United States with more than a thousand Red Sticks killed or wounded. In August 1814, Jackson would impose the Treaty of Fort Jackson on the Creeks, Red Stick, and White Stick alike and took nearly 23 million acres from the Creek nation for the United States. ${ }^{8}$

Because of such events as Fort Mims and the River Raisin, the United 
States took the UK's use of indigenous tribes seriously and the British knew that their use would be inflammatory and possibly embarrassing to their honor. Many of the U.S. militia in Jackson's coalition were from Kentucky, Tennessee, and the Mississippi Territory where these atrocities had happened and were looking for revenge for their losses. The stage was set for the peculiarly modern circumstances of indigenous irregular forces led by a superpower's small military detachment and all of the complexities inherent in such endeavors.

\section{Summary of Military Honor in the Era}

There are two common classifications of honor: external and internal. ${ }^{9}$ External honor is "similar to words such as reputation, prestige, face, and name." Internal honor is "closer to conscience or integrity." They coexist and feed each other. Therefore, it is hard to separate them in a military environment. If a society values prowess, courage, loyalty, and truthfulness as attributes of successful warriors, then these attributes become attractive to those who seek external honor. Aspiring warriors, and the communities they live in, internalize these attributes as honorable. Eventually, they turn them into character traits to be valued in and of themselves. Paradoxically, these internalized traits can take precedence over success and external honor when warriors have been deeply inculcated by a code of honor. Similarly, the quest for external honor has led more than a few warriors to conduct themselves in ways that few would recognize as internally honorable, such as burning an entire village in retribution for a deadly sniper attack on one's unit that emanated from that village. ${ }^{10}$

Honor traditionally needs an "honor group" of like-minded individuals to behold the individual's honorable virtues and understand that they are striving to keep them sacred. Virtues within the honor group are not necessarily moral or ethical, but they are consistent with the values of the honor group. ${ }^{11}$ Honor within modern-day gangs, terrorist groups, and the mafia underline the neutrality of the term. Honor groups often form around existing organizations, such as families, corporate entities, churches, and, of course, military units. However, honor groups can form around ideological concepts as well, such as liberty and worker solidarity (i.e., Marxist and class-driven ideology). Military honor groups have been one of the greatest strengths and greatest weaknesses of military units. Individuals have been known to go to superhuman lengths to uphold military honor within their group, but they have also committed great depravities when trying to live up to the group's expectations. The military honor group can have several hierarchies as well. A Royal Marine officer could have belonged to honor groups of the UK, the British armed forces, the Royal Navy, the Royal Marines, fellow officers, and a ship, among others. These simultaneous, sometimes complementary or competing groups, could form quite complex permutations. If an officer had been told of an indiscretion of a fellow 
officer in confidence, did they owe their honor to the fellow officer or the good of the officer corps in general? The answer was almost always personal. No matter how hard a nation or an armed service might try to imbue a sense of duty to their own organization above all others, the individual was left to sort out the consequences of their own actions.

Prior to the French Revolution in Europe, these concepts, in the military sense at least, were largely aristocratic notions. The military officers of the pre-Napoleonic era were generally men of standing in monarchical societies. This relatively small group shared an idea of honor that cut across national boundaries and appealed to an elite that was not skilled in the military science of large armies, but in personal prowess and courage on horseback. The individual soldiers were expected to be of low moral standing. The best that could be expected was that appeals to the higher authorities of God and king would keep the rabble from committing too many atrocities. However, after the French Revolution and the advent of the levee en masse-mass national conscription of all able-bodied young men in France that brought all classes of society into contact under the banner of liberty, equality, and fraternity-ideological issues increasingly substituted for mere dedication to a monarch. The powers of Europe lined up on either side of the Napoleonic Wars to promote their own version of liberty and duty. These concepts of universal liberty and justice were added to courage, duty, and prowess to form a new kind of internal honor that was justified in and of itself. No longer were the nobles the only ones required to display honor. ${ }^{12}$ As N. A. M. Rodger stated when writing about the rising status of British naval officers, "[t]his implied a new underlying ideal, one in which duty was beginning to infiltrate the concept of honor." ${ }^{13}$ The Royal Navy officer needed to be a gentleman but also a professional seaman that required years of training resembling an apprenticeship. What developed was a service elite that had the working values of the rising middle class. ${ }^{14}$

Not all issues of honor were defined merely by the developments of Revolutionary France. Honor permeated much of intellectual life, culture, and philosophy in the half century prior to the War of 1812. The end of the Enlightenment and the beginning of the Romantic movement occurred in Europe in this era. Philosophers such as Immanuel Kant and Jean-Jacques Rousseau were providing the intellectual and philosophical basis for individuals to act with honor with and without external impetus. ${ }^{15}$ Writers such as Sir Walter Scott and Johann Wolfgang von Goethe were making clear that the individual could enjoy the higher pleasures of honor through their own merit. These developments coincided with the abolition movement that was famously championed by William Wilberforce. ${ }^{16}$ In the United Kingdom, poets such as Samuel Taylor Coleridge and William Wordsworth were teasing out the elements of honor in verse that sought a "natural" and personal honor. ${ }^{17}$ Coleridge served 
as an aide to British Admiral Alexander John Ball, one of Vice Admiral Horatio Nelson's "band of brothers." Many of Britain's naval and Marine officers were very close to other developments in British societal and cultural life, often due to their wealth from naval prize money. Furthermore, one need not prove that Royal Navy and Royal Marine officers were reading Rousseau or Kant to suggest that they held a romantic notion of military honor. Scott was a best-selling novelist and Wordsworth and Coleridge's poems were widely read. Linda Colley claims these romantic notions led to an "ostentatious cult of heroism" where the blue bloods now sought the association of red-blooded heroes. In other words, the upper classes wanted to mix with the heroes who were expanding the British Empire, but who did not possess aristocratic bloodlines. ${ }^{18}$ By the time of the War of 1812, all of these concepts were in wide circulation in Europe.

The virtues of honor were not the only changing norms of the time. Racial tolerance and respect for native cultures were ideas gaining ground in the Royal Navy. Sailors and Marines were more likely to have served in places where indigenous peoples were encountered than the average British soldier who was fighting in Europe. There was scarcely a place on earth that sailors or Marines had not seen indigenous people living close to nature. Additionally, the men of the British fleet had seen the horrors of the slave trade firsthand when encountering slave ships in the Atlantic. That does not mean that all in the Royal Navy saw this issue in the same light. Admiral John Jervis, Earl of St. Vincent, was on record ridiculing the Slave Abolition Bill in Parliament and Admiral Alexander I. Cochrane was also a slave owner in the West Indies. ${ }^{19}$ However, on the whole, the issues were more current and pressing in the Royal Navy than in the average segment of British society. These sensitivities were certainly present in the form of Royal Marine Major Edward Nicolls at Prospect Bluff, Florida, on the Apalachicola River in late 1814.

Although this article is about the British superpower, it is instructive to look at their Creek and Seminole allies' and the American's view of military honor as well. The Creek took honor in warfare very seriously as it formed the basis for male rank in their society. ${ }^{20}$ As with most natives of North America, taking the scalp of a defeated foe was a way to prove the virtues of military honor like bravery, stealth, and a disregard for one's own safety in combat. Contrary to popular history, however, scalping was not generally the highest goal of an indigenous warrior. It was normally the second-best outcome and only valued when a prisoner could not be taken alive. Prisoners were much more highly valued, so the warrior could show the home village that he had been successful. A prisoner also allowed the villagers, including women and children, to partake in the ritualized torture that displayed a village's outpouring of violent grief. This was obviously at odds with newer European ideas of prisoner treatment, but the Native Americans and Europeans had become adept at keeping their traditions 
around each other without flaunting the issue when they wanted to do so. ${ }^{21}$ The issue of abolition was well known in the southern indigenous communities as well, largely through British traders such as Thomas Brown in the Revolutionary era and William Augustus Bowles in the Anglo-American interwar years. Free blacks intermarried with the Creek and the Seminole, but other blacks were also held as slaves as the onset of white farming practices took root in indigenous culture. ${ }^{22}$ Sobriety was also valued in times of war and alcohol was prohibited at highly formalized war councils. The purification ceremony performed at the beginning of such councils involved drinking cassina, a plant high in caffeine and black in color. This often induced vomiting, which was considered cleansing for the body. The concept was that warriors would be clearheaded in combat and when discussing war. Finally, at least one traveler through Creek country witnessed a national leader encourage their warriors to exhibit courage and "to sacrifice everything for the love of nation and liberty." ${ }^{23}$ Other than refraining from scalping, at least in the presence of the British, it seems the British had a receptive audience in the indigenous tribes when attempting to inculcate the virtues they carried as military honor.

In the sense of ideology, personal merit, and the idea of the individual holding honor outside of social status, Americans were stereotypically anti-elite in their nature. However, some aspects of external honor remained, specifically acts such as dueling. Antidueling tracts were almost de rigueur for the Romantics like Walter Scott. In the United States, however, the practice still was widely practiced. Alexander Hamilton was famously killed by sitting Vice President Aaron Burr in a duel in 1804. Andrew Jackson took command at the onset of the Creek War with a grievous wound due to dueling in 1813 and was said to have participated in many during his lifetime. ${ }^{24}$ However, there was not a clear-cut distinction between the United States and Britain regarding dueling as dueling was not unknown at this time in Britain. George Canning and Robert Stewart, Lord Castlereagh, dueled in 1809 and Arthur Wellesley, the Duke of Wellington, dueled with George Finch-Hatton, the Earl of Winchislea, in 1829. However, the exceptions were so well publicized and condemned that they proved the rule. It was more prevalent in the United States, especially in the south, and most famously in the opening of the American West throughout the nineteenth century. ${ }^{25}$ Of course, Romanticism was known in the United States, but America, and the southern part especially, were still pre-Romantic in the literary sense. Romantic authors Washington Irving, James Fennimore Cooper, and Nathaniel Hawthorne had yet to write their masterpieces. As for honor in the tactics of warfare, John Grenier has argued forcefully that Americans of the time, especially on the frontier with the indigenous tribes, practiced a form of warfare that was far closer to the Native American way of war than the European one. ${ }^{26}$ For the American combatants in the War of 1812, which were 
overwhelmingly militiamen, their honor group often resided in the frontier communities rather than in professional military units. ${ }^{27}$ Protecting their communities from the indigenous tribes allowed for virtually any tactic available if the situation warranted it.

Finally, military honor did not, and still does not, equate to the law of war. There are no positive martial virtues in the law of war, only negative ones. The law of war does not dictate courage, prowess, or prohibit cowardice-it only dictates constraints on the way war is conducted. However, many of the constraints on war, in the Western world at least, were developed from the chivalric code and Christian ethics that hold many of the traditional virtues of military honor as well. Therefore, in military circles, the law of war was quite often the equivalent of what was done or not done. The law of war as a formal concept was the attempt to internationalize various codes in practice to limit the worst and most egregious aspects of war among cultures that valued the same things. ${ }^{28}$ As with so many issues, most notably property rights, Western values did not, and often did not try to, reconcile themselves with the culture of the Native Americans. Hence, the indigenous tribes, European Americans, and British shared most of the positive martial values, such as courage in the face of the enemy, decisive leadership, and dedication to comrades, but the constraints often were incomprehensible to each other. Their worlds were just too different. Thus, the warring parties of the War of 1812 consisted of a British culture of legalistic constraints, an indigenous culture of elemental constraints (defense of hunting areas and crops as well as their way of life), and a European American culture of frontier constraints. Of course, in developing the international law of war, maritime law often led the way. Therefore, it is not difficult to assert that Royal Navy officers who worked internationally would have been far more sensitive to the constraints of the law of war, and those honor groups, than either an indigenous warrior or an American militiaman on the frontier.

\section{Gulf of Mexico Operations in the War of 1812}

With the war against Napoleon still raging in Europe, Britain found itself failing to decisively defeat the United States in the War of 1812. The difficulty for Britain was that it had very few land resources left to materially affect the situation. The Royal Navy did have some resources, but it did not have enough to wage coordinated campaigns on multiple fronts. The actions around Chesapeake Bay were holding down most of the Royal Marine forces. The British Army, having secured Canada from invasion, was still struggling to strike back decisively against the United States along the Lake Champlain and Niagara River corridors. To change the situation substantially, the British needed to divert a large segment of the U.S. fighting power away from the north. A plan to attack the Gulf of Mexico coast with Native Americans, namely Creeks and Seminoles 
as auxiliaries, had been contemplated by the senior leadership in London, the Bahamas, and the Royal Navy since the beginning of the war. ${ }^{29}$ In 1814 , the Royal Navy Vice Admiral Alexander Cochrane renewed the idea with the governor of the Bahamas, Charles Cameron, and pitched it to London again. The British secretary of state for war and colonies, Henry Bathurst, the Third Earl of Bathurst, decided to assault the Gulf of Mexico coast to force the United States to move troops and supplies away from the Great Lakes, Northeast, and Chesapeake Bay theaters. The British felt the Gulf Coast was strategically important to the United States, because the ports of Mobile, Alabama, and New Orleans, Louisiana, provided a vital outlet for the agricultural exports from the trans-Appalachian states and territories. ${ }^{30}$

Although the British had finally committed to using the Creeks in their effort to assault the Gulf Coast, they were too late to help the Creeks fight for their own homeland. When Cochrane started landing supplies and weapons in April 1814, Major General Andrew Jackson, commander of the U.S. 7th Military District that encompassed the central Gulf Coast, had already devastated the warring faction of the Creeks, the Red Sticks, in battle at Horseshoe Bend in present-day Alabama. ${ }^{31}$ From the mouth of the Apalachicola River in Spanish West Florida in the summer of 1814 , the British recruited the remnants of the Red Stick Creeks, along with the local Seminoles, who feared similar treatment from Jackson. Cochrane landed a small Royal Marine detachment and later Royal Marine Major Edward Nicolls to train the indigenous tribes and prepare for operations against the southern coast. ${ }^{32}$ To induce them to join, the British promised the Creeks that they would be remembered in any peace treaty. If they served with Nicolls, the British would help them regain the land they lost during their war against the Americans. ${ }^{33}$ Simultaneously, with British operations in the Iberian Peninsula against Napoleon coming to a close, the British government freed veteran troops to participate in the Gulf Coast assault. These forces were led by one of Britain's best young generals, Sir Edward M. Pakenham. This meant that the Native Americans would not be the main assault force but were supporting units that would hold down American forces in West Florida, Georgia, and present-day Alabama while the main body attempted to capture New Orleans. ${ }^{34}$

Nicolls and his Marines landed a significant number of weapons, uniforms, and accoutrements and drilled the indigenous warriors in British military skills in the countryside around Prospect Bluff on the Apalachicola River. ${ }^{35}$ By the late summer of 1814, this irregular force led by Nicolls was ready to begin operations. As the first part of the British operational plan, Nicolls's force was to operate near Pensacola and Mobile to draw American forces to the area in the belief that Mobile was to be the main point of British attack. If the operations were successful, Nicolls was to turn west and scout the routes to New Orleans. 
The presence of the British and Native American force certainly had Jackson's attention, and he was busy moving units to the area and constantly reconnoitering the Gulf Coast for suspected British landings. On 12 September 1814, Nicolls and Captain William H. Percy of the Royal Navy conducted a joint assault on Fort Bowyer, which protected the entrance to Mobile Bay, in preparation for attacking Mobile. Nicolls's indigenous and Royal Marine force attacked the fort from the land while Percy assaulted from the shallow waters around Fort Bowyer. However, the defenders of Fort Bowyer were not the raw militia that the British had come to expect from the Americans, but they were U.S. infantry regulars who fought admirably and defended the fort. The Americans won by blowing up a Royal Navy ship and holding Nicolls's Native Americans at bay with grapeshot. ${ }^{36}$ The attack was a disaster for Nicolls's hopes of using the indigenous tribes in a proactive campaign to support the main British landings, but he had accomplished the campaign's diversionary purpose as Jackson became convinced that the British would attack Mobile in force. Nicolls retired to Pensacola to prepare for the next operation.

The British had met with the Spanish governor of West Florida, Mateo González Manrique, of Pensacola, who was very concerned about an American attack, because Andrew Jackson had made clear that he thought the Spanish were aiding and abetting the British and Native Americans. The British eventually convinced Governor Manrique that only Nicolls and his indigenous force could protect Pensacola from American attack. However, Manrique's prevarication on whether to allow Nicolls to fully prepare Pensacola for a defense against Jackson meant the plan was doomed from the beginning. On 7 November 1814, Jackson invaded Pensacola and Nicolls had to evacuate by ship for Prospect Bluff again, blowing up the military stores before he left. ${ }^{37}$

At this point, it became clear that Nicolls's Native American force would not play a significant role in supporting the British regulars in the main assault on the Gulf Coast. However, they had proven their worth in creating a diversion. Cochrane had determined the main British landings would be at New Orleans. Once Jackson got word of this, he moved to New Orleans to conduct the defense personally. However, Jackson had to send a force under Major Uriah Blue to search out Nicolls's force and keep it at bay and protect his flank. With Blue's force, the regulars at Fort Bowyer, and militia units from Georgia having to hold the area in defense from attack by Nicolls's Native Americans, the diversionary mission was a great success. Nicolls's Native Americans fought skirmishes, mainly against Major Blue's force, in the marshes and swamps of West Florida, but were never heavily engaged again in the war.

After the West Florida skirmishes with Blue's forces, Nicolls boarded a Royal Navy vessel prior to the battles around New Orleans in late 1814 and early 1815. Nicolls, being the senior Royal Marine present, asserted his right to lead 
the Marine force of 200 that helped Colonel William Thornton nearly turn Jackson's flank by taking the American position on the west side of the Mississippi River during the Battle at Chalmette Plantation outside New Orleans. ${ }^{38}$ However, Admiral Cochrane, not knowing that a peace had been agreed in Ghent, Belgium, on 24 December 1814, refused to let Nicolls take command as he was too valuable to the success of the indigenous force to lose. Conjecture could easily build a case that Nicolls's force could have made the difference on the west bank, but balance would demand that Jackson would have had Major Blue's force and more Georgia militia present as well. Cochrane assaulted Fort Bowyer again in February 1815 with British forces only, took it handily, and was preparing to assault Mobile when news of the Treaty of Ghent arrived on HMS Brazen (1808).

The Battle of New Orleans holds one last salient story that helps expose the different ways the United States and Britain saw honorable action and the use of Native Americans. The British superpower was accustomed to fighting the French superpower and engaging with other near-peer powers in Europe where most of their honor group resided. Therefore, European conventions were applied to their Creek and Seminole allies. The Americans, on the other hand, were in no sense a superpower at the time and had little time for European conventions in warfare when it did not suit them. Between the major engagements that constituted the Battle of New Orleans, the British complained to the U.S. commander, Major General Andrew Jackson, about the shooting and scalping of British sentries in the night by Choctaw "assassins." The response was a stereotypically Jacksonian "sentinels of the opposing armies would be running great risks to drink out of the same stream." Having experienced Creek warfare in the previous year, Jackson and his militias were in no mood for European conventions of gentlemanly sentry duty. ${ }^{39}$ Lieutenant George R. Gleig of the British Army tells this story and reminds his reader that French and British sentries in Spain would exist 20 yards apart and not fire at each other unless a major attack was about to begin. ${ }^{40}$ The United States, however, thought that the UK had already bloodied their hands at the River Raisin and Fort Mims by supporting the indigenous warriors along the frontier. This single example alone would not raise a question. However, the use of Native Americans in the broader campaign and the particular circumstances that they were recruited, trained, and led does.

Article 9 of the Treaty of Ghent stated that as a condition of peace, the Native Americans allied with the British were to be returned to their position of 1811. This seemingly included the Creeks who had lost nearly 23 million acres in the Treaty of Fort Jackson that was imposed in August 1814 by Andrew Jackson. Whether the British peace delegation at Ghent actually meant for the Creeks to be included in Article 9 is debatable, but the plain language of the article made it clear to Cochrane and Nicolls that the Creeks were included and the 
Treaty of Fort Jackson was null and void. ${ }^{41}$ However, Andrew Jackson did not see it that way. Jackson made sure that "his" treaty remained in force in direct contradiction to the orders he received from Washington, DC. ${ }^{42}$ The Creeks were enraged and perplexed. Not only did the Creeks believe that their British allies had taken care of them with the Treaty of Ghent, they viewed the Treaty of Fort Jackson as invalid on its face as it was only signed by the portion of the Creeks friendly to the United States anyway. ${ }^{43}$ Unfortunately for the Creeks, Andrew Jackson had made up his mind, and as long as he controlled the area, the Creeks would not regain their losses.

Although Cochrane and Bathurst felt responsible as well, this created a very personal problem for Major Edward Nicolls. Nicolls had given his wordreinforced by his ideals of honor-to his band of indigenous irregulars that they would be taken care of if they supported the British forces in the war. In the spring of 1815, Nicolls decided to remain long after the other British forces left the area to ensure the Creeks were going to be allowed back onto their lands by the Americans. At first, Nicolls wrote letters to Benjamin Hawkins, the agent for the Creeks, detailing the American responsibilities under the Treaty of Ghent. ${ }^{44}$ When these requests went unanswered, Nicolls increased the rhetoric and made threats of arming the indigenous tribes and signing a new treaty with them to enforce their rights. This did not go over well with the Americans who were, both locally and in Washington, DC, coming around to the idea that the Treaty of Fort Jackson would stand in spite of Article 9 of the Treaty of Ghent. ${ }^{45}$

The Seminoles, whom the British had also promised to help, were in an awkward predicament, because technically neither the Treaty of Ghent nor the Treaty of Fort Jackson applied to them, as they had never been officially at war with the United States. However, Nicolls's continued presence at Prospect Bluff was surely keeping them in Jackson's sights. In this case, Nicolls's very attempt to do the right thing by the refugee Creeks in Florida was endangering the native Floridian Seminoles. A vicious circle was developing. The Americans felt that Britain was not abiding by the Treaty of Ghent because Nicolls had remained and was inciting the Native Americans with talk of reclaiming their land. Nicolls was staying to ensure that the Native Americans were treated fairly by the Treaty of Ghent. Eventually, Nicolls understood that things were not going to get better for the Native Americans with him at Prospect Bluff. In the summer of 1815, Nicolls left Florida for London, taking the Red Stick chief (a.k.a. Francis the Prophet, Josiah Francis, and Hillis Hadjo) and his son with him to help the Creek make their case that their rights were being violated by the Americans and the British had a responsibility to intervene. ${ }^{46}$ In leaving, Nicolls handed over the fort at Prospect Bluff and all of its weapons and ammu- 
nition to remaining members of his unit that were mainly runaway black slaves that had also joined the British cause in the war. ${ }^{47}$ The fort became known as the "negro fort" to the Americans and would soon become the symbol of the British involvement in the area.

Unfortunately for Nicolls and the Native Americans, the British government had started to see the futility of disputing the terms of the Treaty of Fort Jackson. Cochrane intervened on Nicolls's behalf but to no avail. Nicolls hosted Creek and Seminole leaders in his English home for a year as he lodged pleas with the British government and the prince regent. The Earl of Bathurst was sympathetic as well. However, with a mountain of debt to service after two decades of war with France, an exhausted Britain would not entertain going to war with the United States again over the Creek land denial. The British gave the Americans assurances that the treaty that Nicolls had agreed to with the indigenous tribes in the spring of 1815 would not be signed by the UK government. The Native Americans were eventually given presents and sent home in the summer of $1816 .{ }^{48}$ Nicolls had found out the hard way that a Royal Marines' honor was not enough when principle and geopolitical pragmatism collide.

Remarkably, the Creeks and the Seminoles continued to look to London for support even after the British had abandoned them to suffer the terms of the Treaty of Fort Jackson. The Spanish were too weak to protect them and too economically feeble to trade with them. Nicolls was also still active in the area through his extended contacts in the Bahamas. One of his Royal Marine subordinates during the war, George Woodbine, remained in the Bahamas and was very active in promoting the idea that Florida would not be Spanish much longer and could well revert to being a British possession. Woodbine was promoting trade through one of his associates, Robert Armbrister, in the Prospect Bluff area. Nicolls, Woodbine, and Armbrister had their eyes not only on the trade with the Native Americans but also possibly on the opportunity to do some land speculation as well. Another British agent named Alexander Arbuthnot, a Bahamian merchant down on his luck, also showed up in Apalachicola Bay to trade with the Native Americans and became involved with Nicolls, Woodbine, and Armbrister in person and by correspondence. ${ }^{49}$ For their part, the Native Americans were looking for the material support needed to defend their lands and harass the Americans who were busy surveying the land cessions gained in the Treaty of Fort Jackson. The actions of Nicolls and his colleagues cannot be wholly attributed to their desire to restore and maintain their honor among the indigenous tribes, but it was a significant cause for their actions.

All of these actions (protesting the Treaty of Fort Jackson, demanding return of Creek land, promoting Creek rights to the UK government, and supply- 
ing the negro fort), except for Arbuthnot's, could be traced back to the unit that recruited the Native Americans and runaway black slaves. This fact, along with the inherent American paranoia about indigenous activities and the source of their weapons and ammunition, kept the situation simmering throughout 1815 and 1816. The Americans destroyed the negro fort in July 1816 as its presence was attracting runaway slaves from all over the south. However, the American forts built near the Florida border and the operations conducted to destroy the fort inflamed the Native Americans again. Attacks on American settlers and military patrols in the area increased, as did overall tensions. Armbrister and Arbuthnot became known to the American authorities. Arbuthnot made the mistake of mimicking Nicolls's previous demands that the Americans should live up to their treaty obligations. Arbuthnot and Armbrister's connections to Nicolls and Woodbine gave Jackson all the evidence he needed to be sure that the British government was still active in inciting the indigenous tribes against the United States. ${ }^{50}$

By the second half of 1817 , the situation had deteriorated and Jackson ordered the invasion of Spanish West Florida again. This time, the goal was to put an end to the Native American attacks and the British involvement in area. This campaign would become known as the First Seminole War. In a series of operations around the indigenous towns, the Americans engaged Native American forces, summarily executed their leaders, and burned crops and towns. In two different operations, Armbrister and Arbuthnot were captured. Jackson had them both brought to trial and executed. In their operations, Jackson's forces had captured Spanish St. Marks and Pensacola. The Spanish were incensed over the invasion of their territory and capture of their towns, and the British were incensed over the execution of two British citizens. Nicolls was not physically involved but felt the pain as his old Native American friend Francis had been executed as well. The U.S. government ordered Jackson to withdraw his forces from Spanish territory. Jackson did not like it, but he had made his point, and Spain would cede Florida to the Americans within three years. ${ }^{51}$

The outcome fit the Jackson narrative of British agents stirring up trouble, but the reality of the situation was more complex. Nicolls and Woodbine and their associates were not innocent, but at least some of their actions could be tied back to a sense of honor to the indigenous tribes who had been their comrades in arms in the War of 1812. However, the fact remains that not only did Nicolls not help the Native Americans after the war by his actions, there is a real case to be made that he worsened their situation. A good argument can be made that an absence of Nicolls, Woodbine, Armbrister, and Arbuthnot in Florida from 1815 onward would not have stopped the land-hungry Jackson and his colleagues, but their presence certainly made it easier to make the First Seminole War seem necessary in American eyes. ${ }^{52}$ 


\section{Conclusion}

A few specifics of this campaign present themselves that irregular warriors of a superpower's armed forces must consider when operating with allies that do not share all or even most of the superpower's objectives and cultural norms.

First, Major Nicolls's promises to his indigenous allies were subordinated to the overall geopolitical requirements of the British government. This was a difficult situation but probably the right decision for a war-weary Britain. If the irregular warrior can consider these issues beforehand, they might be able to avoid making unnecessary promises that might need to be broken when a superpower's overarching objectives overcome local circumstances.

Second, Major Nicolls made the obvious connection between the Seminoles and Creeks, but the Treaty of Fort Jackson was particular to the Creeks. When dealing with a specific group due to an operational need, their local partners might get involved, although they are not part of the superpower's mission. Thinking in advance about ways to separate groups that are linked from their perspective, but not from the superpower's perspective, might prevent mission extension for a superpower who is looking to exit a situation as soon as its objectives have been met.

Third, Major Nicolls held very strong ethical views and one would find it hard to question his honor in dealing with the Creeks. Personal honor is encouraged by most modern militaries, but personal honor will rarely be a reason for a modern military to give up its requirement to complete a war to a politically acceptable standard and time frame, especially when it is at odds with their superpower's goals. The irregular warrior who knows their limits on personal honor may have an advantage to one who is constantly trying to find their bearings in a quickly changing environment. Nicolls's views of slavery and the plight of the indigenous tribes were commendable but out of touch with the southern U.S. population. Personal views that come into conflict with local cultural norms may impede the irregular warrior's clear view of acceptable outcomes when exiting war. The irregular warrior who considers their range of views and how they are likely to fit into an assigned culture will be less likely to confuse personal views with mission critical issues. Engagement with irregular forces with diverse (and often competing) objectives adds many diplomatic permutations and competing interests that create complications to the cessation of hostilities. This complexity can lead to incomplete objectives, lost credibility, and continuation of hostilities in other forms.

These are just a few of the difficult situations that irregular warriors of a superpower's military might consider. However, one must heed Till's advice. The study of history cannot provide detailed instructions on how to avoid all pitfalls, but it can provide insights and questions for deliberation before operations begin. 


\section{Notes}

1. Geoffrey Till, Maritime Strategy and the Nuclear Age (London: Macmillan, 1982), 224-25.

2. Reginald Horsman, The Causes of the War of 1812 (Philadelphia: University of Pennsylvania Press, 1962), 228-29.

3. Gunther Rothenberg, "The Age of Napoleon," in The Laws of War: Constraints on Warfare in the Western World, ed. Michael Howard, George J. Andreopoulos, and Mark R. Shulman (New Haven, CT: Yale University Press, 1994), 86-97.

4. Sean Michael O'Brien, In Bitterness and in Tears: Andrew Jackson's Destruction of the Creek and Seminoles (Guildford, CT: Lyons Press, 2005), 18-26.

5. Gregory Evans Dowd, A Spirited Resistance: The North American Indian Struggle for Unity, 1745-1815 (Baltimore, MD: Johns Hopkins University Press, 1993), 156-57.

6. John Buchanan, Jackson's Way: Andrew Jackson and the People of the Western Waters (Hoboken, NJ: John Wiley \& Sons, 2001), 216-25.

7. Sandy Antal, $A$ Wampum Denied: Procter's War of 1812 (Ottawa, ON: Carleton University Press, 1997), 161-83.

8. Robert V. Remini, Andrew Jackson and His Indian Wars (London: Penguin Books, 2001), 62-79.

9. T. J. Linzy, "Did Military Honour Hinder the Royal Navy's Effective Use of North American Indians in the Gulf of Mexico Campaign in the War of 1812?" (masters' thesis, King's College London, 2009), 9-18, https://doi.org/10.13140/2.1.3147.9049.

10. Paul Robinson, Military Honour and the Conduct of War: From Ancient Greece to Iraq (London: Routledge, 2006), 2-3.

11. James Bowman, Honor: A History (New York: Encounter Books, 2007), 4-5.

12. Rothenberg, "The Age of Napoleon," 81.

13. N. A. M. Rodger, The Command of the Ocean: A Naval History of Britain, 1649-1815 (London: Penguin Group, 2004), 513.

14. N. A. M. Rodger, "Honour and Duty at Sea, 1600-1815," Historical Research 75, no. 190 (November 2002): 425-47.

15. Alexander Welsh, What Is Honor?: A Question of Moral Imperatives (New Haven, CT: Yale University Press, 2008), 131-32, 139-40.

16. Bowman, Honor, 75-80.

17. Adam Nicolson, Men of Honour: Trafalgar and the Making of the English Hero (London: Harper Perennial, 2005), 115.

18. Linda Colley, Britons: Forging the Nation, 1707-1837 (New Haven, CT: Yale University Press, 2009), 177-78.

19. Edward Pelham Brenton, Life and Correspondence of John, Earl of St. Vincent, vol. 1 (London: Henry Colburn, 1838), 207-8; and C. J. Bartlet and Gene A. Smith, "A 'Species of Milito-Nautico-Guerilla-Plundering Warfare': Admiral Cochrane's Naval Campaign Against the United States, 1814-1815," in Britain and America Go to War: The Impact of War and Warfare in Anglo-America, 1754-1815, ed. Julie Flavell and Stephen Conway (Gainesville: University of Florida Press, 2004), 173-204.

20. Robbie Etheridge, Creek Country: The Creek Indians and Their World (Chapel Hill: University of North Carolina Press, 2003), 103-4.

21. Wayne E. Lee, "Peace Chiefs and Blood Revenge: Patterns of Restraint in Native American Warfare, 1500-1800," Journal of Military History 71, no. 3 (July 2007): 701-41, https://doi.org/10.1353/jmh.2007.0216.

22. J. Leitch Wright Jr., Creeks and Seminoles: The Destruction and Regeneration of the Muscogulge People (Lincoln: University of Nebraska Press, 1990), 251.

23. Etheridge, Creek Country, 105-6.

24. Robert V. Remini, Andrew Jackson, vol. 1, The Course of American Empire, 1767-1821 (Baltimore, MD: Johns Hopkins University Press, 1998), 181-85.

25. Frank Lawrence Owsley Jr., Struggle for the Gulf Borderlands: The Creek War and the Battle for New Orleans, 1812-1815 (Tuscaloosa: University of Alabama Press, 2000), 186. 
26. John Grenier, The First Way of War: American War Making on the Frontier (Cambridge: Cambridge University Press, 2008), 221-25.

27. Grenier, The First Way of War, 204-20.

28. Michael Howard, "Constraints on Warfare," in The Laws of War, 1-5.

29. Richard K. Murdoch, "A British Report on West Florida and Louisiana, November, 1812," Florida Historical Quarterly 43, no. 1 (July 1964): 42-51, 54-69.

30. Frank Lawrence Owsley Jr., "British and Indian Activities in Spanish West Florida during the War of 1812," Florida Historical Quarterly 46, no. 2 (October 1967): 111-23.

31. Owsley, Struggle for the Gulf Borderlands, 72-85.

32. Wilburt S. Brown, The Amphibious Campaign for West Florida and Louisiana, 18141815: A Critical Review of Strategy and Tactics at New Orleans (Tuscaloosa: University of Alabama Press, 1969), 27.

33. John Sugden, "The Southern Indians in the War of 1812: The Closing Phase," Florida Historical Quarterly 60, no. 3 (January 1982): 273-312.

34. Owsley, Struggle for the Gulf Borderlands, 134-35.

35. Mark F. Boyd, "Events at Prospect Bluff on the Apalachicola River, 1808-1818: An Introduction to Twelve Letters of Edmund Doyle, Trader," Florida Historical Quarterly 16, no. 2 (October 1937): 55-96.

36. Owsley, Struggle for the Gulf Borderlands, 101-12.

37. Ruth Anna Fisher, "The Surrender of Pensacola as Told by the British," American Historical Review 54, no. 2 (January 1949): 326-29, https://doi.org/10.1086/ahr/54.2.326.

38. Owsley, Struggle for the Gulf Borderlands, 153-64.

39. Brown, The Amphibious Campaign for West Florida and Louisiana, 1814-1815, 109, 118; and John Buchanan, Jackson's Way: Andrew Jackson and the People of the Western Waters (Hoboken, NJ: John Wiley \& Sons, 2001), 352.

40. George Gleig, The Campaigns of the British Army at Washington and New Orleans, in the Years 1814-1815 (London: John Murray, Albemarle Street, 1836), 313-14; and Richard Holmes, Redcoat: The British Soldier in the Age of Horse and Musket (London: HarperCollins, 2001), 374.

41. J. Leitch Wright Jr., "A Note on the First Seminole War as Seen by the Indians, Negroes, and Their British Advisers," Journal of Southern History 34, no. 4 (November 1968): 565-75.

42. Remini, Andrew Jackson and His Indian Wars, 94-97.

43. Wright, Creeks and Seminoles, 185-86.

44. "Indian agent," Merriam-Webster, accessed 9 November 2018. An Indian agent was an official representative of the U.S. federal government to American indigenous tribes, especially on reservations.

45. Remini, Andrew Jackson and His Indian Wars, 99-101.

46. Wright, "A Note on the First Seminole War as Seen by the Indians, Negroes, and Their British Advisers," 569-71; and Sugden, "The Southern Indians in the War of 1812," 307-8.

47. Nathaniel Millett, "Britain's 1814 Occupation of Pensacola and America's Response: An Episode of the War of 1812 in the Southeastern Borderlands," Florida Historical Quarterly 84, no. 2 (Fall 2005): 229-55. Slave recruitment is out of scope in this article, but Nathaniel Millett gives a detailed account of Nicolls's activities among the slaves.

48. Owsley, Struggle for the Gulf Borderlands, 193-94.

49. Wright, "A Note on the First Seminole War," 572-73.

50. Remini, Andrew Jackson and His Indian Wars, 130-32.

51. John K. Mahon, “The First Seminole War, November 21, 1817-May 24, 1818," Florida Historical Quarterly 77, no. 1 (Summer 1998): 62-67.

52. Wright, "A Note on the First Seminole War as Seen by the Indians, Negroes, and Their British Advisers," 574-75. 


\title{
Lithuania under the Soviet Occupation, 1940-41 Observations and Operations by the United States
}

\author{
Mallory Needleman
}

\begin{abstract}
Throughout World War II, an independent Lithuania was occupied three times - twice by the Soviet Union and once by Nazi Germany. During the first Soviet occupation (1940-41), the international community granted the small country support in rhetoric but little in practicality. The United States, for example, refused to acknowledge the aggressive Soviet takeover, though it refrained from providing extensive support to Lithuanian-located refugees without American citizenship. In March 1941, the U.S. Department of State sought to analyze the daily life of Sovietized Lithuania and sent John F. Mazionis through the country's closed borders. This article details power struggles within Lithuania imposed by Soviet Russia and by extension Nazi Germany.
\end{abstract}

Keywords: Soviet occupation, Second World War, U.S. foreign relations, Department of State, Lithuania, John F. Mazionis, USS American Legion (APA 17)

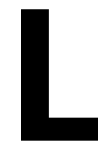

ithuania has a centuries-long history of being governed by outside forces. It was a victory, then, when it declared independence at the close of World War I, having been mercilessly ruled by both Russia and Germany consecutively since the late eighteenth century. By the mid-1920s, many consulates and legations opened in Kaunas, Lithuania's then-provisional capital,

Mallory Needleman is a graduate student at the University of Haifa and is completing her thesis, "American Intelligence Ties to Holocaust Atrocities and Cold War Operations in Lithuania: How the U.S. Dismissed Nazi Collaboration in Attempt to Defeat the Soviets." This article was made possible thanks to the author's tenure as a graduate student research fellow at the Jack, Joseph and Morton Mandel Center for Advanced Holocaust Studies, U.S Holocaust Memorial Museum. The author wishes to thank Dr. David Silberklang and Dr. Hagit Lavsky for their guidance as well as Amanda Walkins and GySgt Howard for their support. 
and its diplomats were hosted in more than 20 countries across the world. ${ }^{1}$ Lithuania's foreign relations were forming tenderly until its growing statehood was abruptly halted. On 15 June 1940, forces of the Union of the Socialist Soviet Republics (the USSR or the Soviet Union) invaded. By August, they demanded that Lithuania cut its political ties. Not even 20 years old, all diplomatic headquarters in Kaunas were to close by September. ${ }^{2}$ Lithuania fell under a ruthless Soviet authority.

For most Lithuanians, it was a triumph in 1941 when the Nazis ousted the Soviets after their violent one-year reign. In frenzied hopes to establish self-governing rule, Lithuanian political and military leaders, as well as social elites, immediately leaned into Nazi Germany's "assistance” as its new occupying power. To the chagrin of Lithuanians desperate for independence, and with the obliteration of the local Jewish population, Nazi control lasted throughout the Holocaust. The constructs of power and control by a superpower, and between superpowers, are pervasive within this time and place, and thus this article will seek to illuminate that which is often engulfed by larger stories. Simultaneously, this article brings to light the life of one man who contributed greatly to the field of American intelligence on Lithuania, through both diplomatic and military achievements, between 1940 and 1941.

This man was John F. Mazionis, who, in the summer of 1940, was a British employee of the American legation in Lithuania. That summer, he supported the extraction of American citizens from Lithuania, and then, as with other members of foreign diplomatic offices, fled Kaunas during the forced Soviet takeover and was restationed in Moscow. Mazionis reentered Lithuania from his Moscow post in early 1941 and reported on the atmosphere in Soviet-occupied Lithuania. Months later, in the summer, he began working at the American legation in Stockholm, Sweden, drafting and submitting reports on Lithuanian subversive underground movements. This article details the geopolitical power struggles within Lithuania as imposed by Soviet Russia and Nazi Germany, with Mazionis as a contextual focal point.

\section{Methodology}

This article is historical in nature, organized chronologically and thematically. This method draws a clearer picture of the personal and professional profile of John Mazionis leading up to 1940 and then delving into his activities, both overt and covert, through 1941. For Mazionis, his preserved Department of State personnel file is the only place to uncover a full profile; to date, he is named only in four academic sources. ${ }^{3}$ Geohistorically, the events of the subject matter occurred in present-day Russia, Lithuania, Sweden, and America. In an unsurprising assessment, these countries played large and antithetical roles in the Holocaust. A cross-reference of resources is conducted to the best of this 
writer's ability. In this way, attempts to obfuscate the truth by a field of study, or specific source, is countered, questioned, and noted.

\section{The Start of World War II, the Soviets, and Lithuania}

The German-Soviet Nonaggression Pact (or the Molotov-Ribbentrop Pact) was signed on 23 August 1939, five months after the Germans seized Klaipeda from Lithuania. The neutrality pact assured each party (Nazi Germany and Soviet Russia) of, as its title details, nonaggression. Also signed on this day was a protocol hidden from the public. The secret protocol, or addendum, detailed the partitioning of the Baltic States and Poland (including the reincorporation of Vilnius into Lithuania) between Soviet Russia and Nazi Germany. The original protocol was amended a month later, moving Lithuania from under Germany's purview to Russia's. ${ }^{4}$

Around this time, the United Kingdom and France granted assurances of protection to Poland. ${ }^{5}$ Germany relied on the assurances provided in the public Nonaggression Pact and invaded Poland on 1 September 1939. World War II thus began, as Germany effectively attacked the United Kingdom and France via Poland, thereby transforming life across the world. Due to the geopolitical crisis of its neighbor, Lithuania faced a humanitarian emergency of its own as refugees, Jews and non-Jews alike, fled Poland and moved into Lithuania. It was a near reversal in their historic hostilities when Lithuania agreed to support the stateless persons from Poland after the September 1939 German attackevacuees totaling more than 100,000 in all of Lithuania by $1940 .^{6}$

At the same time, Soviet troops moved into Vilnius, a territory disputed between Lithuania and Poland, though by 1939 it was under Polish authority. The Soviets took the city in accordance with the Molotov-Ribbentrop Pact. Shortly thereafter, a treaty of mutual assistance between Lithuania and the Soviet Union was signed on 10 October 1939. In this agreement, the Soviets annexed Vilnius back to Lithuania in exchange for a Soviet military presence-18,000 soldiers_-inside Lithuania's borders. ${ }^{7}$ Immediately following, bases were erected across the country, including an airbase in Paneriai (Ponary), the wooded outskirts of Vilnius. Construction included pits, roughly 15-20 meters in width and 5-6 meters in depth, excavated to house future fuel tanks for aircraft. ${ }^{8}$ Left abandoned during the Soviet retreat in June 1941, the pits converted into a necropolis for nearly 100,000 murdered Jews and others killed by gunshot at the hands of Nazis and Lithuanian collaborators during the following three years.

The Lithuanian government was not forthcoming to the public about this Soviet military occupation. In fact, it "had not prepared either militarily or morally" for such a prospect, as Lithuanian political leaders were emphatically concerned with the question of "which neighbor Lithuania should join in the 
event of a crisis." The vacillation of the leadership stifled decision making, and thus the government remained passive to the Soviet demands and complaints that grew more erratic over time. By the spring of 1940, the Soviets accused Lithuania of not only establishing anti-Soviet alliances with fellow Baltic countries but also accused Lithuanian President Antanas Smetona of hosting secret meetings with German Führer Adolf Hitler. Finally, on 25 May 1940, the Soviet Union accused Lithuania of kidnapping Soviet soldiers. ${ }^{10}$ Three weeks after the false kidnapping claims, on 14 June 1940, the Soviet Union delivered an ultimatum to Lithuania. ${ }^{11}$ Before an answer could be given, Soviet forces invaded the following day.

In one fell swoop, the Soviets breeched the Moscow Peace Treaty of 1920, the Soviet-Lithuanian Nonaggression Pact of 1926, and the Soviet-Lithuanian Mutual Assistance Agreement of $1939 .{ }^{12}$ In all, this was not an ideal situation for Lithuania, as it was slowly losing everything. In fact, under the $1939 \mathrm{Mu}-$ tual Assistance Treaty, Vilnius was not even given to Lithuania in whole; much of the territory was appropriated by the USSR, which was also in violation of the 1920 Moscow Peace Treaty. ${ }^{13}$ In a mire, President Smetona acquiesced to the June 1940 Soviet invasion and, fearing his presence in Lithuania could no longer help the country, fled to Germany hours later. ${ }^{14}$

\section{John F. Mazionis}

John F. Mazionis was born on 17 June 1907 in London to Lithuanian nationals who had recently relocated to England. After Lithuania proclaimed its independence in 1918, his parents returned to Lithuania in July 1920, residing in Kaunas with their British-born children (John and his sisters). At age 17, Mazionis dropped out of Kaunas’s Aušra Boys' Gymnasium in April 1924, having accepted a messenger position for the recently opened American consulate. ${ }^{15}$ With help from his boss at the consulate, Mazionis earned his high school diploma in 1930, despite working full time. ${ }^{16}$ Such a dual effort surely was not easy, as the consulate had 10 employees - and only one messenger. ${ }^{17}$ His role at the consulate required him to be available at all hours to complete a gamut of tasks. Robert W. Heingartner, consul to Lithuania from 1926 to 1928, kept a diary that included personal and professional commentary. According to the diary, Mazionis_-referred to at times as simply "John the messenger"—could be expected to bury the consul's dog on a summer Tuesday, retrieve and deliver diplomatic pouches on damp and dark midnights in November, and even work late nights on Sundays. ${ }^{18}$

After nearly 10 years of employment at the consulate, Mazionis demonstrated his value and was promoted to clerk. ${ }^{19}$ Mazionis was vital enough to the office that he was even included in a 1931 staff photograph (and again in 1938). ${ }^{20}$ Given a promotion in both title and salary in 1933, he could finally 
afford to enroll in college. That fall, he began attending Vytautas Magnus University (renamed from University of Lithuania). Mazionis began his tenure in 1933 as a university student while simultaneously working at the consulate. Six years later, in 1939, he graduated with a degree in economic sciences. Thus, by the time he earned his degree, Mazionis had no elaborate skills or expertise in international affairs but rather a strong work ethic, fluency in English and Lithuanian, and years of employment with the American foreign office in Kaunas.

\section{Petsamo and the USS American Legion}

By the summer of 1940, 32-year-old John F. Mazionis was a vital employee at the U.S. legation in Kaunas, serving under Minister Owen J. C. Norem (Bernard A. Gufler served as chargé d'affaires when Norem left the post on 30 July 1940), and had been promoted from clerk to managing matters of citizenship, protection, and Veterans Administration. ${ }^{21}$ His necessity bloomed under the 1940 Soviet invasion, when 102 American citizens in Lithuania needed to evacuate the newly Soviet controlled area. The region eventually became a battleground between Germany and the Soviets, as well an area in which Nazi Germany would enact its ideological aims of eradicating Jewry through any means necessary. In addition, more than 700 other American nationals in Finland, Estonia, Latvia, Sweden, Norway, Denmark, Germany, and the Netherlands - both of prominence (including foreign royalty and families of American diplomats) and of refugee status-were also in need of an escape. ${ }^{22}$

The civilians caravanned from their respective areas to Petsamo, a small area between Finland and the then-Soviet Union, that sits on the Barents Sea. There, they embarked the USS American Legion for America, which was sent from the United States for this mission. A vital conductor of this international move was none other than Mazionis, who, according to then-chargé d'affaires, Bernard Gufler, was cool, calm, courageous, and loyal. ${ }^{23}$ Notably, as he was assisting hundreds of others with their escape, Mazionis's sisters fled Lithuania for Australia on their own, thanks to their British citizenship, though Soviet authorities denied his parents, both Lithuanian nationals, permission to leave. ${ }^{24}$

As for the American Legion, unknown to its civilian passengers, the vessel secretly boarded valuable wartime cargo. In fact, it was kept secret even in the Department of State Bulletin, an official record of U.S. foreign policy, which noted only that the vessel carried passengers and nothing more. ${ }^{25}$ According to the U.S. Naval History and Heritage Command, a Swedish-made Bofors twinmount 40 millimeter antiaircraft gun was covertly placed onboard. ${ }^{26}$ While this achievement in itself was enormous, the apex was still to come.

Prior to the American Legion departing Petsamo, the United States informed Germany of its intended route and departure date to ensure its safe passage through wartime waters. Germany refused a confirmation of the American 
Legion's safe passage, offering only assurance that Germany, at the time, found no reason to be hostile - though made no promises that it would not reverse that decision. The United States, then, had to decide if the mission was safe for both the passengers and the secretly loaded weapon, which, if discovered by the Germans, would be disastrous. Ultimately, the United States proceeded with its original route without further trouble. ${ }^{27}$ The American Legion is noted as having successfully removed more than 800 civilians from battleground harm and is considered the last neutral ship to leave Petsamo during World War II. ${ }^{28}$

This logistical feat and its residual impact proved to be quite tremendous. No less than three governments in the midst of war cooperated with the U.S. government to secure the Bofors gun: the British, Swedish, and Finnish. The weapon was immediately replicated stateside and placed aboard American battleships by late 1942 . The gun significantly upgraded the antiaircraft capability of the ships of the U.S. Navy. Thus, the United States's mission success was twofold: the government safely extracted its citizens from warzones and secretly procured a weapon that was instrumental in future battle successes. ${ }^{29}$ Mazionis would later write that the achievement, as of 1953 , had yet to be equaled.

\section{Lithuania's Sovietization and the Lithuanian Activist Front (LAF)}

Up to this time, the body of the Lithuanian government, the Seimas, was a parliament comprised of multiple political party representatives. After the Soviet invasion, it was dismantled and Soviet-rigged elections replaced the multiparty parliament with strictly Communists. ${ }^{30}$ A month later, during 14-15 July, the Sovietized Seimas — renamed “The People's Diet”-assembled and, by 21 July, approved of and declared Soviet rule in Lithuania. ${ }^{31}$ Most Western nations did not recognize the annexation by the Soviets of Lithuania, including America. That July, U.S. Acting Secretary of State Benjamin Sumner Welles issued a press release declaring the United States was "opposed to predatory activities no matter whether they are carried out by the use of force or by the threat of force." ${ }^{2}$ Unfortunately, the announcement of nonrecognition did not come with much reverberating support and the Lithuanian Soviet Socialist Republic (LSSR) became part of the USSR on 3 August 1940. Thus, the limits of American principles were exposed. Lithuania quickly lost its 22-year independence and its formal international recognition was smothered by Soviet rule.

Sovietization in Lithuania ensued rapidly, and the Soviets forced Lithuania to cut all of its international ties. Following the success of the repatriation mission, diplomat Charles E. Bohlen of the U.S. embassy in Moscow arrived in Kaunas in late August. He oversaw the legation closure, as the Soviets demanded that all foreign offices in Lithuania must shutter. ${ }^{33}$ Mazionis joined Bohlen on his return to Moscow, taking with them the legation's diplomatic pouches. 
There, he worked on passport and citizenship needs under the consular section, consisting of senior staffer E. Allan Lightner Jr. ${ }^{34}$

At the same time, Lithuanian representatives were recalled from abroad. ${ }^{35}$ However, with most of the international community following a nonrecognition policy regarding Lithuania's incorporation into the USSR, Lithuania's diplomatic corps abroad retained their credentials (though they were fairly powerless), and they did their best to refuse orders from the Soviets. With the swift Soviet takeover, Lithuanians were left shocked, angry, and without a way to reckon the loss or to fight back. Michael MacQueen remarks on the problems of a Lithuanian nationalist zeal without any claim to an independent country: "Lithuania had to confront why their people had, over centuries, been swallowed up by others, and in the process nearly been eradicated as a cultural presence." ${ }^{36}$ As Lithuania underwent its rapid transformation into a Soviet Republic, some Lithuanian diplomats at posts abroad, including Lithuanian representative to Germany, Colonel Kazys Škirpa, formed a prototype government-in-exile, the National Committee. It aimed to "organize a broad anti-Soviet front" and was the precursor to what became known as the Lietuviuc Aktyvistu Frontas (the Lithuanian Activist Front, or the LAF). ${ }^{37}$

The LAF as a resistance organization against the Soviets began during a meeting between National Committee members in Škirpa's Berlin apartment on 17 November 1940. Škirpa helmed the group and, in his own words, the LAF from its start had the backing and support of the Nazis-and the German military intelligence service, the Abwehr, at that. ${ }^{38}$ The Soviets frequently arrested (and traditionally deported) anyone deemed anti-Soviet, criminal, or socially dangerous, and life under the Soviets grew exponentially erratic. Such aggression, coupled with rapid Sovietization complemented the prevalent, yet unsubstantiated, Judeo-Bolshevik myth, which encouraged a widespread antiSemitic illusion that the Jews not only controlled Lithuania but also were indivisibly united with the Soviets. ${ }^{39}$ Thus, for non-Jewish Lithuanians, a jingoist yearning for Lithuanian identity and independence festered into an underground political and social anti-Soviet, as well as anti-Semitic, movement. $^{40}$

The resistance organization was built on both passive and active resistance. This included propaganda and armed units, all established within various government and civic institutions and boasted 2,000 members at its inception. ${ }^{41}$ Between late 1940 and early 1941, the LAF's foreign-based leadership agreed that a revolt was to occur when its leadership determined that conditions were right. ${ }^{42}$ To achieve this goal, they collected arms, made plans, and absorbed armed resistance units. Moreover, the LAF's propaganda became "saturated" with Nazi-style anti-Semitism. ${ }^{43}$ In fact, on behalf of the LAF, Škirpa argued to Nazi leadership in Berlin that it was in Germany's interest to "sponsor an 
anti-Bolshevik national liberation movement and a restored Lithuanian state." ${ }^{44}$ They saw Nazi Germany as the only power capable of defeating their occupier, the Soviet Union, and hoped that opportunities to reestablish an independent Lithuania might arise.

In December 1940, the LAF distributed within Lithuania about 800 copies of a leaflet titled "From Bolshevik Slavery to a New Lithuania" ("Iš bolševikinès vergijos i naujają Lietuvą"). The content included a list of problems inside Lithuania, including the complaint that under Lithuanian independence, Jews were not restrained (pazaboti). ${ }^{45}$ Historian Saulius Sužiedelis remarks that Bronys Raila, the LAF's chairman of propaganda, complained, "the countless 'Jewish breed,' coddled by [President Antanas] Smetona, had made Lithuania one of the most Jewish states in Europe." He called for a state purified of "Jews, parasites, and traitors" and declared that the LAF "is determined to completely separate the Jews from the Lithuanian state." 46 On 24 March 1941, the LAF disseminated their "Directives for the Liberation of Lithuania" across the country: "We must create an atmosphere that is so stifling for the Jews that not a single Jew will think that he will have even the most minimal rights or possibility of life in the new Lithuania." ${ }^{47}$

\section{Lithuania in March 1941: An American Diplomat's Report}

In Moscow, Mazionis was assisting with visas in the consular section, which was managed by Lightner. Lightner later remarked that they "had lots of business with the Russian foreign office to try to make arrangements to get people out [of Russia]," which included, in his words, "horse trading." 48 In one anecdote, to secure exit permits for those with American citizenship, their office withheld entry visas for Russian technicians who needed to leave for training in the United States. He recalls explaining to the Soviets' office, “'[W] e are extremely busy these days and just haven't been able to get around to it, but if you could possibly manage to answer our notes 15 through 35 with respect to the Americans waiting to visit the Embassy, it might help us to get to the visa cases.' The effect was magical." ${ }^{49}$ In another example, the deft diplomat used his skills to again benefit the American office and Department of State at large that, six months into the Soviet invasion, still had no ear to the ground regarding the occupied areas. This included Lithuania, which by then was boasting a homegrown, foreign organized, anti-Semitic, and anti-Soviet movement, the LAF.

Mazionis, having left his parents in Lithuania (who, by 1941, were aged and ill), notes he was eager to visit. He writes in 1953, "Upon my request and with the strong and repeated demarches by the Chief of the Embassy Consular Section [Lightner], at the Soviet Foreign Office, I was eventually granted permission by the Soviet government to visit my parents in Lithuania." ${ }^{50}$ In 
these horse trading deals, Lightner managed to negotiate Mazionis's return to the country, resulting in yet another twofold success for Mazionis (the first being the Petsamo mission): he not only visited his parents, a perfect cover and personal comfort but also completed an intelligence-gathering mission within heavily shrouded Lithuania. Despite being watched and followed by the Soviets during his stay, Mazionis used his Lithuanian acquaintances in the press and within various walks of life to gain a clear understanding of the situation in Lithuania at the time. ${ }^{51}$

Mazionis traveled to Kaunas, and may have gone to Vilnius, given the details of his report. He explicitly describes the "large gasoline tanks," which were in the process of being installed underground in many parts of the country. ${ }^{52}$ This included Vilnius, where they were later used for mass murder under Nazi occupation. In terms of his sources, they were predominantly members of subversive underground organizations; they were versed in the political and social environment of the local populace-in other words, he very likely met with LAF members. He names their Berlin-based leadership and details their roles, including Škirpa ("the strong man"). He even compliments their "extensive system of espionage." 53 Relying on his experience and sources, he writes that the local populace resented the Soviet occupation and blamed the local Jewry for many ills.

His report features so much anti-Semitism that it is perhaps difficult to say if his personal beliefs influenced his reporting, or if he was reporting on experiences as matters of fact. He uses gross generalizations to describe the Jewish population on the first pages alone. ${ }^{54}$ They are the "strongest" supporters of the Soviets, they are the "wealthiest" in Lithuania, and "[a]ll the shops in Kaunas have Jewish commissars" whose employees are predominantly Jewish. He writes that the hatred of the "Reds" is "deep" with Lithuanians— so much so, that even teenage boys carry pistols (to fight the Soviets, who apparently are supported strongly by the Jews). Mazionis also comments that the Jewish population comprises about 7-8 percent of the population in total, essentially suggesting there is a disproportionate amount of employed (wealthy) Jewish merchants to regular Lithuanians. He concludes by writing, "the new regime is usually described as 'the Jewish Government', thus doubling down on the pervasive Judeo-Bolshevik myth. ${ }^{55}$

Shortly after the visit, upon his return to Moscow, Mazionis submitted a report dated 22 March 1941 on "the situation in Lithuania" through his superiors at the Office of the Secretary of State. Its contents were, and are, so valuable to understanding Lithuania during this tumultuous time that it was published 54 years later for public consumption and historical considerations. ${ }^{56}$ The report was as necessary as it was robust, and for this, Walter C. Thurston, minister counselor of the embassy in the Soviet Union, told Mazi- 
onis that the State Department "appreciated highly" the information submitted. ${ }^{57}$ This compliment is the only identifiable direct product of the report; to date, no other operations or inquiries were conducted by the State Department (or any other U.S. government office) as a result of Mazionis's findings. The indirect historical value of his report is that, as is now known, it was a dark foreshadowing of later events.

By the summer of 1941, Mazionis finished his time in Moscow. He, along with two other clerks, took holiday leave to Stockholm, which proved to be permanent. ${ }^{58}$ They left Moscow on 19 June. At the same time, Lithuania was ripe for a contentious, and even predictable, explosion. Mazionis's report in March predicted this suspense: "The general spirit of the people is one of expectancy and eagerness for war between the Soviets and the Nazis. Although the people desire to see the Germans in Lithuania instead of the Reds." ${ }^{59}$ He stresses that locals hoped "Lithuania may arise again as an independent state." ${ }^{60}$ The expected war arrived in June-though not before massive arrests and deportations by the Narodnyi Komissariat Vnutrennikh Del (People's Commissariat for Internal Affairs, NKVD) spread raucously across Lithuania. Between 15,851 and 20,000 people labeled "anti-Soviet elements" (men, women, and children) were rounded up and deported in cattle cars, predominantly to Siberia. ${ }^{61}$

The deportations pushed an anxious society toward catastrophe; the terror they created convinced Lithuanians that the country was facing imminent destruction. ${ }^{62}$ The colossal expulsions by the Soviets cemented local rancor and hostilities against Jews, as Lithuanians cemented their affiliation of Jews with the Soviet oppressors. Jews were blamed for everything: "Sovietization, arrests of Lithuanians, destruction of the army, separation of the Catholic Church from the State." ${ }^{63}$ Just days before the Nazi invasion, the LAF published another statement, harkening back to their March 1941 proclamation, as well as (unknowingly at the time) Mazionis's secret report:

The crucial day of reckoning has come for the Jews at last. Lithuania must be liberated not only from the Asiatic Bolshevik slavery but also from the Jewish yoke of long standing. . . . All Jews, without any exception, are strictly ordered to immediately leave Lithuania. ${ }^{64}$

How they were to leave Lithuania remained ambiguous, but the overall message was clear.

The Nazi sortie into Lithuania was the beginning of Operation Barbarossa, the premeditated German military attack into the eastern front that breached the 1939 Molotov-Ribbentrop Pact. At the time of the June 1941 offensive, an estimated 203,000-207,000 Jews lived in Lithuania, including the recently annexed Vilnius region. ${ }^{65}$ By that December, a mere 43,000 Jews remained. ${ }^{66}$ The 
striking drop in population between June and December 1941 was fundamentally due to mass murder perpetrated by the Nazis and their local collaborators.

The Jewish population's dramatic plummet stresses the actions, and their consequences, of local Lithuanians throughout the Holocaust. However, causation also can be rightfully attributed to, in part, the superpowers of the milieu-both in exploitations (by the Soviet Union and, later, Nazi Germany) and diminutive execution (the United States). In less than three years (193941), ideology and politics metastasized in the Lithuanian consciousness, and materialized as a tangible and concrete warzone. The power struggles within Lithuania as imposed by Soviet Russia and Nazi Germany, with Mazionis as a contextual focal point, offers historical insight to the confined time of the first Soviet occupation, but can also be considered supplemental evidence of the often unintended destructive path that can emerge if an entity, particularly a superpower, abuses the theoretical and literal uses of its authority.

\section{Notes}

1. Alfred Erich Senn, "The Formation of the Foreign Office, 1918-1921," Slavic Review 21, no. 3 (September 1962): 507, https://doi.org/10.2307/3000451.

2. "Diplomatic Signs in Kaunas City, 1919-1940" [Diplomatijos ženklai Kauno mieste 1919-1940 m.], Diplomatinis Kaunus, last accessed 19 October 2018. An interactive map, newly released by the Lithuanian government, showcases diplomatic offices in Kaunas between 1919 and 1940. This is one of few sources to identify which offices were forcibly closed by the Soviets. They include the United States, Sweden, Argentina, Hungary, France, Spain, the United Kingdom, the Netherlands, Denmark, Finland, Norway, Latvia, Estonia, and Italy. Others, such as Czechoslovakia, Belgium, and Poland, closed earlier.

3. In a scheduled file destruction, National Archives and Records Administration (NARA) destroyed administrative files of 1912-35 for foreign-located U.S. offices, eradicating most other primary sources regarding Mazionis's time in Kaunas.

4. V. Stanley Vardys and Judith B. Sedaitis, Lithuania: Rebel Nation (Boulder, CO: Westview Press, 1997), 46-47.

5. "The British War Bluebook: Agreement of Mutual Assistance between the United Kingdom and Poland-London, August 25, 1939," Avalon Project-Yale Law School, last accessed 18 October 2018.

6. Tomas Balkelis, "War, Ethnic Conflict and the Refugee Crisis in Lithuania, 19391940," Contemporary European History 16, no. 4 (November 2007): 463-62, 466, 471, https://doi.org/10.1017/S0960777307004122; and Andrzej Żbikowski, "Poles and Jews in the Vilnius Region in 1939-1941," Darbai ir dienos [Deeds and days], no. 67 (2017): 151-61, http://dx.doi.org/10.7220/2335-8769.67.7.

7. Bronis J. Kaslas, "The Lithuanian Strip in the Soviet-German Secret Diplomacy, 1939-1941," Journal of Baltic Studies 4, no. 3 (Fall 1973): 216, https://doi.org/10 $.1080 / 01629777300000241$. Gen Stasys Raštikis, delegate for Lithuania in the negotiations, denies that Vilnius was a trade for Soviet bases. He maintained Vilnius was returned to Lithuania as per the Treaty of Versailles in 1920, and that the guise of any Soviet benevolence should be recognized as incorrect. See Constantine R. Jurgela, Lithuania: The Outpost of Freedom (National Guard of Lithuania in Exile, 1976), 186-87.

8. Ernst Klee, Willi Dressen, and Volker Riess, eds., "The Good Old Days": The Holocaust as Seen by Its Perpetrators and Bystanders (Old Saybrook, CT: Konecky \& Konecky, 1988), 42.

9. Alfonsas Eidintas and Vytautas Žalys, Lithuania in European Politics: The Years of the First 
Republic, 1918-1940, ed. Edvardas Tuskenis (New York: St. Martin’s Press, 1997), $180-81$.

10. Vardys and Sedaitis, Lithuania, 47.

11. Thomas Remeikis, "The Decision of the Lithuanian Government to Accept the Soviet Ultimatum of June 14, 1940," Lituanus 21, no. 4 (Winter 1975).

12. For an in-depth publication on the first months of the occupation, see Algirdas Jakubcionis, Stasys Knezyz, and Arūnas Streikus, Occupation and Annexation: The First Soviet Occupation (1940-1944), vol. 1, The Crimes of the Totalitarian Regimes in Lithuania (Vilnius, Lithuania: Margi Rastai, 2006).

13. Jurgèla, Lithuania, 197.

14. Eidintas and Žalys, Lithuania in European Politics, 182-83; and Alfonsas Eidintas, Antanas Smetona and His Lithuania: From the National Liberation Movement to an Authoritarian Regime (1893-1940), trans. Alfred Erich Senn (Leiden, Netherlands: Rodopi, 2015), 126-27, https://doi.org/10.1163/9789004302044.

15. "John F. Mazionis, Personnel File, 1953," Application and CV for Civil Employment, Record Group 59, General Records of the Department of State, National Archives, Washington, DC.

16. He notes only a single "Principal Officer," but, between 1924 and 1930, there were three changes of authority: Harry E. Carlson (1924-26), Robert W. Heingartner (1926-28), and Hugh S. Fullerton (1928-32).

17. Robert W. Heingartner, "Prologue: A Letter from Harry Carlson, the American Consul in Kaunas, to Robert W. Heingartner," in Lithuania in the 1920s: A Diplomat's Diary (Amsterdam: Rodopi, 2009), 11.

18. Heingartner, Lithuania in the 1920s, 161, 188, 219.

19. Hugh S. Fullerton published a fascinating article on Lithuania, and the U.S. consulate-legation between the 1920s and 1930s. Hugh S. Fullerton, "Lietuvos Respublikos," American Foreign Service Journal (May 1933): 166-70.

20. Fullerton, "Lietuvos Respublikos." The U.S. Embassy in Lithuania prominently displays the photograph on its website, last accessed 19 October 2018. See "History of the U.S. and Lithuania," U.S. Embassy in Lithuania. For the 1938 photograph, see the American Foreign Service Journal 15, no. 4 (April 1938): 240.

21. The offices of the U.S. representation in Kaunas changed from consulate to legation on 31 May 1930.

22. Crown Princess Martha of Norway, as well as Bernard Gufler's wife and children.

23. "John Mazionis, Personnel File, 1953," Letter from Gufler to Mazionis, General Records of the Department of State, National Archives, Washington, DC.

24. "John Mazionis, Personnel File, 1953," Application and CV for Civil Employment.

25. "Repatriation of American Citizens," Department of State Bulletin 3, no. 60 (17 August 1940): 115 .

26. “American Legion (AP-35), 1941-1946," Naval History and Heritage Command, 28 November 2017.

27. "Note to Germany on the Course of the 'American Legion'," Department of State Bulletin 3, no. 61 (24 August 1940): 152-54.

28 "American Legion (AP-35), 1941-1946."

29. "Note to Germany on the Course of the 'American Legion'," 152-54.

30. Vardys and Sedaitis, Lithuania, 52.

31. Eidintas and Žalys, Lithuania in European Politics, 185; and Karen Sutton, The Massacre of Jews in Lithuania (Jerusalem, Israel: Gefen Publishing House, 2008), 81-83.

32. "Welles Declaration, Department of State Press Release, 'Statement by the Acting Secretary of State, the Honorable Sumner Welles', 23 July 1940, History and Public Policy Program Digital Archive, NARA, RG 59, accessed 19 October 2018.

33. Bohlen was restationed to Tokyo immediately after. "The Foreign Service Personnel Changes," Department of State Bulletin 3, no. 63 (30 November 1940): 467. Although inaccessible to this writer, Bohlen's memoir likely illuminates this time. Charles E. Bohlen, Witness to History, 1929-1969 (New York: W. W. Norton, 1972).

34. " "John Mazionis, Personnel File, 1953." 
35. Foreign Relations of the United States Diplomatic Papers, 1940, General, vol. 1, ed. Matilda F. Axton and Shirley L. Phillips (Washington, DC: Government Printing Office, 1959), Document 427.

36. Michael MacQueen, "The Context of Mass Destruction: Agents and Prerequisites of the Holocaust in Lithuania," Holocaust and Genocide Studies 12, no. 1 (Spring 1998): 27-28, https://doi.org/10.1093/hgs/12.1.27.

37. Eidintas, Antanas Smetona and His Lithuania, 128.

38. "From K. Škirpa's Notes about the Foundation of the LAF and Its Links with Nazi Organizations," in Documents Accuse, comp. Boleslovas Baranauskas and Kazys Rukšènas, ed. E. Rozauskas, trans. L. Valeika and A. Aukštikalnienė (Lithuanian), trans. Vl. Grodzenskis (German), English version ed. Vl. Grodzenskis (Vilnius, Lithuania: Gintaras, 1970), 66-67.

39. Eidintas, Jews, Lithuanians and the Holocaust, 162; Dieckmann and Sužiedelis, The Persecution and Mass Murder of Lithuanian Jews during Summer and Fall of 1941, 101; and MacQueen, "Mass Destruction," 35.

40. Stasys Zymantas (Žakevičius), "Lithuania Militants," Lituanus 2, no. 7 (June 1956).

41. Arūnas Bubnys, Lietuviu antinacine rezistencija, 1941-1944 $m$ [Nazi resistance movement in Lithuania, 1941-1944], trans. Vijole Arbas (Vilnius, Lithuania: VAGA, 2003), 47.

42. Algirdas Martin Budreckis, The Lithuanian National Revolt of 1941 (Boston, MA: Lithuanian Encyclopedia Press, 1968), 35.

43. Joseph Levinson, ed., The Shoah (Holocaust) in Lithuania (Vilnius, Lithuania: Vilna Gaon Jewish State Museum, 2006), 163.

44. Saulius Sužiedèlis, "Lithuanian Collaboration during the Second World War: Past Realities, Present Perceptions," in Kollaboration in Nordosteuropa: Erscheinungsformen Und Deutungen Im 20. Jahrhundert, ed. Joachim Tauber (Wiesbaden, Germany: Harrassowitz, 2006), 148; and "Memorandum by the Head of Political Division (Doc \#650, 321/193369-70)," in Documents on German Foreign Policy, 1918-1945. Series D (1937-1945), vol. 12, The War Years: February 1-June 22, 1941 (London: Her Majesty's Stationery Office, 1962), 1054-55.

45. Kazys Škirpa, Sukilimas Lietuvos Suverenumui Atstatyti Dokumentine Apžvalga [Uprising for the restoration of Lithuania's sovereignty] (Washington, DC: privately published, 1973), 123.

46. Sužiedèlis, "Lithuanian Collaboration during the Second World War," 149. See also "Foreign Saviors, Native Disciples: Perspectives on Collaboration in Lithuania, 19401945," in Collaboration and Resistance during the Holocaust: Belarus, Estonia, Latvia, Lithuania, ed. David Gaunt, Paul A. Levine, and Laura Palosuo (Bern, Switzerland: Peter Lang, 2004), 333-41.

47. In 1991-92, during an interview published across a few issues of a Lithuanian magazine, Saulius Sužiedelis announced the discovery of an original copy of the "Directives" inside the Edvardas Turauskas Papers, Hoover Institution Library. See "1941 Metų Sukilimo Baltosios Dèmès. Pokalbis Su Sauliumi Sužiedèliu," Akiračiai 233, no. 9 (1991): 6-7; 234, no. 10 (1991): 8-9; and 235, no. 1 (1992): 8-10. A copy of the document is reprinted in Liudas Truska and Vytautas Vareikis, The Preconditions for the Holocaust: Anti-Semitism in Lithuania, Second Half of the 19th Century-June 1941, vol. 1, The Crimes of the Totalitarian Regimes in Lithuania: The Nazi Occupation (Vilnius, Lithuania: Margi Raštai, 2004), 245. The document itself is located in the Edvardas Turauskas Papers, Hoover Institution Library, CSUZ 75015-A, Box 5, "Lietuvai išlaisvinti nurodymai," 24 March 1941.

48. E. Allan Lightner Jr., interview with Richard D. McKinzie, Oral History transcripts, 26 October 1973, Harry S. Truman Presidential Library and Museum, Washington, DC, 26, hereafter Lightner interview.

49. Lightner interview, 26-28.

50. "John Mazionis, Personnel File, 1953," Application and CV for Civil Employment.

51. "John Mazionis, Personnel File, 1953," Application and CV for Civil Employment.

52. Senn, "Lithuania in March 1941," 153. 
53. Senn, "Lithuania in March 1941," 157.

54. Senn, "Lithuania in March 1941," 153.

55. Senn, "Lithuania in March 1941," 153.

56. Senn, "Lithuania in March 1941," 153.

57. "John Mazionis, Personnel File, 1953," Application and CV for Civil Employment.

58. "John Mazionis, Personnel File, 1953," Application and CV for Civil Employment.

59. Senn, "Lithuania in March 1941," 155.

60. Senn, "Lithuania in March 1941," 154. Christoph Dieckmann and Saulius Sužiedèlis concur: "For many Lithuanians, the only realistic hope for liberation from Stalin's tyranny lay in a Soviet-German conflict." Christoph Dieckmann and Saulius Sužiedèlis, The Persecution and Mass Murder of Lithuanian Jews during Summer and Fall of 1941 (Vilnius, Lithuania: Margi Raštai, 2006), 3:98.

61. Anton Weiss-Wendt and Uğur Ümit Üngör, "Collaboration in Genocide: The Ottoman Empire 1915-1916, the German-Occupied Baltic 1941-1944, and Rwanda 1994," Holocaust and Genocide Studies 25, no. 3 (2011): 435n81, https://doi.org/10.1093/hgs /dcr057; and Eugenijus Grunskis, Lietuvos gyventoju tremimai 1940-1941, 19451953 metais [The deportations of Lithuania's inhabitants, 1940-1941, 1945-1953] (Vilnius, Lithuania: Pasaulio Lietuviu Bendromene, 1996), 38-53.

62. Weiss-Wendt and Üngör, "Collaboration in Genocide," 420.

63. Alfonsas Eidintas, Jews, Lithuanians and the Holocaust, trans. Vijole Arbas and Edvardas Truskensis, 2d ed. (Vilnius, Lithuania: Taurapolis, 2012), 145.

64. Jürgen Matthäus, "Key Aspects of German Anti-Jewish Policy," Lithuania and the Jews: The Holocaust Chapter, Symposium Presentations (Washington, DC: United States Holocaust Memorial Museum Center for Advanced Studies, 2004), 18; and Documents Accuse, 124-25.

65. Yitzhak Arad, "The Murder of the Jews in German-Occupied Lithuania," in The Vanished World of the Lithuanian Jews, ed. Alvydas Nikžentaitis, Stefan Schreiner, and Darius Staliūnas (Amsterdam: Rodopi, 2004), 176.

66. Arūnas Bubnys, "The Holocaust in Lithuania: An Outline of the Major Stages and Their Results," in The Vanished World of the Lithuanian Jews, 212. 


\title{
Evaluating Russian Strategy in Its Near Abroad A Comparison of the Conflicts in Georgia and Ukraine
}

\author{
First Lieutenant Michael Auten
}

Abstract: Since the turn of the millennium, Ukraine and Georgia have experi-
enced reform movements aimed at rooting out corruption and integrating with
Western institutions. Unfortunately, both also suffered wars with Russia intended
to stifle their democratic aspirations. Although both conflicts were precipitated
under different conditions, there may be some useful conclusions to be drawn
from a comparison of the two. If the United States is to continue to support se-
curity in Europe, we must understand Russia's strategy, and both the Georgian
and Ukrainian conflicts provide a critical window into the Russian approach.

Keywords: Russia, Georgia, Ukraine, hybrid war, North Atlantic Treaty Organization, NATO, European Union, Eastern Europe, EU, little green men, color revolutions, Maidan Revolution, Euromaidan, Orange Revolution, Rose Revolution, Mikheil Saakashvili, Petro Poroshenko, Viktor Yanukovych, separatism, Crimea, Donbass, Luhansk, Donetsk, Abkhazia, South Ossetia, Vladimir Putin

I

n February 2014, the world watched with a mixture of horror and awe as Ukraine, geographically the largest country within continental Europe and a historic gateway between East and West, underwent a deadly revolution.

1stLt Michael Auten was commissioned into the Marine Corps in 2016 after graduation from the U.S. Military Academy at West Point, where he participated in foreign military academy exchange programs in Kazakhstan and the Republic of Georgia. Following graduation, he accepted a Fulbright Fellowship to study abroad in Ukraine for one year. There, he received an MA in economics and saw firsthand the application of security policy in Eastern Europe. After his return, Auten graduated from The Basic School, Marine Corps Base Quantico, VA, and was designated a communications strategy and operations officer. Due to his experience in Ukraine, he was chosen as an experience-track foreign area officer for Eurasia in May 2018.

MCU Journal vol. 9, no. 2 
It resulted in the overthrow of its authoritarian president and the installation of a reform-minded, Western-looking regime. Amid the chaos in Kyiv's central square, Russian proxy forces began to appear in Crimea and eastern Ukraine. ${ }^{1}$ Taking advantage of preformed misconceptions about the Ukrainian government and appealing to a pan-Slavic, anti-Western, Russo-centric cultural identity, Russia and its proxies illegally annexed Crimea and instigated a war that has claimed more than 10,000 lives and that continues today. ${ }^{2}$ Outright conflict on the doorstep of NATO has increased tensions in the region and caused Estonia, Latvia, Lithuania, and Poland to request an increased presence from their NATO allies. ${ }^{3}$ The conflict in Ukraine has clear repercussions for the security regime that the United States and its allies have painstakingly constructed in the decades following World War II. Secretary of Defense James N. Mattis, in a 2018 speech, noted the threat:

We see the Russian Federation as the nation closest to us in nuclear parity, and [it has] proven willing to use conventional and irregular power in violation of international norms. For the first time since World War II, Russia has been the nation that has redrawn international borders by force of arms in Georgia and Ukraine, while pursuing veto authority over their neighbors' diplomatic, economic and security decisions. ${ }^{4}$

Russia's actions in Ukraine were a surprising breach of international law, and as Secretary Mattis notes, Ukraine is not the only recent victim of Russian ambitions. Russia instigated a similar conflict in Georgia in 2008, and it has pursued a strategy of expansion since at least 2004. The tactics employed by the Russians in Georgia were then refined and reapplied, to much greater effect, in Ukraine. To obtain a more holistic view of Russia's strategic direction, we must thoroughly examine the conflicts that have defined its path in recent history. Comparing both conflicts may provide valuable insights and allow us to come to accurate and useful conclusions regarding the ongoing struggle for stability and security in both NATO's European member states and Eastern Europe as a whole.

This article provides a brief history of the Georgian and Ukrainian conflicts. Then, it will explore the ways in which the conflicts differ and the implications of those differences. Finally, the article will offer a broader analysis of Russian strategy in its near abroad and a projection of its future strategies. ${ }^{5}$

\section{The Ukrainian Conflict}

Ukraine is a diverse country with a tumultuous history. The landmass of modern-day Ukraine has been part of several different empires, and although the country has not been independent for more than 40 years in its entire his- 
Map 1. Map of modern-day Ukraine

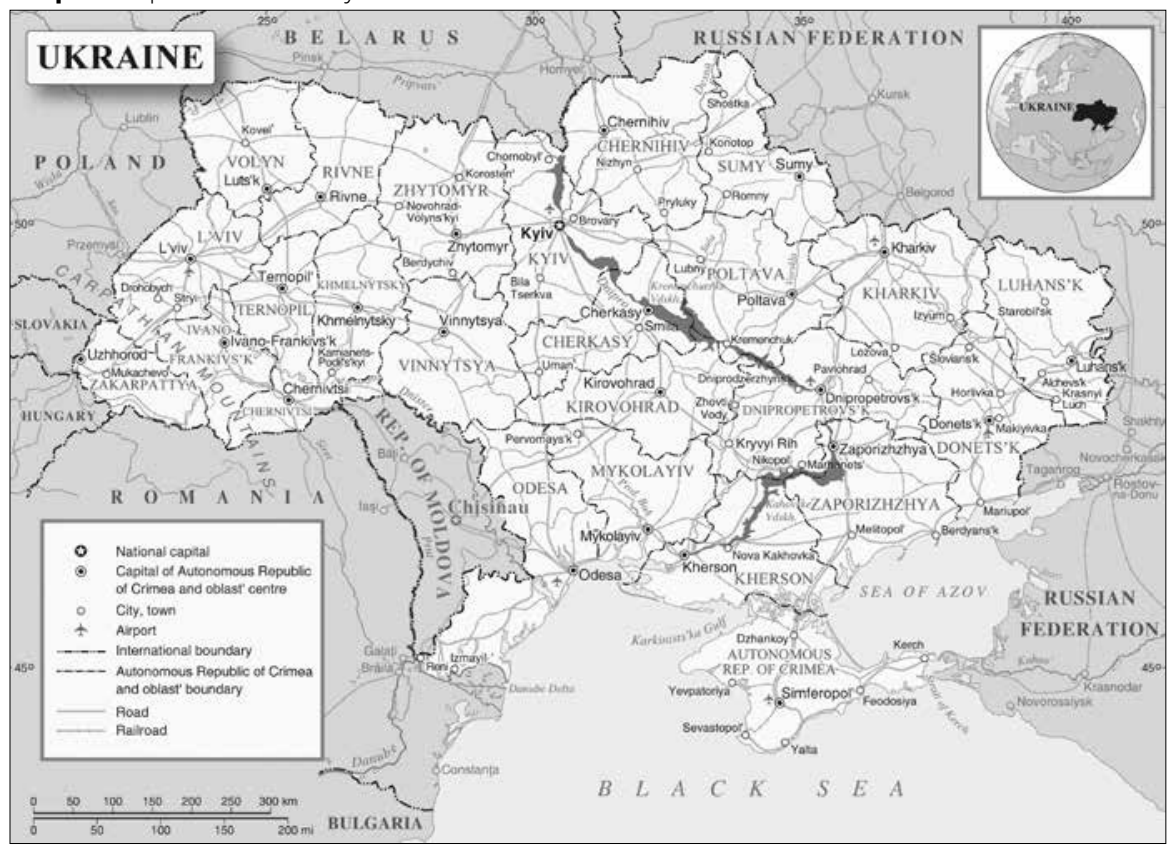

Source: courtesy of On the World Map, adapted by MCUP.

tory, its central role in European and Eurasian history cannot be overlooked. The modern conflict in Ukraine is both a consequence and a casualty of the turbulent history that brought it to its current station.

The Slavic peoples of the Dnieper River lived in small, fragmented communities for many years, but the arrival of the Vikings in the eighth century brought a governing structure to the land for the first time. The Viking state created in Ukraine eventually became one of the most powerful early medieval European states, Kyivan Rus' . ${ }^{6}$ Modern-day Ukrainian activists often refer to Kyivan Rus' to underline the historical importance of Ukraine. Following the dissolution of Rus' in the twelfth century, Ukraine's lands shuffled hands between the rulers of the Golden Horde, Lithuania, Poland, the Polish-Lithuanian Commonwealth, and the Crimean Khanate. The 1654 Pereyaslav Agreement sealed Ukraine's fate as a country divided between Russia in the east and Poland in the west. ${ }^{7}$ With the border cleanly demarcated by the Dnieper River, many of Ukraine's modern-day frustrations arise from the centuries of separation that began after the Pereyaslav Agreement (map 1).

The modern history of Ukrainian independence begins with the fall of the Russian monarchy in 1917. As the Bolsheviks and Mensheviks fought for control of Moscow, Ukraine gained its independence for a brief period. ${ }^{8}$ However, after Bolshevik consolidation in the Kremlin, war came to Ukraine, this time to ensure Russia's neighbor would cooperate with the political changes sweeping 
the country. As a result, the Ukrainian state merged with the Soviet Union, becoming one of its founding members. ${ }^{9}$ Soviet promises to uphold Ukrainian culture were quickly forgotten as Russification became policy in the 1930s. Then, Holodomor, a man-made famine caused by Soviet policy during the shift to Russification, claimed the lives of between 2.5 and 7.5 million Ukrainians. ${ }^{10}$ Ukrainian nationhood continued to be subjugated throughout Soviet rule. After the dissolution of the union in 1991, Ukraine finally received its independence. ${ }^{11}$ In the 1991 referendums for independence, there was broad support throughout the mainland for separation from the Soviet Union. The situation in Crimea was more complicated, as Crimean authorities initially declared their independence from Ukraine then immediately amended the constitution to declare the peninsula a largely autonomous region of Ukraine. Crimea's legal status was finally settled in 1998 as the Ukrainian parliament ratified a version of the Crimean constitution that surrendered more control to Kyiv. ${ }^{12}$

The current conflict is the second of two major political movements that swept Ukraine in the period following Soviet rule. In 2004, hundreds of thousands of Ukrainian protesters came to Kyiv's central square, Maidan Nezalezhnosti (Independence Square), to protest the fraudulent election of the prime minister and heir apparent to the Kuchma regime, Viktor Yanukovych, to the office of president. The nonviolent Orange Revolution, as it came to be known, was successful, and a second round of elections found Viktor Yushchenko victorious. However, political infighting between Yushchenko and Yuliya Tymoshenko, his prime minister, destroyed the political alliance that rose to power in the revolution. Capitalizing on the weaknesses of the pro-European coalition, Yanukovych was then reelected in the presidential race of $2012 .{ }^{13}$ In the 2014 crisis, rising doubt in the regime of Viktor Yanukovych again came to a head as he refused to sign an association agreement with the European Union (EU). A small student-led protest arose in Kyiv's central square, but when the protesters were brutally beaten by the police, the movement grew exponentially until hundreds of thousands of protesters marched on the streets in late November.

Although the protests started as a response to the decision not to sign the association agreement, they became more generally focused against Yanukovych and his corrupt practices. As more protesters joined the movement, Ukrainian security forces continued employing heavy-handed tactics, shocking many in both Ukraine and the Western world. This eventually gave way to outright revolution, as the streets of Kyiv became the site of daily clashes between police and protesters. The situation came to its conclusion on a cold night in February, when the disgraced president fled the country after his security forces unleashed a murderous force of snipers on unarmed protesters the previous day, killing dozens. ${ }^{14}$ 
Map 2. Ukraine contact line as of October 2016

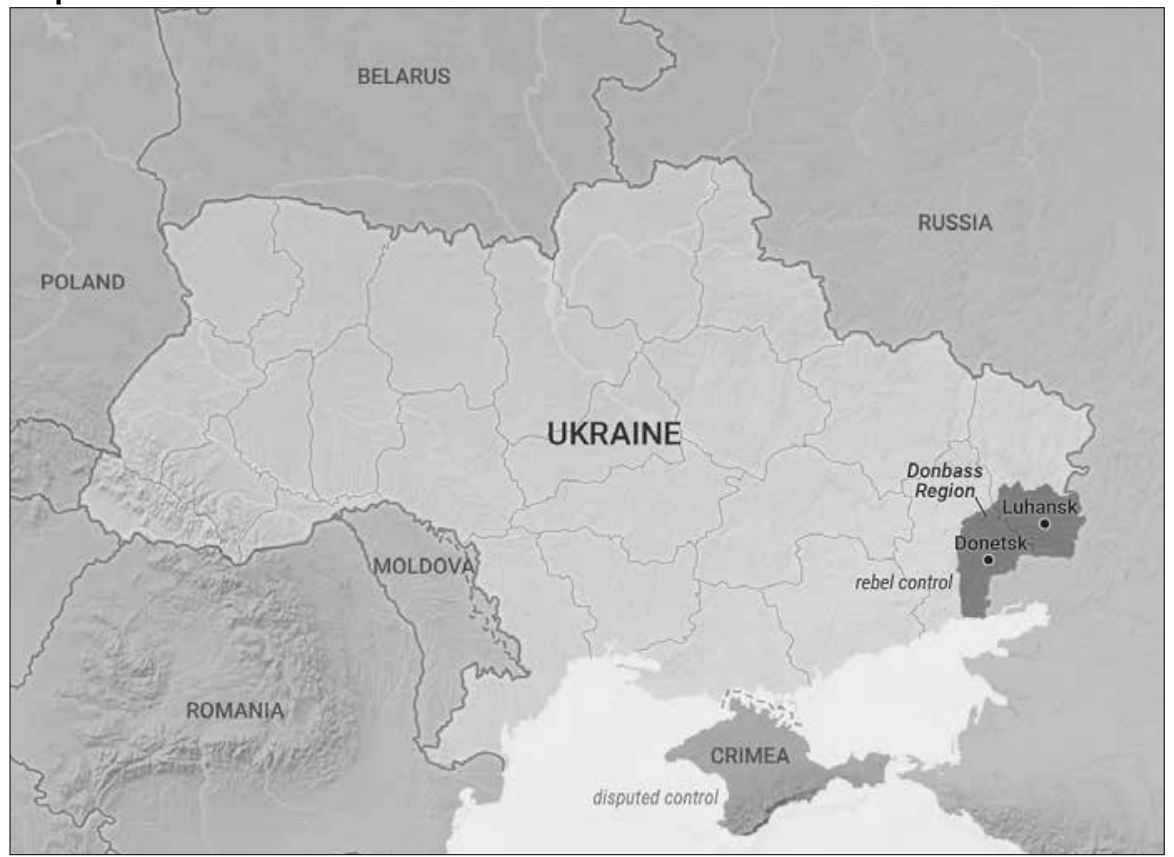

Source: courtesy of Ministry of Defense, Ukraine, adapted by MCUP.

As Kyiv was dealing with revolution and the world was watching the Sochi 2014 Winter Olympics, soldiers in Russian military camouflage, yet without insignia, quietly began to infiltrate key government structures in Crimea, and Russian disinformation began to stoke anti-Ukrainian sentiment in the eastern portion of the country. ${ }^{15}$ Before the end of the crisis, Russia would illegally annex Crimea with the help of irregular military forces supported by the Russian naval base in Sevastopol, and the situation in eastern Ukraine would devolve into war. Independent reporting and analysis confirmed the presence of Russian troops and military equipment in eastern Ukraine, and in 2015, analysts placed the number of Russian troops in the country at approximately 12,000 (map 2). ${ }^{16}$

The front line of the war in eastern Ukraine went as far west as Mariupol, a prominent Ukrainian port city, but eventually stalemated at a line roughly coincident with the capital cities of Donetsk and Luhansk late in $2014 .{ }^{17}$ While the international community brokered a number of cease-fire agreements, fighting still intermittently rages along the contact line. An independent monitoring mission commissioned by the Organization for Security and Co-operation in Europe (OSCE) has estimated that there have been more than 35,000 casualties, including more than 10,000 deaths, both civilian and military. ${ }^{18}$ 
Map 3. Modern-day Georgia

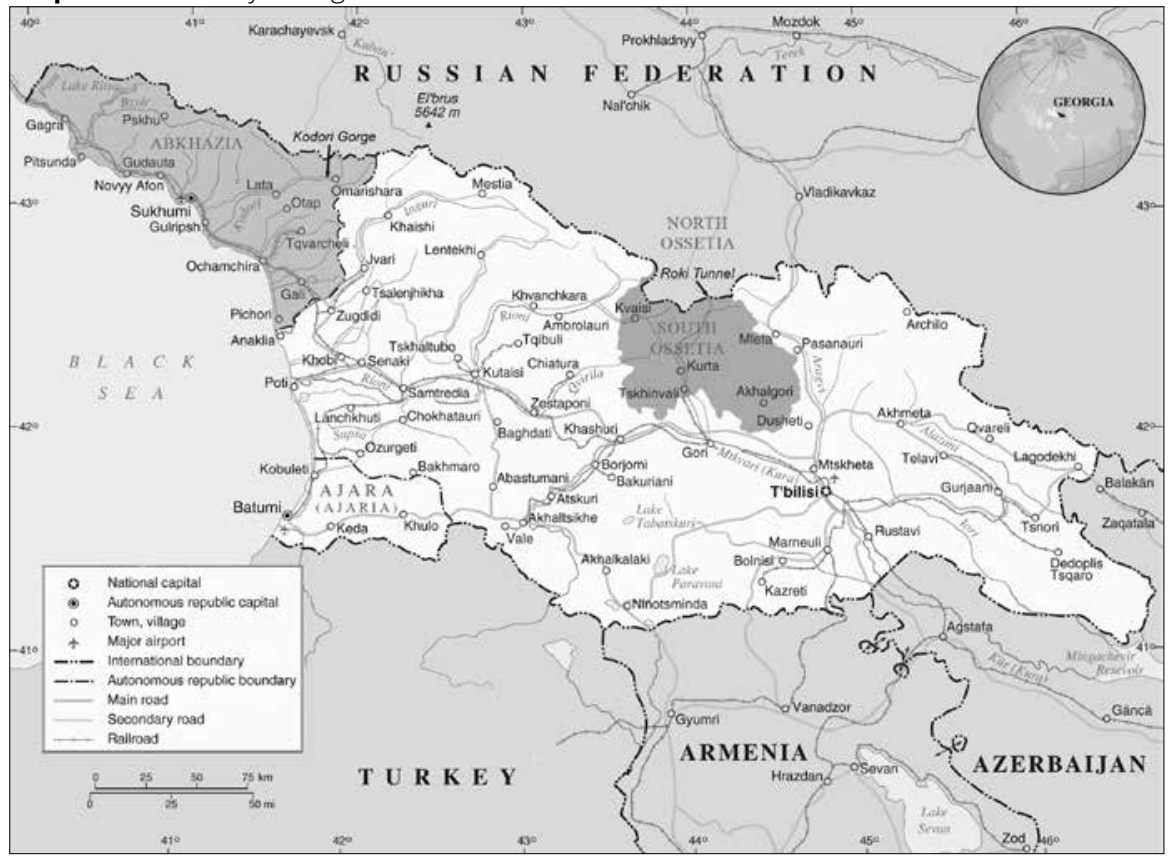

Source: courtesy of United Nations Cartographic Section, adapted by MCUP.

\section{The Georgian Conflict}

The Republic of Georgia is a small country in the Caucasus mountains (map 3). Nestled into a beautiful mountain range well-known for skiing and wine production, the country has been a vacation destination of Russia's most influential businessmen and politicians throughout much of the twentieth and twenty-first centuries. Joseph Stalin himself was Georgian, and international condemnation of his actions has not completely penetrated his native land. Even today, there is a museum to Stalin in his mountainous Georgian hometown, Gori. Ironically, it lies only a few miles from the Georgian National Defense Academy, one of the Georgian military's intellectual centers.

Georgia is a nation with a proud history. At its height during the early Middle Ages, its territory encompassed a large percentage of the Black Sea's shoreline, and the Georgian Orthodox Church is one of the oldest churches in the world. ${ }^{19}$ Today, there are nearly 5 million people in Georgia who participate in a vibrant democracy with overwhelming aspirations to join the EU and, to a lesser extent, NATO. ${ }^{20}$

Throughout its history, independent Georgia has struggled with a number of ethnically charged conflicts. There are three autonomous regions in Georgia: Adjara, Abkhazia, and South Ossetia. Adjara is home to a popular beach city, 
Batumi, and after a 2004 crisis there in which an authoritarian regional leader was pressured to resign, it has been firmly under Georgian control. ${ }^{21}$ However, there is a long history of ethnic tension, fueled by Russian incitement, especially in the breakaway regions of Abkhazia and South Ossetia. Throughout a series of wars there in the 1990s, it became clear that a special solution was needed for these regions. ${ }^{22}$

The situation in Abkhazia and South Ossetia was never resolved, however, and the path toward war with Russia began with Georgia's Rose Revolution in 2004. In a series of events like those in Ukraine, the 2004 presidential election in Georgia was considered fraudulent to many. The incumbent regime clung to power despite evidence that Mikheil Saakashvili had been victorious. The general populace, exhausted by years of perceived corruption centered around the regime of Eduard Shevardnadze, came to the streets to protest his continued grip on power. Shevardnadze tried to consolidate his hold on the Georgian presidency, but much of the military refused to support him. Out of options, he resigned, and Saakashvhili assumed the presidency. ${ }^{23}$

Saakashvili was decidedly in favor of greater Georgian integration with NATO and the EU, and his party was openly anti-Russian. As his government took a number of steps to increase their cooperation with the EU and participation in NATO's primary conflicts, Russian opposition to Georgia's new political direction crystallized. Soon after Saakashvili assumed the presidency, the Georgian military began a period of heavy cooperation with NATO that continues today. Defense cooperation with Georgia includes both training and operational support, and the Georgian military has fought alongside the United States and its allies in Afghanistan and Iraq since 2003. In fact, of all the countries that have participated in the Afghanistan War, Georgia has suffered the most-it has lost more soldiers killed in action per capita than any other country in the world. ${ }^{24}$ The strong NATO-Georgia relationship was, and continues to be, unacceptable to Russia. ${ }^{25}$ After Georgia started down this path, conflict in Abkhazia and South Ossetia may have been inevitable as Russia sought to assert its dominance over its neighbor and send an unequivocal message- that Georgia did not belong in the EU and NATO.

In the years following Saakashvili's election to the presidency, tensions escalated in Georgia's breakaway regions. Russia and Georgia agreed to establish a joint peacekeeping force under Russian command, but the international community was not invited, and UN and OSCE monitoring efforts were limited. ${ }^{26}$ Russia, meanwhile, began improving its military infrastructure in the region, preparing to quickly shuttle troops and supplies to the Caucasus if necessary. ${ }^{27}$ The situation remained relatively stable, however, until NATO's 2008 summit in Bucharest, Romania.

There, NATO's member states, conflicted on how to approach Ukraine and 
Georgia's applications for membership, decided to defer the decision until later in the year, opting instead to publicly claim that "NATO welcomes Ukraine's and Georgia's Euro-Atlantic aspirations for membership in NATO. We agreed today that these countries will become members of NATO." ${ }^{28}$ This was a shock for Russian President Vladimir Putin, who was preparing to pass the presidency to Prime Minister Dmitry Medvedev. He argued that NATO could provide a direct threat to Russian political sovereignty if it continued to expand eastward. ${ }^{29}$

A couple of weeks later, a Georgian drone was shot down by a Russian fighter jet, and Russia had begun to surreptitiously build up troop concentrations in both Abkhazia and South Ossetia, claiming that the increase was justified by the threat of an impending Georgian attack. ${ }^{30}$ In early August, a Russian military column advanced through the Roki Tunnel, one of the major thoroughfares through the Georgian Caucasus. President Saakashvili, upon receiving the call from his commanders that conventional Russian forces were making a hostile advance into Georgian territory, ordered an artillery strike. After hanging up the phone, he turned to look at his senior advisors and said, "It has started. Do you think we will end up as Israelis or Palestinians?" 1

After the Georgians fired on the Russian convoy, the Russian side began a campaign of maneuver warfare that eventually split the country in half. At the southern limit of the Russian advance, it covered the main highway connecting eastern and western Georgia, as well as the primary oil pipeline between the Caspian and the Black seas. While the Russians split the country in half, the government evacuated Tbilisi and prepared to defend the capital. Despite rumors that the Russian army would take the capital, Putin opted to limit his troops' advance to the Georgian administrative boundaries of South Ossetia, which gave the highway and pipeline back to Georgia. ${ }^{32}$

Following the cessation of hostilities a few days after the Georgian artillery strike, the Russian forces withdrew to the borders of South Ossetia and Abkhazia. Russia's government adopted a measure to recognize the independence of South Ossetia and Abkhazia, and in response President George W. Bush issued a formal denunciation of the move. ${ }^{33}$ However, no sanctions or further international action were taken. In the years following the end of the conflict, the Russian military frequently encroaches farther into Georgian territory. ${ }^{34}$

\section{A Comparison of the Conflicts: Georgia, Ukraine, and the Competition between NATO and Russia}

Georgia and Ukraine share several important characteristics. They stand on a similar geographic footprint — and they both share borders with two competing powers, Russia and NATO. There is a developing sense of shared understanding between Ukraine and Georgia. They have taken a similar path toward modern- 
ization and integration with the Western world, particularly with NATO, and they have consequently been regarded with the same suspicion by the Kremlin. Today, Ukrainians vacation in Georgia's bustling beach getaway, Batumi, and Georgians watch with pride as Ukraine's newly reformed police force-the brainchild of Georgia's former internal minister, Ekaterine Zguladze-wins back the trust of a Ukrainian nation accustomed to corrupt policing practices. ${ }^{35}$

Most significantly, however, Georgia and Ukraine share parts of their borders with both Russia and at least one significant NATO ally-Turkey in Georgia's case, and Poland and Romania for Ukraine-yet neither are currently a member of any security agreement. Without an alliance, countries are vulnerable to the vagaries of larger neighbors, and Georgia and Ukraine are no exception. ${ }^{36}$ Because of this vulnerability, Ukraine and Georgia found themselves in increasingly precarious standing with Russia. Given their stated objectives of Euro-Atlantic integration and Russia's interest to prevent the growth of the pan-Atlantic alliance and the European Union, conflict may have been inevitable.

There are some interesting similarities in Russia's battle plan leading up to conflict in both Ukraine and Georgia. During the peacekeeping phase in South Ossetia and Abkhazia, Russia would issue its passports to any citizen of a breakaway region who could claim to be ethnically Russian. ${ }^{37}$ In this way, when hostilities intensified, the government could claim that it was invading the regions to protect the Russian people living there. A similar strategy is being employed in Ukraine today. ${ }^{38}$

Additionally, Russia's powerful information warfare capability was first put on display during the run-up to hostilities in Georgia. Hackers found vulnerabilities in Georgian government websites, and when the conflict turned hot, they struck. For example, on the home page of the Georgian foreign ministry, the contents were replaced by images of Saakashvili and Adolf Hitler superimposed onto one another. ${ }^{39}$

However, observers have noted that Russia's foreign influence campaigns have evolved considerably since the turn of the millennium. For example, during the 2004 presidential election in Ukraine, masked men came to polling booths to intimidate voters, and voter rolls were significantly and obviously modified to support the pro-Kremlin candidate. In 2014, during another presidential election, in place of masked men and overt voting fraud, pro-Russian hackers infiltrated the computer systems of the voting commission. The hackers installed malware and reported fake results intending to show that an ultranationalist, far-right group had won the presidency in an attempt to discredit the pro-EU factions of Ukraine's government. The breach was only discovered one hour before the official results were announced, but Russian state media continued to report the fake results. ${ }^{40}$ 
The Georgian conflict provides an interesting case study in the development of Russia's foreign influence strategy. Using a combination of physical and informational effects from the development of new military infrastructure to widespread propaganda proliferation, Russia succeeded in convincing many residents of Abkhazia and South Ossetia that Russia was their protector against a rapacious, untrustworthy Georgian government. ${ }^{41}$ The use of crude cybertactics, such as the foreign ministry website hack, demonstrates an early interest in cyber as a domain of political warfare.

Additionally, statements made by Margarita Simonyan, the editor-in-chief of Russia's principal propaganda outlet, RT, confirm that the Georgian conflict was a turning point in the development of Russia's information warfare strategy. Noting the importance of preconflict messaging, in a 2013 interview, she said, "Of course, the Defense Ministry can't start training soldiers, preparing weaponry and generally making itself from scratch when the war already started. If we don't have an audience today, tomorrow and the day after, it'll be the same as in 2008 [in Georgia]." 42 By comparing her news outlet to the military, Simonyan indicates that she believes RT is an arm of Russia's coercive international apparatus, ready to be employed in the service of government objectives. This undermines the credibility of RT and highlights the whole-of-government approach that Russia takes to foreign influence operations.

During the conflict with Russia, pro-Kremlin propaganda focused heavily on claims of Georgian "genocide" against the indigenous population to justify the sudden appearance of more Russian peacekeeping troops. However, in independent investigations conducted after the conclusion of hostilities in 2008, the claims of genocide or ethnic oppression were disproven. ${ }^{43}$ There were acts of criminal significance conducted by the Georgians and their opponents, to be sure, but to claim that Georgian actions in the area amounted to systematic oppression or genocide do not stand up to reality. Despite this, decades of ethnically charged conflict created a ripe atmosphere for Russian manipulation, exposing Georgia to the onset of war in 2008.

There is little indication in Ukraine's history of government-sponsored oppression against the Russian-speaking minority. While there is a significant Russian-speaking population in eastern Ukraine and Crimea, claims from the Russian government that the Ukrainian government had systematically oppressed them are simply false. Under Ukrainian law, a region is permitted to establish its own official language through an open democratic process. ${ }^{44}$ In practice, many Ukrainians use the Russian language daily, and there is little to no animosity between speakers of the different languages. One of Ukraine's most popular television shows, Sluga Naroda, features a Russian-speaking president of Ukraine who wins the hearts of the citizenry through his sweeping efforts to eliminate corruption. Its widespread popularity demonstrates the in- 
significance of language as a point of contention between most Ukrainians.

There was also a large disparity in the degree of international exposure and response to the two conflicts. When the Russian armored column advanced through the Roki Tunnel and the Georgians fired upon them, most Western organizations offered no significant response. ${ }^{45}$ However, when Crimea was illegally annexed and the war kicked off in the Donbass region, Ukraine was suddenly under the international spotlight to a degree not enjoyed by the Georgians. The threat of a disruption in the supply of gas to Western Europe, much of which is delivered from Russia via Ukrainian pipelines, provided an immediate, concrete incentive for governments to become involved. ${ }^{46}$ The shooting down of Malaysia Airlines Flight 17 over Ukraine's conflict zones with Russia also contributed immensely to the West's interest in this conflict as opposed to the Georgian conflict with Russia. ${ }^{47}$

It is important to note that there are critical differences in the Russian perception of both countries. Georgia held a position of prominence during the Soviet Union as the birthplace of its greatest leader, Joseph Stalin, and as a mountain getaway for the governing elite. However, Georgians are Caucasians, not Slavs, and Ukraine holds a very different place in the Russian national memory. Kyiv is the historical home of Kyivan Rus', a state that both Ukrainians and Russians consider to be their historical predecessor, and Ukrainians and Russians are linked by a history of thousands of years. ${ }^{48}$ This legacy has given many Russians a big brother feeling over Ukraine, which has been noted by Western observers: "Driven by perceptions of shared history, religion, and culture, much of the Russian elite is incapable of thinking about Ukraine other than as a suzerain client." ${ }^{49}$

The final major difference is in Western perceptions of the kindling of both conflicts. Saakashvili was regarded by Western powers, most notably Germany, as a hothead who could not be trusted. ${ }^{50}$ This reputation was confirmed in their eyes when he ordered the artillery strike that kicked off hostilities in $2008 .{ }^{51}$ An independent investigation conducted after the conflict concluded that Georgia's president acted rashly and shared responsibility with Russia for the onset of war. ${ }^{52}$ Ukraine has no political leader with a similar reputation. There is little doubt in the eyes of Western observers that the conflict in Ukraine was instigated by powers outside of its boundaries, and it would be difficult to place the blame for the conflict on the shoulders of any pro-Ukrainian politician. The Ukrainian military suffered from desperately low levels of readiness and was largely unprepared for the war. In fact, much of the early fighting was done not by government forces but volunteer battalions composed of armed civilians and funded by Ukrainian oligarchs. ${ }^{53}$ This lack of an organized response is, ironically, one of Ukraine's biggest advantages in its struggle for territorial integrity. It demonstrates that Ukraine is the victim of a Russian plot against its territorial 
integrity, and comments made by Putin in the subsequent years have confirmed this perspective. ${ }^{54}$

\section{The Way Forward}

In Ukraine and Georgia, Russia experienced both strategic gains and setbacks. Although the military equilibrium was shifted in Russia's favor in both instances, neither conflict could extinguish the liberal, pro-European political movements that had been the genesis of Russian grievances from the start. Russia was spurred to action in both Georgia and Ukraine by the establishment of regimes that hoped to increase their countries' integration with Western institutions. As a result of the conflicts, Russia increased its geographical influence and likely assured its ability to project power from the Black Sea region for decades to come. In response, however, NATO has become much more focused on the Russian threat, and both Georgia and Ukraine have continued the path of reform and integration, albeit slowly and imperfectly.

Specifically, in the case of Ukraine, Russia's actions have laid bare the brutality of Russia's intentions. Many were shocked to witness the rapidity with which Russia was able to incite neighbor-on-neighbor violence in the Donbass. This has led to the entrenchment of a severe sense of betrayal among moderate Ukrainians, many of whom accepted an ethnic and historical linkage between the two countries before the conflict. According Wood et al., the conflict has only increased feelings of patriotism and anti-Russian sentiment among Ukrainians: "although only a minority of Ukraine's population was antiRussian before the crisis, Moscow's resort to war has created a genuine sense of nationhood in parts of that country where previously it had been weak." 55

The United States and its allies should take every available step to support legitimate governance in the entire region. The continued high level of support that the United States exhibits for its key allies in the region like Romania, Poland, Latvia, Lithuania, and Estonia must remain a priority. If Russian military activity in Eastern Europe continues to escalate, it will be critical to stand firm with our NATO allies in support of stability in the region. Continuous presence is critical, and United States European Command's (EUCOM) many ongoing security cooperation initiatives, such as Atlantic Resolve, Saber Strike, and Marine Rotational Force-Europe should remain a cornerstone of this strategy.

Additionally, the United States should continue its support of the Ukrainian military. The Ukrainian Ministry of Defence has come under heavy scrutiny for its low level of readiness. While NATO integration is not an immediate objective, the United States should spearhead the effort to develop the Ukrainian military into a modern, responsible security force capable of containing the crisis and standing as a bulwark against further destabilization in Europe.

The Ukrainian conflict is larger, more deadly, and more shocking than the 
war in Georgia. Russia's actions in Ukraine stepped beyond its strategic intent as we knew it at the time. Few observers of Eurasian geopolitics were able to predict the speed and coordination with which Russia would annex Crimea and instigate insurgency in the Donbass. It was a precise and well-executed operation, and its boldness and audacity went beyond most estimates of Russian intention. With Central and Eastern Europe becoming one of the most rapidly militarizing regions on the planet, the future is uncertain and potentially dangerous. ${ }^{56}$

A significant challenge that Western institutions will face as the Ukraine conflict continues is that of strategic patience. Putin was recently reelected, ensuring an approximate continuation of Russian policy for the next six years. Ukraine faces a presidential election in 2019 and the EU suffers a high rate of turnover and political inertia. From the point of view of the ordinary Ukrainian who only desires peace and stability, Russia’s influence may become more appealing as the conflict drags on without resolution. Russia is sure to use the full force of its information capabilities to attempt to sway the Ukrainian populace to its side and discredit the Western narrative. Employing a whole-ofgovernment approach and relying on its strategic patience, Russia will likely benefit from conflict fatigue in Ukraine.

Many authors have claimed that the West's unwillingness to unambiguously sanction Moscow for the Georgian war may have emboldened the Kremlin to extend its destabilization operations to Ukraine. ${ }^{57}$ In truth, the United States and its allies offered no concrete challenge to Russia's actions in Georgia. Saakashvili's reputation as a demagogue led many Western governments to come to his aid only slowly, and many policy makers believed that a reset in relations with Russia was more important than punishment. However, the experience in Ukraine has demonstrated the opposite. Considering the failure of deterrence following the Georgian war, NATO and its allies should be ready to quickly update force posture if hostilities were to arise in another buffer state such as Moldova.

One of the main lessons of both Georgia and Ukraine is that Russia can rapidly degrade the security situation before we can react. In both conflicts, Russia had achieved most of its tactical objectives before many Western governments could come to a consensus on what was happening on the ground. Slow response is unacceptable in irregular warfare, and the synchronization of efforts both within and across national governments is a critical step toward achieving an appropriate response framework.

Ultimately, the conflict in Ukraine will likely persist until there is regime change in Moscow or Kyiv. However, the United States and its allies should continue to display a unified front and promote stability in Europe as a whole. NATO's nuclear and conventional deterrent has so far been successful in containing Russian military activity to buffer states. Despite this, Putin and his 
security apparatus will take advantage of any perceived weakness in the U.S.-led status quo. If the United States and its European allies desire a peaceful future for Europe, it must be enforced through a strong stance at its eastern doorstep, expressed through both diplomatic and military means.

\section{Conclusion}

In closing, it is critical to note that the war of ideas provides the first line of defense. In an increasingly connected world, the battlefield can be shaped through information operations well before a conflict goes kinetic. As we prepare for a more uncertain future, we must continue to emphasize democratic values and international integration in the region. According to Secretary of Defense Mattis,

Putin seeks to shatter NATO. He aims to diminish the appeal of the Western democratic model and attempts to undermine America's moral authority. His actions are designed not to challenge our arms, at this point, but to undercut and compromise our belief in our ideals. ${ }^{58}$

The secretary of defense is right; our center of gravity is not a weapons system, a formation of troops, or a command and control network, but our belief in the defining principles of our democracy, such as freedom of expression, respect for the law, and support for the development of democratic ideals. As the key terrain of the ongoing great power competition, this belief should continue to serve as the defining characteristic of our security policy in Eastern Europe and throughout the world.

\section{Notes}

1. Ukraine's capital has two different spellings: Kyiv and Kiev. Kyiv is the official Ukranian transliteration of the name and is used most frequently within Ukraine, while Kiev is an outdated Russian transliteration from Soviet times.

2. Report on the Human Rights Situation in Ukraine 16 August to 15 November 2017 (Geneva, Switzerland: Office of the United Nations High Commissioner for Human Rights, 2017); and Pavel Polityuk and Anton Zverev, "Why Ukrainian Forces Gave up Crimea Without a Fight—and NATO Is Alert," Reuters, 24 July 2017.

3. "Russia’s Top Five Myths about NATO," North Atlantic Treaty Organization, July 2018.

4. Secretary of Defense James N. Mattis, "Remarks by Secretary Mattis at the U.S. Naval War College Commencement, Newport, Rhode Island," Department of Defense, 15 June 2018.

5. Steven Erlanger, “The World; Learning to Fear Putin's Gaze," New York Times, 25 February 2001. The term near abroad encompasses the former countries of the Soviet Union.

6. Serhii Plokhy, The Gates of Europe: A History of Ukraine (New York: Basic Books, 2017), 41.

7. Plokhy, The Gates of Europe, 103.

8. A Bolshevik is member of a wing of the Russian Social-Democratic Workers' Party, which, led by Vladimir Lenin, seized control of the government in Russia (October 
1917) and became the dominant political power; a Menshevik is a member of the non-Leninist wing of the Russian Social-Democratic Workers' Party, which evolved into a separate organization.

9. Plokhy, The Gates of Europe, 219.

10. LtCol Donald Thieme, USMC, "A Brief History of Conflict in Ukraine," USNI News, 11 March 2014.

11. Plokhy, The Gates of Europe, 315.

12. J. Gordon Hylton, "Understanding the Constitutional Situation in Crimea," Marquette University Law School Faculty Blog (blog), 16 March 2014.

13. Plokhy, The Gates of Europe, 333.

14. "Ukraine Crisis: Timeline," BBC News, 13 November 2014.

15. Johan Norberg, "The Use of Russia's Military in the Crimean Crisis," Carnegie Endowment for International Peace, 13 March 2014; and Julia Summers, "Countering Disinformation: Russia’s Infowar in Ukraine," Henry M. Jackson School of International Studies-University of Washington, 25 October 2017.

16. Cory Welt, Ukraine: Background and U.S. Policy (Washington, DC: Congressional Research Service, 2017); Shaun Walker, "When a Reporter Crossed the Kremlin's Borderline," Coda Story, 6 March 2018; and Valeriy Shiryaev, "'Polite People' in Crimea: How It All Happened," Novaya Gazeta, trans. Michael Auten, 17 April 2014.

17. "Russia Is Negotiating with Germany and France over Ukraine," Economist, 22 October 2016.

18. Report on the Human Rights Situation in Ukraine 16 August to 15 November 2017.

19. "Georgian Orthodox Church," Encyclopaedia Britannica, 22 January 2015.

20. "Middle East: Georgia," CIA World Factbook, 13 November 2018; and Diana Chachua, "NDI Poll: Georgians Increasingly Support EU and Euro-Atlantic Aspirations; View Russia as a Threat," National Democratic Institute, 12 May 2017.

21. Jean-Christophe Peuch, "Georgia: Having Secured Adjara, Tbilisi Turns to Abkhazia with an Eye on Russia," Radio Free Europe/Radio Liberty, 19 May 2004.

22. Ronald D. Asmus, A Little War that Shook the World: Georgia, Russia, and the Future of the West (New York: Palgrave Macmillan, 2010), 59.

23. Maurice Weeks, "Georgians Overthrow a Dictator (Rose Revolution), 2003," Global Nonviolent Action Database, 20 October 2008.

24. Luke Coffey, NATO Membership for Georgia: In U.S. and European Interest (Washington, DC: Heritage Foundation, 2018), 1.

25. David J. Kramer, "Renewed Confrontation in Georgia," Council on Foreign Relations, 17 March 2016.

26. "OSCE 'Failed' in Georgia Warnings," BBC News, 8 November 2008.

27. Asmus, A Little War that Shook the World, 150.

28. "Bucharest Summit Declaration: Issued by the Heads of State and Government Participating in the Meeting of the North Atlantic Council in Bucharest on 3 April 2008," press release, NATO, 3 April 2008.

29. Adrian Blomfield and James Kirkup, "Stay Away, Vladimir Putin Tells NATO," Telegraph, 5 April 2008.

30. Asmus, $A$ Little War that Shook the World, 147.

31. Asmus, A Little War that Shook the World, 36.

32. “2008 Georgia Russia Conflict Fast Facts," CNN, 21 March 2018; and Asmus, A Little War that Shook the World, 187.

33. Aleksey Nikolsky, "Recognition of the Independence of Abkhazia and South Ossetia," RIA Novosti, trans. Michael Auten, 26 August 2012; and President George W. Bush, "George W. Bush Statement on Russian/Georgian Conflict," YouTube, 2:45, $11 \mathrm{Au}-$ gust 2008.

34. Andrew Higgins, "In Russias 'Frozen Zone,' a Creeping Border with Georgia," New York Times, 23 October 2016.

35. Tunku Varadarajan, "Talent from Tbilisi: A Young Georgian Technocrat Tries to Clean up Ukraine's Police," Politico, 3 September 2015.

36. Kostiantyn Fedorenko and Andreas Umland, "How to Solve Ukraine's Security Dilem- 
ma?: The Idea of an Intermarium Coalition in East-Central Europe," War on the Rocks (blog), 30 August 2017.

37. Independent International Fact-Finding Mission on the Conflict in Georgia Report (Brussels: Council of the European Union, 2009), 18.

38. "Moscow to Start Distributing Russian Passports in the Occupied Donbas [sic]," Euromaidan Press, 21 February 2017.

39. Asher Moses, "Georgian Websites Forced Offline in 'Cyber War'," Sydney (Australia) Morning Herald, 12 August 2008.

40. Alina Polyakova and Spencer Phipps Boyer, The Future of Political Warfare: Russia, the West, and the Coming Age of Global Digital Competition (Washington, DC: Brookings Institution, 2018).

41. Gerard Toal and John O'Loughlin, "How People in South Ossetia, Abkhazia and Transnistria Feel about Annexation by Russia," Washington Post, 20 March 2014.

42. Ben Nimmo and Aric Toler, "The Russians Who Exposed Russia's Trolls: A Tribute to the Russian Journalists Who Exposed the 'Troll Factory'," Medium, 8 March 2018.

43. Independent International Fact-Finding Mission on the Conflict in Georgia Report, 17.

44. Constitution of Ukraine, chapter 1, article 10.

45. Asmus, A Little War that Shook the World, 145.

46. Simon Pirani and Katja Yafimava, Russian Gas Transit across Ukraine Post-2019: Pipeline Scenarios, Gas Flow Consequences, and Regulatory Constraints (Oxford: Oxford Institute for Energy Studies, 2016).

47. "MH17 Ukraine Plane Crash: What We Know," BBC News, 28 September 2016.

48. Zenon E. Kohut and David M. Goldfrank, "Historical Setting: Early History to 1917," in Russia: A Country Study, ed. Glenn E. Curtis (Washington, DC: Department of the Army, 1998).

49. Elizabeth A. Wood et al., Roots of Russia's War in Ukraine (New York: Columbia University Press, 2016), 37-38.

50. Ralf Beste, Markus Feldenkirchen, and Alexander Szandar, "Germany and the Caucasus Conflict: Merkel's Most Serious Foreign Policy Crisis," Spiegel Online, 18 August 2008.

51. "Did Saakashvili Lie?: The West Begins to Doubt Georgian Leader," Spiegel Online, 15 September 2008.

52. Independent International Fact-Finding Mission on the Conflict in Georgia Report, 22.

53. Rosaria Puglisi, Heroes or Villains?: Volunteer Battalions in Post-Maidan Ukraine (Rome: Istituto Affari Internazionali, 2015).

54. Neil MacFarquhar, "Putin Contradicts Claims on Annexation of Crimea," New York Times, 9 March 2015.

55. Wood et al., Roots of Russia's War in Ukraine, 43.

56. Nolan Peterson, "The 2 Largest Land Armies in Europe Tiptoe to the Edge of War and Back," Daily Signal, 9 December 2016; and Eastern Europe Regional Security System: Place and Engagement of Ukraine (Sankt Augustin, Germany: Konrad Adenaur Siftung, 2017).

57. Vasil Jaiani, "6 Unintended Consequences from the West's Passive Response to the Ukraine Invasion,” Forbes, 5 March 2014.

58. Mattis, "Remarks by Secretary Mattis at the U.S. Naval War College Commencement, Newport, Rhode Island." 


\title{
Superpower Hybrid Warfare in Syria
}

\author{
Anthony N. Celso, PhD
}

\begin{abstract}
This article examines superpower hybrid warfare in four parts. First, it provides an overview of hybrid warfare and its tactical, if controversial, uses. Second, it analyzes Russia's hybrid warfare in Ukraine. Third, it compares U.S. and Russian hybrid techniques in Syria. Finally, it assesses the conditions under which Syria could be a flashpoint for superpower conflict. The essay argues that American and Russian policy in Syria represents a unique case where military interventions attained objectives at a relatively low cost because determined local partners facilitated the realization of superpower goals.
\end{abstract}

Keywords: hybrid warfare, superpower competition, Syria civil war, gray zone conflicts, war on terrorism

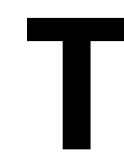

his article analyzes hybrid warfare by major powers in Syria. Though bybrid warfare interpretations vary, they sketch a military-political strategy that mixes conventional and irregular warfare techniques. ${ }^{1}$ Recently, this new way of war has proven effective for the United States and Russia in Syria. Superpower success, however, reflects unique circumstances. American and Russian policy in Syria represents a rare case where military interventions attained objectives at a relatively low cost. Capable local partners facilitated the realization of superpower goals because their interests converged with those of their patron.

Washington's policy to degrade and dismantle the Islamic State's (IS) caliphate and Moscow's equally ambitious strategy to secure the survival of President

Dr. Anthony N. Celso is a professor of security studies at Angelo State University in San Angelo, TX. He is the author of Al-Qaeda's Post-9/11 Devolution: The Failed Jihadist War against the Near and Far Enemy (2014) and the The Islamic State: A Comparative History of Jihadist Warfare (2018).

MCU Journal vol. 9, no. 2

www.usmcu.edu/mcupress 
Bashar al-Assad's regime were obtained. Antigovernment rebels and IS's forces were seriously weakened. Superpower intervention in Syria contrasts with the problematic record of America's large conventional deployments in Iraq and Afghanistan and Russia's disastrous wars in Afghanistan and Chechnya. ${ }^{2}$

America's Special Forces, local allies, and targeted air power from 2014 to 2018 helped destroy IS's state building. Proxy Kurdish forces and their Arab allies played a critical role in U.S. combat operations against the caliphate. Combined with American directed air strikes against IS's positions, local auxiliaries drove the caliphate's soldiers from most of northeastern Syria. IS lost much of its Syrian territory to the Syrian Democratic Forces (SDF), whose military backbone is the Kurdish Popular Defense Units—-known by its Kurdish name, Yekîneyên Parastina Gel (YPG). ${ }^{3}$ Greatly aiding the U.S. mission were determined local allies willing to bear the cost of fighting a fanatical enemy. Kurdish forces in 2017 alone lost almost 1,000 fighters. ${ }^{4}$

Moscow's use of Hezbollah, the Islamic Revolutionary Guard Corps (IRGC), Russian mercenaries, and Shia militias and its own brutal air war against anti-Assad rebels secured Damascus and Aleppo, turning the tide of the war. ${ }^{5}$ The martyrdom culture of Shia groups fighting in Syria assisted the ground campaign and allowed Russian forces to avoid most of the hard fighting. Having secured Syria's two major cities, Assad and his allies drove IS forces from the Roman-era ruins of Palmyra and some of the Deir ez-Zor region. Without Russian airpower, Iranian assistance, and Shia militiamen, Assad's regime would have succumbed to rebel forces. By 2015, Damascus was experiencing severe manpower shortages and rebels were advancing on Damascus, Aleppo, and Latakia. ${ }^{6}$ Faced with a weakened strategic ally, Moscow intervened militarily in September 2015. Russia and Iran's support played a pivotal role in stemming rebel advances and forcing secular and jihadi forces back to Idlib province where they face bombing and ground assaults. ${ }^{7}$

Though American and Russian hybrid strategy had different goals, they relied on similar methods. Since 2015, Washington and Moscow's military approach upended irregular forces whose asymmetrical guerrilla strategy failed to effectively counter massive airstrikes and determined ground forces. Russia's targeting of rebel civilian supporters and its destruction of the infrastructure necessary to sustain life in insurgent areas prevented jihadist forces from effectively using human shields.

Faced with a bombing campaign that made existence untenable in oppositionheld towns, rebels capitulated. Moscow's bombing of hospitals, water facilities, and food-distribution sites was designed to force the population to submit and undermine guerrilla support. It worked spectacularly well. The effectiveness of Russia's intervention raises serious questions about the utility of a hearts-andminds strategy popular among counterinsurgency theorists. ${ }^{8}$ 
The success Washington and Moscow attained could presage future destabilizing conflict. Aside from combating jihadist forces, Russia and America's goals in Syria diverge. 'The Kremlin's support for Iran, Hezbollah, and Shia militias' expanded presence in Syria undermines U.S. interests. Tehran's intent to establish a land bridge funneling weapons and supplies to IRGC forces across Iraq to Syria imperils U.S. forces and the SDF. ${ }^{10}$

Iran's projection of aligned military force toward the Golan Heights, moreover, endangers Israeli security. Jerusalem has responded. Since 2014, Israel has attacked Hezbollah interests in Syria more than 150 times. ${ }^{11}$ Tehran's missile and drone production facilities in Syria also have been targeted by Israel. Israel's downing of an Iranian drone that penetrated its airspace and its bombing of IRGC bases in Syria have invited tit for tat retaliation.

In May 2018, IRGC units fired 20 missiles at Israeli army positions in the Golan Heights, impelling Jerusalem to respond with sustained air strikes designed to cripple Tehran's military infrastructure across Syria. ${ }^{12}$ Today, observers speak of a coming war between Israel and Iran. ${ }^{13}$

Underscoring Syria's complexity as an arena for conflict are many external actors with contending interests. Turkish, Russian, Iranian, and American forces in Syria support different parties in a multisided civil war where divergent interests have resulted in repeated clashes. U.S. military strikes in July 2017 and February 2018 killed hundreds of Russian mercenaries, IRGC soldiers, and Hezbollah soldiers, and that breached negotiated territorial demarcations separating combatants. ${ }^{14}$

De-escalation agreements made by the Americans, Russians, Iranians, and Turks are inherently ambiguous and transitory. ${ }^{15}$ Conflict is inevitable. Ankara's military campaign to drive Kurdish YPG forces from Syria's northwest border threatens U.S. soldiers. Finalizing future rules of engagement that avoid military conflict between regional and international powers in Syria will be challenging.

This article examines the concept of superpower hybrid warfare in four parts. First, it provides an overview of hybrid warfare and its tactical if controversial uses. Second, it analyses Russia's hybrid warfare in the Ukraine. Third, it compares U.S. and Russian hybrid techniques in Syria. Finally, it assesses the conditions under which Syria could be a flashpoint for superpower conflict.

\section{Hybrid Warfare}

Though the concept's origins are contested, Frank G. Hoffman in 2007 coined the modern usage of the term hybrid warfare. ${ }^{16} \mathrm{He}$ did so after analyzing Hezbollah's 2006 war with Israel in Lebanon. Largely viewed as Tehran's proxy force, Hezbollah's media propaganda campaign, use of underground tunnels, guerrilla tactics, and deployment of Iranian-built missiles succeeded in fighting a technologically superior Israeli force to a standstill. During that conflict, Hez- 
bollah synchronized its military and communication strategy to highlight its own battlefield achievements and the setbacks of its enemy.

Jerusalem's inability to inflict a devastating defeat on Hezbollah was widely celebrated throughout the Arab world. Israel's use of mass bombing was, moreover, condemned by global media outlets for the civilian casualties it caused and for its destruction of Lebanon's infrastructure. Israel's 2006 war with Hezbollah proved an embarrassing public-relations disaster and tactical military blunder. ${ }^{17}$

Assessing the group's strategy, Hoffman writes, "hybrid threats incorporate a full range of different modes of warfare including conventional capabilities, irregular tactics, terrorist acts, including indiscriminate violence and coercion, and criminal disorder." ${ }^{18}$ These techniques, moreover, can be employed by state and nonstate actors. Given Hezbollah's successful strategy against Israel's conventional forces, state mastery of hybrid warfare is critical.

Rand analyst Andrew Radin defines hybrid warfare as "covert or deniable activities, supported by conventional or nuclear forces, to influence the domestic politics of target countries." 19 Examining Russia's use of hybrid warfare in Ukraine, Radin sees Moscow employing a combination of tactics whereby conventional forces support and defend irregular forces. ${ }^{20} \mathrm{Vital}$ to the success of any hybrid warfare campaign is an information strategy designed to deny the perpetrator's direct military involvement. Russia, for example, has consistently denied the existence of its armed forces in Ukraine despite compelling contradictory evidence. ${ }^{21}$ Scholar Emilio Iasiello views Russian actions in Ukraine as effectively "leveraging the information space to bolster its propaganda, messaging, and disinformation capabilities in support of geo-political objectives." 22

Dmitri Trenin argues that Russia and America are waging a hybrid war globally as Moscow seeks to resurrect its historic position as a great power by undermining American geopolitical interests across the globe. ${ }^{23}$ In this war, each antagonist uses information, economic, political, and military means to promote their own national security objectives and constrict their rival's strategic interests. Hybrid warfare strategy combines a range of cyber, propaganda, irregular, and conventional weapons to facilitate national security goals short of full-scale war. It represents a range of limited warfare techniques designed to coerce and intimidate opponents and manipulate domestic and international audiences. This type of combat has a past legacy. Athenian and Roman military strategies frequently employed mercenaries and other auxiliaries to complement their conventional forces. Such forms of warfare persisted well into the nineteenth century. Robert D. Kaplan's book Imperial Grunts speaks of how the U.S. Army used to excel at asymmetric warfare against North American indigenous tribes. $^{24}$

The American military campaign to quash the Moro insurgency in the Philippines also involved hybrid warfare against an irregular enemy. The Army's 
use of targeted killing, its mass expulsion of civilian populations, and use of indigenous auxiliaries weakened the insurgency. It was, furthermore, the first encounter fighting Islamist guerrillas the U.S. Army experienced. Kaplan argues that today's military planners should study the success America achieved in that campaign.

Other examples of effective state-directed irregular warfare abound. Though referred to as the "graveyard of empires," Britain's second foray into Afghanistan (1878-80) relied on its own forces and Indian auxiliaries to defeat the Islamic Emirate of Afghanistan, allowing the deposed Sher Ali Khan's successors autonomy, provided that their foreign policy advanced London's strategic interests. ${ }^{25}$

Such state-directed hybrid warfare, however, became less common with the professionalization of militaries. Most twentieth-century adversaries were conventional states making hybrid techniques less necessary. Though the British did use irregular Arab forces to fight the Ottoman Turks in World War I, the use of such auxiliaries was more the exception than the rule. ${ }^{26}$ Combat between standing armies in two world wars and the strategic use of mass bombing created a distinct military culture that viewed conflict mostly from a conventional prism.

The spread of nuclear weapons after World War II and the Cold War period, however, reinvigorated hybrid warfare strategies and the use of proxy forces by international powers. Given the nonutility of a war between the United States and the Soviet Union, they fought each other indirectly through patron states and insurgent groups. Throughout the Cold War, the major powers supported insurgencies designed to weaken their main adversary. Regional powers such as Pakistan, Saudi Arabia, and Iran followed suit. Though Russia achieved success in their support for the Viet Cong fighting U.S. soldiers in Southeast Asia, and America effectively supported Afghan rebels resisting Soviet occupation of Afghanistan, Iran pioneered a modernized version of hybrid warfare. ${ }^{27}$ It remains the prototype for other states.

Tehran's irregular military tactics against U.S. and Israeli interests has been widely studied. ${ }^{28}$ Its terror attacks against Western and Israeli forces in Lebanon were especially devastating. As a pioneer in asymmetric warfare, Iran's military involvement in Syria has married its use of proxy forces with its own conventional military power. This is evidence of the evolutionary character of hybrid warfare. Iran's mastery of hybrid techniques has matured into a full range of coercive capabilities. It was, however, not an easy task.

The overthrow of the U.S.-supported Reza Shah Pahlavi's government in 1979 by Shia Islamist revolutionaries produced shockwaves across the globe. Decrying the United States as the "Great Satan" and committing itself to the destruction of Israel, Tehran's revolutionary regime sought to reorder geomilitary power across the Middle East. Since the revolution, it has relentlessly pur- 
sued this strategy. Iran's ambitions, however, go beyond attacking Western and Jewish interests. Tehran's promotion of sectarian movements across the Middle East, moreover, threatens Sunni states who fear Shia rebellions against their rule. $^{29}$ With significant Shia minorities in Syria, Lebanon, Yemen, and Gulf Arab states and majorities in Iraq and Bahrain, Tehran's sectarian policy raises significant anxiety across the region.

Saddam Hussein's Iraq in 1980 hoped to contain Tehran by exploiting its post-revolutionary vulnerabilities. With a weakened economy exacerbated by a violent political transition, the new regime tenuously clung to power. The revolutionary regime's internal weakness and threatening posture toward its neighbors incentivized Iraq to annex Iranian territory. Hussein's regime, however, underestimated Tehran's resilience, for the Islamic Republic of Iran sent thousands of religiously motivated warriors unafraid of death against its forces. An estimated 1 million people died during the eight-year conflict. ${ }^{30}$ The war devastated both sides, with no clear winner.

Faced with a costly war against Iraqi forces, Iran spearheaded an alternative military strategy using nonstate actors to advance its interests. ${ }^{31}$ The IRGC was tasked with projecting a Shia arc of influence across the Middle East by empowering regional militias. Seen by Tehran as an expeditionary force, the IRGC has trained and armed Shia guerrilla forces in Lebanon, Bahrain, Yemen, and Iraq.

The IRGC's development of Lebanese Hezbollah in the 1980s created a model applied elsewhere. Hezbollah's formation was a consequence of the 1982 Israeli invasion of Lebanon. The Israeli state's military operation was designed to destroy the Palestine Liberation Organization's (PLO) Lebanese military and logistical infrastructure that had launched crossborder attacks.

Israel's policy to disrupt the PLO's presence in Lebanon provided a strategic opening for Iran to support Shia militias resisting Israeli occupation. Recognizing the opportunity to indirectly strike Israeli forces, the IRGC consolidated militias into an insurgent-terror force. Organizing an effective resistance network was impelled by Israel's success in driving the PLO's forces into Beirut. Subsequent developments proved even more fortuitous. Under a United Nations-brokered agreement, international peacekeepers supervised the PLO's evacuation to Tunis.

American and French forces who secured the evacuation plan provided Tehran an opportunity to kill Westerners. Shia martyrs launched devastating suicide bombing attacks across Beirut in 1983, hitting the American embassy, a U.S. Marine barracks, and a French garrison, in which hundreds died. ${ }^{32}$ Withdraw of international forces from Lebanon was seen by Iran as a victory.

Hezbollah's military capabilities matured during Jerusalem's 18-year Lebanese occupation. More than 1,000 Israeli military personnel died in the group's ambushes and suicide bomb attacks. ${ }^{33}$ Israel's withdraw from southern Lebanon 
in 2000 allowed Hezbollah to create a network of underground tunnels and accumulate an immense arsenal of Iranian-supplied short- and medium-range rockets.

Central to Hezbollah's development was Tehran's ability to run its weapons through Syria whose Alawite-dominated government and refusal to sign a peace accord with Israel made Damascus a sectarian and strategic partner. Iranian and Syrian support allowed Hezbollah and Palestinian Hamas to launch attacks in 2006 against Israel's troops. The resulting war proved to be a publicity boon for Hezbollah and its Iranian patron. The Shia militia's capacity to survive a monthlong struggle with Israeli forces contrasted strikingly with past Arab military defeats against the Israeli state.

Fearing a protracted land war with a determined enemy and heavy casualties, Israeli prime minister Ehud Olmert hoped to bomb Lebanon into submission, convinced that Beirut would exert pressure on Hezbollah to relent. The damage done to Lebanon's civilian population and international efforts to end the conflict did not permit Jerusalem sufficient time to follow through with its war aims. This outcome was punctuated by widely publicized images of a burning Israeli frigate hit by a Hezbollah rockets in July 2006, which left indelible impressions of the war. Though Hezbollah took heavy losses and did not win, it survived, earning the admiration of the Arab world. ${ }^{34}$

Since the 2006 war, Iran has strengthened Hezbollah. Tehran has supplied tens of thousands of rockets capable of reaching major Israeli cities. ${ }^{35}$ With its IRGC training, Hezbollah has also developed conventional capabilities to complement its guerrilla tactics. As Tehran's hybrid war strategy evolves, it has deployed its Lebanese auxiliary force in Syria to advance its strategic interests. Despite its reputation as a guerrilla army, Hezbollah has operated largely as a conventional force in Syria.

Deployed in 2013, Hezbollah coordinated its operations with Assad's regime and with Russia's forces in Syria. ${ }^{36}$ Though the Shia militia's military operations in Lebanon are controversial and costly, the group has deployed 6,000-8,000 fighters as an expeditionary offensive force. ${ }^{37}$ Hezbollah leader Hassan Nasrallah justifies the network's Syrian intervention by arguing it secures Lebanon's security.

Without Hezbollah's intervention, the Assad regime may have succumbed to rebels, who early in the conflict made substantial advances. Hezbollah's commitment, coupled with Iran and Russia's support, is credited with turning the tide in Syria’s civil war. ${ }^{38}$ By May 2018, Damascus was advancing on remaining rebel positions in Idlib Province and beleaguered opposition groups in Damascus's Eastern Ghouta region. Augmented by the IRGC's recruitment of thousands of Shia militiamen from Iraq, Afghanistan, and Pakistan, Hezbollah provided the ground force, strengthening Damascus's military position. ${ }^{39}$ Based 
on its Syrian experience, Tehran is developing a multinational expeditionary militia that can be deployed across the region. With violent sectarian conflicts raging across the Muslim world, opportunities to mobilize and dispatch such a force abound.

Syria's complex, multisided war that mixes conventional and irregular forces exemplifies a gray zone conflict. Army Lieutenant General James M. Dubik and Nic Vincent see these conflicts escalating. ${ }^{40}$ They define a gray zone conflict as "hostile or adversarial interactions among competing actors below the threshold of conventional war but above the threshold of peaceful competition." ${ }^{41}$ Gray zone conflicts in weak and failing states compromise the security interests of major powers, forcing their intervention. Such struggles, however, are not amenable to conventional military solutions. Major power disengagement from gray zone areas can be problematic. The U.S. departure from Iraq is seen as contributing to the rise of IS, forcing the American military back into Iraq and later forcing it to extend military operations into Syria.

Gray zone conflicts require complex strategies. Relying on a counterinsurgency strategy to quell a Sunni rebellion in Iraq proved challenging until America was able to coax Sunni tribes away from al-Qaeda in Iraq (AQI). Local proxies (the Anbar Awakening movement) and American Special Forces operations against AQI badly degraded the network and was an initial, if transitory, experience in applying hybrid warfare strategy to fight modern irregular forces. ${ }^{42}$

This copied the success that the United States had in using Central Intelligence Agency (CIA) paramilitaries, Special Forces, and Afghan Northern Alliance by way of Tajik and Uzbek proxies to overthrow the Taliban-alQaeda terror state after the 11 September 2001 (9/11) attacks. ${ }^{43}$ Though widely praised, the model had until now little staying power. As the United States moves from a counterinsurgency model to a counterterror approach, American use of proxy forces is likely to grow and it is not alone in effectively using proxy forces. The Russians, however, have spearheaded hybrid strategies in Ukraine.

\section{Russian Hybrid Warfare in Ukraine}

Used by Western experts, hybrid warfare is controversial when applied to Russian policy in Ukraine. Studies criticize its use because Russia has used conventional forces in its Ukranian intervention. ${ }^{44}$ Russian literature, moreover, does not mention hybrid warfare and only recognizes the concept's relevance in terms of Western perceptions. ${ }^{45}$ Furthermore, regional analysts argue that Russia's Ukraine policy can be traced to the Communist era. Despite the controversy, Russian policy in Ukraine employs hybrid-warfare features.

General Valery Gerasimov, for example, is credited by Western experts with developing the Kremlin's hybrid-warfare strategy. ${ }^{46}$ General Gerasimov's writings, however, do not use the term within a doctrine that mixes irregular and 
conventional warfare techniques. He sketches a strategy that integrates coercive and noncoercive means, falling short of direct military confrontation when dealing with adversaries.

Gerasimov's doctrine also prioritizes information warfare to control the political narrative associated with Russian military policy. Since the Soviet era, Moscow has used reflexive control to condition adversary behavior to reinforce fear of confronting Moscow's actions. ${ }^{47}$ Russian denial of direct military involvement in Ukraine is accordingly an effort to convince NATO to not provide military assistance to the Ukrainian government fighting Russian separatists. Moscow's propagandists assert that such a provocative action by NATO means war with Russia.

Russian disinformation has influenced Western perceptions of its actions in Ukraine. American and European strategists have, for example, overlooked the Kremlin's use of conventional military forces. By some estimates, Moscow deployed 6,000 troops in the country, which are augmented by mercenaries and paramilitaries. ${ }^{48}$ Its army then annexed Crimea. ${ }^{49}$

Russia's Ukrainian problem started with the weakening of the Ukrainian pro-Russian president, Viktor F. Yanukovych, and the strengthening of his Euromaidan parliamentary rivals. ${ }^{50}$ By February 2014, Yanukovych had fled to Russia, resulting in a new government antagonistic to Moscow. Kiev's proEuropean Union (EU) and NATO sentiments threatened the Kremlin's historic sphere of influence in Ukraine. Soon after, Moscow promulgated a Novorossiya (or New Russia) project to liberate and unite Russian minorities across the Baltics and Central Europe. ${ }^{51}$ This initiative was the justification to mount covert military operations in Ukraine.

Russia's presentation of the rebellion as a fight against Ukrainian persecution of Russian-speaking minorities is belied by Moscow's incubation and export of mercenary forces to the country's eastern provinces. Very few Russian Ukrainians are fighting in the Luhansk and Donetsk oblasts. ${ }^{52}$ Disinformation techniques also masquerade Russia's use of conventional forces in breakaway provinces that have augmented its eastern rebels.

The Kremlin's Ukrainian policy employs conventional and irregular forces supported by a denial and disinformation media campaign. Moscow's media strategy, which fraudulently describes Ukraine's eastern revolt as an indigenous phenomenon, is pitched to international and domestic audiences. ${ }^{53}$ It is designed to counter Western retaliation and stoke nationalistic sentiments at home.

By summer 2014, Russian forces launched military operations. The Kremlin's policy had three objectives. ${ }^{54}$ Moscow first envisioned annexing Crimea. Hoping to gain permanent access to warm-water ports and use the territory as a springboard for future incursions, Moscow had secured Crimea by August 
2014. Justifying its annexation of Crimea, the Kremlin organized a referendum where the region's Russian-speaking majority voted for union in the Russian Federation.

Second, the Kremlin manufactured a separatist rebellion in the Donbass and Luhansk provinces, hoping to create a contiguous area to maximize its influence. Armed and financially supported by Moscow-sponsored Russian mercenaries, they were unable to dislodge Ukrainian forces from most of the contested provinces. Hoping to strengthen its position in September 2014, the Kremlin launched a clandestine military incursion into eastern Ukraine that mixed Russian troops with irregular forces. The Kremlin's 6,000 little green men made more robust advances against the Ukrainian army. ${ }^{55}$

Their existence is denied by Moscow, which has labeled such accusations as Western and Ukrainian lies. Despite some territorial gains, Moscow's hybrid army failed to link rail lines between Donbass and Luhansk provinces. The absence of a contiguous area of control weakened Moscow's hoped for third objective of overthrowing the new Ukrainian government.

Undaunted, Putin settled for preserving the Donbass and Luhansk People's Republics as a means for future destabilization. The Kremlin was, however, successful in derailing Ukraine's EU and NATO memberships and preserving its arc of influence. Though the Europeans imposed economic sanctions on Putin's regime, it failed to deter Putin or arm the Ukrainian government.

Russian violations of the 2014-15 Minsk ceasefire accords, moreover, have not spurred the European community and NATO into taking more aggressive actions against Moscow. Fearing being drawn into a land war over Putin's destabilizing policy, NATO has not effectively countered Russia's policy. With Russian-speaking minorities across Baltic Republics, Ukraine is a disturbing precedent. Further aggravating regional fears, Moscow has positioned its troops along the Russo-Ukraine border. Their presence is threatening, and some analysts envision a Russian invasion. ${ }^{56}$ Based on its Ukraine hybrid warfare prototype, the Kremlin has experienced its greatest success in the Middle East.

\section{Superpower Hybrid Warfare in Syria}

Since 2011, the Syrian civil war has produced carnage and human suffering. With more than 350,000 dead and more than 11 million refugees, the conflict has spurred regional and international power intervention. ${ }^{57}$ Russia, Turkey, Western powers (the United States, France, and the United Kingdom), and Iran have troops supporting different actors and their proxy forces. All are involved in a brutal, multisided struggle. The roots of the civil war are equally complicated.

The 2010-11 Arab Spring movement resulted in the downfall of governments in Tunisia, Yemen, and Egypt. The Arab Spring's political reverberations 
were felt across the Middle East and North Africa. Libya degenerated into a civil war, triggering a NATO intervention and toppling Muammar Gaddafi's dictatorial regime. Libya's post-Gaddafi transition has featured continued civil war between three competing governments.

Despite the Arab Spring's upheaval, analysts predicted that Bashar alAssad's regime would withstand mass protests. ${ }^{58}$ Assad's repression, in effect, could surmount any popular resistance. Such assessments proved optimistic, underestimating the ethnosectarian fissures that have always threatened its existence. Syria's colonial-era borders created a multisectarian and ethnic society where Kurds, Arabs, Alawi, Shia, Druze, and Christians coexisted uneasily.

France's patronage of Christian, Alawite, and Druze minorities, furthermore, disempowered the Sunni Muslim majority, breeding sectarian resentment. Postcolonial developments exacerbated these confessional antagonisms. In power since 1970, the Alawite-dominated Assad dynasty reinforced these sectarian resentments. Only recently have analysts underscored the religious dimensions of the Syrian conflict that in microcosm reflect larger intra-Muslim regional divisions. ${ }^{59}$

Bitter memories of Hafez al-Assad's brutal repression of the Sunnisupported Muslim Brotherhood revolt in the early 1980s persist. The 1980s conflict reached a terrifying conclusion when Hafez al-Assad's regime killed more than 10,000 Muslim Brotherhood supporters (mainly civilians) in the organization's Hama stronghold. ${ }^{60}$ Many of the 2011 protesters evoked the memory of those supporters who died at Hama. It also made an indelible impression on the current regime, whose successor is the son of Haffez al-Assad-who, like his father, believes in the utility of brute force.

The Assad dynasty's efforts to promote pan-ethnic nationalism, furthermore, angered the Kurds, who form 10-15 percent of the population. Kurdish autonomy in Iraq rekindled ethnic separatism in Syria. ${ }^{61}$ The Kurds and Damascus have had an ambiguous relationship characterized by mutual and divergent interests. ${ }^{62}$ These sectarian and ethic antagonisms have persisted over time, aggravating the civil war.

Samuel P. Huntington's maligned clash of civilization thesis has resurfaced with a vengeance across the Middle East. ${ }^{63}$ Regional confessional conflicts also have been fueled by external developments that have been building. Forty years of Iranian patronage and support for Shia and affiliated minorities in Lebanon, Yemen, Bahrain, Syria, and Iraq has run up against its sectarian antithesis of Saudi-financed Muhammad ibn 'Abd al-Wahhab's Sunni extremism. Today, the two nations fight a shadow war across the region. ${ }^{64}$

Sectarian conflicts have contributed to governmental instability across the Middle East. The fall of regimes in Tunisia and Egypt during the Arab Spring 
movement created extreme anxiety among regional leaders. Violent sectarian cleavages and a weakened regime have converged in Syria's political upheaval.

Faced with regime change, Bashar al-Assad responded with a brutal 2011 crackdown, converting a nonviolent protest movement into a virulent insurgency. The regime's murder of four young graffiti artists in March 2012 resulted in a mass oppositional movement. Hundreds of protesters were arrested. ${ }^{65}$ Many were tortured and killed. Faced with little prospect of peaceful change, the rebellion became increasingly violent. Syria's fragile ethnosectarian tinderbox and Damascus's repression has triggered a violent Sunni insurgent movement. By late 2012, armed rebellion against the Assad regime spread across the country. Many Sunni-dominated regions fell to rebel forces.

By 2013, Damascus was reeling under the strain of fighting a rebel movement supported by the Sunni majority. Assaults by secular and Islamist rebel groups supported by the Western powers (including the United States, France, and the United Kingdom), Turkey, and Arab Gulf States were beginning to take their toll. Without outside assistance, the regime was unlikely to survive.

With the exception of a few strategic military bases, Syria's eastern frontier with Iraq was abandoned, allowing rebel forces to capitalize on the resulting power vacuum. Having captured territory in northwestern Iraq in 2013, ISIS forces surged across the border and displaced other rebel groups. The caliphate's forces came to govern the region with the Euphrates town of ar-Raqqa serving as its administrative capital. ${ }^{66}$ Damascus ceded control over Kurdish-dominated areas of Syria, contributing to the rise of the Syrian Democratic Union Party (PYD) and its YPG military branch.

Iran and Hezbollah's historic alignment with the Assad regime as an axis of resistance against Israel convinced them to intervene in the conflict. Hundreds of IRGC trainers and thousands of Lebanese Hezbollah militiamen defended the regime, reversing rebel gains and stabilizing Assad's position in major cities and in coastal Latakia.

Tehran recruited and armed approximately 40,000 Iraqi, Pakistani, and Afghan Shia volunteer militia members to defend the regime. ${ }^{67}$ Combined with Hezbollah, this Shia expeditionary force strengthened the regime army and militia units. Augmented militarily, the regime secured key regions. The Syrian army and Hezbollah's summer 2013 offensive dislodged rebel forces from Qusayr and secured supply lines linking Damascus, Aleppo, and coastal Latakia. $^{68}$

\section{Russian Hybrid Warfare in Syria}

Iran, Hezbollah, and Russia supplied Assad's regime with critical weapons, supplies, and manpower to bolster its military position. ${ }^{69}$ Despite Iranian and 
Hezbollah assistance, the regime security forces experienced severe manpower shortages. By summer 2015, rebel groups were making advances in Latakia, Idlib, and Hama provinces.

In September 2015, Russia dramatically increased its military involvement by launching air strikes against Syrian rebels fighting Assad's regime. Hoping to prevent the regime's deterioration, Russia deployed its armed forces in Syria. With 2,000 support personnel, Moscow became an active participant in Syrias civil war. ${ }^{70}$ Though Putin justified his military intervention as part of the international anti-IS military campaign, his strategic goals in Syria lay elsewhere. ${ }^{71}$

The Kremlin hoped to reinforce the Assad regime's military position and fortify the Russian-Iranian-Shiite regional sphere of influence to blunt Western interests. Its Syrian policy was part of a strategy of reinvigorating Russia’s presence in the Mediterranean and weakening America's historic regional dominance. ${ }^{72}$ Even more pressing was the need to keep thousands of Russian-born Islamic terrorists in Syria from returning to their homeland and preserving Russia’s naval base in Tartus.

Such a commitment is not surprising. Syria and Russia have had a strategic relationship dating back to the Cold War. Since its entry into the civil war, hundreds of Russian air strikes have targeted anti-Assad rebels, helping the regime retake towns and villages near Aleppo and Latakia. The majority of the Russian bombs dropped have been against Western-backed moderate rebels. The Institute for the Study of War reports that 90 percent of Russia's air strikes are concentrated in northwestern Syria outside areas controlled by IS. ${ }^{73}$ Government forces in 2016 encircled rebels in Aleppo, forcing a negotiated withdraw of their remaining forces.

The recapture of rebel-held Aleppo in 2017 proved to be a critical turning point in the civil war. ${ }^{74}$ The government's offensive to create a corridor linking Damascus, Aleppo, and Alawite northern coastal bastions has succeeded. Assistance from Hezbollah and IRGC units and Iraqi, Afghan, and Pakistani Shiite militias helped strengthen Assad's regime. Damascus ensured its survival through merciless brutality. Government forces eviscerated rebel-supported neighborhoods in Aleppo, killing thousands of civilians by dropping barrel bombs packed with gasoline and nails. The war has featured the use of chemical weapons that have killed thousands. ${ }^{75}$ By 2018, close to a half a million people have died and 11 million have been displaced..$^{76}$ Remaining rebel positions in Idlib Province and southern Syria are under extreme military pressure.

Russia's hybrid warfare has been perfected in Syria and may be a prototype for future use. The Kremlin's overall investment and commitment have been modest. Though cloaked in secrecy, its casualties have been low, with Russian mercenaries and regime/allied forces experiencing the greatest losses. ${ }^{77}$ Russia’s 
Syrian military gambit has ensured that the Assad regime remains a viable strategic partner. The Kremlin is well positioned to benefit from oil and gas development and reconstruction projects in post-civil war Syria.

Its Tartus naval base allows it access to warm-water ports and strategic depth in the Mediterranean. Based on its success in Syria, Russia appears interested in forging economic and military relationships with the Egyptian government and has been actively exploring access to deep-water ports in Libya and gaining a foothold on the country's oil and gas development. Russia's hybrid warfare combines a disinformation campaign with brutality. Packaged as a counterterror policy against IS, the Kremlin has pursued its overriding strategic interests with savage precision and strategic logic. ${ }^{78}$ Though it supported the Assad regime's efforts to dislodge IS from the Deir ez-Zor region, the bulk of its bombs have been dropped on secular and Islamist rebels not affiliated with IS.

Describing Assad's opponents as terrorists, Russian air strikes have targeted civilian populations and destroyed hospitals, food storage sites, and water infrastructure. It has supported regime efforts to starve, bomb, and bludgeon opposition forces into submission. The Kremlin disinformation campaign denies that civilians have been killed, labeling the allegations as rebel propaganda. ${ }^{79}$

Putin's regime has refined the art of talking peace while practicing war. ${ }^{80}$ Central to the Kremlin's disingenuous campaign have been the diplomatic efforts of Russia's foreign minister Sergei Lavrov. He has promoted various peace initiatives at Geneva, signed cease-fire accords, sponsored humanitarian evacuation agreements, and endorsed the demarcation of deescalation zones separating combatants. Russia has honored none of these agreements. ${ }^{81}$

Lavrov forged a Russian, Turkish, and Iranian alliance to end the civil war and has brokered conferences hosted by the capital city of Astana, Kazakhstan, that have eclipsed the efforts of Geneva negotiators more attuned to Western interests. Lavrov's diplomatic posturing provides Russia with sufficient cover to relentlessly bomb Assad's opponents and support regime ground operations against rebel forces. ${ }^{82}$

Faced with air strikes against the civilian population, rebels cannot effectively use human shields. The destruction of health, water, and food systems makes life untenable in rebel-controlled areas. Regime brutality is designed to bludgeon the population into submission and undermine their support for rebels. Increasingly, rebel presence is resented in areas hit by mass bombardment. Hard-core jihadist groups like al-Qaeda associate Hayat Tahrir al-Sham (HTS) are forced to sign humiliating evacuation agreements because their guerrilla warfare strategy has failed to effectively combat the advanced weaponry of regime forces and their allies. ${ }^{83}$ Jihadists are flummoxed and powerless to combat such tactics. Faced with the nonutility of civilian shields, Islamist rebels have little opportunity to effectively resist and are forced into ignominious retreat. 
This is not the first time Islamic extremists have failed to effectively respond to a superpower's use of hybrid warfare techniques. Jihadist theoretician Abu Musab al-Suri, for example, recognized al-Qaeda's incapacity to effectively counter the U.S. military's post-9/11 military campaign in Afghanistan. ${ }^{84}$

Moscow's effective military strategy could force rethinking the utility of a counterinsurgency strategy based on protecting the civilian population popular in American counterinsurgency manuals. These lessons have not been lost on U.S. strategic planners in Iraq and Syria, especially when fighting a brutal opponent like IS. Increasingly, American military policy in Syria is showing less concern for the loss of civilian life, and its use of Kurdish and Arab proxies provide sufficient cover to deflect criticism of collateral damage. ${ }^{85}$

\section{U.S. Hybrid Warfare Policy in Syria}

The development of a U.S. hybrid warfare policy in Syria reflects fortuitous circumstances and past bitter experiences. The approach effectively balances fear of another Middle East quagmire while recognizing the region's strategic importance. The strategy, moreover, is a response to the costs of past counterinsurgency policy in Iraq and Afghanistan and the need to have a more sustainable regional military policy. American hybrid war policy in Iraq and Syria came after America's failed bid to militarily disengage from the region. ${ }^{86}$ The Obama administration in 2011 harbored fantasies that the United States could pivot out of the region toward Asia. It did so at the very worst time, for its pivot coincided with the Arab Spring's turmoil.

Nascent democracies in Tunisia and Egypt, far from disempowering extremist groups, weakened security services, and their mass prisoner releases fueled jihadi ranks. Civil wars in Yemen, Libya, Syria, and Iraq unleashed Islamist organizations committed to violent jihad and the upending of regional political order. Having withdrawn from Iraq in 2011, the American administration was overly optimistic that Baghdad's security services could repress the jihadist threat. Faced with the emergence of a reinvigorated Islamic State of Iraq (ISI) that steadily captured territory in Iraq and Syria, the administration hoped to rely on a containment strategy. ISI's caliphate proclamation in June 2014, however, sent shock waves across the region.

Self-proclaimed as the Islamic State, the caliphate's forces reached Erbil and Baghdad's outskirts, threatening the collapse of the Iraqi state. President Barack $\mathrm{H}$. Obama's efforts at maintaining a minimalist regional policy were dashed by the caliphate's military advances and its ethnic cleansing of the Yazidi population. ${ }^{87}$ Massive population flows caused by IS's capture of much of northwestern Iraq, moreover, threatened neighboring states and Europe.

Confronted with an immense strategic and humanitarian disaster, the administration reluctantly intervened by marrying U.S. air power with local part- 
ners who would confront IS in Iraq and eventually in Syria. ${ }^{88}$ By avoiding a mass commitment of American ground troops, the administration hoped to develop a more sustainable counterterrorism policy. Its past success with drone warfare and special operations actions against al-Qaeda and its regional branches were seen by administration planners as a viable precursor.

By barring the U.S. military from ground combat against IS militants, the U.S. administration hoped to manage the political fallout of being drawn into another regional conflict. After some initial confusion, by 2015, the administration pursued a policy of degrading and destroying IS's state-building project. American air strikes targeted the caliphate's troop concentrations and its strategic logistical nodes. Assisting local forces with air operations, the United States hit the caliphate's transport and energy infrastructure.

The Americans hoped to eviscerate the caliphate's finances by bombing IS's oil and gas operations. ${ }^{89}$ Since 2014, the U.S. Air Force has dropped thousands of bombs on IS positions, which depleted its manpower and support structure. Four years of Coalition attacks left approximately 40,000 IS foot soldiers dead. ${ }^{90}$

Relentless aerial bombardment was supplemented by training and equipping local actors to take the fight to the caliphate across the Iraqi-Syrian territorial divide. By 2015, close to 5,000 American trainers and Special Forces in Iraq were committed to reconstituting Baghdad's beleaguered army units. ${ }^{91}$ Despite the collapse of entire Iraqi divisions to numerically inferior IS forces, the Americans managed to strengthen Iraqi army forces and their Sunni and Kurdish allies. Washington put emphasis on reinvigorating Iraq's Counter Terrorism Service to lead the fight against IS militants. ${ }^{92}$ A preexisting Iraqi government made the choice of local partner easy.

Syria, however, was a different matter. Though the Obama administration was forced into cooperation with Damascus's ally, Russia, formally assisting the Syrian government was not a viable option. Having called for Assad's removal, the administration assisted the opposition Free Syrian Army (FSA). It also tasked the CIA and Pentagon to train and equip vetted anti-Assad brigades and find a credible Arab partner. Throughout 2014-15, the U.S. government failed to empower such "brigades" that were either easily defeated in combat or co-opted by jihadist groups. ${ }^{93}$

Finding a capable Arab force to fight IS in Syria was similarly illusive. Under military pressure from IS, the YPG became America's logical ally to fight the caliphate's forces. $^{94}$ The YPG's political branch, the PYD, envisioned a Kurdish autonomous area named Rojava, whose territory would stretch across Syria's border with Turkey. The caliphate's military advances in northeastern Syria threatened the SDF's political project to create a contiguous Kurdish area.

Supporting the Kurdish fight against IS in Syria, however, ran the risk of 
Turkish opposition, for Ankara believes the YPG is an extension of the Kurdistan Workers' Party terror network whom it has fought for decades. Faced with the collapse of YPG forces defending the border city of Kobane, the Obama administration launched air strikes against the caliphate's soldiers. The Americans supplemented their airborne operation with arms supplies to the endangered YPG units.

The fight for Kobane left the city in ruins but resulted in the caliphate's first major defeat. Thousands of IS militants were killed by U.S. airstrikes. The Kobane operation began a strategic relationship with the YPG leading to a joint 2015-18 offensive that drove the caliphate's forces from Syria's border with Turkey. ${ }^{95}$ Aided by approximately 3,000 U.S. Special Forces troops, an American Marine Corps artillery brigade, and air strikes, the YPG supported U.S. policy to degrade and destroy the Islamic State's geomilitary position in Syria.

The Obama administration attempted to put a panethnic veneer on its Kurdish proxy force by creating the SDF that incorporated Arab brigades within the YPG's military structure. ${ }^{96}$ Such an initiative was driven by many factors. First, the destruction of the caliphate's forces necessitated the projection of force beyond Kurdish-dominated areas and into the Arab heartland. Without Arab allies, the YPG may have encountered fierce resistance by Sunni tribes. Second, the SDF's creation hoped to placate Turkish and Arab concerns about Kurdish ethnic cleansing in the areas that the YPG occupied.

The SDF became a convenient pretext to justify the YPG's presence in Arabmajority areas. ${ }^{97}$ Given the military dominance of the Kurds and the SDF's small numbers of Arab fighters, few were convinced by Washington's characterization of the SDF as a panethnic force. Eager to finalize military operations against the caliphate, the Trump administration relaxed Obama-era restrictions on bombing and brazenly airlifted Kurdish forces to facilitate anti-IS operations. $^{98}$

Though more focused than Russia's bombing campaign, civilian casualties due to U.S. air strikes increased rapidly. The military was given more freedom in targeting IS's crumbling geomilitary position. Air strikes increased in frequency and scale, facilitating the YPG's march on IS's capital in ar-Raqqa. By October 2017, U.S.-YPG forces besieged ar-Raqqa, and after a four-month battle, remaining IS forces and their families withdrew under a negotiated agreement. ${ }^{99}$ The city was devastated, leaving UN and human rights agencies criticizing the Trump administration's indiscriminate bombing campaign. ${ }^{100}$ Unmoved by the denunciations, the American military continued the pace of its air operations by targeting IS's remaining positions around Deir ez-Zor and the Euphrates River Valley. The caliphate headquarters in al-Mayadin fell rapidly as IS diehard militants increasingly turned to guerrilla operations against YPG units. ${ }^{101}$

Success against the caliphate, however, aggravated American-Turkish rela- 
tions. Kurdish territorial advances west of the Euphrates River Valley stretched into Arab-speaking areas that violated Ankara’s stated opposition. By late 2017, Turkey threatened to intercede into the Syrian conflict to stem Kurdish advances. ${ }^{102}$ The Obama administration had walked a fine line, illusively trying to harmonize its desire to militarily degrade the caliphate in Syria while appeasing Turkish concerns. The Trump administration's later proposal for a Kurdish security zone along the Turkish border angered Ankara.

By March 2018, YPG advances into Manbij threatened to link Kurdish areas between Afrin and Jarabulus. Shortly thereafter, Turkish forces and their FSA allies stormed across the border to drive the YPG from Afrin. Since the operation, Ankara has threatened further incursions into Kurdish-speaking areas. Given the intermixing of American and Kurdish military units, Turkish incursion into Manbij endangers U.S. troops. Cognizant of the dangers, the Trump administration in June 2018 reached a power-sharing arrangement in Manbij between Arab and Kurdish interests to placate Ankara's concerns. ${ }^{103}$

Turkey's seizure of Afrin was unopposed by the Americans, who did not defend Kurdish positions. The YPG was forced to redeploy troops to resist further Turkish and FSA operations. Faced with Ankara's opposition to its Syrian policy and the YPG's need to deprioritize the fight against IS in the Euphrates River Valley, Washington has struggled to find a solution. President Trump's inconsistency on withdrawing American troops in Syria has furthered exacerbated Turkish and Kurdish anxieties.

The American military presence in Manbij, however, is a potent message to Ankara that further incursions into Kurdish areas risks confrontation with U.S. military forces. Convinced that Washington is committed to defending Kurdish interests, the YPG is ready to renew the fight against remaining IS forces. After an operational pause, the YPG in May 2018 renewed its attack on the caliphate's forces close to the Iraqi border. Whether this moves Ankara toward additional military advances into YPG-held areas is difficult to discern. Syria has become an arena for regional and superpower competition that could presage a wider military confrontation. Managing this rivalry will prove challenging.

Nations in Syria are pursuing a classic realpolitik strategy, empowering allies and weakening enemies. This rivalry harkens back to philosophical conceptions of realism that diverge sharply from its conventional meaning. Regional and international use of realpolitik in Syria respects the utility of brute military force to advance strategic geopolitical interests.

Under its hybrid form, nation-state competition in Syria employs hard and soft measures. It furthermore mixes conventional and proxy forces coupled with information/disinformation strategies. With Turkish, American, French, British, Iranian, and Russian troops and their allies supporting contending factions in Syria's multipolar civil war, the danger of escalation is omnipresent. 


\section{Superpower Competition and Deconfliction in Syria}

Despite supporting opposing sides in the civil war, the Americans and Russians do have common interests in defeating jihadist groups. Combating Islamist extremism serves as a rationale for their military interventions. Russian and American air power was mobilized to destroy terror sanctuaries in Syria and deny jihadi groups a major safe haven. The Kremlin further justified its intervention to fight approximately 3,000 Russian jihadists in Syria to ensure they never return home. ${ }^{104}$

Beyond the stated mission of destroying the Islamic State, the Americans have targeted former al-Qaeda affiliate Jabhat al-Nusra's (or al-Nusra Front) Khorasan group, fearing that the unit was contemplating using Syria as a launching pad for terrorist actions against the West. ${ }^{105}$ The Americans and Russians have bombed and assassinated high-level commanders in IS- and al-Qaeda-affiliated groups. ${ }^{106}$

The use of Syrian airspace by American and Russian aircraft to attack jihadi groups necessitated joint communication structures to coordinate military actions. Such cooperation was viewed by the Obama administration as a means to reset the American relationship with Russia, which was strained by the Kremlin's Ukraine policy. Additionally, Washington and Moscow spearheaded the Geneva-based peace process designed to end the Syrian civil war. The Obama administration hoped that Moscow could use its influence with the Syrian regime to convince Bashar al-Assad to agree to a democratic transition and end the conflict. ${ }^{107}$ Assad's intransigence and Russia's disingenuous diplomacy soon dashed such hopes. Neither Moscow nor Damascus took the Geneva negotiations seriously and used the forum as a convenient cover to bomb the opposition into submission. ${ }^{108}$

Negotiated cease-fires were repeatedly broken by Syrian forces and their allies. Throughout the Obama administration, Putin's regime played their American antagonists masterfully. ${ }^{109}$ The Assad regime's use of chemical weapons in August 2013 - killing more than a thousand people in eastern Damascus_-violated the Obama administration's "red line" forbidding the use of such arms. ${ }^{110}$ As the administration prepared retaliatory military strikes against Assad's chemical weapons infrastructure, Moscow convinced Washington to agree to an internationally supervised plan to disinvest Assad of his weapons of mass destruction stockpiles. ${ }^{111}$ Under the proposal, the regime's declared stockpiles would be guaranteed by Moscow and shipped out of the country and destroyed.

Seeing Moscow's initiative as a means to avoid being drawn militarily into another Middle East quagmire, the U.S. administration called off its planned airstrikes. During a journalist's interview, Barack Obama indicated that backing down from the planned strikes was his finest moment. ${ }^{112}$ Given the regime's subsequent use of chemical weapons, the 2013 agreement clearly failed. 
Assad's fraudulent stockpile declarations and the 2013 chemical weapons disarmament plan were good examples of the Kremlin's use of reflexive control to shape opponents' actions toward a desired end state. ${ }^{113}$ Moscow's proposal ensured the Assad regime was protected from debilitating military strikes and demonstrated to the world that Washington lacked resolve. By not enforcing its own red line, the American administration lost all credibility. Not surprisingly, the Russians, Iranians, and Hezbollah increased their intervention in the Syrian conflict. ${ }^{114}$ The crisis in American resolve also was exacerbated by the Obama administration's call to remove the Assad regime from power and its inability to enforce this objective.

Russia's targeting of Western-backed rebels undermined Washington's policy of pressuring Assad to step down. Having failed to secure a larger resolution of the civil war, the Obama administration narrowed its Syrian policy to weakening IS- and al-Qaeda-affiliated networks. Despite the Trump administration's critique of Obama's Syrian policy, it has retained its limited counterterrorism strategy.

By spring 2018, the IS's military position in Syria had collapsed and its presence was confined to the Euphrates River Valley. While America's policy of hybrid warfare did significantly erode the caliphate forces, success brought other problems. The mixing of U.S. Special Forces with the YPG units augurs the possibility that they could be attacked by Russian, Turkish, or Iranian-backed proxy forces. National armies and their proxies are competing to partition Syria into rival spheres of territorial control. Cognizant that this competition could portend major armed conflict, the parties have constructed ad hoc agreements designed to separate the antagonists. These informal arrangements have at times broken down.

Faced with Shia militia attacks on YPG positions, the United States in June 2017 launched air strikes killing dozens of Hezbollah militants. That military response, however, did not deter Iranian and Russian forces in February 2018 from violating preapproved Kurdish positions in Deir ez-Zor. The American retaliatory assault killed hundreds of Russian mercenaries and IRGC members. ${ }^{115}$ Both attacks reinforced Washington's determination to preserve its Kurdish proxy force as a counterweight to Iranian-Hezbollah-Russian influence in the area.

With Turkish troops' seizure of Afrin in 2018, Washington faces the prospect that it may have to punish Ankara if it deepens its military campaign. Given the incorporation of American Special Forces in the YPG's ranks, further Turkish incursions threaten Washington's interests. How Ankara may respond if the Americans bomb Turkish troops is anyone's guess.

The Trump administration's commitment to maintain America's deterrent capability recovers U.S. credibility lost after his predecessor failed to enforce 
the red line over the Assad regime's use of chemical weapons. Damascus's later employment of chemical weapons was met with American determination. U.S., French, and British jets bombed Assad's chemical weapons facilities in April 2018 in retaliation for Damascus's use of chemical weapons against rebels. ${ }^{116}$

Trump has built a Western coalition committed to a policy of gradual escalation to deter the regime's future use of chemical weapons. The limited scale of the American air campaign to degrade Assad's weapons of mass destruction capabilities has sent a message to Damascus that the United States is uninterested in regime change.

It is also a signal to Moscow that Washington does not want to risk confronting Russian forces, as wider strikes could endanger hitting Russian troops embedded in regime forces. West Point's CTC Sentinel once described the Syrian civil war as wicked problem for all and the intervention of Iranian, Turkish, Russian, and American forces risk a regional war. ${ }^{117}$ Israel's air campaign to degrade Hezbollah and Iranian missile capabilities adds further complexity to the conflict. So far, the parties involved in the Syria conflict have managed to avoid a wider conflagration. Their luck may run out.

Beyond the defeat of IS and the preservation of its Kurdish proxy force as a counterweight to Iran, the Trump administration has little strategic interest in Syria. ${ }^{118}$ Its ambiguous statements of withdrawing American troops from the country underscore its restricted counterterrorism focus. Aided by Russian airpower, the Assad regime's assault on rebel positions in Idlib Province threatens al-Qaeda associate HTS. Within this context, U.S.-Russian cooperation to uproot jihadist infrastructures facilitates mutual strategic interests.

Moscow's interests in Syria, however, are considerable. Putin had secured the Assad regime's survival and brought Turkey into its sphere of influence by capitalizing on President Recep Tayyip Erdogan's anti-Western resentments. Russian-Iranian-Turkish patronage of negotiations at the Kazakh city of Astana in 2017 excluded the United States as a major power broker over Syria's future. ${ }^{119}$ The Astana initiative has provided convenient diplomatic cover for the parties to ruthlessly pursue their strategic interests. With its air and naval installations in Syria, Moscow has achieved greater strategic depth in the Middle East. Not since Soviet forces were expelled from Egypt in 1971 has Russia achieved such regional geopolitical prominence.

In stark contrast, the Trump administration has pursued a minimalist strategy in Syria. Focused on denying jihadist groups a terror safe haven and deterring the use of chemical weapons, Washington has indicated to major actors in Syria its limited ambitions. It has, however, demonstrated its willingness to employ military force against the Assad regime and Russian and Iranian interests to enforce this limited policy.

Opposing interests and competing zones of influence in Syria require mul- 
tiparty communication to prevent escalation. Washington and Moscow in Syria are entering uncharted territory. Navigating the inherent tensions of superpower involvement in Syria will require nimbleness and resolve. Thus far, the Trump and Putin administrations have managed to reconcile their competing interests. Whether they can contain the ambitions and antagonistic agendas of their allies is another matter.

\section{Notes}

1. Andrew Radin, Hybrid Warfare in the Baltics: Threats and Potential Responses (Santa Monica, CA: Rand, 2017), https://doi.org/10.7249/RR1577.

2. Michael A. Reynolds, Outfoxed by the Bear?: America's Losing Game against Russia in the Near East (Philadelphia: Foreign Policy Research Institute, 2018).

3. Bilal Wahab and Jackson Doering, "Managing the Shift in Relations with Syria's Kurds," Policy Watch 2899, Washington Institute for Near East Policy, 8 December 2017.

4. "968 SDF Fighters Killed Fighting ISIS, Turkey in 2017," Rudaw, 1 April 2016.

5. Anna Borshchevskaya, "Moscow's Middle East Resurgence: Russia’s Goals Go Beyond Damascus," Middle East Quarterly 25, no. 1 (Winter 2018); and Christopher Kozak, "The Strategic Convergence of Russia and Iran," Institute for the Study of War, 24 February 2017.

6. Kareem Shaheen, "String of Losses in Syria Leaves Assad Regime Increasingly Precarious," Guardian, 11 June 2015.

7. Fabrice Balanche, "Preventing a Jihadist Factory in Idlib Province," Policy Watch 2856, Washington Institute for Near East Policy, 31 August 2017.

8. David H. Ucko, "Regimes and Revolts: Authoritarian Ways of Counterinsurgency," War on the Rocks (blog), 20 January 2016.

9. Robert E. Hamilton, Russian-American De-Confliction Efforts in Syria: What's the Endgame in the Civil War (Philadelphia: Foreign Policy Research Institute, 2018).

10. Jackson Doering, "Washington's Militia Problem in Syria Is an Iran Problem," Policy Watch 2932, Washington Institute for Near East Policy, 19 February 2018.

11. Ehud Yaari, "Bracing for an Israel-Iran Confrontation in Syria," American Interest, 30 April 2018.

12. Joshua Krasna, "Winds of War: Tensions between Israel and Iran Are at a Boiling Point," Geopoliticus (blog), 10 May 2018.

13. Krasna, "Winds of War."

14. Dmitri Trenin, "Avoiding U.S.-Russia Military Escalation during the Hybrid War," Carnegie Endowment for International Peace, 25 January 2018.

15. Hamilton, Russian-American De-Confliction Efforts in Syria.

16. Frank G. Hoffman, Conflict in the 21st Century: The Rise of Hybrid Wars (Arlington, VA: Potomac Institute for Policy Studies, 2007).

17. Amos Harel and Avi Issacharoff, 34 Days: Israel, Hezbollah, and the War in Lebanon (New York: St. Martin's Press, an imprint of McMillan, 2008).

18. Harel and Issacharoff, 34 Days, 14.

19. Radin, Hybrid Warfare in the Baltics, 5.

20. Radin, Hybrid Warfare in the Baltics, 5.

21. Emilio J. Iasiello, "Russia's Improved Information Operations: From Georgia to Crimea," Parameters 47, no. 2 (Summer 2017): 51-63.

22. Iasiello, "Russia’s Improved Information Operations," 51.

23. Trenin, "Avoiding U.S.-Russia Military Escalation during the Hybrid War."

24. Robert D. Kaplan, Imperial Grunts: The American Military on the Ground, from Mongolia to the Philippines to Iraq and Beyond (New York: Vintage Books, 2006).

25. Zarena Aslami, "The Second Anglo-Afghan War, or the Return of the Uninvited," BRANCH: Britain, Representation and Nineteenth-Century History (August 2012). 
26. Neil Faulkner, Lawrence of Arabia's War: The Arabs, the British and the Remaking of the Middle East in WWI (New Haven, CT: Yale University Press, 2016).

27. Michael Eisenstadt, The Strategic Culture of the Islamic Republic of Iran: Operational and Policy Implications, Middle Eastern Studies Monograph Series no. 1 (Quantico, VA: MCU Press, 2015).

28. Eisenstadt, The Strategic Culture of the Islamic Republic of Iran.

29. Vali R. Nasr, The Shia Revival: How Conflicts within Islam Will Shape the Future (New York: W. W. Norton, 2006).

30. "Why Is There a War in Syria," BBC News, 7 September 2018.

31. Eisenstadt, The Strategic Culture of the Islamic Republic of Iran.

32. Matthew Levitt, Hezbollah: The Global Footprint of Lebanon's Party of God (Washington DC: Georgetown University Press, 2013).

33. Joshua L. Gleis, Withdrawing Under Fire: Lessons Learned from Islamist Insurgencies (Washington, DC: Potomac Books, 2011), 79-122.

34. Harel and Issacharoff, 34 Days.

35. Yaari, "Bracing for an Israel-Iran Confrontation in Syria."

36. Marisa Sullivan, Hezbollah in Syria, Middle East Security Report 19 (Washington, DC: Institute for the Study of War, 2014).

37. Michael Eisenstadt, "Has the Assad Regime 'Won' Syria's Civil War?'," Washington Institute for Near East Policy, 29 May 2018.

38. Hassan Mneimneh, "Washington Should Recognize the Russian Strategic Achievement in Syria," Washington Institute for Near East Policy, 29 May 2018.

39. Hanin Ghaddar, "Iran's Foreign Legion: The Impact of Shia Militias on US Foreign Policy," Washington Institute for Near East Policy, February 2018.

40. James M. Dubik and Nic Vincent, "America's Global Competitions: The Gray Zone in Context," Institute for the Study of War, February 2018.

41. Dubik and Vincent, "America’s Global Competitions," 9.

42. Brian Fishman, Dysfunction and Decline: Lessons Learned from Inside Al Qaida in Iraq (West Point, NY: Combating Terrorism Center at West Point, 2009).

43. Peter L. Bergen, The Longest War: The Enduring Conflict between America and Al-Qaeda (New York: Simon \& Schuster, 2011), 57-67.

44. Radin, Hybrid Warfare in the Baltics; and Keir Giles, Russias' "New" Tools for Confronting the West: Continuity and Innovation in Moscow's Exercise of Power (London: Royal Institute of International Affairs_Chatham House, 2016).

45. Radin, Hybrid Warfare in the Baltics.

46. Charles K. Bartles, "Getting Gerasimov Right," Military Review, January-February 2016.

47. Maria Snegivaya, "Putin's Information Warfare in the Ukraine: Soviet Origins of Russia's Hybrid Warfare," Institute for the Study of War, 1 September 2015.

48. Radin, Hybrid Warfare in the Baltics.

49. Radin, Hybrid Warfare in the Baltics; and Giles, Russia's "New" Tools for Confronting the West.

50. The term Euromaidan refers to the protest movement that took place in Ukraine during 2014. The group supported the European integration of Ukraine.

51. Adrian A. Basora and Aleksandr Fisher, "Putin's 'Greater Novorossiy'-The Disarmament of Ukraine," Foreign Policy Research Institute of Philadelphia, 2 May 2014.

52. Radin, Hybrid Warfare in the Baltics.

53. Iasiello, "Russia's Improved Information Operations."

54. Giles, Russia's "New" Tools for Confronting the West.

55. Giles, Russia's "New" Tools for Confronting the West.

56. Catherine Harris and Frederick W. Kagan, "Russia’s Military Posture: Ground Forces Order of Battle," Institute for the Study of War, 7 March 2018.

57. "Why Is There a War in Syria."

58. Tony Badran, "Syria’s Assad No Longer in Vogue: What Everyone Got Wrong about Bashar al-Assad," Foreign Affairs, 25 March 2011. 
59. Samuel Helfont, "The Geopolitics of the Sunni-Shia Divide," FPRI Footnote, December 2013; and Steven Hydemann, Syria's Uprising: Sectarianism, Regionalisation, and State Order in the Levant (The Hague, Netherlands: Fride and Hivos, 2013).

60. Thomas L. Friedman, "Hama Rules," in From Beirut to Jerusalem, 2d ed. (London: HarperCollins, 1998), 76-105.

61. Fabrice Balanche, Sectarianism in Syria's Civil War: A Geopolitical Study (Washington, DC: Washington Institute for Near East Policy, 2018).

62. Anna Borshchevskaya, "Russia, Syrian Kurds, and the Assad Regime," in Syrian Kurds as a U.S. Ally: Cooperation and Complications, ed. Patrick Clawson (Washington, DC: Washington Institute for Near East Policy, 2016).

63. Samuel P. Huntington, The Clash of Civilization and the Making of World Order (New York: Simon \& Schuster, 1996).

64. The Wahhabi religious movement is a fundamentalist Islamic order that advocates a strict interpretation of the teachings in the Koran.

65. "Why Is There a War in Syria?"

66. Aymenn al-Tamimi, "The Evolution in Islamic State Administration: The Documentary Evidence," Perspectives on Terrorism 9, no. 4 (2015): 117-29.

67. Ghaddar, "Iran's Foreign Legion."

68. Jeffrey White, "Assad's Indispensable Foreign Legions," Washington Institute for Near East Policy, 22 January 2014.

69. Jeffrey White, "Hizb Allah at War in Syria: Forces, Operations, Effects and Implications," CTC Sentinel 7, no. 1 (January 2014).

70. Hugo Spalding et al., "Russia’s Deployment to Syria: Putin's Middle East Game Changer," Warning Intelligence Update (blog), Institute for the Study of War, 17 September 2015.

71. Spalding et al., "Russia's Deployment to Syria."

72. Borshchevskaya, "Moscow's Middle East Resurgence."

73. Hugo Spalding, "Russia's False Narrative in Syria," Backgrounder (blog), Institute for the Study of War, 1 December 2015.

74. $\quad$ Eisenstadt, "Has the Assad Regime 'Won' Syria's Civil War."

75. Aron Lund, "Red Line Redux: How Putin Tore Up Obama's 2013 Deal," Century Foundation, 3 February 2017.

76. "Why Is There a War in Syria?"

77. Borshchevskaya, "Moscow's Middle East Resurgence."

78. Maksymilian Czuperski et al., Distract, Deceive and Destroy: Putin at War in Syria (Washington, DC: Atlantic Council, 2016).

79. Czuperski et al., Distract, Deceive and Destroy.

80. Reynolds, Outfoxed by the Bear?

81. Czuperski et al., Distract, Deceive and Destroy.

82. Daniel Byman, "Death Solves All Problems: The Authoritarian Counterinsurgency Toolkit," War on the Rocks (blog), 3 February 2016.

83. Aymenn Jawad al-Tamimi, "Success for al-Qaeda in Syria?," Perspectives on Terrorism 11, no. 6 (2017).

84. Brynjar Lia, Architect of Global Jihad: The Life of Al-Qaida Strategist Abu Mus'ab al-Suri (Oxford: Oxford University Press, 2009).

85. Bill Roggio and Alexandra Gutowski, "2017: A Record Year for Counterterrorism Strikes," Long War Journal, 3 January 2018.

86. Steven P. Cohen and Robert Ward, "Asia Pivot: Obama's Ticket out of the Middle East?," Brookings Institution, 21 August 2013, op-ed.

87. The Yazidis are members of a Kurdish religious minority found primarily in northern Iraq, southeastern Turkey, and northern Syria. Helene Cooper, Mark Landeer, and Alissa J. Rubin, “Obama Allows Limited Airstrikes on ISIS," New York Times, 7 August 2014.

88. Michael Eisenstadt, "Defeating ISIS: A Strategy for a Resilient Adversary and an Intractable Conflict," Washington Institute for Near East Policy, Policy Notes 20, November 2014 . 
89. Ludovico Carlino, “The IS Economy: Will Losing Territory Cripple the Islamic State?," Terrorism Monitor 15, no. 23 (December 2017).

90. Mohammad Hafez, "The Curse of Cain: Why Fratricidal Jihadis Fail to Learn from Their Mistakes," CTC Sentinel 10, no. 10 (November 2017): 1-7.

91. James Jeffrey and Michael Eisenstadt, "U.S. Military Engagement in the Broader Middle East," Washington Institute for Near East Policy, Policy Focus 143, Spring 2016.

92. David M. Witty, The Iraqi Counter Terrorism Service (Washington, DC: Brookings Center for Mideast Policy, 2015).

93. Reynolds, Outfoxed by the Bear?

94. Patrick Clawson, "U.S. Policy and the PYD," in Syrian Kurds as a U.S. Ally, 52-59.

95. Hafez, "The Curse of Cain."

96. Farbrice Balanche, "Arabs in the PYD Controlled Area," in Syrian Kurds as a US Ally, 29-38.

97. Balanche, "Arabs in the PYD-Controlled Area," in Syrian Kurds as a U.S. Ally, 29-38.

98. Roggio and Gutowski, "2017."

99. Jim Muir, “'Islamic State': Raqqa's Loss Seals Rapid Rise and Fall,” BBC News, 17 October 2017.

100. Nadim Houry, "A Year on, Fog of War Not Lifting over Deadly Raqqa Stikes," Human Rights Watch, 9 March 2018.

101. Hasan Hasan, "Insurgents Again: The Islamic State's Calculated Reversion to Attrition in the Syria-Iraq Border Region and Beyond," CTC Sentinel 10, no. 11 (December 2017): $1-8$.

102. Barak Bafi, "Containing the Afrin Crisis: Turkey Goals and Military Challenges," Washington Institute for Near East Policy, Policy Watch 2924, 31 January 2018.

103. Aaron Stein, "The Roadmap to Nowhere: Manbij, Turkey and America's Dilemma in Syria," War on the Rocks (blog), 29 June 2018.

104. Richard Barrett, Beyond the Caliphate: Foreign Fighters and the Threat of Returnees (New York: Soufan Center, 2017), 10.

105. Charles Lister, Profiling Jabhat al-Nusra, Brookings Project on U.S. Relations with the Muslim World (Washington, DC: Brookings Institution, 2016).

106. Lister, Profiling Jabhat al-Nusra.

107. Reynolds, Outfoxed by the Bear?

108. Reynolds, Outfoxed by the Bear?, 15.

109. Reynolds, Outfoxed by the Bear?

110. Lund, "Red Line Redux."

111. Lund, "Red Line Redux."

112. Jeffrey Goldberg, "The Obama Doctrine: The U.S. President Talks through the Hardest Decisions about America's Role in the World," Atlantic, April 2016.

113. Adam Garfinkle, "The Chemistry of Syrian Lies and U.S. Credulity Revealed," Foreign Policy Research Institute of Philadelphia, 20 October 2016.

114. Garfinkle, "The Chemistry of Syrian Lies and U.S. Credulity Revealed."

115. Trenin, "Avoiding U.S.-Russia Military Escalation during the Hybrid War."

116. Michael Eisenstadt, "Military Strikes on Syria: Critical Considerations," Washington Institute for Near East Policy, 10 April 2018.

117. Bryan Price, "Syria: A Wicked Problem for All," CTC Sentinel Special Edition Syria 6, no. 8 (August 2013).

118. Aaron Stein, "The 'Adults in the Room' Need to Take Trump Seriously on Syria," War on the Rocks (blog), 10 April 2018.

119. Reynolds, Outfoxed by the Bear?, 13. 


\title{
The Challenge of the Sole Superpower in the Postmodern World Order
}

\author{
Keith D. Dickson
}

\begin{abstract}
To pursue and support its strategic goals and interests, the United States as the sole superpower will require a complete reordering of its assessment of the post-Cold War strategic environment, which is now characterized by the postmodern condition. Recognizing the basic structure of postmodern thought that dominates much of global society and affects concepts of sovereignty, power, war, and peace is essential. Some states and nonstates have already employed a strategic approach that exploits the postmodern condition. Strategists and strategic leaders must now identify the contours of the postmodernist strategic environment to develop a strategic design that allows the superpower to pursue its interests and fulfill its role of order and balance by employing the very skills and precepts that the postmodernists have rejected.
\end{abstract}

Keywords: superpower, strategy, postmodernism, strategic design, strategic environment, war

ince the end of the Cold War, the United States remains the only superpower in that it has no potential strategic competitors and has significantly more capability than any other state to craft a strategy and employ the means of national power to maintain the existing order-support for international norms and the defense of liberal values and human rights. Although China and Russia also have the capability to exercise strategy and employ the elements of national power, each has significant limitations to do so. As a superpower, American economic and military power is sufficient to

Keith D. Dickson is a professor of military studies, Joint Advanced Warfighting School, Joint Forces Staff College, National Defense University. 
influence allies and partners as well as dissuade or deter rivals, and its security and other vital interests cannot be threatened or challenged by any single state or potential combination of states. The United States alone commands enough power to build coalitions and define the circumstances under which a coalition will commit armed force. ${ }^{1}$

The 2017 U.S. National Security Strategy states unequivocally that the United States is "the world's lone superpower," whose "values and influence, underwritten by American power, make the world more free, secure, and prosperous." The United States seeks "a fair and reciprocal international economic system [that] will enhance our security and advance prosperity and peace in the world." The overall strategic goal is "a global order of peace, security, and prosperity" based on "strong, sovereign nations ... grounded in the realization that American principles are a lasting force for good in the world." More significantly, the sole superpower seeks to sustain "favorable balances of power" by summoning "the will and capabilities to compete and prevent unfavorable shifts in the IndoPacific, Europe, and the Middle East." ${ }^{2}$

Despite American efforts to order the international environment in its favor by extending its influence in key regions and supporting global prosperity through economic integration and the spread of free markets, and despite its attempts to create an international system based on both a global and a regional balance of power of states that would support American security as well as reflect American values, the international system over which the United States' currently presides is not operating in conjunction with its interests. The post-Cold War strategic environment has exposed regional and subregional antagonisms and nationalist ambitions. Although war is no longer the means for challenging or changing the international system, as was the case in the previous century, and challenges from state actors have diminished, nonstate and substate actors have filled the gap. States in the present international system have other security concerns and interests, often not in line with the United States, requiring them either to seek to influence the superpower or to act independently. Values and perspectives, as well as the involvement of other actors, have increasingly shaped the superpower's interest in intervention, reinforcing a realization that it can no longer influence or control events at will. ${ }^{3}$

These conditions have shaped the way the United States assesses the postCold War security environment and influences its behavior as a strategic actor. The reaction appears to be an unsettling sense that the superpower is in danger of losing its status. The National Security Strategy reflects this point of view. "As we took our political, economic, and military advantages for granted," the document asserts, "other actors steadily implemented their long-term plans to challenge America and to advance agendas opposed to the United States, our allies, and our partners." The National Security Strategy then points to "the revi- 
sionist powers of China and Russia, the rogue states of Iran and North Korea, and transnational threat organizations, particularly jihadist terrorist groups" as rivals who "compete across political, economic, and military arenas, and use technology and information to accelerate these contests in order to shift regional balances of power in their favor." 4

As expected of a superpower, the United States is consumed by concerns of a potential change in the balance of power, encompassing a strategy that views any state's actions primarily in terms of the pursuit of power and influence contrary to the superpower's interests. Thus, the United States describes Russia in the National Security Strategy as having the ambition to become a great power again, using growing military capabilities "to establish spheres of influence near its borders." China is described as expanding its power at the expense of other states, while also "building the most capable and well-funded military in the world," which clearly implies that the United States perceives an impending threat to its dominance. ${ }^{5}$

Assuming that its national interests and objectives are self-apparent and benign, the strategic leaders of the sole superpower form impressions and attitudes that can lead to oversimplification, while ignoring the conditions that are shaping strategic behavior. This viewpoint can lead to U.S. resistance to alternative perspectives regarding the nature of the strategic environment or resistance to accepting new information. The result is that strategic leaders are unable to assess risk or correctly identify threats. ${ }^{6}$ As its primary strategic document indicates, the United States is still coming to grips with what being a superpower currently means in the post-Cold War strategic environment. The forces of globalization and information technology are fracturing the structure of modern societies and have threatened the legitimacy of the state. More importantly, a new strategic environment based on a postmodern condition has emerged, one in which the United States still has not yet recognized or defined its role. U.S. strategic leaders must learn to recognize this postmodern condition, as it now defines the strategic environment and how this environment shapes the sole superpower's employment of its elements of power in pursuit of its strategic interests.

Postmodernism has become part of a global cultural phenomenon in the post-Cold War period and is the defining condition of contemporary social and intellectual discourse, touching philosophy, history, politics, and theology. The death of Marxism as a viable ideological construct, combined with the failure of modernity to serve as the means of ordering the world, has created a vacuum into which the forces of globalization and information technology have filled and have fractured the structure of modern societies as well as threatened the legitimacy of the state. The entire world of ideas has shifted against traditional modernist claims to knowledge, truth, and reason as an inherent part of human 
nature. In its place is nothing less than a redefinition of both knowledge and of reality itself. In broad, general terms, postmodernism is a form of theorizing about societies. Postmodernism represents a substantial reorganization of how people relate to their environment. It encourages different modalities of meaning, including the transformation of cognitive boundaries and the ways those boundaries are constituted. Postmodernists have established new images of society, language, and humanity, marked by a distrust of science and reason. Culture has been deconstructed as a set of myths produced within a communication system; the power of images and signs stands in for reality. Information is the central commodity that is consumed. ${ }^{7}$

Jean Baudrillard, a French postmodern theorist, whose philosophical and cultural analysis of media, information, and technologies in contemporary life led him to identify the emergence of a different social order. Reality exists in what he described as the simulacra of endlessly repeated signs, symbols, images, or representations that constitute the collective experience. Society functions as a model of itself, creating what Baudrillard calls hyperreality. In turn, the media serves to interpret the hyperreal as real for the consumer. In his essay "The Vanishing Point of Communication," Baudrillard wrote,

we now live in the fantasy of the screen, of the interface, of contiguity, and networks ... the interactivity of men has been turned into an interactivity of screens. We are images one to another, the only destiny of an image being the following image on the screen. ${ }^{8}$

The rise of the media-saturated society of the post-Cold War world has created a new structural grammar whose rules for the production of meaning, composed of a series of signs and images, are based on the logic of desire. Existing models based on the logic of reason no longer apply to the world of simulated reality that pervades the postmodern world. Signs no longer replicate reality. No basic foundation exists on which to engage in a systematic understanding of society. No one can be sure of what is known or what can even be considered correct. As Baudrillard again observed, "every event is virtually without consequences ... o open to all possible interpretations, none of which can fix meaning."

Postmodern theory has discredited two of the core assumptions of modern social theory: subject-centered reason and the stability of meaning. ${ }^{10}$ Postmodernism has offered new theories and conceptions of society, history, and politics, exploring the most basic questions: What passes for knowledge? What is the relationship between power, knowledge, and truth? Knowledge is no longer held to be inherently good, nor is it ever complete; reality is relative, indistinct, indeterminate, and communal. Human intellect alone is not the arbiter 
of truth; truths of the past are no longer valid for the present. Truth, instead, is a social construction, existing only within a community. In the words of French postmodernist Michel Foucault, truth "is the object, under diverse forms, of immense diffusion and consumption . . . it is produced and transmitted under the control, dominant if not exclusive, of a few great apparatuses (university, army, writing, media); lastly, it is the issue of a whole political debate and social confrontation ('ideological' struggle)." 11

The French philosopher Jean-François Lyotard asserted in his highly influential work The Postmodern Condition that to exercise political power, knowledge must be controlled. "Knowledge and power," he wrote, "are simply two sides of the same question: who decides what knowledge is, and who knows what needs to be decided?" Postmodern knowledge is not simply a tool of authorities who attempt to provide a single dominant universal explanation for events; instead, knowledge "refines our sensitivities to differences and reinforces our ability to tolerate the incommensurable." Technological transformations will not allow the nature of knowledge to be unchanged, he argues; instead, it will be mercantilized. "It is conceivable," Lyotard asserted, "that the nation-states will one day fight for control of information, just as they battled in the past for control over territory, and afterwards for control of access to and exploitation of raw materials and cheap labor." 12

Lyotard asserted that, in a world in which reality is destabilized, the grand narrative, used to assert unifying authority and legitimizing power, is suffering: an internal erosion of the legitimacy principle of knowledge. ... Knowledge is no longer the subject . . but in the service of the subject. . . The growth of power, and its self-legitimation ... are now taking the route of . . the operativity of information. ${ }^{13}$

Thus, the superpower is less able to dictate, construct, or sustain a dominant worldview, as the United States and USSR did during the Cold War. Since the end of the Cold War, certainly, the United States has found it increasingly difficult to justify its actions or goals in terms that resonate with either a domestic or global population. Indeed, the nation's current strategic documents reveal an underlying uncertainty that the 150-year-old American idea of self-existence and self-identity are no longer automatically inducible. The postmodern condition that Lyotard identified is that information alone is power: how information — not objective truth or knowledge - is used and whose interests it serves is the emerging reality of the strategic environment.

The U.S. population is rapidly drifting toward becoming a postmodern society - a culture of image and novelty, marked by an "endless supply of catchy phrases, slightly bizarre images, and stylish ideas" that break the link between 
truth and politics. ${ }^{14}$ American strategy analyst Steven Metz has addressed the larger ramifications for strategic leaders. He notes that in an emerging era of "post-truth" (certainly a clear manifestation of the postmodern condition), there is the capability of combining words and images to create a manufactured world that replaces everyday reality, making it significantly more difficult for the public in the United States and in other countries to distinguish lies, halftruths, gossip, fantasy, code words, and phrases from reality. He warns this will destroy the traditional American notion of strategic communications, which is based on a basic trust in analysis to establish objective truth and the belief that this truth will ultimately win out. ${ }^{15}$

Russia has been the first country to adopt a strategy that combines realism with a thorough understanding of the postmodern condition. The appearance of armed, masked men in Crimea and eastern Ukraine; the downing of a commercial airliner; the use of nerve agents against Russian citizens abroad; and the attempted manipulation of public opinion to sway elections all exploit postmodern society's lack of faith in truth; its notions of fungible reality; and its focus on multiple, equally valid narratives in a heavily layered simulacrum of images, words, and meanings. While not making the postmodern argument explicitly, Russia nonetheless confidently conveys a postmodernist meaning in its defense. In Russia, information is power. Satellite television and radio are integrated with the internet, social media, and contributions of professional and amateur journalists to manufacture information. Russia exploits national media outlets, as well as government and defense sources, shamelessly to present a version of postmodern truth intended at once to reinforce domestic support while simultaneously confounding international public opinion. One of Russia's most influential multimedia news providers is RT, which broadcasts in dozens of languages throughout Europe, and is especially popular as an online news source. Along with Sputnik, a news agency, these media outlets provide a remarkable combination of infotainment and disinformation. While reports often have elements of truth, these elements are skillfully blended with manufactured information and manufactured sources. ${ }^{16}$ It is the perfect simulacra Jean Baudrillard would instantly recognize.

When confronted with evidence, the Kremlin blithely dismisses any charges or accusations, denying in essence the existence of objective truth, while also indirectly accepting yet rejecting indictments as an elitist narrative. In response, leaders and populations of the West have been thoroughly befuddled and paralyzed, claiming that Russia has embarked on a new form of warfare, when in fact, the postmodern society, when confronted with its own arguments and presented with its own rationale, cannot respond and its outrage quickly fades to mere concomitance.

Russian society itself has adopted the postmodern worldview, heightened 
by a sense of isolation and insecurity, creating many layers of alternate realities in troll farms and absorbing and reflecting a state-sanctioned, media-driven narrative of Western hostility. Russia essentially discounts the West's claim to rules-based order as a modernist conceit that is nothing more than a narrative of power intended only to benefit the few at the expense of the many.

War itself, as Mary Kaldor and Herfried Münkler have argued, has changed. Arguably it has become a new kind of war because war is now fought by postmodern societies and has little resemblance to war fought by states for political ends. The state still exists, and therefore, the Clausewitzian trinity of the people (society), the government (politics), and the military may also still exist-but only symbolically. The military still functions as a traditional modernist institution, but it is largely divorced from the people. Politics is less concerned with state interests than the cosmopolitan demands of human security. Instead, what has replaced this trinity is an "intricate mix of physiological, psychological and sociological factors" related to the people and information that define the postmodern condition. ${ }^{17}$

New wars today are, in actuality, varying levels of disordering violence and instability in areas of weak or nonexistent government control involving exceptionally complex sectarian, ideological, tribal, and ethnic interactions of armed groups and warlords fed by the involvement of regional and international actors. The violence is postmodern: there are no rules, norms, or limitations. Violence is an end in itself rather than serving a specific strategic political end. Münkler defines new war as the "gun-fed rise of socially excluded layers, who take revenge for past humiliations by killing those with a regular livelihood or perhaps even modest prosperity." 18

Since the end of the Cold War, the United States and NATO have attempted to subordinate the primordial violence, anarchy, and enmity they have encountered in Africa, the Middle East, and Afghanistan to a rational policy that conforms to the Clausewitzian dictum of war:

it is clear that war should never be thought of as something autonomous but always as an instrument of policy. . . . War is simply a continuation of political intercourse, with the addition of other means. ... War cannot be divorced from political life. ${ }^{19}$

The subordination of war to politics is the heart of modern concept of sovereignty, and it is the guiding principle of the superpower.

In the postmodern strategic environment, an important question to ask is if this Clausewitzian relationship is still immutable. A multitude of nonstate and substate actors now possess the interests and motivations that drive the decision for war that were once solely the purview of the state. They are fueled by access 
to both legal and illegal globalized networks for supplies and sustainment, serving their own interests. ${ }^{20}$ The byproduct of this disordering violence is material and ideological conflict and humanitarian disaster.

The aims and objectives of these nonstate and substate actors relating to power relations could be understood as politics - the interaction of thinking and acting in an effort to exercise power and gain dominance against resistance. These power relations are often constituted as an ongoing struggle and contest of contending forces employing violence, coercion, and force and are understood as having tactical and strategic aspects. ${ }^{21}$

If politics in a postmodern context refers to calculations and practices based on interests of power that touch issues of identity, culture, and history, the Clausewitzian relationship between war and politics is inverted. Michel Foucault, in his analysis of power in terms of conflict, confrontation, and war, interpreted political struggles, clashes over or with power, or modifications of relations of force in a political system as a continuation of war. Thus, politics, practiced as conflict and confrontation, has become the continuation of war by other means. ${ }^{22}$ It is now possible to provide a general summary of the strategic landscape fabricated by postmodern thought.

The validity of large-scale political movements or ideologies is rejected in postmodern thought. Nationalism is suspect, giving way to localism, characterized by multiple centers of power and activity that are controlled by self-contained social groups, shaped by a global communication network, each with a distinct sense of identity, defined through culture, ethnicity, religion, ideology, and values and beliefs. Loyalty is given to the group, rather than to any central authority. Capable of interconnecting with a global audience almost at will, these groups exist in the perpetual present in online chat rooms, discussion forums, and comments sections on websites, where a recipient who belongs to a group trades information from another group perceived to be credible. In this constant trading and perpetuation of information, Lyotard's postmodern vision has become a popular cultural phenomenon, employing a common language and applying collective philosophical concepts. ${ }^{23}$

Nearly everyone in postmodern society has an online persona (or personas), who functions in an alternative reality and can influence, or be influenced by (directly or indirectly), other contacts online. The Islamic State of Iraq and Syria (ISIS) is a postmodern phenomenon, exploiting the simulacra of postmodern society to recruit young men and women to engage in a real-life version of the first-person shooter video games that they have made their personal version of reality.

In the postmodern strategic condition, culture and society both shape and create beliefs and values. People exist in a simulacrum of multilayered, continually changing background of social and psychological influences, composed 
of images and signs that both shape reality and how it is perceived and understood. Media interprets the hyperreal as real for the consumer and dictates what is known. Because language is a form of privilege and authority, it is considered incapable of describing external realities, and therefore it is arbitrary and changeable. New realities are created through language, which offer continually changing meanings in relation to different times, or different conditions, or both.

The idea of extant truth is replaced by the idea that truth is constructed by people themselves, relative to environmental or social factors. Perspective is a matter of culture and environment and not gained by elitist metanarrativesdefined as a particular worldview or ideology often reflected through a broad historical portrait intended to reflect reality. These metanarratives are inherently oppressive and deny marginalized groups in society a voice. All claims to authority or truth are disguised as claims to power. Faith in reason as a means of finding truth is questionable. Truth and reason themselves are outmoded concepts-reflecting nothing more than an accepted belief. ${ }^{24}$

The ramifications of this new strategic landscape are that the postmodern sociocultural environment functions in direct opposition to a national strategic community with a strategic culture that depends upon historical patterns and customarily accepted traditions, values, and symbols to understand the environment and that approaches problems that involve either the threat of force or the actual use of force. Open markets and social identities "without universally acknowledged moral principles, international law norms, and accepted political practices" have created new power structures outside of the state. ${ }^{25}$

This postmodern challenge to the superpower's conceptualization of the relationship between war, conflict, and peace should lead to a reassessment of how the United States can influence and order the international system. Perhaps seeking to examine how strategies of power are influencing the strategic environment in terms of how threats are defined, understood, and resisted could be understood as war subordinated to politics. ${ }^{26}$ Foucault provides a key insight for the superpower. He observed that power exercises, circulates, and forms networks and "mechanisms of power cannot function unless knowledge, or rather knowledge apparatuses, are formed, organized, and put into circulation." ${ }^{27}$ General Sir Rupert Smith, recognizing the postmodern condition, calls the new phenomenon "war amongst the people," and he states that "information, not firepower, is the currency upon which it is run." 28

When diplomats, strategists, and military professionals attempt to define and frame complex international problems, formulate strategy to support policy to achieve national security goals, or make decisions about employing the elements of national power in pursuit of interests, they begin with a common approach and a basic set of assumptions. Yet, each one of these assumptions is invalidated 
by the postmodern theories and conceptions of society, history, and politics.

As the sole superpower, the United States is defined by its sovereignty, territoriality, recognizable national identity, superior technology, military capability, and economic power. The postmodern strategic environment, however, places little importance on those defining elements of the nation-state as a strategic actor and indirectly imposes distinct limits on how national power is used. The traditional interests of states that serve as the source of competition and conflict hold little regard to a globalized, postmodern society where multiple identities and individualism are more important than appeals to a citizen's loyalty and obligations to the state. The small, professional military force is disassociated from the population and functions nearly invisibly, causing increasing divisions in the civil-military relationship. ${ }^{29}$

By failing to understand the true structure of the post-Cold War strategic environment defined by the postmodern condition, the superpower can be strategically confounded. Strategies, grand or otherwise, are difficult, if not impossible, to devise and implement. The large-scale employment of military force becomes increasingly questionable to a global population.

Faced with such a daunting reality, how is the strategic leader to approach the maintenance of an international order that supports American security and a peaceful environment while also encouraging the protection of democracy and human rights? If postmodernism is becoming the new geostrategic frame, it is necessary to understand its forms and functions. Our very understanding of the relationship between policy and strategy is being challenged. Can any view of policy and strategy be valid? How can statecraft be practiced? How are the conditions that define peace and war to be understood? The postmodernists themselves may provide an answer. "The problem," as Michel Foucault wrote, "is at once to distinguish among events, to differentiate the networks and levels to which they belong, and to reconstitute the lines along which they are connected and engender one another." ${ }^{30}$ Thus, it is essential to structure the strategic design process in such a way that identifies networks of power and how knowledge functions within those networks, while also uncovering the multiple pathways that knowledge and power interconnect. The superpower can still employ its own significant network of power and knowledge to shape and influence events that favor its interests and goals, but it must recognize that this network of power and knowledge must now be employed in a postmodern context according to a different framework.

Policy is a function of strategy; strategy is a process of reasoning that implements a policy decision. Strategy applies the best methods available within the confines of the strategic environment to achieve the desired objectives. Distinguishing events, differentiating networks and levels associated with events, and reconstituting lines of connection is, in essence, a process of logic and reason, 
which are the vital skills of the strategist. The strategist and strategic leader must be trenchant and perceptive observers of the postmodern condition in global society and define its essential nature in order to use a structured process based on logic, reason, and facts to allow strategy to function effectively to serve the superpower's interests.

The postmodern condition promotes diversity and relativism, along with multiple realities, each having its own unique discourse, and its essential characteristic is "emotivism," in which "judgments made by people are only expressions of feelings and personal preferences, and no longer carry any morally essential evidence." 31 Thus, the salient importance of political psychology and appreciating the significant interaction between actors and observers in the postmodern strategic environment is central to sustaining the superpower's role, whose primary task is maintaining international stability, rather than enforcing it. This approach requires a level of intellectual discipline and a careful assessment of where, when, and how American power is employed and to what effect it has in shaping what is known. ${ }^{32}$

Although the postmodern strategic environment imposes the same limitations on all state actors, the superpower alone has the ability to use its power to create the image and idea that it is providing security and stability, which may actually be more effective than traditional efforts to use the elements of national power to impose a particular desired set of conditions on the strategic environment. Rather than basing strategy on a belief that the United States alone must maintain security and stability, the potentially powerful strategic effects of using perception to shape behavior in the postmodern environment should not be ignored. Strategy's character must continually evolve with changes in society. For any strategy to be employed successfully, an interlocking process of reasoning will be necessary to identify the labyrinthine modes of thought in postmodern society for the strategist to link strategic effect to the goals of policy.

In the face of this consumer culture caught up in random change and saturated with information, strategy remains essential to maintain peace within an international order that adheres to humane, moral values. It provides a coherent outline that bridges the gap between current and desired future conditions. Government policy - the need to bring together all elements of power for the advancement of long-term interests-selects the strategic objectives and shapes the strategic approach; yet, it must be flexible enough to adapt to changes in technology, society, and political ideas. Strategists and military leaders must take on a culturalist perspective to function within the postmodern environment, examining the postmodern condition analytically to understand the beliefs and attitudes that reveal behavior and perceptions of realities. ${ }^{33}$

This culturalist approach does not mean that the postmodern condition is to be accepted as a valid way of ordering or understanding the world. Ironically, 
it should be just the opposite; the culturalist approach uses all of the traditional modernist intellectual skills that the postmodernists reject. Within this culturalist approach and analysis, strategists, diplomats, and military professionals must adhere to the verities of their professional development, education, and training, especially the essential idea of empirical research: social facts constitute an independently existing moral order. Civil society has a structure grounded in both an objective morality and an objective history that serve to explain humanity, progress, and power.

Rationality is manifested in the summation of theories, beliefs, principles, and facts that are used to understand the world. These basic principles for the strategist can be summarized as follows:

1. The strategist must have the ability to know and apprehend the external world through an objective and dispassionate examination of facts, while considering biases and assumptions.

2. Certain beliefs exist.

3. A confidence in human reason and the recognition of a proper method to acquire knowledge exists.

4. Objective reality exists; genuine knowledge is possible; objective truth is indispensable.

5. Language is essential to capture and mirror the real world accurately by putting thoughts into meaning for understanding; the full meaning of words is present in language.

Out of these principles come the following essential and enduring factors for the formulation and implementation of strategy: policy is a function of strategy; strategy is a process of reasoning that implements a policy decision. Strategy applies the best methods available within the confines of the strategic environment to achieve the desired objectives. For strategy to be employed successfully in the postmodern environment, an interlocking process of reasoning will be necessary to identify the complex and divergent modes of thought in postmodern society.

This means that a realist strategy as outlined in the current National Security Strategy can be implemented, but the goals and interests of that strategy must be pursued in an entirely new context. For the perceptive strategist, the inherent contradictions, skepticism, intellectual despair, rootlessness, and frustrations of postmodern society open innumerable opportunities for strategic initiative. The goal is to locate and identify the major forces and networks within postmodern society that can be exploited, particularly between the elite and the popular masses. Postmodern society is characterized by psychological instability-a fragmentation of will and intellect. As the sole superpower, the U.S. goal for policy and strategy in the twenty-first century will be to create a situation for 
which the postmodern condition has no answer in response outside of pure nihilism.

The following is a proposed outline of action for the superpower in formulating and implementing strategy in the postmodern strategic environment: ${ }^{34}$

1. Understand history - use the tools of historical inquiry-and the assessment of facts and logical conclusions derived from objective analysis to provide a historical perspective and assessment to explain contemporary events. Identify the causes of stability and instability and their influence from the postmodern perspective.

2. Using an objective, factual approach to characterize the present postmodern strategic environment and define the policy-strategy linkages (the policy object outlined in terms of desired strategic gain balanced by risk). Define how these linkages are going to be perceived within a postmodern construct.

3. Identify key strategic tendencies that are both helping and hindering and are shaping the choices of an actor (state or nonstate).

4. Identify and prioritize the threats to your interests and vulnerabilities to those threats.

5. Define the desired ends by identifying the desired future environment, with an understanding that it must conform to some postmodern perception of reality and explained within a frame that is at least compatible with postmodern thought.

6. Choose the means to achieve ends with recognition of ultimate consequences-define the change that will occur to the existing order and what will be necessary to adapt to those changes, recognizing that adjustments will have to be made continually-almost day-to-day, to conform to the postmodern strategic environment.

7. Assess the resources available during the time being considered. Can they be employed effectively in a media-saturated environment?

8. Define the various strategic lines of effort. These can be elements of national power at varying degrees of intensity, but far more likely will involve abstract psychological activities as well as a combination of limited overt violent actions to compel desired outcomes, or violent or nonviolent covert or clandestine actions. These will cause a set of events - intended to influence a friendly, enemy, neutral, as well as a domestic audience - to occur that work toward the desired end.

9. Seize and sustain the initiative in the argument-create and shape what is known within the simulacra. Create multilayered forms, signs, ideas, and images that are absorbed and accepted within the various social groups. 
Strategists, diplomats, and military professionals must maintain an adherence to the modernist construct of reason and the validity of objective truth. However, they must be at the same time trenchant and perceptive observers of the postmodern condition in a global society to be able to define its essential nature in order to use a structured process based on logic, reason, and facts to allow strategy to function effectively for the United States, as the sole superpower, to preserve a structure of peace and security in the face of the daunting challenges to the post-Cold War world order.

\section{Notes}

1. See Robert Jervis, "Unipolarity: A Structural Perspective," World Politics 61, no. 1 (January 2009): 191, 195, https://doi.org/10.1017/S0043887109000070; and Christopher J. Fettweis, Psychology of a Superpower: Security and Dominance in U.S. Foreign Policy (New York: Columbia University Press, 2018), 75-76. The term superpower implies a state's overwhelming military, economic, and political-diplomatic dominance "that can impose its preferences by eliciting, either through coercion or consent, the cooperation of other states and actors." Roger E. Kanet, "American Strategy for Global Order," in From Superpower to Besieged Global Power: Restoring World Order after the Failure of the Bush Doctrine, ed. Edward A. Kolodziej and Roger E. Kanet (Athens: University of Georgia Press, 2008), 338.

2. Office of the President, The National Security Strategy of the United States of America, December 2017 (Washington, DC: Government Printing Office, 2017), 1, 18, 41, 45, 55.

3. Hal Brands, American Grand Strategy in the Age of Trump (Washington, DC: Brookings Institution Press, 2018), 3-4; and Jervis, "Unipolarity," 195, 208.

4. Office of the President, The National Security Strategy, 2, 25-26.

5. Office of the President, The National Security Strategy, 25.

6. Fettweis, Psychology of a Superpower, 80, 83, 85, 92-95.

7. Jorge Arditi, "Out of the Maze?: Twists and Turns of Postmodern Thinking," Contemporary Sociology 22, no. 1 (January 1993): 23, https://doi.org/10.2307/2074968; and William Bogard, "Closing Down the Social: Baudrillard's Challenge to Contemporary Sociology," Sociological Theory 8, no. 1 (Spring 1990): 1-15, https://doi.org /10.2307/202191.

8. David B. Clarke et al., eds., Jean Baudrillard: Fatal Theories (London: Routledge, 2009), 20.

9. Jean Baudrillard, Selected Writings (Boston, MA: Polity Press, 1988), 193.

10. Subject-centered reason assumes an objective world of universal, intrinsic truth, in which the foundations of knowledge are definable and in which language plays a fundamental role.

11. Douglas Kellner, "Theorizing the Present Moment: Debates between Modern and Postmodern Theory," Theory and Society 28, no. 4 (August 1999): 646, https://doi.org /10.1023/A:100704301; Stanley J. Grenz, A Primer on Postmodernism (Grand Rapids, MI: William B. Eerdmans Publishing, 1996), 7; and Michel Foucault, "Truth and Power," in The Foucault Reader, ed. Paul Rabino (New York, Pantheon Books, 1984), 73.

12. Jean-François Lyotard, The Postmodern Condition: A Report on Knowledge, vol. 10, Theory and History of Literature, trans. Geoff Bennington and Brian Massumi (Minneapolis: University of Minnesota Press, 1997), xxv, 4-5, 8-9.

13. Lyotard, The Postmodern Condition, 36, 38-39, 47.

14. Wolin, "Democracy in the Discourse of Postmodernism," 313-14.

15. Steven Metz, "Strategic Insights: Revolutionary Change Is Coming to Strategic Leadership," Strategic Studies Institute, 19 December 2017. 
16. Christopher Paul and Miriam Matthews, The Russian "Firehose of Falsehood" Propaganda Model: Why It Might Work and Options to Counter It (Santa Monica, CA: Rand), 2-3, 5, https://doi.org/10.7249/PE198.

17. BGen Edwin R. Micewski, Austrian Army, "Education of (Military) Leadership in a Postmodern World," Connections 3, no. 1 (March 2004): 73, https://doi.org/10.11610 /Connections.03.1.06.

18. Herfried Münkler, The New Wars, trans. Patrick Camiller (Malden, MA: Polity Press, 2005), 79.

19. Carl von Clausewitz, On War, ed. and trans. Michael Howard and Peter Paret (Princeton, NJ: Princeton University Press, 1976), 88, 605.

20. See, for example, Mary Kaldor, New and Old Wars, third ed. (Stanford, CA: Stanford University Press, 2012), 161-75.

21. Jason Edwards, "Foucault and the Continuation of War," in The Metamorphosis of War, ed. Avery Plew (Amsterdam: Rodopi, 2012), 26, 35.

22. "Politics, in other words, sanctions and reproduces the disequilibrium of forces manifested in war." Michel Foucault, Society Must Be Defended: Lectures at the Collège de France, 1975-76, ed. Mario Bertani and Alesandro Fontana, trans. David Macey (New York: Picador, 2003), 15-16; Andrew W. Neal, "Cutting Off the King's Head: Foucault's Society Must Be Defended and the Problem of Sovereignty," Alternatives: Global, Local, Political 29, no. 4 (October 2004): 375, 383, https://doi.org/10 .1177/030437540402900401; and see also Roger Deacon, "Clausewitz and Foucault: War and Power," Scientia Militaria: South African Journal of Military Studies 31, no. 1 (2003), 41, https://doi.org/10.5787/31-1-142. Deacon quotes Michel Foucault's observation that " '[e]very power relationship implies, at least in potential, a strategy of struggle' or confrontation." These power relationships are continuously acting and reacting strategically and tactically, based on existing circumstances and conditions and operating in a realm of uncertainty.

23. Grenz, A Primer on Postmodernism, 35; and Sheldon S. Wolin, "Democracy in the Discourse of Postmodernism," in Fugitive Democracy and Other Essays, ed. Nicholas Xenon (Princeton, NJ: Princeton University Press, 2016), 301-4, 308-9, 311.

24. See Jean Baudrillard, "The Ecstasy of Communication," in The Anti-Aesthetic: Essays on Postmodern Culture, ed. Hal Foster (Port Townsend, WA: Bay Press, 1983), 133-37; Pauline Marie Roseneau, Post-Modernism and the Social Sciences: Insights, Inroads, and Intrusions (Princeton, NJ: Princeton University Press, 1992), 3, 53-55, 119, 142, 147; and Grenz, A Primer on Postmodernism, 7, 12, 35, 128, 149.

25. "The work of sociocultural theory is to explain how individual mental functioning is related to cultural, institutional, and historical context; hence, the focus of the sociocultural perspective is on the roles that participation in social interactions and culturally organized activities play in influencing psychological development." Sarah Scott and Annemarie Palincsar, "Sociocultural Theory," education.com, accessed 18 June 2018; Edward A. Kolodziej, "From Superpower to Besieged Global Power," in From Superpower to Besieged Global Power, 329, 334; and Brands, American Grand Strategy, 21.

26. Edwards, "Foucault and the Continuation of War," 37-38.

27. Foucault, Society Must Be Defended, 30, 33-34.

28. Gen Rupert Smith, The Utility of Force: The Art of War in the Modern World (New York: Alfred A. Knopf, 2007), 377.

29. Barry Buzan and Gerald Siegel, "The Rise of 'Lite' Powers: A Strategy for the Postmodern State," World Policy Journal 13, no. 3 (Fall 1996): 3.

30. Foucault, "Truth and Power," 57.

31. Micewski, "Education of (Military) Leadership in a Postmodern World," 70. Micewski attributes "emotivism" to Alasdair MacIntyre, the British moral philosopher. See Alasdair MacIntyre, After Virtue: A Study in Moral Theory, third ed. (Notre Dame, IN: University of Notre Dame Press, 2007).

32. Fettweis, Psychology of a Superpower, 25, 34, 36, 40. 
33. Hew Strachan, "Strategy and Contingency," International Affairs 87, no. 6 (November 2011): 1282, 1296, https://doi.org/10.1111/j.1468-2346.2011.01036.x; Colin S. Gray, "In Praise of Strategy," Review of International Studies 29, no. 2 (April 2003): 292, https://doi.org/10.1017/S0260210503002857; and Harry R. Yarger, Strategic Theory for the 21st Century: The Little Book for Big Strategy (Carlisle, PA: Strategic Studies Institute, U.S. Army War College, 2006), 5.

34. This outline reflects many of the concepts of strategy found in André Beaufré, Strategy of Action, trans. R. H. Barry (London: Faber and Faber, 1967), 13, 15, 132. 


\title{
Cyberspace as a Domain of Operations What Is NATO's Vision and Strategy?
}

\author{
Jamie Shea, PhD
}

\begin{abstract}
This article explores the ramifications of the North Atlantic Treaty Organization's (NATO) decision in 2014 to declare cyber as a domain of operations. It outlines the cyber threat landscape that has given rise to this initiative and the doctrinal and organizational steps NATO has taken to implement this concept within its military planning and structures. Finally, the article analyzes how NATO's greater access to cybercapabilities can enhance its overall deterrence and defense.
\end{abstract}

Keywords: cyber threats, cybercapabilities, domain of operations, deterrence, defense

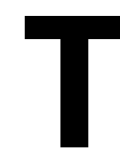

oday, the 29 member states of NATO face a more diverse, complex, and rapidly evolving security environment than at any time since the end of the Cold War-and arguably since the creation of the alliance itself 70 years ago. In particular, the growing dependence on cyberspace and the need to exploit it to ensure the success of military operations, presents an all-embracing challenge which, if mishandled, could inflict lasting damage on our societies and institutions. The secretary general of NATO, Jens Stoltenberg, has affirmed that a cyberattack could be as devastating as a conventional attack, and as everything becomes more technology dependent, almost anything can be hacked. ${ }^{1}$ Back in 2014, at NATO's summit in Wales, the heads of state and government declared that cyberdefense is a core part of the alliance's mission

Dr. Jamie Shea is deputy assistant secretary general for emerging security challenges at NATO. The views in this article are entirely those of the author alone. They should not be construed as representing an official position of NATO but are contributed in a purely personal capacity.

MCU Journal vol. 9, no. 2 
of collective defense. ${ }^{2}$ Therefore, in the event of a cyberattack above a certain threshold of damage and demonstrated aggressive intention, NATO will consider it equivalent to an armed attack and give rise to the same full spectrum of military response as an attack in the shape of tanks, missiles, and artillery. The recent U.S. nuclear doctrine makes this linkage implicit by connecting even the most extreme form of military response to strategic nonnuclear attacks, which could arguably encompass a potentially devastating cyberattack. ${ }^{3}$

In 2016, at NATO's summit in Warsaw, Poland, the leaders went a step further and recognized cyberspace as a domain of military operations in which NATO has to be able to operate, and ultimately prevail, as it does in the air, on land, and at sea, especially against peer competitors or adversaries who will possess many of the same technologies and operational savoir faire. As the alliance derives nearly all of its military capabilities from national programs, the Warsaw Summit also launched a Cyber Defence Pledge to commit all 29 allies to invest more resources in their national networks and infrastructures, particularly those on which the two NATO strategic commands (Allied Command Operations and Allied Command Transformation) depend on for their communications, command and control, and operations. ${ }^{4}$ Subsequently, NATO defense ministers endorsed a road map to implement cyberspace as a domain of operations. They called for a high-level military vision and strategy that could guide doctrine and capability development to enhance the alliance's cyberdefenses and produce, as required, bespoke cybereffects to achieve specific tactical or strategic objectives. This article explores the ramifications of this endeavor as the major powers of the twenty-first century all seek to leverage the cyberspace domain to achieve their military, political, diplomatic, and economic objectives.

Analyses of the cyberthreat usually begin with a barrage of statistics on the latest piece of malware, the number of computers or routers affected in so many countries, or the exploits of the hottest hacking syndicate on the scene. It is hard to avoid this approach, as indeed no month goes by without organizations such as NATO reporting on a wide range of threats, potential vulnerabilities in certain NATO systems, and attack vectors. For instance, in the run-up to the July 2018 NATO Summit in Brussels, we were tracking the VPNFilter threat to 500,000 routers affected in 54 countries, including NATO nations. This malware could be used to monitor internet communications to collect intelligence and had the potential to be used for destructive purposes or as a staging point for future attacks. ${ }^{5}$ We also were analyzing the impact and methodology of dozens of denial of service attacks (DoS attacks) against the public-facing NATO web services. Because attributing a DoS attack can be very difficult as it can be launched from any computer or internet-connected device or from several at once, NATO has been sharing evidence and working with the law-enforcement community to help identify the sources. At the same time, our Cyber Threat 
Assessment Cell has continued to track the activities of by now well-known advanced persistent threat groups, such as Fancy Bear-the group purportedly responsible for the malware Sofacy - to identify their evolving tactics, techniques, and procedures. Knowing their tradecraft better helps to anticipate a switch from one type of target to another. Often a main advanced persistent threat (APT) group will spawn subgroups that operate with different levels of sophistication and targets but still share the same command and control infrastructure. Finally, we were reporting on the endless wave of social engineering and spear phishing attacks against NATO military and civilian personnel, using increasingly sophisticated amalgams of public and publicly disclosed classified information. This level of sophistication makes opening an attachment or clicking on a link look as routine and as authentic as possible.

Most military leaders or industry executives reading a typical NATO incident report would immediately recognize these cyberchallenges or recall similar experiences. Indeed, threat intelligence, rapid sharing of information between government and industry, and staff training on the essentials of recognizing cyberthreats continue to be the key to effective cybersecurity. They also are enduring problems for nearly all organizations and companies, making it a requirement for all organizations to have constant staff awareness of cyberthreats. There also are related difficult decisions about the balancing between sharing data and restricting its access according to the need to know. Tracking the technology is also important because innovation in the cyberdomain, driven by speed, convenience, and connectivity tends to engender far more new security headaches than security solutions. It is essential to continue to track emerging technologies, because this issue will remain true for the foreseeable future. The internet of things, in which entire communications or operating networks can be brought down by simple design flaws in children's toys, refrigerators, or television consoles, is a case in point. ${ }^{6}$ Yet, an understanding of technology or of vulnerabilities to individual systems is not in itself adequate to develop a military vision and doctrine for cyberspace. What is key is an understanding of what is unique to cyberspace versus the traditional domains of land, sea, and air. How is cyberspace changing our long-held beliefs about great power competition and conflict? Is it merely an enhancement of traditional strategies or a game changer forcing us to rethink our notions of deterrence, defense, and resilience? Has cyberspace shifted the center of gravity of conflict from land, borders, and strategic economic assets to society and populations at large? If NATO has decided to implement cyberspace as a domain of operations, it is because it has recognized the importance of these strategic shifts, but it also views the debate around the domain issue as a means to further explore their significance.

Certainly, cyberspace has led to a world in which anyone, anywhere can attack almost anything at any time. The barrier to entry is low and malicious 
actors can attain the skills and modest resources to engage in disruptive cyberspace activities. Though foiled at the last minute, a 16-year old teenager in Bradford, United Kingdom, was able to plan, finance, and recruit the operatives to carry out a terrorist attack against the Australia Day military parade in Melbourne, without leaving his bedroom 12,000 miles away. ${ }^{7}$ Achieving a strategic impact, however, involves more than the tenacity of a single individual and requires some form of group and organization. Potential adversaries can leverage advanced skills and resources to orchestrate cyberspace effects in tandem with traditional military and diplomatic actions. A myriad of proxies, often organized criminal groups, are available for hire, either by states or malicious individuals, to carry out these attacks. Sometimes they receive intelligence and technical help from states, and in other cases they pass it on to states in exchange for protection and sponsorship. The leak of information on zero day exploits from the National Security Agency in the United States that led to the WannaCry attacks started by North Korea is one such example, showing how state intelligence services and hacking syndicates can cooperate in reengineering malware. ${ }^{8}$ Another is the way in which states can discreetly place compromising information into the public domain, which is derived from sophisticated hacking operations. This was the case in the material allegedly fed to WikiLeaks, DCLeaks, and individual hacktivists such as Guccifer 2.0 during the 2016 U.S. elections.

The ability to remotely manipulate or disrupt activities through cyberspace increases the opportunity to rapidly generate effects, while maintaining deniability and complicating attribution. Threats in cyberspace often operate below traditional levels of crisis or conflict, thereby placing the burdens and risks of escalation on the defender who has to decide whether the costs incurred justify the risks of retaliation and a tit for tat exchange of hostilities. Resorting to conflict in cyberspace implies less violence and smaller levels of destruction; however, it also means more frequent and invasive disruptive activity. To do nothing and simply absorb the attack, with the associated costs of compromised information, however, still results in an expensive recovery or an open invitation to the aggressor to continue with impunity, which is not a credible option either. An effective internet is not only one that is open and as universal as possible but also one that is trusted and reasonably secure. Democratic states should establish that attacks emanating from cyberspace can carry equal weight (and consequences) as attacks that originate in the real world. That said, determining when the threshold of an armed attack has been crossed is not easy, as cybereffects do not cause large explosions, visible physical damage (in most cases), or loss of life, even on a small scale, at least up to now. Thus, the emotional surge of outrage or international solidarity, associated with the terrorist attacks on 11 September 2001 against New York City and Washington, DC, may well be lacking. By the 
time convincing attribution has been established, months may have passed and the political will to retaliate or to rally the international community into action may have subsided. These considerations present unique challenges for NATO to organize timely military readiness and response options that must be both usable in the real world and effective if used. Those responses also may lie outside cyberspace and even the military remit and involve other sectors of society or government; responses are more difficult when several different decisions need to be reconciled. For example, economic sanctions or bans on commercial deals may impact other countries and businesses, and these countries will need to be convinced to take action. U.S. measures against Chinese or Russian tech companies, adopted for reasons of supply-chain security (e.g., ZTE or Kaspersky), are a case in point when these companies have developed their activities well beyond the government sector, and the disruption caused by ceasing to use their services can be severe. ${ }^{?}$

Cyberspace also differs from other domains in that it is a constantly evolving man-made construct with few limitations on where effects can be created. This complicates the task of maintaining global awareness from the strategic to the tactical level. Moreover, the reusability of the means to create an effect in or through cyberspace-it is easier and massively cheaper to design a new piece of malware than a new missile-compensates for the risk of these means being captured and reused against third parties, or even against the originator. These aspects present new challenges regarding the planning and conduct of military missions. For cyber is not only a domain in its own right in which decisive, war-winning blows can be inflicted on an adversary at any time, but it also determines the outcome of traditional conflicts as modern tanks, missiles, fighter aircraft, and drones are increasingly linked to the internet. They are becoming less individual platforms and more part of increasingly complex, networked electronic ecosystems. In this way, cyberspace may gradually become less of a separate, fifth domain of conflict, but instead it may become the only domain as data management and electronic connectivity determine the effectiveness of every connected, man-made physical object.

Finally, unlike the other domains, NATO as both a military alliance and an international organization owns, operates, and must, as a priority, protect its own segment of cyberspace (i.e., the NATO enterprise bringing together NATO headquarters, the military command structure, and various agencies and training academies with more than 60 key sites to be protected 24/7). To defend itself, NATO relies on a mix of NATO collective and national capabilities, as well as on the critical infrastructures supporting them. This presents unique organizational and command and control challenges given the much larger number of civilian actors and capabilities that must be coordinated and made interoperable across the spectrum. These challenges range from situation- 
al awareness, detection, response, mitigation, and recovery to specific cyberoperations. It also changes the traditional paradigm where NATO has most of the assets required for these tasks in-house (in the form of military units and capabilities) and under its direct control to a situation where many of the critical assets come from outside NATO and from completely different areas of government or the private sector. Identifying what you need from others and persuading them to provide it to you when you need it makes effective cyberdefense as much a diplomatic and political as a more narrowly technological and organizational challenge.

Arrangements have to be found that incentivize organizations and companies to be willing to exchange information because there is a mutual benefit, and the risks of compromise or of damage to reputation can be contained. To overcome these obstacles, NATO has developed a malware information sharing platform (MISP), which enables certain companies as well as the European Union (EU) to exchange information with NATO in a way that provides the necessary granularity to be actionable while not threatening the confidentiality of sources. It thus combines convenience and speed with security. At the same time, cyberdefense becomes a new ecosystem in which everything must work for anything to work. It is based not only on technology but also on people and their skill sets, processes, and overall organization. Getting all four factors right and working together optimally requires rigorous systems analysis and experimentation. At a given time, spending U.S. \$1 million on staff training or an overhaul of processes can bring greater benefit than the usual technology upgrade. Understanding the nexus between technology and organization has to some extent always been the way to success in warfare. Think, for instance, of France's defeat by Germany in May/June 1940. This was not caused by France's inferiority in tank or troop numbers. Indeed, French tanks like the Char B1 tank were the equivalent of the Panzers and Leopards of the Wehrmacht. It was more that the German commanders had spent time and effort figuring out the best combination of troops, armor, tactics, and organization through rigorous systems analysis and field training and exercises and the French had not-at least not to the same extent. In the cyber age, because of the more rapid evolution of technology, continuous experimentations of the interrelationship of knowledge, processes, and individual skill sets is fundamental to stay ahead of the curve.

Accordingly, a military vision and strategy for cyberspace rests on two guiding principles. First, that effective defense depends on a sustained level of readiness and the ability to generate effects rapidly ahead of any crisis or conflict. And second, the complicated coordination of cyberspace operations, where many different actors need to operate smoothly, requires a centralized construct. This is because the advent of cyberspace not only complicates the 
conduct of conventional conflict by creating doubt in the mind of the commander regarding the reliability of their weapons systems, communications, and data, but it also opens up whole new vistas of warfare by vastly increasing the scope of what can be targeted, whether geographically or functionally, according to what precise strategic effect is being sought. NATO refers to this as hybrid warfare. Unlike traditional weapons, which have a limited range or impact (think of a missile that causes a finite amount of damage in a single location), a cyberweapon has multiple, simultaneous purposes. It can be used for intelligence gathering, data compromise and manipulation, disruption, actual physical destruction (along the lines of the Stuxnet worm), or information and psychological operations exploiting fake news or propaganda. These effects can either be achieved individually or simultaneously in a combination of both data exfiltration and disruption. The multifaceted and multi-effect character of cyberweapons makes them attractive from a cost-effectiveness standpoint, but it also means that their use may lead to unintended consequences. As we have seen with Russia's hacking into election campaigns in the United States and Europe, the victims may interpret the hostile intent as greater than what the attacker was intending to achieve; for instance, as an aggression or violation of sovereignty when the attacker meant only a probe or minor provocation. As collateral damage can be more widespread in the cyber domain than elsewhere, the number of potential victims, and therefore of potential outraged retaliators, is large. Think for instance of the NotPetya attacks against the Ukrainian MEDoc tax-filing system that, according to Lloyd's of London, led to U.S. \$8 billion in losses among international companies, including the Danish shipping company Maersk, whose international container traffic was disrupted for weeks. ${ }^{10}$ A number of Western intelligence services, including those of the UK and the United States, attributed the attack to Russia and called for more international sanctions. ${ }^{11}$ So even if the cyberattack is successful against its initial target, the issue is whether the wider fallout can be controlled.

In this respect, 2016 was, in many ways, a watershed year, when cyberdefense was no longer purely a question of protecting networks against a growing and more sophisticated spectrum of cyberattacks but instead became an issue of the integrity of democratic institutions in NATO countries. The abuse of cyberspace became a means not just to acquire or manipulate data, or interfere with the running of a particular network, but also to influence political outcomes and even exert outright political coercion and intimidation. Great publicity surrounded Russia's penetration of the networks of the Democratic National Committee in the United States and its use of extracted email information to discredit the election campaign of Hillary Clinton and the Democratic Party. It was not just the success of the attack that was striking but the fact that the Russian Foreign Intelligence Service tried to access as many as 128 private email 
accounts of the Clinton campaign and only ultimately needed to access two in order to be able to extract sufficient data to achieve - courtesy of WikiLeaks-a devastating impact. As far as we know, this Russian operation started in 2014 and was still going in October 2017, when it was finally shut down. About 100 Russian operatives are thought to have been involved, with several thousand accounts on social media and more than 50,000 bots amplifying the disinformation messages, also picked up by state propaganda, such as RT and Sputnik. In short, a major operation. In the past, force had to be used to change a government or regime from the outside. Could this now be achieved by a cyber-facilitated information operation? The U.S. election campaign was only the tip of the iceberg, as there were many other attacks, for instance, against the German Bundestag (parliament), the parliament in Austria, the presidential election campaign of Emmanuel Macron in France, or the prime minister's office in the Netherlands, which were designed for the same purpose of gaining leverage over political processes or destabilizing candidates in close-fought election campaigns. States that hitherto had been rather discreet about their role in these cyberattacks made less of an effort to deny them. Groups such as APT28 and APT29, commonly known as Fancy Bear and Cozy Bear, achieved great public notoriety. Currently, any form of political dispute seems automatically to lead to a series of cyberattacks, both as an expression of anger as well as a more systematic attempt to undermine an adversary by gathering potentially compromising information. The leak of data from the World Anti-Doping Agency and attempts to hack into the testing laboratories at the Rio 2016 Summer Olympic Games revealed that this type of revenge attack extends as much to the world of sport as of politics-indeed potentially to anywhere where a score needs to be settled. ${ }^{12}$

In sum, 2016 was the year when the cyberthreat ceased being a concern primarily for individual entities, such as banks, critical infrastructure providers, or hospitals worried about losing data, to become an instrument of hybrid warfare, where the state and society are virtually under permanent attack. The problem with cyber is that, because it is so easy to use, states may decide to attack targets and risk an increase in international tensions that they would probably refrain from doing if they had to use more conventional and overtly aggressive means. So cyber blurs the clear distinction between war and peace and creates a sense that everything a state normally believes it has under control (its administration, election processes, critical infrastructure, key supply chains, and economy) is now being contested or is even under permanent siege.

Given this multiplicity of cyber threats and attack vectors, the concept of what a state needs to defend has shifted. It is now no longer a specific strategic asset, such as an oil refinery or airfield, or a particular invasion route, such as the Fulda Gap in Germany during the Cold War, but it becomes virtually any 
kind of critical national infrastructure-from undersea internet cables to banks; electricity grids; industrial control systems (ICS); telecommunications; and gas, oil, and water pipelines. ${ }^{13}$ The scope is almost endless. The state cannot hope to achieve full protection of all these complex and often interdependent networks alone. It has to prioritize and delegate protective responsibilities to the regional or local level or to the private sector that owns and operates much of this critical infrastructure. In terms of basic cybersecurity, it becomes the duty of care and risk calculation of the individual citizen. Cyberspace has rapidly become a domain where everyone is calling upon everyone else to take action. The individual calls on the bank to provide better protection, the bank demands better software from the tech company, the tech company recommends better insurance coverage, while claiming that it is only a platform to post and transmit data and has no particular responsibility for the content. Meanwhile, the state has to decide whether regulation or voluntary effort is the best way to induce companies and individuals to improve their cyber hygiene and restore trust in a cyberspace that is an increasingly important part of economic growth.

For military establishments and an organization such as NATO, fully establishing cyberspace as an operational domain imposes clear cultural shifts and organizational adaptations, with the follow-on impacts for all other operational domains. Cyberspace cannot be a separate silo but has to be integrated with all these other operational domains. Operations in cyberspace need to be designed to support conventional military activity, as a force multiplier, and vice versa. This means that commands must understand, trust, and be prepared to employ all capabilities and determine those situations where the use of a cyber effect would perform a military task more quickly, efficiently, or more cheaply than a conventional weapon. An example is the debate in the Barack $\mathrm{H}$. Obama administration during the Libya conflict in 2011 over whether to use cruise missiles or cyberattacks to take down Muammar Gaddafi's air defenses. ${ }^{14}$ This debate revolved around cost-effectiveness, durability of impact, and the international precedent that might be created by the U.S. use of military cyber capabilities. Essentially, it means understanding the characteristics of offensive cyber and what it can and cannot achieve and the risks in terms of cost-benefit analysis. Collateral damage is one such risk as cyber tends to have horizontal rather than vertical effects through the nature of the hyper-connectivity of the internet. When the Stuxnet worm was used in 2010 against the Siemens operating software at the Bushehr nuclear power plant in Iran, it was introduced via a USB stick outside the internet and was designed to infiltrate only one type of software. ${ }^{15}$ It was seen as preferable to military actions, because it was covert, highly specific, and a way to minimize violence even if hundreds of Iranian centrifuges would be incapacitated. Yet, it ended up on the internet and traces of Stuxnet were found subsequently in 36 countries. Thus, greater transparency 
will be needed between those allies, such as the United Kingdom, that have publicly announced their willingness to voluntarily contribute national cyber effects to NATO. Additionally, NATO commanders will need to identify which effects are potentially available, what are the targets to which they apply, and how quickly they can be generated in a crisis or conflict scenario, but above all what the actual impact and fallout of such cybereffects are likely to be.

NATO has defined a mechanism for this transfer of cyber effects from the nation to the NATO command structure under the political oversight and control of the alliance. A Cyberspace Operations Centre (CYOC) is being established at Allied Command Operations (formerly SHAPE) in Mons, Belgium, to enhance early warning, carry out strategic and operational planning, factor cyber realistically into NATO training and exercises, and define the scope of joint cyber/conventional operations. Soldiers, sailors, airmen and airwomen, and NATO civilians who operate in other domains must be as ready to support cyberspace operations as those who regularly operate in cyberspace are ready to support any other joint operation. This will without a doubt generate the need for more cyber defense specialists and also more training and education for senior military and civilian leaders across the NATO enterprise in both the military and political ramifications of using cyberspace. For instance, a recent crisis-management exercise organized by Estonia for EU defense ministers (called CYBRID), which simulated a series of cyberattacks against an EU maritime force in the central Mediterranean, revealed several weaknesses. First, one weakness was the reticence of attributing the attacks and the amount of evidence required to attribute them properly. Second, it was difficult to determine whether the characteristic of the attack was simply hostile behavior or actual armed aggression. Third, there was a weakness in the political willingness to assign blame, as well as weaknesses in the usefulness of a number of possible response or retaliatory options (the "toolbox"). This pointed to a need for better coordination from the top.

So, as with the evolution of nuclear deterrence in the 1950s, it makes little sense to develop cyber capabilities and technical expertise if the leadership has a poor grasp of the conditions determining if, when, and how a cyber effect can be used. There is also the possibility that cyber effects are designed foremost for deterrence purposes and signaling rather than for actual battlefield use. This means regular crisis management exercising to synchronize military and political thinking and decision-making cycles is required. Such exercises can help to develop a comprehensive set of crisis response options involving cyber and/or combined cyber and conventional actions. Over time, a basic understanding of attribution methodology needs to be acquired so that what is deemed sufficient at the national level is also adequate for other nations to adhere to and express solidarity through collective action. A good example of this, albeit in the area of 
chemical weapons, is the attribution by the British government to Russia of the Novichok nerve agent, used against two Russian citizens in Salisbury, United Kingdom, in March 2018. ${ }^{16}$ Once the UK's findings were presented to NATO and the EU, the member states simultaneously expelled a significant number of Russian diplomats and agreed to clamp down on Russian intelligence operations in their territories.

As these retaliatory actions become more frequent (e.g., Special Prosecutor Robert Mueller's grand jury recently indicted 12 Russian Main Intelligence Directorate [GRU] officers for their alleged involvement in hacking into the U.S. election campaign), it will also be important to analyze which of this expanding toolbox of responses below the threshold of an Article 5-type of military response actually has an impact in changing the strategic calculus and behavior of our adversaries. ${ }^{17}$ Or, in other words, what can be done to change the current calculus of cyber as a low-risk, high-gain operation into one that is high risk and low gain? For instance, do unilateral or collective retaliations work better over time than bilateral agreements, such as the 2013 U.S.-China agreement on restraint in cyberspace? ${ }^{18}$ What is the practical benefit of international norms and confidence-building measures, such as the two packages endorsed by the Vienna-based Organization for Security and Co-operation in Europe (OSCE)? ${ }^{19}$ At all events, it is clear that we still have a long way to go before states recognize the essential red lines of effective cyber deterrence and stability; for instance, noninterference in political processes, refraining from attacks on critical national infrastructure, refraining from attacks on the "public core" of the internet, agreeing on common standards for attribution, and agreeing that attacks on nuclear command and control or vital space observation and communication satellites are impermissible. Even if a universal agreement establishing these red lines (i.e., by the United Nations Group of Governmental Experts) still seems a long way off, embedding them in regional or "mini-lateral" frameworks such as the Association of Southeast Asian Nations (ASEAN), the Commonwealth, or the African Union seems possible, and NATO could usefully take them up in its own partnership frameworks. For instance, a mutual agreement on certain norms could be embedded in NATO's individual cyber cooperation agreements with partner countries, alongside the technical exchanges such agreements usually provide. A memorandum of understanding with Finland has already been concluded and can lead the way to similar agreements with like-minded countries, such as Sweden, Japan, Australia, and New Zealand.

While the alliance has to protect its own information networks and systems, the focus in the future will be on enhancing NATO's ability to achieve mission objectives in support of NATO's core tasks of collective defense, crisis management, and projecting stability to its partner countries in North Africa, the Middle East, Southwest Asia, and Eastern Europe. This requires a broaden- 
ing of focus from information assurance to mission assurance and the ability to expand protection from fixed sites with stable networks to mobile headquarters and deployed or even improvised networks. As NATO works more with partners, either in operations such as the Resolute Support mission in Afghanistan, or in defense capacity building and training programs, such as those currently in Iraq, Jordan, Tunisia, Moldova, Ukraine, and Georgia, bringing these partners up to a standard level of cybersecurity will become essential to ensure NATO's own mission effectiveness. The memorandum of understanding with Finland on cyber defense cooperation is a good example of how a NATO mechanism "at 29 " can be adapted to facilitate increased cyber interoperability with the more active partners. ${ }^{20}$

NATO commanders will need to understand their operational dependencies on cyberspace, assess the risks they pose, and prioritize mitigation measures and responses at the speed of relevance in a highly contested and cluttered environment with a tiny margin of error. In pursuit of this objective, five distinct lines of effort have been identified.

The first is to protect and defend NATO cyberspace against the full range of cyber threats. This means not only responding to individual attacks but, more importantly, upholding the resilience of critical networks at all times, even in a degraded environment, where some systems would be out of action altogether and others would operate suboptimally. Sufficient redundancy and rerooting capacity has to be built in to ensure that a critical mass of command and control and communications capability is available at all times. NATO and each ally is responsible for protecting its own segment of cyberspace, but NATO plays a key role in facilitation, maintaining situation awareness, and moving assets from one ally or tactical situation to another as a crisis or conflict develops. This needs strong federation and prior authority given to NATO commanders to initiate early action to upgrade the alliance's cyber defenses and increase situational awareness, possibly through more active, forward-leaning defense measures that need to be flexible and scalable, based on the intensity of operations.

The second requirement is enhancing necessary cyberspace capabilities. The NATO Defence Planning Process began in 2013 to assign a number of collective minimum targets to all allies to ensure a common baseline in areas such as national cyber emergency response teams (CERT), basic cryptography and encryption, and stepping up education and training. Over time, these force planning targets will become more demanding and specifically geared toward the individual shortfalls of each ally. The scope today covers the establishment of military CERTs and also of quantitative, as well as qualitative, planning targets. In particular, the emphasis is on setting up military cyber teams that relate directly to the protection of deployed forces, networks, and logistics in a collective defense operation, with configured skill sets. The defense planning 
process can help NATO commanders' oversight of an increasing inventory of NATO-relevant cyber capabilities, although making sure they are effectively available and what they can realistically contribute will need more work. Meanwhile, two iterations of the Cyber Defence Pledge have given NATO staff much more transparency about national cyber defense programs and where and how these are growing, aligning, and integrating cyberspace investments and talent with innovative and interoperable capabilities throughout the alliance. Identified gaps, particularly where they are common to a number of allies and not only particular to the ally concerned, can then be addressed through the NATO Defence Planning Process or Smart Defence cooperative projects. NATO has three of these ongoing at the moment concerning multinational capability development, a malware-sharing platform, and education and training through the creation of a NATO Communications and Information Academy in Portugal. The Cyber Defence Pledge also requires allies to self-assess their levels of preparedness and maturity against a number of benchmarks and different grading levels. This obliges them to take a whole of government view and has led a number of allies better coordinating the work of different ministries and tightening their national cyber defense structures.

NATO also helps individual allies to prepare through realistic training and exercises, such as Cyber Coalition and Locked Shields, which are held every year at the NATO Cooperative Cyber Defence Centre of Excellence in Tallinn, Estonia. These benefit from a cyber range that has been upgraded to meet NATO standards. The focus of recent exercises has been resilience, helping NATO commanders to better understand how cyber attacks against host nation infrastructures (e.g., electricity grids, telecoms, or fuel or water supplies) could inhibit military mobility in a crisis or the commander's capacity to support their forces in combat. As part of the scenario and recent exercise infrastructure for Locked Shields 18, the Virginia Port Authority has helped NATO better assess cyber risks to port and offloading infrastructure, while Siemens has helped to configure the cyber risks to NATO airbases. Developing and strengthening cyberspace capabilities needs also recognize and mitigate supply-chain risks in a globalized economy. Cost-effectiveness has to be balanced against quality and security, as in any organization. This has led the NATO Communications and Information Agency to set up a rigorous program of testing and evaluation of new products so that NATO can make more informed decisions about the likely benefits (and risks) associated with new equipment and technology, both at the procurement stage and throughout the life cycle management of the product.

The third requirement is ensuring that NATO's deterrence and defense is supported through the adoption of cyberspace as a domain of operations. The relationship between cyber and traditional deterrence is a complicated one. As said previously, cyber assets can lower the threshold of conflict by making inter- 
ference and coercion more attractive and easy. Whereas in the field of nuclear deterrence the possession of a small number of nuclear devices is sufficient to make a potential aggressor think twice, in the cyber area, deterrence can only be built up gradually and by a degree of trial and error. Resilience has to deny the aggressor the benefits of an attack through faster detection and recovery. It can make it harder to access and disrupt a target, and it is obviously the least risky form of deterrence because it is based on self-protection rather than holding an adversary's assets at risk. Yet, resilience cannot stop attacks or the acceptance of a high volume of damage and compromise. The hacker will still get through. Therefore, attribution has to take away the veneer of anonymity. Response measures have to raise the cost to the aggressor and international norms and codes of conduct need to establish clarity regarding unacceptable behavior, international condemnation, and potential sanctions or indictments.

To reach these objectives, the alliance needs to become more involved in resilience, mapping its vulnerabilities, and exercising comprehensive business continuity plans. The counterhybrid support teams that the recent NATO summit decided to establish, together with the advisory support teams and lists of trusted suppliers managed by NATO's Civil Emergency Planning Committee, can help allies ensure and demonstrate the resilience of their critical infrastructures. ${ }^{21}$ Memoranda of understanding also have been concluded between the NATO staff and 24 of its allies. They provide for points of contact and the sending of cyber rapid reaction teams and enhanced technical measures provided by the NATO Computer Incident Response Capability (NCIRC) Technical Centre to stricken allies upon request. These services help allies deal with specific incidents and collectively harness the diversity of the alliance when it comes to recovery options.

This comes together with persistent cyberspace defense, which is not just the theoretical capacity to defend but the actual willingness to respond to all the many and regular cyber attacks below the Article 5 threshold. If NATO is only willing to act once this red line has been clearly crossed, and if it then has only heavy military forces with which to respond, it risks miscalculation by an aggressor regarding NATO's resolve and unity. NATO may end up deterring itself more than the aggressor through fear of escalation and of an outright kinetic conflict. Here, strategic communications have a role to play in demonstrating that NATO is able to wield equivalent force in cyberspace as in the other domains. Increasing the visibility of cyber defense and highlighting the way in which cyber is being integrated into large-scale military exercises, such as the Trident Juncture or Trident Javelin series, conveys a message of capability and resolve. These efforts will not only dissuade would-be aggressors from attempting to intimidate any individual ally but also increase public confidence that NATO is addressing the evolving cyber threat. Some recent opinion pieces 
in the U.S. media, in particular calling for a "Cyber NATO," have shown a lack of awareness of just how much effort NATO is actually making in this area. ${ }^{22}$ In fact, the alliance is already on its third Cyber Defence Policy and associated Cyber Action Plan since 2002.

The fourth line of effort is integrating cyberspace into all aspects of joint operations. The need for all domains to support each other has already been mentioned. Cyberspace considerations need to be addressed in all military functions from intelligence and situational awareness to command and control. To federate the collection, decision making, and execution elements of the cyberspace domain, NATO is working to achieve a high level of interoperability among NATO and national cyberspace operational organizations and forces. We are pursuing in this way an Allied Joint Doctrine. The latter is needed to provide sufficient political guidance for conducting joint operations on land, sea, and air and through cyberspace. ${ }^{23}$ One key question is when the alliance's response to an attack should be exclusively through cyber means or through other instruments of power, particularly the armed forces. Is this something that should be specified in advance as a way to enhance deterrence, or is it best left ambiguous to keep a potential adversary guessing and to discourage any form of attack due to the uncertainty as to NATO's likely response? At all events, adherence to international law is a prerequisite to any use of cyber instruments by the alliance, and under agreed rules of engagement. Cyber is a murky area, and any doubt or disagreement among allies could delay rapid decision making. Yet, as much as it is right for allies to wish to assert political control, it is also incumbent upon them not to hide behind conflicting interpretations of international law as a pretext to delay responding. The NATO Cooperative Cyber Defence Centre of Excellence has already performed sterling service by facilitating the development of the Tallinn Manual on the International Law Applicable to Cyber Warfare (or Tallinn Manuals) on the international law on cyberspace, embracing both the spectrum above and below an Article 5 form of armed attack. $^{24}$ These manuals, although not a formal NATO position, have helped to clarify what is and is not permitted and have at least clarified beyond doubt that most existing international law applies perfectly well to cyberspace and is not a hindrance to proportionate self-defense or collective alliance responses. Again, high-level exercising under real-life and real-time conditions can tease out different approaches and interpretations of the constraints of international law that can then be reconciled before a major crisis occurs.

The fifth and final requirement for a coherent NATO vision and strategy of cyberspace is to foster unity of effort through building effective relationships. The criticality of linkages between NATO and the national force structures and cyberspace defense organizations of its number and key partner countries has already been emphasized. The new NATO command structure, with its 
focus on collective defense, logistics, and high-end combat operations, will have as one of its primary tasks the maintenance and development of coordinated cyberspace assessment and defense response options. These efforts will enable NATO to develop common readiness, response, and resilience plans and will enable NATO to train and exercise together in a realistic manner. This said, effective cyber defense is about much more than simply pulling all the strands with one's own organization together. True situational awareness needs good early warning indicators and warnings and the capacity to put individual attacks in a larger defense or strategic context. There has to be a way to fuse actionable information and intelligence from a variety of sources.

This civilian and military cooperation is arguably more critical in the cyber domain than in any other area of defense. The NATO Industry Cyber Partnership currently has bilateral agreements between the NATO Communications and Information Agency and 15 major companies. An incentive for industry is to be able to participate in Threat Vector workshops, where national intelligence services provide updates on strategic level trends and threats. Industry is also invited to observe the alliance's cyber exercises and to help develop scenarios and modules. An innovation hub and exchange is being planned to allow industry to test its prototypes and products on NATO's simulated networks, so that the alliance can stay ahead of the technological curve. A better understanding of innovation and its likely impact helps to identify new, cost-effective solutions much earlier in defining capability requirements. Given the speed of change and obsolescence in the high-tech sector, innovation has to be exploited early and quickly if the life cycle benefits are to be worth the investment. Therefore, the NATO Industry Cyber Partnership can be useful in helping industry to understand and interpret future capability requirements at the conceptual stage and work better toward NATO's needs. NATO can better appreciate what industry is able to provide. Procurements can only be delayed when organizations and industry start with false expectations of both requirements and the maturity of certain technologies. A willingness to experiment and to allow nascent technology and ideas to fail quickly to move on to more promising solutions is key to being successful. If cyberspace development is tied too rigidly to the long procurement cycles and fixed heavy platforms of conventional capability development, opportunities will be lost. The alliance will experience cyberspace as a vulnerability and a burden rather than as an asset that can make NATO's defense more powerful and give it a tactical and strategic advantage over its likely adversaries.

In conclusion, a significant portion of cyberspace falls outside the military domain and is managed and developed by the private sector. Successful cyber exploitation requires the military for the first time to be agile in operating far outside its own domain and mind-set. It is exploiting something for military 
use - the internet - that was not designed as a weapon and has to be preserved intact for its overall civilian purposes and usefulness as an instrument of human communication and social and economic fulfillment. An institution like NATO will need to make far-reaching organizational changes and determine how it reconciles a structure dealing with twentieth-century conventional conflict scenarios with the new warfare and technologies of the twenty-first century. It must be able to switch effortlessly between dealing with a heavy armored interstate conflict to a more population-centric hybrid form of aggression. Effective management of cyberspace is key in linking these two paradigms of conflict together and in ensuring that the synergies achieved in one area benefit deterrence and defense in the other. The organization, resource, and policy decisions that the alliance makes in the course of implementing this vision and strategy for cyberspace will have far-reaching implications for NATO's relevance and its ability to defend its populations for many years ahead.

\section{Notes}

1. Jens Stoltenberg, "NATO and Cyber: Time to Raise our Game," Defense News, 8 July 2016.

2. See paragraph 72 of the Wales Summit Declaration issued on 5 September 2014 by the heads of state and government participating in the meeting of the North Atlantic Council in Wales.

3. For further context, see Nuclear Posture Review, February 2018 (Washington, DC: Office of the Secretary of Defense, 2018). The United States would only consider the employment of nuclear weapons in extreme circumstances to defend the vital interests of the United States, its allies, and partners. Extreme circumstances could include significant nonnuclear strategic attacks. Significant nonnuclear attacks include, but are not limited to, attacks on the United States, allied or partner civilian population, or infrastructure and attacks on the United States or allied nuclear forces, their command and control, or warning and attack assessment capabilities.

4. "Cyber Defence Pledge," press release, NATO, 8 July 2016.

5. Dan Goodin, "Hackers Infect 500,000 Consumer Routers All over the World with Malware," Arstechnica, 23 May 2018.

6. Josh Fruhlinger, "The Mirai Botnet Explained: How Teen Scammers and CCTV Cameras Almost Brought Down the Internet," CSO, 9 March 2018. Fruhlinger explains that the internet of things includes "devices ... that most people don't think of as computers, but that still have processing power and an internet connection. These devices [range] from home routers to security cameras to baby monitors, [and] often include an embedded, stripped down Linux system. They also often have no built-in ability to be patched remotely and are in physically remote or inaccessible locations."

7. Dianne Apen-Sadler, "Britain's Youngest Convicted Terrorist, 14, Asks Courts for Anonymity for Life: Boy Plotted from His Bedroom to Behead Police Officers in Australia and Also Turn a Kangaroo into a Suicide Bomber," Daily Mail, 22 July 18.

8. See "Cyber-attack: US and UK Blame North Korea for WannaCry," BBC News, 19 December 2017.

9. Roxana Tiron, "Pentagon's 'Do Not Buy' List Targets Russian, Chinese Software," Bloomberg, 27 July 2018.

10. Suzanne Barlyn, "Global Cyber Attack Could Spur $\$ 53$ Billion in Losses: Lloyd's of London," Reuters, 17 July 2017.

11. See "UK and US Blame Russia for 'Malicious' NotPetya Cyber-Attack," BBC News, 15 February 2018. 
12. See as an example Alan Baldwin and Jim Finkle, "Anti-doping Agency Says Athlete Data Stolen by Russian Group," Reuters, 13 September 2016.

13. The Fulda Gap represents the shortest route (through the cities of either Fulda or Giessen) from the border between East Germany and West Germany to the Rhine River.

14. Eric Schmitt and Thom Shanker, "U.S. Debated Cyberwarfare in Attack Plan on Libya," New York Times, 17 October 2011.

15. Kim Zetter, "An Unprecedented Look at Stuxnet, the World's First Digital Weapon," Wire, 3 November 2014.

16. Tom McTague, "Theresa May Blames Russia for Nerve Gas Attack," Politico, 12 March 2018.

17. For more information, see United States of America v. Viktor Borisovich Netyksho, Boris Alekseyevich Antonov, Dmitriy Sergeyevich Badin, Ivan Sergeyevich Yermakov, Aleksey Viktorovich Lukashev, Sergey Aleksandrovich Morgachev, Nikolay Yuryevich Kozachek, Pavel Vyacheslavovich Yershov, Artem Andreyevich Malyshev, Aleksandr Vladimirovich Osadchuk, Aleksey Aleksandrovich Potemkjn, and Anatoliy Sergeyevich Kovalev, U.S. District Court for the District of Columbia, 2018.

18. "Fact Sheet: President Xi Jinping's State Visit to the United States," press release, White House President Barack Obama, 25 September 2015.

19. Organization for Security and Co-operation in Europe, "Decision No. 1202 OSCE Confidence-Building Measures to Reduce the Risks of Conflict Stemming from the Use of Information and Communication Technologies," PC.DEC/1202, 10 March 2016.

20. "About NRC," NATO-Russia Council, accessed 10 November 2018. Russia and NATO member states meet as equals "at 29" in areas of common interest-instead of in the bilateral "NATO+1" format under the Permanent Joint Council (PJC).

21. See paragraph 21 of the "Brussels Summit Declaration," press release, NATO, 11 July 2018.

22. See, for instance, Marc Rod, "Democrat Joaquin Castro Calls for 'Cyber NATO'," CNN, 18 July 2018; and Adm James Stavridis, "NATO's Real Spending Emergency Is in Cyberspace," Bloomberg, 18 July 2018.

23. Allied Joint Doctrine, Allied Joint Publication-01, ed. E, ver. 1 (Brussels, Belgium: NATO, 2017).

24. For further information on the Tallinn Manual process, "Tallin Manual Process," NATO Cooperative Cyber Defence Centre of Excellence. 


\title{
Toward a European Defense System How the European Union Should Improve Its Planning and Conduct Capacity for the Prevention and Management of Crises
}

\author{
Lieutenant Colonel Ivan Falasca, ITA Army Marine
}

\begin{abstract}
The European Union (EU) needs to improve its capability to plan and conduct comprehensive civil-military measures for the prevention and management of crises. The aim of this article is to propose one possible solution that sees the creation of an integrated structure consisting of two directorates. This new structure would optimize the planning and conduct of EU interventions at the strategic level and support the introduction of a new type of integrated mission, which is a mission where the civil, police, and military components are combined into a single structure. The proposed solutions will form the foundation of a European defense system and will improve the EU's rapid reaction intervention capability.
\end{abstract}

Keywords: European Union defense, North Atlantic Treaty Organization, NATO, European strategy, integrated mission, European External Action Service, EEAS

he added value that the EU can bring to the defense and security sector
in comparison to a military alliance such as NATO lies in its capabili-
ty to deliver a comprehensive action on behalf of 27 European states.

LtCol Ivan Falasca worked as a staff officer at the Policy and Plans Division of the Italian Joint Staff. During this experience, he dealt with the Italian defense policy in the framework of the European Union, and he worked directly on the Italian defense contribution for the new European security strategy. He attended Command and Staff College and the School of Advanced Warfighting at Marine Corps University. He is currently the battalion commander in the Italian Army Marines Regiment. 
This is achieved by combining in a synergistic manner the full spectrum of political, economic, and military instruments. In this context, it is important that the policies of the European Commission, the Common Foreign Security Policy, and the Common Security and Defense Policy are fully coherent. This cohesion requires Common Security and Defense Policy interventions characterized by an internal integration between civilian and military components, to be easily inserted into a broader framework that would include the in-theater activities of EU special representatives, the directorates-general of the European Commission, and other organizations and international agencies. This is even more important because the EU is currently conducting civil missions and military operations that are poorly coordinated and sometimes contain different chains of command within the same theater of operations. Furthermore, the integration between civilian and military components is a necessary step toward a comprehensive approach in crisis management.

Presently, there are three significant shortfalls in the existing Common Security and Defense Policy architecture for interventions. First, there is a discontinuity in the command and control structure between the politico-strategic level and the military-strategic level because the EU does not have a permanent headquarters at the operational level. Second, there is a poor integration between the civilian and military component in the political-strategic and strategic structures in Brussels. Third, there is a disconnect between civilian missions and military operations, even though they operate in the same geographical area, both from a point of view of command and control and of the financial mechanisms. These shortfalls considerably weaken the EU's capability to plan and conduct comprehensive civil-military measures for the prevention and management of crises. There are already ongoing debates and initiatives on how to overcome these shortfalls. To this aim, a great opportunity comes from the recently approved security strategy document Shared Vision, Common Action: A Stronger Europe: A Global Strategy for the European Union's Foreign and Security Policy. ${ }^{1}$

Within the context of these shortfalls, initiatives, and opportunities, the aim of this article is to propose one possible solution: the creation of an integrated structure consisting of two directorates. This new structure would optimize the planning and conduct of Common Security and Defense Policy interventions at the strategic level and support the introduction of a new type of integrated mission, which is a mission where the civil, police, and military components are combined into a single structure. The proposed solutions will form the foundation of a European defense system coupled with the improvement of the EU's rapid reaction intervention capability. 


\section{The Root of the Problem}

Multiple emergencies and rapidly evolving global trends have undermined the EU's role as a security actor with three main implications: instability surrounding the EU, financial crisis and austerity measures that weakened military capabilities and resources, and the rise of new economic and demographic realities that switched the world's economic center of gravity away from Europe.

Despite the fact that the European continent has enjoyed a long period of peace, instability has spread in its neighboring regions, from the Middle East and North Africa region, including the Sahel and the Horn of Africa, through the Caucasus, and up to the eastern boundaries of Europe. Moreover, the evolution in the post-bipolar security environment has led to the development in those areas of various threats that spread across political, social, and economic dimensions and are increasingly interconnected. In particular, these threats range from the proliferation of weapons of mass destruction to cyber attacks, piracy, the actions of ethnonationalist groups with subversive intentions, and threats to energy and environmental security. Globalization acts as an ideal vehicle for these threats spreading across national borders, blurring the line between internal and external threats. Hybrid warfare also represents a common threat and a source of instability to all European Union member states.

The first blow to the European balance of peace came from the 2014 Russian aggression against Ukraine and its indirect threat to the integrity of EU territorial water and air space. This act of aggression also has reminded Europeans of the specter of a military attack and occupation on European soil. Even if the Ukrainian crisis affected member states in different ways, as it exposed the fragility of the gas supplies, the EU members' reactions were uncoordinated, which suggested that it was a problem only for Eastern and Central Europe. ${ }^{2}$ In the same way, the implosion of the situation in the Middle East and North Africa region and the resulting migration flow appears to be a problem only for the member states in the south, while the threat of terrorist group infiltration within migrants should be a concern for all member states. Consequently, the difference in threat perception and security concerns among member states is preventing the emergence of a common strategic culture and the creation of joint procedures and assets for all EU member states to face crises.

The second implication of the current global scenario that undermined the EU's role as a security actor is the financial crisis and the resulting austerity measures that heavily affected the defense budget in EU member states. The trend of downsizing the military budget started after the fall of the Soviet Union in 1989. Indeed, the rising costs of new technological weapons and increased skepticism from the public about the role of the military made it difficult for European governments to justify high levels of defense expenditures. ${ }^{3}$ However, 
the recent increasing levels of threats and public concerns allowed the EU member states to increase the defense budgets, even a very modest amount, in line with the austerity measures still governing the economic policy of the EU states. However, these efforts resulted in a series of duplicated capacities, platforms, and systems that are not interoperable. Despite the fact that EU member states have modestly increased their defense budgets, they are investing in military equipment in an inefficient way instead of coordinating strategy and spending.

To make matters worse, the rising powers in the eastern part of the world, especially China, have caused a shift of the world's economic center of gravity away from Europe. Consequently, the percentages of defense expenditures have changed all around the world. The emerging economies in the East are closing the gap and will soon outdo the Western countries in defense expenditures. China has increased its budget by 150 percent during the past decade, with a further rise of 7 percent expected in 2017, while Russia invested 5.4 percent of its gross domestic product on defense last year. ${ }^{4}$ The main consequence of this new assertiveness of the emerging powers will be in terms of more tensions and insecurity. In an increasingly threatening world, it is evident that the EU should enhance its ability to act as a security provider to regain its influence on the world stage. The only way to become a security provider is to act with a unified will and not through the initiative of individual member states.

The rise of EU defense capability will also benefit NATO, considering that of the $28 \mathrm{EU}$ member states, 22 are NATO allies. Indeed, the transatlantic alliance needs the EU to increase its military capability and its will to invest in defense matters. Otherwise, the risk for NATO is to become an alliance of "collective military irrelevance," as pointed out by the former U.S. secretary of defense, Robert M. Gates.

Numerous emergencies in the EU's strategic neighborhood, hybrid security threats, years of uncoordinated cuts in defense spending, and rapidly evolving global trends have all eroded the EU's role as a security actor in a multipolar world. The EU is facing the problem of not having its own military instrument, which would enhance its strategic autonomy and its ability to act as a security provider on the international stage. The need for a defense system is more evident considering the increasingly tense global security environment, characterized by the build-up of troops on the EU's eastern borders, war and terrorism in the Middle East and North Africa region, and increasing militarization around the world.

\section{How the EU Can Optimize the Planning and Conduct of Common Security and Defense Policy Interventions}

Within the ongoing debate to overcome the already cited shortfalls in the 
Common Security and Defense Policy architecture for interventions and reinforcing the European External Action Service's capability to plan and conduct civil-military measures for the prevention and management of crises, member states are discussing some possible options. This includes the establishment of a permanent operation headquarters at Brussels and the optimization of the already existing Common Security and Defense Policy structures. Meanwhile, the EU has introduced an unprecedented multidimensional approach in the Horn of Africa through a series of measures including:

1. The activation of the operations center with the task of coordinating and supporting the three Common Security and Defense Policy interventions in the area;

2. The nomination of a special representative;

3. The development of a regional strategy (i.e., A Strategic Framework for the Horn of Africa);

4. The establishment of numerous coordination mechanisms including, for example, the Capacity-Building Coordination Plat-form and the Shared Awareness and Deconfliction (SHADE).

\section{Assumptions and Constraints}

For the purpose of this article, it is important to formulate assumptions that are at the base of the proposed solution to optimize the Common Security and Defense Policy conduct and planning capabilities for crisis prevention and management. Furthermore, assumptions in this case are necessary considering the political nature of the EU, and in particular the fact that in the defense field the EU cannot adopt resolutions that are binding for the member states. Therefore, it is assumed that:

1. Member states would not be able to commit additional significant financial and personnel resources in the European External Action Service's planning and conduct capability.

2. EU common security and defense management operations will be of a civil-military nature and will adopt a holistic approach.

3. The current organizational structure of the Common Security and Defense Policy can be changed.

Other than these assumptions, this article considers the following constraints to make the proposed solution as concrete and feasible as possible:

1. The European External Action Service's planning and conduct capability must not duplicate NATO's capability.

2. The structure for the planning and direction of operations must be able to meet the EU's level of ambition.

3. The new structure shall not include any additional personnel, except 
for a possible contribution of a maximum of two additional personnel made by each member state.

\section{Proposal}

The current EU architecture at the strategic level for crisis management encompasses three main bodies: the Civilian Planning and Conduct Capability, the Crisis Management and Planning Directorate, and EU Military Staff. Furthermore, the EU has at its disposal, in the case of military operations, the decentralized operational headquarters that the EU can activate for a particular intervention (i.e., EU Italian Operational Headquarters-Rome is activated for EU Naval Force, Mediterranean's Operation Sophia). ${ }^{6}$

To optimize its planning and conduct capabilities, the EU should establish a single integrated civil-military structure at the political-strategic level called the Integrated Civilian-Military Directorate and a single integrated civil-military structure at the strategic level called the Missions and Operations Directorate. These two structures could be created by using the resources readily available in the existing Crisis Management and Planning Directorate, Civilian Planning and Conduct Capability, and EU Military Staff. They could be augmented by other personnel drawn from the five national framework operational headquarters, together with a minimum contribution (one or two people) from the member states. The functions performed by the existing structures (Crisis Management and Planning Directorate, EU Military Staff, Civilian Planning and Conduct Capability, operations center, and operation headquarters) should be reallocated to the two new directorates according to criteria that optimize output rather than the retention of current competencies. Indeed, the EU needs integrated structures that are able to develop comprehensive plans for crisis prevention and management, rather than multiple entities, each of which is in charge of a single aspect that is not coordinated with others. These resulting structures, physically located in Brussels, would facilitate every possible interaction and synergy among themselves and with other EU bodies. The strictly functional support to the EU Military Committee would continue to be guaranteed by EU Military Staff of about 20 personnel. ${ }^{7}$

At the political-strategic level, the Integrated Civilian-Military Directorate (figure 1) would be responsible for the management and planning of the interventions in crisis areas. Therefore, the conduct of the advance and crisis response planning would fall under the responsibility of the Integrated Civilian-Military Directorate. This would include the development of the crisis management concept, the military/civilian strategic options, and the Initial Military Directive. This new integrated structure would be able to improve relationships and synergies with other European Union External Action Service bodies (geographic desks for each area, delegations around the world, etc.), 
Figure 1. Proposed organizational chart for the Integrated Civilian-Military Directorate (ICMD)

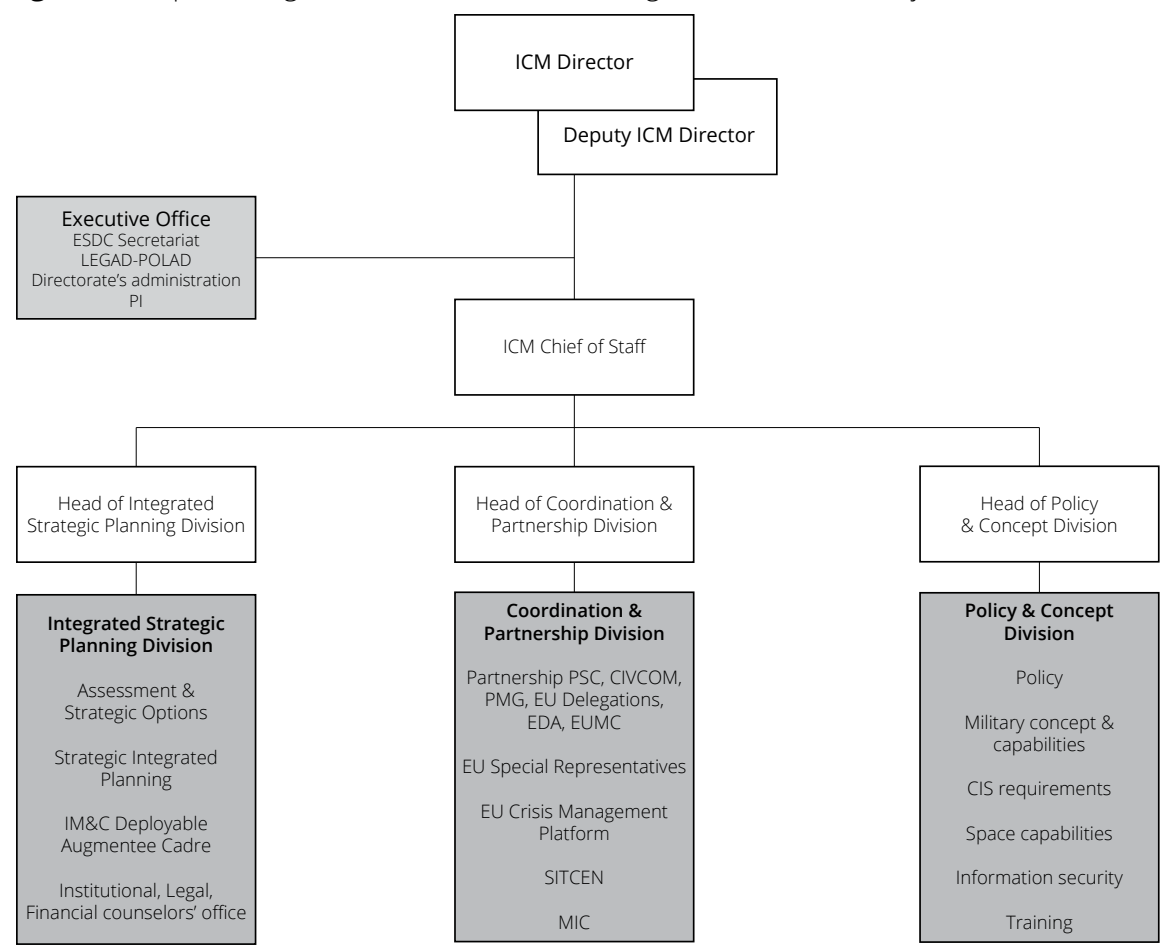

Source: courtesy of the author, adapted by MCUP.

relevant directorates-general of the European Commission, and the member states (through the Political and Security Committee) to implement effective coordination of all available instruments.

At the civil-military strategic level, the Missions and Operations Directorate (figure 2) would exercise command and control of military operations and civilian missions. Strategic planning and conduct would fall, therefore, within the Missions and Operations Directorate's remit (figure 3). The Missions and Operations Directorate director would, therefore, be the "commander" of the all the EU's Common Security and Defense Policy interventions under the political control and strategic direction of the Political and Security Committee and the authority of the high representative. The directorate would use integrated planning and conduct teams, drawing on the resources of all three of its divisions/offices, in order to meet the demands of each individual mission/ operation.

At the operational level, the new structure introduces the possibility of undertaking a new type of Common Security and Defense Policy intervention to be financed with a single funding stream. Consequently, all components (civilian and military) operating in a defined area are placed under the command of a single head of mission. In the initial phase of planning and initiating a mission 
Figure 2. Proposed organizational chart for the Missions and Operations Directorate

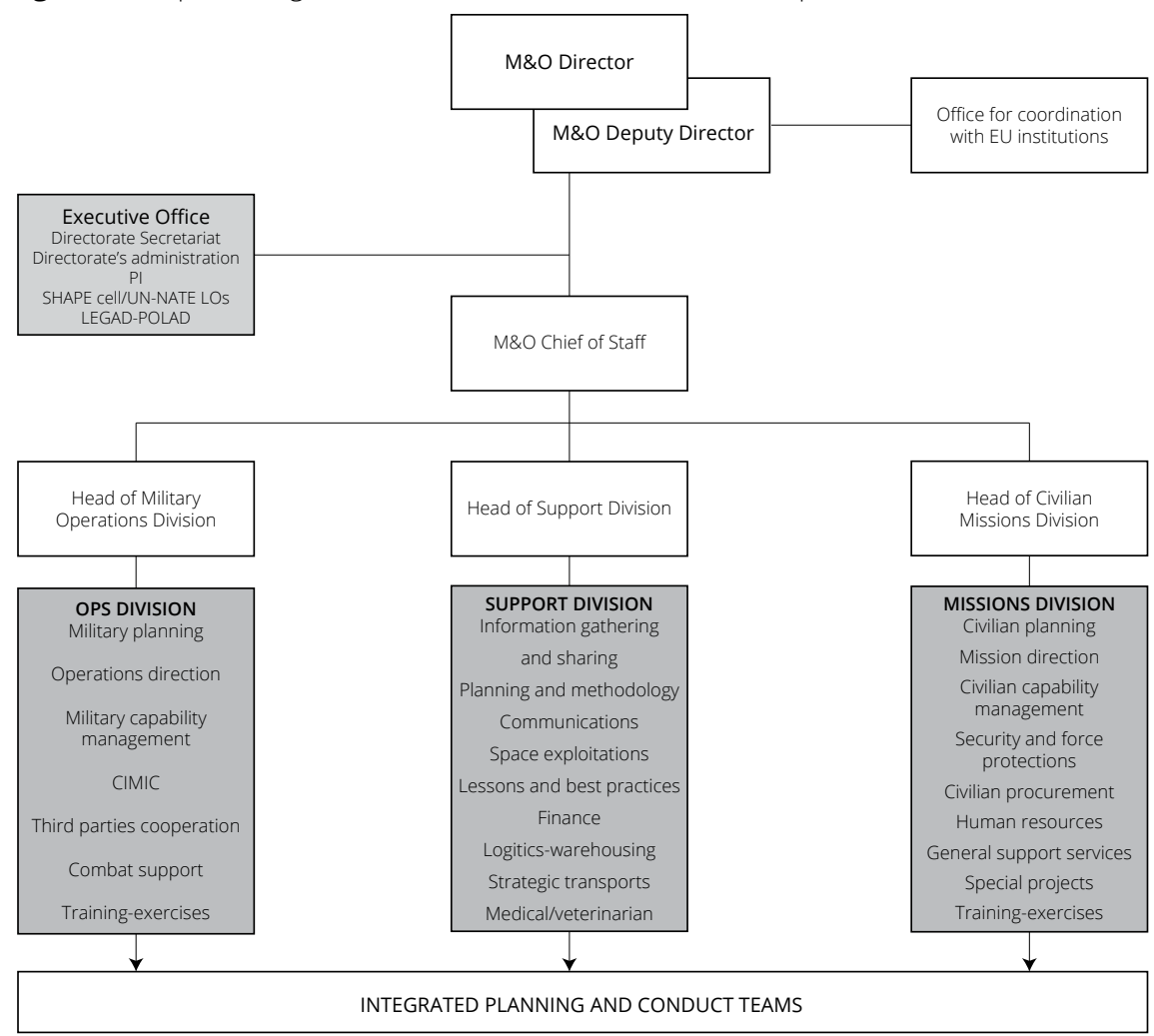

Source: courtesy of the author, adapted by MCUP.

Figure 3. Planning process within the EU Institutions according to the "Crisis Management Concept," integrating the new structures

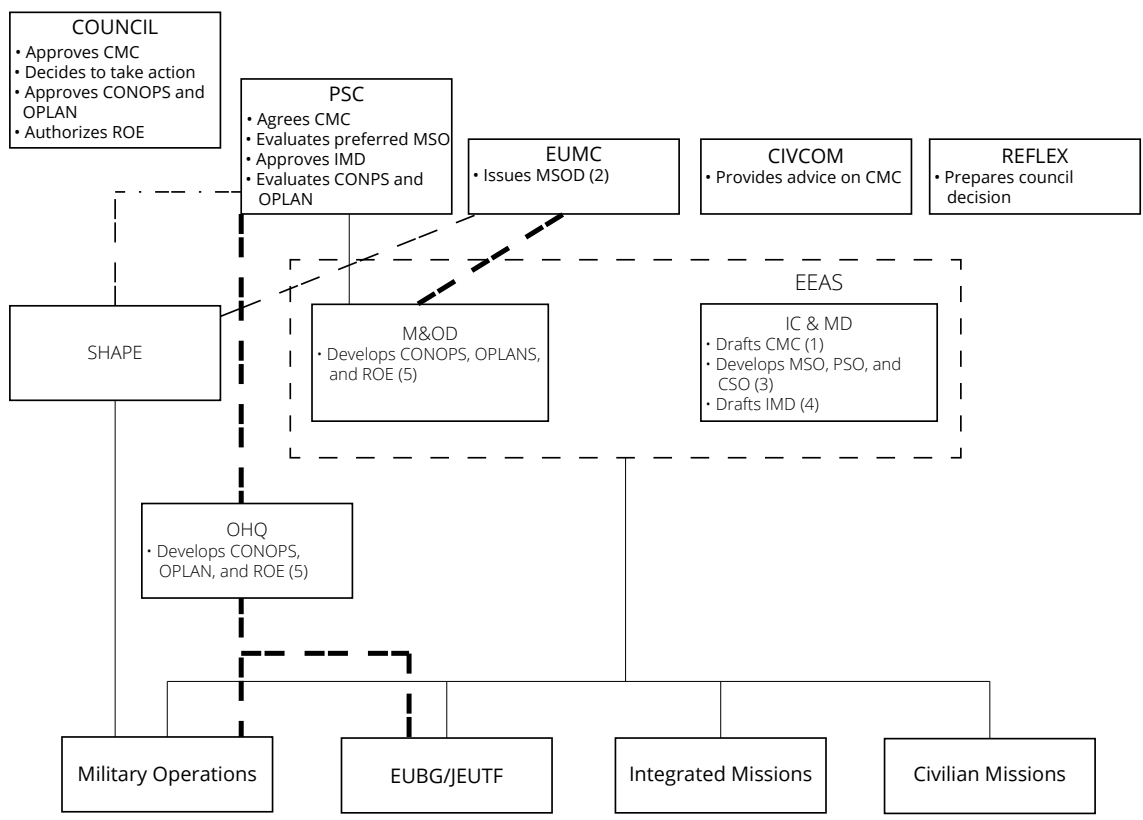

Source: courtesy of the author, adapted by MCUP. 
or operation, the head of mission/force commander would be supported by a team of planners, both civilian and military. The Missions and Operations Directorate would temporarily detach this team, thus allowing the head of mission/force commander to develop their own planning documents in full compliance with the concept of operations and the operation plan produced at the strategic level.

\section{Consequences}

It should be noted that one of the consequences of this reorganization is that the standby EU Battlegroups would be under the direct control of the Missions and Operations Directorate. This would generate substantial savings by avoiding the activation of two different operational headquarters every six months and the related agreements that currently have to be developed for each successive EU Battlegroups. Furthermore, it would markedly increase the degree of EU Battlegroup standardization in the preparation and validation phases. Another consequence would be eliminating the need for ad hoc organizations in Brussels, such as the current operations center, to support planning and coordination. These tasks would be fulfilled by the Missions and Operations Directorate with its integrated planning and conduct teams.

Finally, the need to have, for solely military interventions, an operational headquarters as a command and control structure at the strategic level would be greatly reduced. In particular, the EU would limit the activation of an operational headquarters to very complex and/or high-intensity interventions for which the European countries would opt for an application of the Berlin Plus agreements and would use the Supreme Headquarters of Allied Powers in Europe as operational headquarters (as for the most recent case for the operation ALTHEA).

Financially, the implementation of the proposal would present limited transitional costs, primarily involving the expansion of the Missions and Operations Directorate Communication and Information System component by utilizing facilities already available at the Civilian Planning and Conduct Capability and the European Union Military Staff Operations Centre/Watch Keeping Capability. Thus, it is fundamental to understand that the Missions and Operations Directorate would be configured as a civil-military integrated center for the direction of military operations, civil missions, and integrated missions. Therefore, at least initially, it would need Communication and Information System capabilities to be able to perform the aforementioned function. In evaluating the cost-effectiveness of this proposal, all those costs related to initiatives that would be carried out to fill the European Union External Action's current capability gaps should not be included (e.g., 
the enhancing of mission planning capabilities and the creation of a protected computer network).

\section{Intermediate Steps}

The Common Security and Defense Policy has demonstrated a lack of some of the necessary capabilities in terms of planning and conducting interventions, especially for nonexecutive military missions (training, advising, monitoring, mentoring, etc.). Indeed, the mission commander lacks the necessary support for the conduct of military planning at the strategic level, which is normally carried out by the operational headquarters for executive military operations. Therefore, they must assume all responsibilities at both strategic and operational levels. This forces the mission commander to go back and forth between the theater and Brussels, while their physical presence is crucial to exercising command and to providing the necessary coordination and interaction with third parties within the theater of operations, not to mention the increased workload. The EU, to develop its ambition of a wider comprehensive approach, should progress toward an increased synergy among civilian activities and military operations. This could be delivered by a more integrated civilian-military structure and synchronization at the strategic level in terms of Common Security and Defense Policy structures.

In the short to medium term (two to five years), with the aim of optimizing the planning and conduct of nonexecutive military missions and the ongoing discussion of the future of the activated operations center, a possible avenue to overcome the Common Security and Defense Policy's shortfalls could be strengthening the role of the European Union Military Staff. In particular, the European Union Military Staff could take over the responsibilities of the military commander for the conduct of military planning of nonexecutive missions at the strategic level and the functions of the activated operations center, while retaining its current tasks. In this perspective, the resources of the activated operations center would be absorbed by the European Union Military Staff. In such an approach, the European Union Military Staff, whose title could be European Union Military Staff plus, would be capable of planning and conducting nonexecutive military missions and would continue to provide added value to existing Common Security and Defense Policy activities in the Horn of Africa in terms of coordination support. ${ }^{8}$

In the long term (5-10 years), we could envision bringing together homogeneous EU interventions to external conflicts and crises (in the field of security sector reform) in one single command and control structure (that we could call "Civ-Mil Missions Directorate") for the planning and conduct of both nonexecutive military and civilian missions. The aim would be to deliver the vision of a greater synergy between civilian and military activities and to 
consider the likelihood of a growing trend toward capacity-building activities. In such a view, the new structure would absorb the functions and recourses of the Civilian Planning and Conduct Capability and a portion of the so-called European Union Military Staff plus to be capable of planning and conducting all Common Security and Defense Policy missions (civilian and nonexecutive military). In this perspective, the European Union Military Staff would resume current duties and provide coordination for Common Security and Defense Policy activities that exist in the same geographical area.

\section{Considerations}

The so-called European Union Military Staff plus would constitute a permanent structure in Brussels, for the planning and conduct of an increasing number of military missions with nonexecutive mandates. This includes the early stage of the planning, pending the nomination of the military commander, as well as the force generation process. In addition, it preserves the added-value functions currently provided by the activated operations center.

The proposed avenues draw upon existing resources-in relation to the desired output — and neither changes the way the EU develops executive military operations, nor does it duplicate existing international organizations in the area of security, such as NATO. As far as human resources are concerned-if deemed necessary - manpower could be strengthened by seconded national experts provided on a voluntary basis by the member states. In addition, the longterm vision would improve the civilian-military cooperation and interaction. Indeed, the new structure (the Civ-Mil Missions Directorate) would optimize the planning and conduct of civilian missions that include military components, promoting the pursuit of a wider comprehensive approach. Lastly, as an added value in such an approach—since homogeneous EU crisis responses, in the field of security sector reform (both civilian and nonexecutive military missions), would be brought together under a single structure-it would be possible to finance those military missions with nonexecutive mandates and all civilian missions through the same funding mechanism, scaled accordingly. ${ }^{9}$

\section{Improvement of the Common Security and Defense Policy Rapid Reaction Intervention Capacity}

During the last three years, the EU's institutions have been trying to find and propose potential solutions aimed at improving the EU Battlegroup institution. Among recent proposals, for example, was the possibility for member states to contribute to the EU Battlegroup's forces list with niche capabilities by a modular approach (organic units, even small ones) or by a proportional number of units depending on if they are a framework nation (responsible for the command of the EU Battlegroup) or only a contributing nation. However, all these 
proposals are not in themselves capable of resolving the current constraints that impact the use of the EU Battlegroup and the member states' contributions to it. These shortfalls were recently demonstrated at the outbreak of the crisis in the Sahel, which culminated with the launch of the military operation European Union Training Mission in Mali, where the EU Battlegroup was not and could not be used. For this reason, it is believed that it is necessary to improve the current rapid reaction intervention capacity to increase flexibility and effectiveness.

The reason for the lack of political will that affects the usability of the EU Battlegroup has to be identified in the planning horizon of the EU Battlegroup, which is about five years, in accordance with the current concept. ${ }^{10}$ This means that member states who commit today would not be eager to deploy their forces within five years to address a situation of crisis, especially if they do not have specific concerns over that crisis. For these reasons, it is necessary to seek a solution aimed at complementing the current planning horizon framework with other options and, to do this, it is necessary to amend the EU Battlegroup concept.

A potential solution consists of differentiating the nature of the European rapid reaction formations and amending, accordingly, the EU Battlegroup concept, transforming it into a wider rapid reaction intervention capability concept. To this end, on the one hand, the current EU Battlegroup must evolve into a joint military rapid reaction formation, which has the necessary capabilities to establish efficient and reliable links with civilian actors in the field and that can be used effectively across the whole spectrum of its potential tasks to increase its deployability. On the other hand, there should be introduced, under the same (but expanded) concept, Joint European Expeditionary High-Readiness Task Forces to react to specific threats and potential emergencies.

At any time, at least one EU Battlegroup should be kept in standby status under the protocols of the current EU Battlegroup concept (i.e., as a rapid reaction force to deal with immediate and unpredictable crises while promoting military transformation and integration among all member states). The effectiveness of this EU Battlegroup could be improved by leveraging the concepts of framework nations and modular employment and also through the inclusion of military niche capabilities and a civil outreach capacity. A Joint European Expeditionary High-Readiness Task Force (JEUTF), however, could be swiftly created and tailored to the specific requirements of an emerging crisis. This Joint European Expeditionary High-Readiness Task Force will not be generated in line with the existing force generation process planning horizon for the EU Battlegroup but would be established when necessary even with a short notice, and its standby period of up to twelve months would be determined by contributing nations (figure 4). 
Figure 4. Current and proposed EU Battlegroup planning horizon
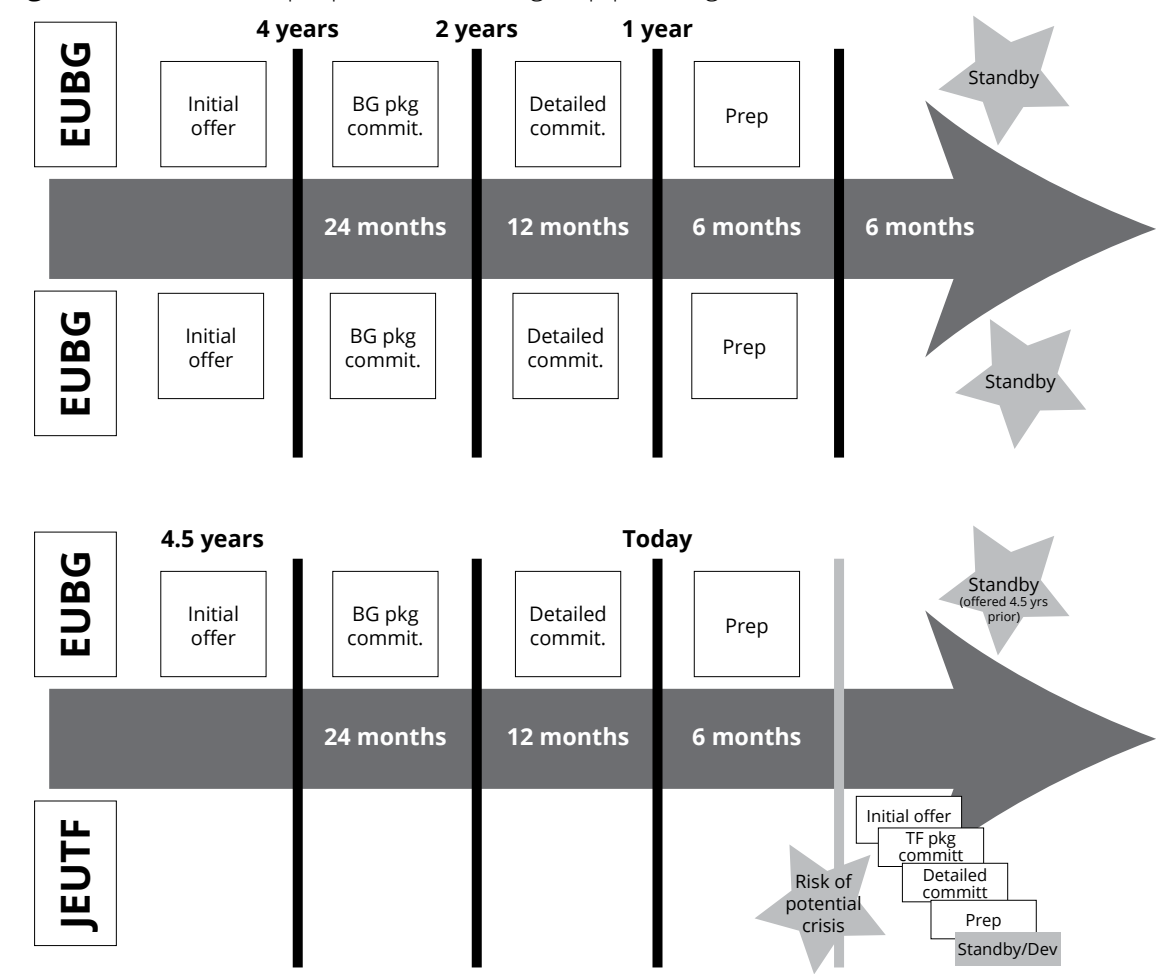

Source: courtesy of the author, adapted by MCUP.

Such a JEUTF could be formed, on a volunteer basis, by groups of member states with shared concerns over a developing crisis when the EU deems it necessary to be prepared to address a specific potential crisis. The establishment of a Joint European Expeditionary High-Readiness Task Force could positively influence the situation in the field well in advance of the actual development of the crisis by highlighting the concrete commitment of the EU to a rapid intervention if needed. In addition, these JEUTFs could be used, with a predefined set of assumptions, as an "entry force," an "over the horizon force," for humanitarian assistance missions, or for training and advisory missions. Accordingly, Joint European Expeditionary High-Readiness Task Forces would provide an immediate intervention capability for specific threats or emergencies, which would take longer to obtain through the standard force generation process and is not guaranteed by a traditional EU Battlegroup in standby.

This solution would be even more effective if, during their standby period, the battle groups/task forces were to be placed directly under the control of a Common Security and Defense Policy structure in Brussels with strategic responsibility for the planning and conduct of preparation and employment. To facilitate a more equal burden share between the member states it would 
also be necessary to identify new funding mechanisms for the EU Battlegroup and the Joint European Expeditionary High-Readiness Task Force, foreseeing reimbursement broader than that currently provided by the Athena mechanism. ${ }^{11}$

\section{Pooling and Sharing for Operations: A Pragmatic Common Security and Defense Policy Approach}

Future Common Security and Defense Policy operations should be approached in a more pragmatic way to maximize operational results, to reduce the individual burden of member states, and to share responsibilities among those member states who are willing to take part in the operation.

At the outbreak of a crisis, a multinational EU force could be swiftly created and tailored to the specific requirements of the emerging crisis itself. This multinational force would be established when necessary, even on short notice, following a specific initiative of a framework nation when the EU deems it necessary to be prepared to address the crisis. Such a force could be formed, on a volunteer basis, by groups of other member states with shared concerns over the developing crisis. The prompt establishment of this force could positively influence the situation in the field by highlighting the concrete commitment of the EU to a rapid intervention. The framework nation could volunteer to address a specific crisis on the basis of the will and the capacity to act, in relation to the proximity of the crisis area (reducing deployment/redeployment related costs), and specific knowledge of the region and environment. Other nations could join the operation by offering a specific package of forces or capacities (e.g., intelligence-surveillance-target-acquisition-reconnaissance (ISTAR) assets; logistics; strategic airlift/air-to-air refueling (AAR); intelligence; staff personnel; and C4I-command, control, communication, computer, and information) in a sort of pooling and sharing procedure tailored to operations. In shaping the command and control structure, the particular interest of the framework nation should be addressed as the main factor. The strategic direction and political control of this type of operation would be exercised by the Political and Security Committee.

In this context, it would be effective to make better use of existing multinational initiatives at the European level, such as the Multinational Land Force, the Weimar Battlegroup, the Visegrad Battlegroup, and the Nordic Battlegroup, just to mention the main ones. ${ }^{12}$ Member states involved in these initiatives could act as a "framework nation" — actually a group of nations - able to pool military assets and share responsibilities, ready to address a specific crisis on behalf of the European Union. This includes also, in a comprehensive way, more politically oriented initiatives, such as the $5+5$ Defense Initiative for 
enhancing military/civilian coordination within the Mediterranean theater. ${ }^{13}$ The 5+5 Defense Initiative brings together five countries on the southern side of the Mediterranean (Algeria, Libya, Mauritania, Morocco, and Tunisia) and five countries on the northern side (France, Italy, Malta, Portugal, and Spain).

The overall objective of this approach is to promote the execution of military operations in a sustainable, prompt, and effective way, enabling European nations to substantially contribute to international security and thereby to the EU's role as a global security actor. The underlying idea of this article is that those nations that have a broad capability spectrum and have specific concerns over a given crisis could act as framework nations to provide an operational framework for cooperation with other concerned EU partners.

\section{Conclusions}

The president of the European Commission, Jean-Claude Juncker, has recently stressed in his 2017 State of the Union speech the need for "a Europe that protects, a Europe that empowers, a Europe that defends." ${ }^{14}$ The president is definitively calling for the EU member states to take greater responsibility for the security of European citizens. The security and protection from internal and external threats will be possible through the development of key defense capabilities able to deter, respond, and protect. The acquisition of such capabilities, and more generally of a defense system, will require an adequate superstructure able to employ them.

The proposed organizational changes to improve the planning and conduct of Common Security and Defense Policy interventions will allow the EU to better manage its commitment in crisis prevention and management, thus increasing its role as a global security actor. Furthermore, the proposed changes are optimized for the conduct of missions in which the military component is integrated with civil and police components into a single mission. The new organization will still retain an ability to separate the management of civilian missions and military operations while also providing an integrated component for managing aspects that are common to both types of intervention. Furthermore, it is optimized for the type of military operations provided by the Lisbon Treaty. In respect to the direction of missions and operations, it combines civilian capabilities with an appropriate structure to ensure delivery of all the functions needed to plan and conduct military operations (J1-J9). ${ }^{15}$ In addition, this will facilitate linkages between all EU organizations involved in crisis prevention and management to achieve a fully multilateral response capability.

Together with the improvement of the EU's rapid reaction capability, the proposed reorganization would allow for better sharing of resources and for more equitable burden sharing between EU countries, requiring the partici- 
pation of all countries in the direction of operations/missions. Both proposals would also avoid any duplication of already existing international structures in the area of security, providing the EU with an efficient structure that complements both NATO and the UN in the sectors of peace and security.

\section{Notes}

1. Shared Vision, Common Action: A Stronger Europe: A Global Strategy for the European Union's Foreign and Security Policy (Brussels: European External Action Service, 2016).

2. "EUROSTAT Statistics Explained," EUROSTAT, 20 July 2017. European countries import the bulk of natural gases for their consumption. The main exporters of natural gases in Europe are Norway (29 percent), Russia (18.3 percent), and Ukraine (17.1 percent). It is obvious that a crisis among the second and third major exporters had severe repercussions for European countries, especially in terms of rising costs.

3. Other than economic reasons, it was a political choice of the EU member states to turn to the so-called soft power as the principal means of EU foreign policy, as explained masterfully in Nick Witney, How to Stop the Demilitarisation of Europe?, ECFR Policy Brief no. 40 (London: European Council on Foreign Relations, 2011).

4. Reflection Paper on the Future of European Defence (Brussels: European Commission, 2017).

5. U.S. secretary of defense Robert M. Gates, "The Security and Defense Agenda (Future of NATO)" (speech, Brussels, Belgium, 10 June 2011).

6. Currently, five EU operational headquarters exist within national frameworks in France, Germany, Greece, Italy, and the UK (future availability will depend on the agreement about Brexit), in addition to SHAPE as envisaged with Berlin Plus agreements and the EU's Operation Centre located in the EU Military Staff in Brussels.

7. The European Union Military Committee is the highest military body within the European Council. It provides military advice and recommendations to the Political and Security Committee (PSC), as well as military direction to the EU Military Staff.

8. And/or other geographical areas where there are more than one Common Security and Defense Policy missions or operations active, following the ongoing discussion about the future of the activated operations center.

9. Eva Gross, Assessing the EU's Approach to Security Sector Reform (SSR) (Brussels: European Union, 2013). This study explains that "SSR activities are key for stabilizing fragile and post-conflict states through their emphasis on training, institutional reform and governance."

10. This time horizon refers to the contribution of individual member states to the EU Battlegroup, meaning that at each Force Generation Conference they have to establish their own contribution for the next five years.

11. Council Decision 2011/871/CFSP of 14 May 2007 established a mechanism to administer the financing of the common costs of EU operations having military or defense implications (Athena).

12. The multinational land force is a multinational formation including Hungary and Slovenia. It is constituted on the base of the Italian "Julia" Alpine Brigade, integrated by a battalion for each nation. It receives orders by a military-political committee of three nations. The multinational land force can be employed by one of the following international organizations: NATO, UN, EU, and the Organization for Security and Cooperation in Europe (OSCE). "Multinational Land Force," Ministry of Defence, Italian Army. The Weimar Battlegroup is a multinational EU Battlegroup under Polish leadership, in which Germany and France also participate as members of the Weimar Triangle. See Marcel Dickow et al., Weimar Defence Cooperation—Projects to Respond to the European Imperative, FG03-WP No 6 (Berlin: German Institute for International Security and Affairs, 2011). The Visegrád Battlegroup or V4 EU Battlegroup is an EU Battlegroup led by Poland, in which the other Visegrád Group countries- the Czech Republic, Slovakia, and Hungary—participate. For the Visegrád Group, see Wojciech 
Lorenz, "EU Battle Group: A Chance for a Breakthrough in Visegrad 4 Cooperation," Polish Institute of International Affairs Bulletin 39, no. 492 (16 April 2013). The Nordic Battlegroup is a multinational EU Battlegroup led by Sweden with contingents from Estonia, Finland, Ireland, Latvia, Lithuania, and Norway. See Jan Joel Andersson, "If Not Now, When?: The Nordic EU Battlegroup," Issue Alert, no. 11 (February 2015).

13. The " $5+5$ Defence Initiative" is the defense part of the " $5+5$ Dialogue," which brings together five countries on the southern side of the Mediterranean (Algeria, Libya, Mauritania, Morocco, and Tunisia) and five countries on the northern side (France, Italy, Malta, Portugal, and Spain).

14. "President Jean-Claude Juncker's State of the Union Address 2017" (speech, Brussels, Belgium, 13 September 2017).

15. The "J" stands for "Joint" and it refers to the kind of organization, while the numbers from 1 to 9 are associated with different military branches (J1 is the personnel branch, $\mathrm{J} 2$ intelligence, J3 operations, J4 logistic, J5 plans, J6 communications, J7 training, J8 administration, J9 civil-military cooperation). 


\title{
Pushing the Limits of Range Long-range Amphibious Operations
}

\author{
Steven Yeadon
}

\begin{abstract}
The Marine Corps Operating Concept states that a Marine Air-Ground Task Force composited to defeat a near-peer competitor with antiaccess/area denial (A2/AD) capabilities may demand more emphasis on the air combat element. This analysis goes well beyond the current doctrine for amphibious operations by proposing a future military concept termed long-range amphibious operations, or operations that rely almost exclusively on an air combat element, and the possible long-range deployment of surface connectors for ship-to-shore movement. Such amphibious operations may hold promise for overcoming A2/ $\mathrm{AD}$ capabilities while providing new capabilities along the range of military operations and support of American long-term strategic interests. This analysis provides a rare attempt to systematically examine the strengths, weaknesses, technological capabilities, and characteristics of such long-range operations to understand the current promise and perils of long-range amphibious operations, evaluating what acquisitions will best support such amphibious operations, and incentivizing constructive discussion concerning doctrinal innovation in relation to amphibious operations.
\end{abstract}

Keywords: amphibious operation, amphibious warfare, forcible entry, air combat element, amphibious equipment, air assault, near-peer competitor

his analysis assesses the technological capabilities, limitations, and vul-
nerabilities of long-range amphibious operations through the year 2028,
when the procurement of medium- and ultra-size future vertical take-

Steven Yeadon is an independent scholar holding a bachelor of arts in political science from the University of Central Florida. He is currently preparing for a graduate education in strategy.

MCU Journal vol. 9 , no. 2

Fall 2018

www.usmcu.edu/mcupress 
off and landing (VTOL) aircraft begins. Long-range amphibious operations are defined as operations that seek to keep amphibious ships 100 nautical miles $(\mathrm{nm})$ or more from the amphibious objective area. This is a distance that allows for multi-layered defense against anitship cruise missles that can include the use of long-range interceptors, such as the Standard Missle 2 and Standard Missle 3, while relying more on medium-range engagements than long-range missions for defense-an idea proposed by the Center for Strategic and Budgetary Assessments (CSBA). ${ }^{1}$ Thus, this article explores a future military concept that concentrates on potential forces and their possible capabilities. That said, this article will not go into the utility and feasibility of amphibious operations themselves, assuming such operations are an important tool to have for commanders and policy makers.

After an explanation of the threats in a contested amphibious landing, it will be shown that for long-range amphibious operations using the Sikorsky CH-53K King Stallion, it is feasible to use an air combat element to transport, provide fire support for, and provide air resupply for Marines. This would include the use of batteries of the M777A2 (a $155 \mathrm{~mm}$ howitzer towed artillery); a light armored vehicle (LAV) variant, the M142 High Mobility Artillery Rocket System (HIMARS); the Oshkosh Defense Joint Light Tactical Vehicle (JLTV); and the AM General High Mobility Multipurpose Wheeled Vehicle (HMMWV or humvee), which could be used in an air assault from an Expeditionary Strike Group (ESG) or Marine Expeditionary Brigade (MEB) assault amphibious task force up to $110 \mathrm{~nm}$ from shore. However, this analysis will show that such operations carry their own limitations because of the loss of M1A1 Abrams main battle tanks, amphibious assault vehicles (AAVs), heavy logistic support, and naval gunfire support (NGFS).

This analysis will then assess long-range amphibious operations by the capabilities that may be deployed through 2028. It will be shown that to optimize future long-range operations, drastically increase their radius of action, and increase the weight of equipment transported by VTOL aircraft, the U.S. Marine Corps will need to acquire Marine attack tiltrotors, utility tiltrotors, and ultra-heavy VTOL aircraft. An assessment of the strategic advantages and disadvantages of this type of warfare will follow. This will culminate in a series of acquisition recommendations for the U.S. Navy and the Marine Corps to enhance long-range amphibious operation capabilities.

The ultimate purpose of this article is to analyze the feasibility and effectiveness of future long-range amphibious operations in the execution of U.S. strategic interests. This military concept will need to be tried and tested by strategists and commanders long before they can be used in simulations and wargames. Ultimately, the goal of the study of this military doctrine will be to one day in- 
fluence new doctrine for the benefit of troops that face the challenge of defeating enemy militaries armed with antiaccess/area denial (A2/AD) technologies.

\section{Knowing the Challenges of a Contested Amphibious Operation}

First, it is important to explain the challenges that will be presented in an amphibious operation against contested coastline. An analysis from Rand explains the dangers associated with amphibious operations in contested areas, which explains the advantages and disadvantages inherent in the use of amphibious forces in contested littoral combat zones:

Antiship missiles and tactical aircraft. Potential enemies can detect an Amphibious Task Force (ATF) over-the-horizon (OTH) as well as deploying tactical aircraft and launching a large number of antiship missiles. Although the ships of an ATF have several options for missile defense, including point defense, area missile defense, and defensive counterair, the closer the ships of the ATF come to shore, the less effective these defenses become. This is because it is easier to detect an ATF the closer it is to shore, because the reaction time of an ATF to aircraft and missiles decreases the closer to shore it is, and because the number of weapons an enemy may use increases the closer to shore an ATF comes. These same issues are also true of ships performing naval surface fire support for the ATF.

\section{Submarines operating in both the open ocean and littoral waters.}

Enemy nuclear submarines can threaten the ships of an ATF as it transits to the battle zone. The ATF may be most vulnerable during this period. As seen in the 1982 Falkland Islands War, Argentine attacks using fixed-wing aircraft armed with Exocet missiles managed to sink one ship of a British ATF. However, the damage was not sufficient to stop the ATF from performing an amphibious operation. ${ }^{2}$ Lower-speed diesel submarines cannot threaten as wide an area, but they are very difficult to detect. Diesel submarines are a significant threat to an ATF and ships providing naval surface fire support during an amphibious operation.

Mines laid in approaches, in shallow water, and in the surf zone. As the easiest way to stop an amphibious assault, mines can threaten amphibious shipping, surface connectors carrying the larger and heavier elements of the assault force, and the landing force equipment and personnel as they move ashore. Mines represent a way for less advanced forces to limit the amphibious capabilities of more advanced navies. This is evident in the First Gulf War (1990-91) with the decision not to carry out an amphibious assault by Ma- 
rines, and in the failure to prosecute an amphibious assault in the Korean War at Wonsan (1950). ${ }^{3}$

Air defenses, ranging from sophisticated integrated air defense systems to short-range, shoulder-fired weapons and small arms. These are principally a threat to transport and support aircraft, but they may be used against fire support elements.

\section{Opposing forces ashore who directly oppose the movements of the} landing force. Even if there is relatively light opposition to movement ashore, adversary land forces can pose significant opposition to the landing force once it arrives. ${ }^{4}$

\section{Technological and Logistical Assumptions and Challenges Pertaining to Near-Term, Long-range Amphibious Operations}

For the near future of the next five years, the following factors limit the range, weapons, and capabilities of long-range amphibious operations and the effectiveness of American strategic interests. A carrier strike group (CSG) or multiple CSGs will likely be required for a long-range amphibious operations due to the need to control the airspace over contested coastline being invaded, to suppress coastal antiair defenses, and to provide considerable close air support to the ground maneuver element. There are also limitations related to the range of the aircraft used. The combat radius of a Bell Boeing MV-22B Osprey is $428 \mathrm{~nm}$ when transporting 24 Marines and a ramp-mounted weapon system. ${ }^{5}$ However, the loiter time of an Osprey is only 20 minutes when traveling 428 nm. ${ }^{6}$ This means the aircraft will have little time before needing to head back to an ATF to refuel. Further limitations of the Osprey include its ability to transport external loads $428 \mathrm{~nm}$ or to transport internal loads $428 \mathrm{~nm}$ unless they are 6,000 pounds or lighter. ${ }^{7}$ Six thousand pounds is not even enough to transport the M1161 Growler internally transportable vehicle (ITV). ${ }^{8}$ If transporting an ITV, the combat radius of the Osprey falls to as few as $220 \mathrm{~nm} .^{9}$

Furthermore, in an amphibious operation that attempts to take full advantage of the combat radius of an Osprey, troops will need to create landing zones to gain access to logistical supplies flown in by the aircraft. The Osprey also has a combat radius of only $50 \mathrm{~nm}$ if carrying a 10,000-pound external load. ${ }^{10}$ Other aircraft have similar issues related to range and load-bearing capacity. The combat radius of the Boeing F/A-18E/F Super Hornet is only $390 \mathrm{~nm}$ when armed with two AIM-9X Sidewinder missiles and 4,000 pounds of bombs for interdiction missions. ${ }^{11}$ In addition, this aircraft is the current backbone of U.S. Navy carrier air wings. ${ }^{12}$ There are additional issues related to range. Long-range 
amphibious operations operating more than $100 \mathrm{~nm}$ away from an ATF will demand a heavy reliance on aircraft for fire support. While the Lockheed Martin F-35B/C Lightning II aircraft have a greater combat radius than the Super Hornet fixed-wing aircraft, the Lightning IIs are not the backbone of U.S. Navy carrier battle groups. ${ }^{13}$ In addition, the number of F-35Bs on amphibious assault ships will be limited to maximize the number of transport aircraft.

The new CH-53K King Stallion can transport equipment or vehicles that weigh 27,000 pounds farther than $110 \mathrm{~nm}$ in high-altitude or hot environment conditions. ${ }^{14}$ This allows King Stallions to transport one HIMARS, one LAV variant, one JLTV, two humvees, one M777A2 howitzer towed artillery with room for projectiles, or two 10,000-pound cargo pallets. ${ }^{15}$ Although its combat radius of $110 \mathrm{~nm}$ is extraordinary, it is one of the biggest restrictions for longrange amphibious operations. Fire support from VTOL aircraft are limited to $119 \mathrm{~nm}$, which is the combat radius of the Bell UH-1Y Venom utility helicopter. While the Bell AH-1Z Viper attack helicopter has a wider combat radius of $131 \mathrm{~nm}$, for both the Venom and Viper aircraft to work in tandem, the range is more limited. ${ }^{16}$

To begin an assessment of these facts, we must first fix an outer range of an amphibious assault using Ospreys. Four hundred and twenty-eight nautical miles is simply too far for an amphibious landing force composed entirely of infantry to seize territory. The combat radius of Super Hornet aircraft prevents this because the landing force will be entirely reliant on fixed-wing aircraft for fire support and for deep strikes against enemy reinforcements that threaten the amphibious objective area. Due to the need for significant close-air support, $390 \mathrm{~nm}$ (448 statute miles) is the maximum range of an amphibious assault with lightly armed forces. ${ }^{17}$ Even then, deep strikes against enemy reinforcements will not be possible.

Thus, the longest-range amphibious assault of lightly armed forces will likely be less than $390 \mathrm{~nm}$ from an ATF. Even then, significant numbers of strike aircraft will be needed, because less than one-third of all aircraft would be in the amphibious objective area to provide fire support, based on the general rule that an aircraft needs one-third of its fuel to conduct operations when it travels its maximum combat radius. ${ }^{18}$ If the Marines desire ITVs, the range of the amphibious operation will be reduced to as little as $220 \mathrm{~nm}$. In addition, the Marines will be reliant on Osprey carrying internal cargo of 6,000-8,300 pounds, which will result in a need for landing zones for air resupply. Medevac (medical evacuation) will also be an issue since it may take more than an hour to fly wounded soldiers back to a hospital aboard a ship, given the Osprey has a maximum cruise speed of 270 knots. ${ }^{19}$ It will also be difficult to quickly mass aircraft at such long ranges, because many aircraft will be in transit to the amphibious objective area, in transit to the ATF, or refueling and rearming. 
Realistically, we are discussing more of a raider or reconnaissance force than an actual amphibious assault to seize territory, especially when fighting for contested coastline. Another use for such operations are extreme longrange capabilities for amphibious withdrawals, such as during a noncombatant evacuation and for humanitarian aid. That said, such long-range operations also present valuable capabilities in conflicts against lightly armed foes where infantry and ITVs may be sufficient for an operation's objectives. For example, the seizure of Afghanistan's Kandahar Airfield by Naval Task Force 58 using lightly armed forces 350 statute miles from an ATF. ${ }^{20}$ In addition, a lightly armed force of only infantry and ITVs, working at extreme ranges, may be sufficient for preassault raids, feints, other forms of military deception, pre-assault raids, and for accomplishing some of the objectives of a broader amphibious assault. In addition, by deploying aircraft from hundreds of nautical miles from shore, the ATF gains the ability to conduct amphibious operations from blue-water ocean outside of a state's exclusive economic zone. This will increase the likelihood that an ATF remains undetected, which increases the surprise and initiative of an ATF's amphibious operations. This freedom of maneuver may give an ATF the option to operate close to allied military bases and expeditionary advanced bases. This provides the opportunity for an ATF to stay within reach of friendly, land-based antiship weapons and aircraft. Two hundred nautical miles also allows for a better defense against antiship cruise missles, because it allows for more long-range engagements using long-range interceptors. This allows for current missle defense tactics to be used, as opposed to proposed tactics.

Beyond $131 \mathrm{~nm}$, there will be no attack aircraft escort for the Ospreys. This likely prevents forcible entry operations against a defended coastline. Furthermore, a lightly armed force of only infantry and ITVs may be overwhelmed by enemy armored forces, as was a problem in World War II for airborne infantry. For example, during Operation Market Garden at the Battle of Arnhem in the Netherlands, in which lightly armed British soldiers failed to hold their objective against German armored units, which overwhelmed them. ${ }^{21}$

In the near future, a more realistic range of an actual amphibious assault over a long range to seize contested coastline would be $110 \mathrm{~nm}$. This would provide Marines an air assault combining LAVs, towed artillery, HIMARS, JLTVs, "up armored" humvees, and both utility and attack VTOL aircraft, while being well within the combat radius of carrier-based, fixed-wing aircraft and allowing for Ospreys to loiter longer. This is significantly more firepower compared to a reliance on only carrier-based, fixed-wing aircraft and lightly armed forces.

As for the land warfare capabilities of such a landing force, light armored reconnaissance units armed with LAV variants possess mobility, firepower, and security, which are "best employed not as a substitute for infantry and armor in 
the attack or defense, but to perform reconnaissance and security missions that allow armor and/or infantry to close with the enemy decisively." ${ }^{2}$

Thus, LAVs are no substitute for heavier armored vehicles, such as main battle tanks. This means that Marines will achieve decisive victory over an opponent in long-range amphibious operations through infantry deployed from VTOL aircraft in an air assault. The landing force will be able to deploy powerful artillery assets to aid Marines on foot in long-range amphibious operations. HIMARS, M777A2 towed artillery batteries, and various types of mortars will give significant fire support to Marines beyond that provided by VTOL and fixed-wing aircraft. In addition, LAVs and humvees offer Marines ambulances, electronic warfare capabilities, a vehicle that can carry logistical supplies and other equipment, or significant mobile firepower to infantry units. However, there will not be enough humvees or JLTVs to provide rapid transportation for Marine units on foot. To give mobility to Marine fireteams will require Growler ITVs, since they can fly on Ospreys, because they are, typically, far more numerous than King Stallions in an air combat element. Even then, these unarmored vehicles are so heavy that the Osprey will only be capable of transporting one ITV and a Marine fireteam using it, which is one-sixth of the Marines carried if all troops are foot mobile. Regardless, this means that Marines will lack the protected, mobile firepower they now possess in amphibious operations that use AAVs.

A chief problem for Marines will be defeating enemy armored vehicles, which near-peer competitors possess by the hundreds if not thousands. Against such enemy forces, Marines will have to rely on man-portable antitank weapons and fire support from artillery, VTOL aircraft, and fixed-wing aircraft. Another major concern is that Marines will be dependent on towed as opposed to self-propelled artillery. Radar can detect artillery and trace it back to its source, which allows for counterbattery fires. ${ }^{23}$

This means that the Corps' current efforts to modernize artillery and develop active countermeasures to rockets, artillery, mortars, guided missiles, and ballistic missiles may have an enormous impact on future long-range amphibious operations and our long-term strategic efforts. For example, the procurement of lightweight, self-propelled artillery that is King Stallion transportable will offer extraordinary capabilities to long-range amphibious operations. Despite these drawbacks, such long-range amphibious operations may be a useful tool against enemies with significant coastal defenses but a low number of main battle tanks or other heavy-armored vehicles in the amphibious objective area. In summation, the quality and capabilities of Marines on foot and the lightweight forces and aircraft supporting them determine the effectiveness of longrange amphibious operations.

However, one key consideration will hamper efforts to deploy forces so far 
from amphibious ships — the varied speeds of aircraft. Osprey will embark and disembark troops and internal cargo far faster than helicopters, given their varied cruising speeds. Thus, to have armed escorts, Ospreys will have to fly slower than originally designed, which will be less fuel efficient and may be unsafe due to stalling speeds. These differing cruising speeds also may present problems of coordination for command and control.

That said, even at $110 \mathrm{~nm}$, the ATF may be within a nation's exclusive economic zone, which may risk detection from a wide variety of civilian and military vessels. This could end in a naval battle using antiship cruise missiles, antiship ballistic missiles, and hypersonic missiles. Upon detection of an ATF, an alerted enemy may redeploy forces, including surface-to-air missiles, to combat an amphibious landing. To highlight how dangerous a rapid response by a defender is to a detected landing force, the Dieppe raid in France during World War II is an excellent example. Even without precision-guided weapons and modern vehicles, it took German defenders only 15 minutes to mass their forces between a first wave of Allied infantry and a second wave of Allied tanks. Even additional infantry landing, flanking the Germans in tandem with the second wave of tanks, was not enough to dislodge the German defenders. The rapid response by German forces and terrain that benefited the defenders were the death knell of the operation, which ended in 60 percent losses. ${ }^{24}$

In contrast, even if detected, the ATF in a long-range amphibious operation will have increased response time to, and layers of defense against, missile attacks and a reduced likelihood of mine attacks. They will also have the range to pick and choose where to land forces across a long coastline, even while under attack. This will allow commanders to mass landing forces where the enemy is weakest, even against an enemy alerted to the presence of the ATF. The shear amount of coastline that is threatened by an ATF with such reach will also enhance deception operations. Defenders responding to deception operations may mass their forces in the wrong locations and, due to the size of the area of operations, lack the ability to rapidly redeploy their forces to other locations, creating weak points that a commander can exploit.

\section{Heavy Armor and Long-Range Amphibious Operations}

A problem with long-range amphibious operations, in general, is that the amphibious operation depends primarily on infantry, since the operation will lack heavier equipment such as M1A1 Abrams main battle tanks, AAVs, and heavy logistic support. Simply put, there remains no technological options for transporting main battle tanks by VTOL aircraft, even within the next 15 years.

Thus, if it is determined that an amphibious operation requires main battle tanks, that infantry transport on armored personnel carriers such as AAVs, or that there is a need for heavy logistic support, then transport by surface is the 
only option. To do this, part of the ATF equipped with well decks will need to either do one of two things. First, they can come closer to shore than $100 \mathrm{~nm}$, with the goal of carrying out an over-the-horizon amphibious operation using surface connectors. However, if the ATF is detected, then such an operation will be very risky to the amphibious ships and for all landing craft involved, especially given the slow speed of landing craft, utilities (LCUs) at 8-11 knots and the very slow speed of AAVs at 6 knots. ${ }^{25}$ These are speeds that will demand that amphibious ships come very close to shore, possibly $24 \mathrm{~nm}$ or less to deploy landing craft. At $24 \mathrm{~nm}$ to shore, antiship cruise missiles and hypersonic missiles will allow very little time to react. For hypersonic missiles, troops will have at most 24 seconds to react. Landing vehicles also will face great risk from precision-guided weapons, given their slow speed and hours-long transit time. Mines and obstacles also could present severe problems for slow landing vehicles. Second, they could deploy ship-to-shore connectors and landing craft, air-cushions (LCACs) approximately 100 nautical miles from shore to transport a limited number of AAVs, main battle tanks, and heavy logistic support to shore. This distance is due to the range of hovercrafts, which for the earlier LCAC is 250 statute miles with a 60-ton payload. ${ }^{26}$ Another issue is that only ship-to-shore connectors are normally designed to carry an Abrams tank between the two hovercrafts. ${ }^{27}$ There is also the problem that a limited number of tanks and AAVs may be insufficient to push onto the objective. Although, if the amphibious force was composited with all its surface connectors being ship-toshore connector hovercraft, then it is possible to transport a substantial number of Abrams main battle tanks to shore in one lift. However, hovercraft will spend around three hours traveling to shore, which will leave them open to attacks by precision-guided weapons if they lose the element of surprise. Last, mines will still hold some threat even for hovercrafts, which are less susceptible to them. ${ }^{28}$

Additionally, the goal of including a large number of armored vehicles immediately changes the strategic tenor of the amphibious operation. The security of the amphibious ships coming closer to shore will be less than for the rest of the ATF, which can stay farther from the coastline that they attack. There may be a lack of security for slow amphibious landing vehicles against modern defenses, especially in an antiaccess environment. Slow landing vehicles, such as LCUs and AAVs, would risk being tracked and attacked before ever making it to shore, especially if they must deploy many nautical miles from shore for increased security for their fleet. A fleet of amphibious ships and their escort coming relatively close to contested shoreline for a surface deployment of armored vehicles defeats the primary purposes of long-range amphibious operations. It sacrifices maneuver space from the sea, it makes the ships carrying out the amphibious operation far more vulnerable, it hampers the ability of the landing forces to concentrate strength where the enemy is weakest, it may drastically 
reduce the statute miles of coastline threatened by an ATF in a 24-hour period, a fleet of ships coming closer to shore have a far greater risk of detection, and it potentially reduces the surprise and initiative of the amphibious operation. Finally, the amphibious ships traveling closer to shore, most likely San Antonio-class ships and LPD Flight II-class ships, are expensive, important vessels that cannot be easily risked. The loss of even a few of them could be a major blow to the U.S. Navy and its amphibious operations for years.

However, there are benefits to placing several amphibious ships closer to shore. It would allow the air combat element to more swiftly refuel, rearm, and embark troops and cargo. This would increase the tempo of the operation, thus allowing for more troops, weapons, and logistical supplies to be transported during one period of nautical twilight. This could also positively impact the initiative of the amphibious operation and reduce the number of VTOL aircraft necessary to provide the same level of both air resupply and aerial fire support. Positioning amphibious ships closer to shore would also allow the possibility of using Osprey for heavy external lift. Yet, there remains considerable risk the closer to shore amphibious ships must come.

\section{Naval Gunfire Support and Long-Range Amphibious Operations}

A major problem for long-range amphibious operations, in general, is that until aircraft deliver and deploy M777A2 towed artillery and HIMARS, the landing force will not have any fire support except for VTOL aircraft, man-portable mortars, and close-air support provided by fixed-wing aircraft. It will notably be missing naval gunfire support (NGFS), unless ships with naval guns are sent very close to contested shoreline, which makes them extremely vulnerable to antiship cruise missiles, antiship ballistic missiles, hypersonic missiles, mines, and possibly even small arms.

Ships must come close to the shore due to the range of their artillery. The 5-inch/54 caliber (Mk45) lightweight gun, which large surface combatants are armed with, only has a maximum range of $13 \mathrm{~nm} .{ }^{29}$ This means that for an Mk45 gun to fire inland several statute miles, the ship using the weapon must come within a few nautical miles of shore, possibly within range of small arms. Thus, the risk to large surface combatants providing NGFS is high. Large surface combatants also excel at multiple missions, and they are expensive ships whose loss would be felt for years. This begs the question: Why risk a destroyer or cruiser on NGFS? That said, finding a way to provide NGFS farther from shore has been a hurdle for the U.S. Navy.

First, the Zumwalt-class destroyer, which were designed for land attack, will stop construction after three ships. ${ }^{30}$ One reason for the cancellation of these vessels is a lack of ammunition for the advanced gun system (AGS). ${ }^{31}$ The reason 
for the ammunition shortage for the AGS is because the cost per round for their unique ammunition has climbed to $\$ 800,000$ to $\$ 1$ million per projectile. ${ }^{32}$ This is due to the production of so few rounds, because only six AGSs exist. The U.S. Navy very sensibly opted not to purchase more ammunition for the AGS. ${ }^{33}$ Yet, the AGS was originally designed to have the ability to fire artillery rounds up to $83 \mathrm{~nm}$ instead of $13 \mathrm{~nm}$, a valuable NGFS capability for an overthe-horizon, or long-range, amphibious operation. ${ }^{34}$ This means that a weapon meant to provide over-ther-horizon NGFS is now useless. Thus, $155 \mathrm{~mm}$ naval artillery will not soon supplant 5-inch guns in amphibious operations.

Second, the electromagnetic railgun (EMRG) is years away from implementation on naval ships. ${ }^{35}$ In addition, only the Zumwalt-class ships currently provide the power generation capability to use the weapon. ${ }^{36}$ It is hoped battery packs may allow the weapon to function on naval vessels other than the Zumwalt class, but, nevertheless, there remains no easy solution to the problem of putting such weapons on the Arleigh Burke-class of guided missile destroyers. ${ }^{37}$ Thus, it is unlikely that the EMRG will revolutionize NGFS until the deployment of the proposed future surface combatant destroyers.

Finally, this currently leaves only one technological solution to the dilemma of NGFS within the next 10-15 years: the use of either Excalibur N5 projectiles or hypervelocity projectiles (HVPs) for Mk45 guns. The longer-range HVPs will be able to fire up to $40 \mathrm{~nm}$ at a cost of $\$ 25,000-\$ 50,000$ per projectile. ${ }^{38}$ However, this still requires that a fleet composed of several large surface combatants capable of missile defense will be relatively close to shore to provide NGFS. Such ships would exclusively use HVPs to stay 20-30 nm from shore.

This solution has significant problems. First, a fleet of large surface combatants coming relatively close to contested shoreline to provide NGFS partially defeats the primary purposes of long-range amphibious operations. It makes the ships far more vulnerable, and a fleet of ships closer to shore have a far greater risk of detection, which potentially reduces the surprise and initiative of the amphibious operation. Mines also become a much larger issue closer to shore, and even at $30 \mathrm{~nm}$ from shore, the time to react to a hypersonic missile launched from the coast would be around 30 seconds or less. There also will be far less time to react to antiship cruise missiles and hypersonic missiles. Thus, the security of the fleet providing NGFS will be substantially less than for the rest of the ATF. Large surface combatants are expensive, strategically important vessels that cannot be easily risked and serve as multimission vessels, whose other strengths are mitigated in the role of NGFS for an amphibious operation. Last, HVP ammunition is expensive. If 5-inch guns must use them exclusively, this means that the NGFS will add considerable expense to amphibious operations. Assuming the fleet providing NGFS fires a conservative estimate of 1,800 projectiles, which is the equivalent of 18 towed artillery teams firing 100 pro- 
jectiles each, then the cost of the projectiles alone would be between $\$ 45$ and $\$ 90$ million. All of this means that there are simply no easy ways of bringing NGFS to bear for troops deploying from $100 \mathrm{~nm}$ or more from shore unless considerable risk is taken.

The current course by the U.S. Navy leaves in doubt what the near future of NGFS will be in an evolving threat environment demanding amphibious operations far from shore. The limitations of NGFS also may threaten the ability of Marines to land from long range with adequate fire support. In addition, the current future of NGFS seems to be the deployment of a considerable number of future surface combatant destroyers armed with electromagnetic rail guns. However, this is a long-term plan for NGFS over the course of decades and may make NGFS less than adequate in near-future threat environments. Thus, what is needed is a long-range interim naval gun that can be installed on current large surface combatants, whose lifetime will stretch on for decades. A new naval gun could increase the range of NGFS, and thus provide increased security for any fleet of large surface combatants that must venture close to shore.

\section{Technological and Logistical Assumptions and Challenges for Future Long-Range Amphibious Operations}

The remainder of this analysis will deviate from near-future capabilities and examine what the future of long-range amphibious operations could be through 2028. Starting in 2028, it may be possible for long-range amphibious assaults to more than double their radius of action once procurement of medium- and ultra-size FVL aircraft begins. At that time, the following factors will limit the range, weapons, and capabilities of long-range amphibious operations.

The Bell V-280 Valor utility aircraft is marketed as capable of a cruising speed of 280 knots, a minimum combat range of $500 \mathrm{~nm}$, and an external cargo capacity of up to 10,500 pounds or 14 troops. ${ }^{39}$ However, 150 knots is the maximum safe speed a current sling load, which carries equipment underneath a VTOL aircraft using cables, can travel. ${ }^{40}$ If the marketed capabilities of the Valor are accurate, then it makes possible the transportation of M777A2 towed artillery, which weigh less than 10,000 pounds, more than twice the range of a King Stallion. The Valor could also allow for the transportation of pallets of external cargo for air resupply more than twice as far as a King Stallion. ${ }^{41}$ For instance, one Valor could transport a single M777A2 towed artillery almost half its minimum combat range, around 200 or more nautical miles; one aircraft could transport the eight crew for the weapon; and one aircraft could externally transport 10,500 pounds of artillery projectiles for the weapon through a sling load. It would take three pallets weighing 14 pounds each to transport 10,458 pounds of external cargo. ${ }^{42}$ This amounts to 110 high explosive projectiles 
weighing 95 pounds each. ${ }^{43}$ Thus, it will take at minimum of 18 Valor utility aircraft to deploy a battery of six M777A2 artillery with 110 projectiles each. Of course, artillery resupply for HIMARS and towed artillery will be weight intensive, and there could be a need for thousands of projectiles to take key objectives; for example, consider the 1982 assault by British Commandos on Mount Harriet in the Falkland Islands War, which required 3,000 artillery rounds. ${ }^{44}$ HIMARS will need to be supplied by air with launch boxes that contain rockets and missles. There also will be a lack of artillery resupply vehicles for both M777A2 and HIMARS artillery. In addition, setting up $155 \mathrm{~mm}$ towed artillery will require that troops create a firing position for the artillery to occupy.

It will take 80 minutes for the Valors to reach an amphibious objective area $200 \mathrm{~nm}$ away at 150 knots. The tiltrotors will then disembark their external cargo and travel 43 minutes back to the ATF at a cruising speed of 280 knots, where they quickly refuel, embark more cargo, and repeat this sequence. Given this scenario, it may take the Valors more than six hours to complete two external lifts. Ospreys will be well within their combat radius at a range of $200 \mathrm{~nm}$ from an ATF, which will give them more time to loiter or the capability to take troops to a second objective. At a maximum cruising speed of 270 knots, Osprey may be able to complete two or even three lifts to an amphibious objective area $200 \mathrm{~nm}$ away in an eight-hour period of nautical twilight.

Large numbers of Valors and Ospreys will be required to transport a maximum number of troops, weapons, and logistical supplies within one period of nautical twilight. Long-range amphibious operations will require an attack VTOL aircraft capable of greater combat radius than the AH-1Z Viper. Such necessary specifications will likely require an attack variant of the Valor tiltrotor. The speed of the Valor attack aircraft present opportunities for forcible entry by allowing Ospreys to be escorted to their objective at their maximum cruising speed. It may be possible to transport armored vehicles or logistical vehicles weighing 41,000 or more pounds hundreds, if not thousands, of nautical miles in 2025 using naval VTOL aircraft adapted from the future vertical lift competition for ultra-heavy VTOL aircraft. The goal of the competition is to field a VTOL aircraft in 2025 with capabilities somewhere between those of the Lockheed Martin C-130J Super Hercules and the Airbus A400M Atlas. ${ }^{45}$ Such aircraft could conceivably transport medium-armored vehicles of the Stryker family of vehicles and, possibly, the BAE Systems Amphibious Combat Vehicle 1.1. This could add substantial firepower to a landing force operating at long range while providing mobile protection for some units of Marines, which would give commanders greater flexibility to respond to the enemy.

Nevertheless, it would be very difficult, if not impossible, to operate such large future vertical lift ultra-heavy VTOL aircraft from an amphibious assault ship due to limited flight deck space. However, given the desired range of ultra- 
heavy VTOL naval aircraft, they can deploy from military bases in the region of the amphibious operation with the support of aerial refueling. The range of such aircraft gives them the ability to deploy from the continental United States, avoiding the need for stationing such large aircraft on amphibious ships. That said, there would still be great utility if such large VTOL aircraft could land on the flight deck of an amphibious assault ship, allowing them to embark vehicles and then quickly travel back to the amphibious objective area. Alternatively, if such aircraft could not land on amphibious assault ships, multiple waves of such aircraft could deploy from military bases in the region to disembark forces in tandem with the aircraft of an ATF. Another possible option would be to land such large VTOL aircraft on an aircraft carrier supporting the amphibious operation to embark vehicles for the amphibious operation. However, the logistics of storing Marines and their vehicles on an aircraft carrier could be complex.

Thus, Valor aircraft could transport an M777A2 towed artillery or 10,000 pounds of logistical supplies per lift out to $200 \mathrm{~nm}$ or more from an ATF. A Marine Air-Ground Task Force (MAGTF) composited for operations at this range would need to replace most of its King Stallions with Valor utility tiltrotors. Additionally, for operations at such distances, the transportation of LAV variants, HIMARS, JLTVs, and humvees would fall to ultra-heavy VTOL aircraft. Aircraft could also carry the Stryker family of vehicles, variants of the Oshkosh Defense Medium Tactical Vehicle Replacement (MTVR) with possible limitations on weight of payload, and, possibly, the Amphibious Combat Vehicle 1.1. However, for such amphibious operations, there will be a great demand for ultra-heavy VTOL aircraft, which could be very expensive to purchase and difficult to deploy to the area of operations in great number due to a need for refueling. At this range from an ATF, Osprey could still internally transport Growler ITVs, vehicles that may become the primary logistical vehicle in such long-range operations. Despite these drawbacks, such long-range amphibious operations may still be a useful tool against enemies with significant coastal defenses, but a limited number of main battle tanks or other heavy-armored vehicles in the amphibious objective area.

A downside to these solutions is that it will take approximately eight hours for an ATF to reach the shoreline from $200 \mathrm{~nm}$ away. The threat of mines and obstacles may greatly delay this already long period of time before surface resupply can occur. This means that Marines will have to fight without the support of Abrams main battle tanks, forcing them to rely on air resupply alone for hours and potentially much longer. Thus, a key aim for the landing force will be to mitigate the threat of coastal hypersonic missiles, antiship ballistic missiles, and antiship cruise missiles to the point that ships can land the rest of the MEB's personnel, vehicles, armor, and logistic support by coming closer to 
shore. However, the threat of inland antiship ballistic missiles, antiship cruise missiles, and hypersonic missiles will still exist.

The eventual replacement of the F/A-18E/F Super Hornet with the F/A$\mathrm{XX}$, if it has a larger combat radius, may allow for even more extreme longrange air assaults from the sea. These air assaults would take full advantage of the $428 \mathrm{~nm}$ combat radius of the Osprey to transport lightly armed forces. The cruising speeds of all these VTOL aircraft are not terribly dissimilar, except for an ultra-heavy VTOL aircraft, which will be faster than smaller aircraft, allowing for better options for forcible entry by allowing armed escorts of transport aircraft. Ultra-size aircraft also may have the range to slow down and be escorted by attack aircraft.

Therefore, assuming key acquisitions, the Marine Corps may be able to more than double the distance covered by its long-range amphibious operations that use heavy lift starting in 2028. This would require the acquisition of $\mathrm{Ma}$ rine Corps variants of the Valor utility tiltrotor, of the attack tiltrotor, and the future vertical lift competition for ultra-heavy VTOL aircraft. These capabilities also make it technically feasible for armored vehicles and logistical vehicles weighing 41,000 pounds or more to disembark from aircraft $200 \mathrm{~nm}$ or more from their ATF. This will allow for blue-water amphibious operations outside of a state's exclusive economic zone while giving Marines significant fire support from mortars, field artillery, VTOL aircraft, and fixed-wing aircraft; LAVs for reconnaissance and security; and vehicles for logistics beyond just ITVs.

If the Marine Corps procures another tiltrotor, then it also stands to benefit if it seeks to acquire new cargo transportation equipment, which takes full advantage of the speed of tiltrotors. If a Valor could utilize its full air speed, then the tempo of air resupply could increase.

Furthermore, ultra-heavy VTOL aircraft will provide a lightly armed force of Marines with more vehicles, artillery, heavier logistical vehicles, or heavier armored vehicles weighing 41,000 pounds or more. This equipment will be able to deploy hundreds of nautical miles from regional airbases with the aid of aerial refueling. However, Marines will be entirely reliant on ultra-heavy VTOL aircraft and Ospreys, both carrying internal cargo, for air resupply and medevac. Medevac also may take well more than an hour to transport a wounded Marine to a hospital aboard a ship. Thus, such operations may allow revolutionary capability but will come with some risks.

Finally, on their own, ultra-heavy VTOL aircraft operating from the continental United States, with the support of aerial refueling, could transport reconnaissance units or special operations forces with vehicles anywhere in the world. This could result in new capabilities for forces operating in areas with less sophisticated antiaircraft defenses. 


\section{Advantages of Long-Range Amphibious Operations}

There are quite a few advantages of long-range amphibious operations. By deploying landing forces $100 \mathrm{~nm}$ or more from shore, long-range amphibious operations mitigate the threat of antiship missiles, mines, tactical aircraft, and diesel submarines. They also allow an ATF the opportunity to remain undetected. Thus, long-range amphibious operations reduce the vulnerability of amphibious ships and their escorts. Long-range amphibious operations drastically increase the maneuver space available from the sea compared with amphibious operations that originate closer to shore, possibly allowing an ATF to stay in blue-water ocean outside of a nation's exclusive economic zone. Long-range amphibious operations allow an ATF the ability to threaten thousands of statute miles of coastline in a 24-hour period. This could force an adversary to deploy numerous forces across hundreds of statute miles of coastline to prevent a landing. Even then, the ATF may threaten enough coastline that an enemy finds it unfeasible to defend it all, allowing for unopposed landings, due to the shear amount of threatened coastline. Long-range amphibious operations also allow an ATF to deploy aircraft transporting lightly armed Marines hundreds of nautical miles from shore; this may give an ATF the option to maneuver close to allied military bases and expeditionary advance bases. Deploying from such as distance would also provide greater opportunity for an ATF to stay within reach of friendly land-based antiship weapons and aircraft.

An element of surprise is advantageous to long-range amphibious operations, which allows the amphibious force to dictate when and where to fight along vast amounts of coastline. Furthermore, these operations provide extraordinary mobility using aircraft to transport troops. This allows the landing force to quickly concentrate strength where the adversary is weakest along massive amounts of coastline, and it allows for the vertical envelopment of enemy forces.

The ATF also can easily threaten targets beside the immediate coast; longrange amphibious operations provide the ability to launch an amphibious operation against targets miles inland, even with an ATF positioned far from contested coastline. For instance, an amphibious operation with a range of 200 $\mathrm{nm}$ can deploy ships $100 \mathrm{~nm}$ from shore and still penetrate 115 statute miles inland. The ability to strike inland, past prepared defenses, allows landing forces to disembark on the flanks of enemy forces, to the rear of enemy forces, and against key targets such as command and control facilities, logistic sites, and lines of communication. ${ }^{46}$ Long-range amphibious operations composed primarily of infantry supported by artillery, aerial, and light-armored units may have effective combined arms for military operations on urbanized terrain, though main battle tanks brought by surface connectors would give such operations a more powerful combined arms capability. ${ }^{47}$ 
Long-range amphibious operations may disrupt an enemy by having the ability to choose where to engage an enemy across vast amounts of coastline and by having the aerial mobility to choose when and where to strike. It may be possible to stretch an enemy's communications, command and control, and intelligence to the point that they can no longer function. Between feints, other forms of deception, preassault raids, and the actual primary thrust of the amphibious assault, an enemy may simply be unable to coordinate or adapt to the challenge of defending vast amounts of coastline. Even if an enemy commander understood where the primary thrust of the amphibious assault was happening, the speed and range of Marine aircraft will allow troops and vehicles to isolate enemy forces, mass where the enemy is most vulnerable, and challenge the abilities of the enemy commanders to adapt.

Long-range amphibious operations enhance the effectiveness of amphibious raids. Such operations give raiders the ability to land a significant number of lightly armed forces to the flanks or rear of enemy positions and against key targets during a period of nautical twilight. The range of raiding could be up to $200 \mathrm{~nm}$ while armed with artillery and vehicles weighing 41,000 pounds or more.

By deploying aircraft from hundreds of nautical miles offshore, the ATF may gain the option to maneuver close to allied military bases and expeditionary advanced bases. This would provide greater opportunity for an ATF to stay within reach of friendly land-based antiship weapons and aircraft. Most notably, in the event of war with China, U.S. naval ships may be able to stay relatively close to military bases and expeditionary advanced bases built in the closest archipelagos to the Chinese coastline, particularly those that belong to Japan, the Philippines, and Taiwan. Having this option may deter Chinese aggression in the Asia-Pacific region, especially when combined with amphibious demonstrations.

Long-range amphibious operations allow for amphibious demonstrations that may deter adversaries of the United States with access to A2/AD technologies. Deception operations may also be enhanced by long-range amphibious operations. The shear amount of coastline threatened by an ATF operating 100 $\mathrm{nm}$ or more from the nearest coastline means that responding to deception operations may mass enemy forces in the wrong locations, creating weak points a commander can exploit.

Finally, long-range amphibious operations will allow U.S. naval ships to deploy assets in a humanitarian operation, while approaching stricken coastline from hundreds of nautical miles away. They will also give commanders the ability to conduct an amphibious withdrawal for many personnel, as well as a limited amount of cargo and vehicles, quickly and from many nautical miles out at sea, while mitigating the threat an adversary has against U.S. naval ships. 


\section{Disadvantages of Long-Range Amphibious Operations}

The above analysis shows that the type of amphibious operation with the least to gain from long-range capabilities may be an initial amphibious assault, because long-range amphibious operations assume that Abrams main battle tanks, AAVs, the logistics combat element, and the remainder of an MEB or MEU will need a suitable beach landing zone to disembark. Thus, one key goal for the initial landing force, if it wants to push inland with force, will be to seize a coastline and establish a logistic line of supply, with a debarkation of AAVs and Abrams battle tanks. However, if an objective could be taken by forces that are more lightly armed and armored, while supported by air resupply, then ship-to-objective maneuver could be used. However, against any near-peer competitor, armed with a very large number of main battle tanks, this could prove a rare occurrence.

Thus, in a long-range amphibious assault against a heavily defended objective, this military concept relies on the archaic practice of seizing a bridgehead to land more forces and organize for land combat to take an ultimate objective. There also will be a need to clear approach lanes of mines and other obstacles. Additionally, the initial landing force will make for a lucrative target for enemy forces beyond the amphibious objective area. Thus, if the ultimate objective is heavily defended, in order to succeed, the landing force and its fire support must quickly defeat enemy forces on the coastline, isolate the amphibious objective area from reserves, and destroy any weapons on the coast that could be used against their amphibious ships and landing craft. Otherwise, defending enemy forces could force a war of attrition in the amphibious objective area, counterattack from beyond the amphibious objective area, or they could target amphibious ships and their escorts.

Furthermore, medevac will present logistical problems for troops operating so far away from an ATF. The transit time back to a hospital aboard naval vessels may be more than an hour. Thus, the need for medevac aircraft that can swiftly get troops back to a hospital may limit the realistic range of long-range amphibious operations. Another disadvantage is that aircraft are weather dependent and, as such, operations in inclement weather will be impossible. This gives the enemy the assurance that operations cannot take place in bad weather.

Long-range amphibious operations present enormous challenges to such logistical aspects as intelligence, command and control, and communication. For example, the sheer number of intelligence products to sift through, when choosing where to strike along hundreds if not thousands of statue miles of coastline, will be daunting. An amphibious landing more than $100 \mathrm{~nm}$ from the nearest amphibious ships will present significant hurdles to overcome for surveillance, amphibious reconnaissance, and naval surface fire support. The distance inherent in these operations presents other issues; the farther an ATF 
is from the amphibious objective area, the longer it will take to disembark all troops there, which may rule out a rapid transport of all amphibious troops to the amphibious objective area in one period of nautical twilight.

Resupply will present obstacles as well. The only avenue of resupply will be aircraft until a suitable beach landing zone can be created. In addition, the tempo of air resupply may be slow due to the distances involved and may present hurdles that will limit the range of these types of amphibious operations. Furthermore, Osprey and ultra-size aircraft will require landing zones to gain access to their internal cargo. These long transit times for additional troops and supplies, combined with the fact that most Marines will be on foot, may make it difficult to achieve and hold the initiative beyond the first wave of Marines.

We must also consider logistical issues with enemy defensive capabilities in littoral combat zones. For example, A2/AD capabilities include air defenses, and they will need to be suppressed before the landing can occur. ${ }^{48}$ The ground maneuver element will be completely reliant on man-portable mortars and aircraft for fire support until artillery is flown in. Naval gunfire support cannot always be relied on, and massed enemy armor could overwhelm the landing force, due to its lack of main battle tanks, such as the danger armored units presented to airborne troops in World War II.

Yet, three major differences can be seen between modern-day actions and those in the Second World War. Man-portable antitank weapons have evolved considerably since World War II; lightly armed Marines possess weapons capable of defeating a main battle tank; and close air support has become significantly better. The Marines of the landing force may be able to fend off armored units through a combination of the antiarmor firepower they possess as well as artillery fire support. Marines may overwhelm armored units with the precision firepower provided by close air support, which could use ordnance such as the CBU-97 Sensor Fuzed Weapon. Of course, the opposite is also possible-that the landing force is defeated by massed armor.

While aircraft can help maneuver warfare and the massing of troops at weak points, the lack of main battle tanks and AAVs will slow the advance of troops when opportunities present themselves. Most of the landing force will likely be foot mobile Marines, who simply lack the speed to exploit every advantage that presents itself. This may result in a reduced ability to strike at an enemy's critical vulnerabilities and centers of gravity.

The former Commandant of the Marines, General James F. Amos, has referred to the Marines as "a middleweight force. We are light enough to get there quickly, but heavy enough to carry the day upon arrival." ${ }^{49}$ Conversely, the amphibious landing force presented in this future military concept is a more lightweight force. This drastic change of doctrine may in fact blunt the chief advantages of the U.S. Marine Corps. Thus, long-range amphibious operation 
will offer considerable advantages, but also considerable limitations, and such operations carry their own risks. Regardless of all these disadvantages, the quality and capabilities of Marines on foot and the quality and capabilities of the lightweight forces and aircraft supporting them determine how effective longrange amphibious operations can be.

\section{The Benefit of More Flight Deck Space in the U.S. Navy}

When analyzing long-range amphibious operations, a key limiting factor was the number of aircraft transported by an amphibious task force. In the aforementioned long-range amphibious operations, which rely on air assault, it should be noted that amphibious assault ships are far more valuable than San Antonio-class or LPD Flight II-class ships.

It takes around six San Antonio-class or LPD Flight II-class ships to equal the utility of one additional amphibious assault ship in terms of the number of aircraft that can be carried. Conversely, this means that adding an amphibious assault ship to an ATF results in adding the same number of aircraft found on six San Antonio-class or LPD Flight II-class ships. This reality for long-range amphibious operations exacerbates the need for more amphibious assault ships.

In addition, in 2015, a Rand report proposed the idea of a common mobile air platform that can interchangeably be used as a Navy carrier air wing or Marine Corps MEU support unit. ${ }^{50}$ This platform would be larger than the America-class ships and would provide the MEU and MEB with more air capability than these vessels. ${ }^{51}$ Such a ship would not have a well deck, which requires any cargo or equipment needing surface capability to be displaced onto ships with well decks. ${ }^{52}$

Another proposal set forth by Center for Strategic and Budgetary Analysis, MITRE Corporation, and the Navy is to alter the America-class amphibious assault ships into true aircraft carriers by making them larger and adding a catapult assisted take-off but barrier arrested recovery system for launching and arresting naval aircraft. ${ }^{53}$ Likely weighing between 40,000 and 60,000 tons, these light aircraft carriers could deploy Northrop Grumman E-2 Hawkeye aircraft, which would provide an airborne early warning capability to any amphibious or surface action force they join. ${ }^{54}$ They would also have the capability of operating Boeing EA-18G Growler aircraft, while also having substantially expanded flight deck and hangar space. ${ }^{55}$ If armed primarily with F-35 Lightning II aircraft, a CVL could contribute a powerful sea control and power projection role for an ESG. And, if armed primarily with VTOL aircraft instead of F-35s, CVLs could function as a larger version of America-class ships during an amphibious operation, expanding the air combat element of an ATF.

These two proposals are potentially beneficial, and the utility of each should be explored by the U.S. Navy and Marine Corps. The goal would be to gauge 
which proposal, or even an innovative idea to come, may best expand the number of aircraft, type of aircraft, and long-range amphibious operation capabilities available to amphibious forces.

\section{Recommendations}

The following recommendations are intended to decrease the deficiencies of long-range amphibious operations as outlined in this article. The Marine Corps should acquire an externally transportable sling load to take full advantage of the speed of tiltrotors; it should acquire both an attack and utility variant of the Bell V-280 Valor, if it performs as marketed, to provide the fire support and carrying capacity needed; and it should acquire a naval version of the future vertical lift competition's ultra-heavy VTOL aircraft to transport artillery and vehicles weighing 41,000 pounds or more in long-range amphibious operations. In addition, the Marine Corps should seek further innovative ideas for acquisition to overcome the surveillance, amphibious reconnaissance, communication, command and control, intelligence, and naval surface fire support hurdles for long-range amphibious operations. A key issue is the limited communication ranges for various small unmanned aerial vehicles.

The U.S. Navy should procure HVP rounds for its Mark 45 gun and make them the standard ammunition for naval gunfire support of amphibious operations. The U.S. Navy needs to acquire a long-range interim replacement for the Mark 45 gun for current destroyers and cruisers to provide longer-range naval gunfire support of amphibious operations, before the EMRG is fielded on future surface combatant destroyers. The U.S. Navy should either acquire additional amphibious assault ships faster, acquire ships to act as either a Navy carrier air wing or a Marine Corps MEU support unit, and/or redesign the America-class ships to operate as true light aircraft carriers. Finally, the Navy should seek a greater combat radius than the F/A-18E/F with its future F/A-XX aircraft to increase the range of extreme long-range amphibious operations to $428 \mathrm{~nm}$ with lightly armed Marine forces.

\section{Conclusions}

The goal of this analysis is to assess the technological capabilities, limitations, and vulnerabilities of long-range amphibious operations through the year 2028. For long-range amphibious operations using the CH-53K King Stallion, it is feasible to use an air combat element to transport, provide fire support for, and provide air resupply for Marines, batteries of M777A2 towed artillery, HIMARS, LAVs, JLTVs, and humvees deployed by air from an ATF up to $110 \mathrm{~nm}$ from shore. Starting in 2028, this capability could include vehicles or artillery weighing 41,000 pounds or more and extend out to $200 \mathrm{~nm}$ or more with the right acquisitions. 
However, the transportation of Abrams main battle tanks and, possibly, AAVs was found to be unfeasible by VTOL aircraft in the near future. To provide these vehicles and heavy logistic support to the landing force, it would require a fleet of amphibious ships close to approximately $100 \mathrm{~nm}$ to shore to launch surface connectors from long range. However, there is no way to provide large numbers of armored vehicles without sending a number of amphibious ships close to shore, potentially obviating many of the advantages of long-range amphibious operations.

In addition, adding naval gunfire support to such long-range amphibious operations requires that a fleet of large surface combatants come close to shore while using HVP ammunition, and possibly Excalibur N5 ammunition, exclusively, until there is widespread use of a replacement to the Mark 45 gun. The current replacement to this method of support will likely be EMRGs on future surface combatant destroyers, which will not be fielded until the early 2030s. Therefore, it was determined that a long-range interim naval gun is needed for destroyers and cruisers.

Furthermore, a key limiting factor for long-range amphibious operations is the size of the air combat element. This problem is best addressed by increasing the air combat element through the expedited purchase of more amphibious assault ships, as well as acquiring ships to act as either a Navy carrier air wing or a MEU support unit-or to make the America-class ships into true light aircraft carriers. The ultimate purpose of this potential military concept is to incite further discussion on future strengths and limitations of long-range amphibious operations. The untested concepts here will require testing by strategists and commanders long before use in simulations and wargames.

\section{Notes}

1. Bryan Clark et al., Restoring American Seapower: A New Fleet Architecture for the United States Navy (Washington, DC: Center for Strategic and Budgetary Assessments, 2017).

2. Ian Speller and Christopher Tuck, Amphibious Warfare: Strategy and Tactics from Gallipoli to Iraq (London: Amber Books, 2014), 48-50.

3. Speller and Tuck, Amphibious Warfare, 159.

4. Bradley Martin, Amphibious Operations in Contested Environments: Insights from Analytic Work (Santa Monica, CA: Rand, 2017), https://doi.org/10.7249/CT476. This report was based on the transcript of testimony presented before the House Armed Services Committee, Subcommittee on Seapower and Projection Forces on 18 May 2017.

5. "V-22 Osprey," Boeing.

6. "V-22 Osprey," Boeing.

7. "V-22 Osprey," Naval Technology.

8. "M-1161 Internally Transportable Vehicle (ITV), Light Strike Vehicle (LSV)," Growler Manufacturing \& Engineering BHG, 2014.

9. "V-22 Osprey," Naval Technology.

10. "Tilt Rotor: V-22 Osprey," Marine Aviation.

11. "F/A-18 Hornet," FAS Military Analysis Network, 2 November 2016.

12. "F/A-18 Super Hornet," Boeing. 
13. "F-35 Lightning II Program Status and Fast Facts," Lockheed Martin, 2 July 2018.

14. "Sikorsky CH-53K Helicopter," Lockheed Martin.

15. "High-Mobility Rocket System (HIMARS)," Army Technology; "Sikorsky CH-53K Helicopter," Lockheed Martin; and "CH-53K King Stallion," Naval Air Systems Command, U.S. Navy, April 2016.

16. "Bell AH-1Z: World's Most Advanced Attack Helicopter," Bell.

17. A statute mile is the definitive measure used in Britain and America and refers to miles on roads signs or maps. The U.S. statute mile measures 1609.3472 meters, a difference of 3.2 millimeters ( $1 / 8$ inch) per mile due to using the equation of a survey foot equaling 1,200/3,937 meters rather than 30.48 centimeters. Nautical miles are measured different than miles due to the nature of sea travel. They are measured using the arc of the Earth, and are 1 percent of 1 degree of the Earth's curve. Because that curve is not completely even and spherical, in some areas, a nautical mile is larger than in others. In 1954, America agreed that the international nautical mile of 1,852 meters would be adopted.

18. James F. Dunnigan, How to Make War: A Comprehensive Guide to Modern Warfare in the 21st Century, 4th ed. (New York: HarperCollins, 2003), 179.

19. "V-22 Osprey," Boeing.

20. "Lessons from Rhino LZ: How the Afghanistan Invasion Changed Combat Airlift," Armed Forces Journal, 1 November 2011.

21. Military Operations on Urbanized Terrain (MOUT), MCWP 3-35.3 (Washington, DC: Headquarters Marine Corps, 1998), 1-10.

22. Employment of the Light Armored Reconnaissance Battalion, MCWP 3-14 (Washington, DC: Headquarters Marine Corps, 2009), 3-1.

23. Dunnigan, How to Make War, 105-6.

24. Speller and Tuck, Amphibious Warfare, 77-80.

25. "Landing Craft, Mechanized and Utility_LCM/LCU," U.S. Navy, 12 January 2018; and "Amphibious Combat Vehicle 1.1," BAE Systems.

26. "Landing Craft, Air Cushion: Redefining State-of-the-Art Amphibious Capabilities," Textron Systems, 2015.

27. "Ship-to-Shore Connector," Textron Systems, 2016.

28. "Landing Craft, Air Cushion (LCAC)," FAS Military Analysis Network, 14 February 2000.

29. “MK 45-5-Inch-Gun 54/62 Caliber Guns,” U.S. Navy, 25 January 2017.

30. Sam LaGrone, "Navy Requires $\$ 450$ Million More to Complete Zumwalt-Class Due to Shipyard Performance," USNI News, 6 April 2016.

31. Christopher P. Cavas, "New Warship's Big Guns Have No Bullets," Defense News, 6 November 2016.

32. Cavas, "New Warship's Big Guns Have No Bullets."

33. Cavas, "New Warship's Big Guns Have No Bullets."

34. "Advanced Gun System (AGS)" BAE Systems.

35. Kyle Mizokami, "The Navy's Railgun Is about to Get Faster and More Powerful," Popular Mechanics, 24 July 2017.

36. Mizokami, "The Navy's Railgun Is about to Get Faster and More Powerful."

37. Mizokami, "The Navy's Railgun Is about to Get Faster and More Powerful."

38. "Hypervelocity Projectile," BAE Systems.

39. "Bell V-280 Valor: Transformational Reach, Revolutionary Capability," Bell.

40. Jeremiah Gertler, V-22 Osprey Tilt-Rotor Aircraft: Background and Issues for Congress (Washington, DC: Congressional Research Service, 2011).

41. "M777 Lightweight Towed 155mm Howitzer," BAE Systems.

42. Multiservice Helicopter Sling Load: Basic Operations and Equipment, FM 10-450-3 (Washington, DC: Headquarters Department of the Army, 1997).

43. "155mm M107 HE: High Explosive," General Dynamics.

44. Speller and Tuck, Amphibious Warfare, 117.

45. Stephen Trimble, "US Army Reveals Details of Joint Multi-Role Fleet Vision," FlightGlobal, 16 August 2011. 
46. Jerome F. Bierly and Thomas E. Seal, "Over-The-Horizon Amphibious Operations," Marine Corps Gazette 75, no. 7 (July 1991).

47. Military Operations on Urbanized Terrain, 1-16.

48. Martin, Amphibious Operations in Contested Environments.

49. Bill Johnson-Miles and Barb Hamby, "MCSC equips the Nation's 'Middleweight' Force to Win," Marine Corps Systems Command, 9 June 2011.

50. Martin, Amphibious Operations in Contested Environments.

51. Martin, Amphibious Operations in Contested Environments.

52. Martin, Amphibious Operations in Contested Environments.

53. Peter Haynes, "The Time is Right for Light Carriers," Center for Strategic and Budgetary Assessments, 25 April 2017; and Navy Future Fleet Platform Architecture Study (McLean, VA: MITRE, 2016).

54. Haynes, "The Time is Right for Light Carriers"; and Navy Future Fleet Platform Architecture Study.

55. Haynes, "The Time is Right for Light Carriers"; and Navy Future Fleet Platform Architecture Study. 


\title{
Cities and the Sea The Urban Role in Maritime Security
}

\author{
Joshua Tallis and Ian Klaus
}

\begin{abstract}
In this article, the authors explore the role cities play in maritime security. Urban centers have a complicated relationship with the maritime space. On the one hand, cities are major contributors to insecurity along their maritime borders, exacerbating issues from human trafficking to illegal fishing. On the other hand, cities are increasingly at the center of international consensusbuilding and problem-solving forums that are producing results even as nations fail to come to agreement on similar challenges. As the world returns to an emphasis on great power competition, cities offer a complementary set of actors and venues in the global arena by which to pursue greater international stability and security.
\end{abstract}

Keywords: maritime security, cities, urbanization, megacity, piracy

$\mathbf{T}$ he city and the sea are intertwined instruments and icons of globalization. It is no coincidence that the principles that have long defined networks of seaborne commerce-multiculturalism, economic dynamism, and ideological diversity - are the same notions we associate with urbanites today. And just as cosmopolitan, littoral cities have emerged, in part, from global trade and exchange, so too do they now face the transnational threats unique to this particular era of globalization. As a result of the dynamic relationship be-

Ian Klaus is a nonresident fellow at the Chicago Council on Global Affairs. He was previously senior advisor for global cities at the U.S. Department of State and deputy U.S. negotiator for Habitat III. Joshua Tallis is an analyst at the Center for Naval Analyses, a nonprofit research and analysis organization. He is the author of the forthcoming book The War for Muddy Waters: Pirates, Terrorists, Traffickers, and Maritime Insecurity. The views in this article are the authors' own and do not represent the positions of current or previous employers.

MCU Journal vol. 9, no. 2 
tween cities and the sea, municipal and national governments should consider the role of cities and urban leaders in securing maritime spaces.

The call for this assessment may seem at odds with the current emphasis on great power competition. Indeed, the Pentagon's latest National Defense Strategy clearly outlines that the DOD is rebalancing to place deterring (and, if need be, winning) near-peer interstate conflict ahead of the less conventional threats the DOD has addressed since 11 September 2001 (9/11). Much of this rebalancing is warranted-great powers are the only states with the capacity to existentially threaten the United States, while spoilers or rogue regimes remain threats to U.S. interests (in a more limited fashion). ${ }^{1}$ Yet, even in this emerging world dynamic, a parallel international force is rising economically, socially, and politically, if not militarily-the city.

As we will explore in this article, cities are rapidly becoming units of action on the global stage. They advocate for social, political, and economic agendas at international forums. They sometimes pursue agendas out of step with their parent government. And, increasingly, cities are home to complicated security dynamics. The tools and tactics the United States cultivates to deter (or defeat) Russia or China do not necessarily reflect those needed to operate in a city. Relatedly, as we will explore in this article, the very actors that the United States would need to engage with to secure littoral cities are wholly different from those involved in great power conflict. Even as the United States-and indeed, the global community - prepares for a reorientation toward a more competitive state environment, ignoring the role of cities as both partners in security and locations of potential conflict is ill-advised. In an era of great power politics, after all, they provide both the opportunity for influence and, even as tensions rise, sites for collective action.

\section{Cities as Hubs for Illicit Trade}

As with so many urban issues, the challenges of the littoral city are inextricably linked to opportunities. Consider the importance of seaborne trade to global cities. More than 90 percent of legal goods move by sea, including nearly onehalf of all petroleum. ${ }^{2}$ At the same time, however, global trade generates its own urban instability. Counterfeit products from fake prescription medications to cigarettes are in high demand in global cities and are often moved by maritime routes. Forced laborers and sex workers are trafficked in cargo containers or fishing trawlers to meet growing demands in coastal cities. In short, if cities are the engines of global commerce, they will likewise be increasingly confronted by the role their maritime borders play in facilitating demand for products, licit and illicit alike.

Illegal, unreported, unregulated (IUU) fishing offers a stark example. Rising populations and wealth concentrated in developing cities, particularly in 
Asia and Africa, have driven up demand for fish. This demand is often met by illegal and unsustainable practices that degrade fish stocks. Urbanization plays an important role in this degradation both through supply-chain facilitation and market demand. Growing cities often come with improved logistics and infrastructure, providing a suitable cold chain to support the trade in perishable products like fish and animal protein. ${ }^{3}$ Meanwhile, urbanization also manifests changes in dietary patterns compared to rural regions of the same country. Cheaper, more diverse food options arising in part from a more sophisticated urban logistics network results in diets that are higher in animal protein consumption, including fish, than traditional rural diets. ${ }^{4}$ Whereas, in the 1960s, average per capita fish consumption was slightly less than 10 kilograms, that figure has today more than doubled. ${ }^{5}$ Pollution and urban runoff further damage local fish stocks and diminish total available marine resources. For those reasons, IUU fishing has caught increased attention from senior national security officials. Former Supreme Allied Commander Admiral James G. Stavridis, for example, has noted the potential for global fishing wars, especially in Asia, an issue that may assume new risk and relevance in an era of great power rivalry. Congress, as part of the National Defense Authorization Act for Fiscal Year 2018, also asked the U.S. Navy to address IUU fishing as part of its portfolio of security challenges. ${ }^{6}$ Why all this attention on fish? Most directly, IUU fishing jeopardizes food security for the nearly 1 billion people who rely on fish as their primary source of protein. ${ }^{7}$ Moreover, the global export value of the fishing industry approaches $\$ 150$ billion annually, meaning more than 56 million people rely on sustainable fishing as a means of employment. ${ }^{8}$

Lagos, Nigeria, offers an example of how these trends collide in an urban setting. The city is vulnerable to a region-wide food-security dilemma. In a part of the world where more than half of protein consumption comes from fish, and the industry is worth upward of U.S. \$20 billion and is one of the largest non-oil related sources of rent (i.e., sources of income), one Chatham House report refers to IUU fishing in the Gulf of Guinea as "probably far more important in West Africa than piracy." Overfishing presents risks to the food security of those most vulnerable in a growing city and to those who depend on the industry for income. And while IUU fishing occurs across the region and cannot be tied to any one city, Lagos remains a port of entry for illegally fished products and therefore a substantial employment and agricultural benefactor of the trade. As the hub of West Africa's economy, though, Lagos is also particularly damaged by the economic losses from IUU fishing. One source estimates the total loss in dollars to Nigeria's economy during a five-year period as between $\$ 300$ and $\$ 400$ billion. ${ }^{10}$ Oil spills in Nigeria only exacerbate these effects. ${ }^{11}$

IUU fishing also has long been identified as a precursor to other maritime crimes, such as piracy, as was argued with the rise of Somali piracy in the 
1990s. ${ }^{12}$ In that instance, one interpretation of the rise of Somali piracy held that toxic dumping and overfishing by foreign interests drove artisanal fishermen from traditional waters. As a source of income and food dissolved, the fishermen increasingly turned to policing their waters themselves, which over time warped into the rampant piracy witnessed off the Horn of Africa. As with any criminal endeavor, IUU fishing attracts organized crime-groups that, as a rule, diversify their criminal activities to build both growth and resilience. ${ }^{13}$ It is no surprise, therefore, that there remains a longstanding, self-perpetuating relationship between IUU fishing and human trafficking. ${ }^{14}$ As documented by the International Labour Organization and the Associated Press, a growing demand for seafood is often met by the hands of forced laborers and vulnerable migrants. ${ }^{15}$

Human trafficking also offers another insightful example of the relationship between urbanization and maritime security. Cities are hubs for human trafficking and smuggling. Demand for labor in industries like construction, facilitated by the lure of better financial prospects, lubricates the flow of unskilled rural laborers to cities around the world. Many, upon arrival, find themselves deep in debt and forced to repay exorbitant travel fees and costs of room and board. Meanwhile, the rise in disposable incomes that often comes with urbanization can drive up demand for sex trafficking. Women and girls face particularly high risk factors and comprise a majority of trafficking victims, who are then redirected in existing irregular migration flows-they are often enticed to leave home in search of better work - to sustain the massive demand for forced sexual exploitation. ${ }^{16}$ The rise of an urban middle class also precipitates a desire for domestic labor. Houseworkers often face the same obstacles as forced laborers in other sectors - unreasonable travel fees, charges for room and board, and confiscated passports.

Bangkok is an archetype of the convergence of these trafficking trends. Thailand has attracted an estimated 4 million non-native migrants, most of them arriving irregularly. Those 4 million migrants are at high risk of trafficking from the very beginning of their travels. While there are many overland routes, travel by sea remains a well-worn path. Some migrants from Cambodia, for example, first travel by boat to Malaysia before continuing on to Thailand overland. ${ }^{17}$ Those arriving from Laos and Myanmar are perhaps most likely to take the arduous journey by boat, either navigating local rivers or coming indirectly through the Andaman Sea.

Locations of first entry vary, but Bangkok is often the ultimate destination because large cities offer higher potential salaries. According to the United Nations (UN), 40 percent of all migrants live in or near Bangkok. At the most extreme count, nearly one-quarter of those migrants (1 million people) may be victims of trafficking. ${ }^{18}$ Bangkok's thriving tourist industry is a particular 
driver both of irregular migration and subsequent human trafficking. Cambodian, Laotian, and Burmese children are frequently trafficked to Bangkok and serve as beggars in tourist neighborhoods. ${ }^{19}$ Additionally, Bangkok has become infamous as an international capital for sexual exploitation. The sea plays a vital role in facilitating the flow of people from rural communities to growing cities. Once there, many migrants reap the benefits of Bangkok's dynamic economy, while others endure hardship and a violation of basic human rights.

\section{The Governance and Misgovernance of Cities}

Rapid rates of urbanization amplify transnational challenges while giving rise to new networks and centers of power, thus providing new opportunities for political, economic, and security relationships and influence. The highest rates of urban growth are frequently found in the global south, in cities with limited capacity to keep pace with changing conditions. Dhaka, Bangladesh, has grown by as much as 5,400 percent during the last 65 years. ${ }^{20}$ If New York City had grown at the same pace, its population would now be nearing 700 million. ${ }^{21}$ When the sheer scale of residents outweighs a municipality's capacity to govern, some cities may lose control of some or all of the inhabitants they purport to administer. Richard J. Norton referred to these as feral cities, or places where the government "has lost the ability to maintain the rule of law within the city's boundaries yet remains a functioning actor in the greater international system."22 Many such cities are a mishmash of formal and informal governance, with some pockets governed by informal organizations and actors rather than government entities. Some such informal organizations are benign, even beneficial, for inhabitants. Others are more nefarious in intent and consequence. Poorly supported urban communities can fall victim to the predations of pirates, drug cartels, insurgents, and gangs_-all of whom may leverage their access to the sea to move people and products with impunity.

Kingston, Jamaica, as profiled in David Kilcullen's Out of the Mountains, provides an extreme example of a feral pocket. In the case of the Tivoli Gardens neighborhood, the community fell subject to a criminal group enriched by narcotics trafficking (often by maritime means), the Shower Posse, led by Christopher Coke. ${ }^{23}$ Coke's organization had insinuated itself as the de facto political arbiter and police force in his community, buying acquiescence though a combination of patronage (fueled by illicit enterprises), violence, and rule setting. ${ }^{24}$ When Jamaica faced pressure to arrest Coke in 2010, he had become so entrenched that the operation looked like a military assault. Some took up arms to defend him, while many cowered under an assault that briefly sent Jamaica into a state of emergency. ${ }^{25}$ Of course, Kingston is not Mogadishu, Somalia. And yet, "gang enclaves operated as autonomous mini-states" there, fed by the proceeds of maritime insecurity. ${ }^{26}$ Kingston typifies the feral pocket and 
serves as a cautionary extreme for the urban consequences of instability at sea.

Finally, while transnational criminal groups often work intentionally under the radar, other organizations use any vacuum in local territorial control to wreak havoc. Though overt utilization of the seas by terrorists remains rare, terrorists and insurgents have (in echoes of the 2008 Mumbai assault) used the sea as a space for maneuver in attacks in Tunisia (2015), Egypt (2016), and Côte d'Ivoire (2016). ${ }^{27}$ Pointedly, attacks are often on seaside hotels, with deleterious effects for the tourism industries upon which many municipal and national economies rely. Similar concerns about the consequences of violence on tourism have resulted in major diplomatic efforts in other regions, such as the Caribbean, where conflicts between traffickers and police in countries like Jamaica or Trinidad and Tobago have triggered travel alerts by Western nations. ${ }^{28}$ Such travel advisories, issued by countries upon which coastal cities rely for tourism, have precipitated national-level responses, with special delegations dispatched to resolve the crisis. $^{29}$

The urban relationship with the maritime sphere is dynamic; cities precipitate demands that are often met at the expense of, or via, the seas. Urban financial opportunities and demand for cheap labor precipitate the smuggling and trafficking of people by sea, while demand for counterfeit products, narcotics, and weapons are satiated in part by illicit seaborne deliveries. Cities are consumers of goods extracted from the sea, while such consumption places both food stocks and local industries at risk. Pollution further exacerbates the degradation of coastal communities and food security. Finally, cities remain targets for extremists, who may leverage the sea as a space for maneuver, threatening lives and the sustainability of regional tourist economies.

As cities in the global south continue to grow and thrive, how cities manage maritime insecurity, and the partners they look to help them in doing so, will have ramifications far beyond city lines. The return to great power politics does not negate these challenges. To the contrary, it heightens the importance, as we will later outline, of collaboration between cities on shared challenges, offering as they do the opportunity for policy exchange across borders and transnational collaboration despite new or renewed international tension. Cities offer a final challenge, this one predominantly bureaucratic in nature: the U.S. national security processes and apparatuses are not designed with cities in mind. Ensuring that the obstacles and opportunities unique to cities are identified and pursued will require that existing institutions make room for voices at the urban level of analysis. The National Security Council (NSC), DOD, Department of State, and relevant intelligence agencies could consider integrating urban expertise into their policy processes, combatant commands, and regional or thematic offices to serve as internal advocates for tracking urban trends with security relevance. ${ }^{30}$ That same expertise should be applied to the policies, plans, and 
strategies developed by these offices to ensure that issues of national significance are infused with urban knowledge where relevant.

The 9/11 terrorist attacks produced a paradigm shift in the way the nation negotiated the divide between homeland security and national defense. Domestic intelligence agencies such as the Federal Bureau of Investigation (FBI) and foreign collection enterprises such as the Central Intelligence Agency (CIA) and the National Security Agency (NSA) were directed to find better ways to cooperate. The NSA was given a chair on the Homeland Security Council. An entire cabinet bureaucracy, the Department of Homeland Security, was stood up to coordinate the homeland effort. The rise of cities may not require such a dramatic set of bureaucratic changes, but the fundamental lesson about deconstructing barriers is instructive. Just as homeland security needed more empowered and elevated voices, so too should the urban element garner more prominence across the U.S. interagency to cooperate with the unique challenges that large cities face in an increasingly connected and globalized world.

\section{What Can Be Done?}

As a result of the dynamic relationship between cities and the sea, all levels of government and intergovernmental bodies should consider the role of urban leaders in securing the maritime space. Solutions and policies must be developed and deployed at the municipal, national, regional, and international levels. ${ }^{31}$ Ideally, those solutions and policies would also be aligned vertically, with international norms and national polices enabling local solutions. In reality, approaches are often more scattershot and stove piped, with cities, national governments, and international organizations developing different approaches with varied timelines. Nonetheless, quite a few general approaches have been developed for meeting global challenges at the municipal level that can be tailored to urban maritime security initiatives.

First, international organizations will need to improve their program delivery and support for member states around this nexus. The Organization for Security Co-operation in Europe (OSCE) is expanding its work around city security - this must include a littoral focus. As the UN builds out urban counterterrorism programs in cities like Marawi, Philippines, in 2018, they must also include a focus on the sea. UN Habitat, which convenes the World Urban Forum, the world's largest biannual gathering on city issues, must ensure that issues around maritime security feature on the agenda for designers, sustainability directors, and development experts who bring urban-focused skill sets to what are now global challenges.

Second, national governments are going to have to continue to adapt to operating in challenging urban environments, even as other theaters and threats regain prominence. The approach to urban security developed during the Iraq 
War was largely built around landlocked cities. ${ }^{32}$ At the 2017 Future of War Conference, U.S. Army Chief of Staff General Mark A. Milley noted that in the future we must expect war to be urban (and, we would add, coastal). General Milley noted, "We're going to have to optimize the army for urban warfare." 33 In the decades to come, however, the urban terrain will also increasingly be maritime. In 2017, the chief of naval operations noted in his white paper "The Future Navy" the importance of urbanization in the future security environment but did not explore the implications of this phenomena. ${ }^{34}$ Likewise, a 2014 Army report from the chief of staff of the Army's Strategic Studies Group argues that "it is highly likely that the megacities will be the strategic key terrain in any future crisis that requires U.S. military intervention." 35 Already, about one-half of the people in the world live within walking distance (30 miles) of a coast, and approximately 75 percent of big cities are coastal. ${ }^{36}$ And the numbers will not stop growing anytime soon; right now, 1.5 million people migrate to a city every week. ${ }^{37}$

Additionally, of course, the force most likely to operate in a coastal megacity is the Marine Corps. Brigadier General Julian D. Alford, then-commander of the Marine Corps Warfighting Laboratory, noted in 2015 that despite the growing likelihood of urban (specifically, megacity) operations in the future, his training did not reflect a deep preparation for such combat: "I've trained in every environment, jungle, the desert, the mountains, cold weather, but I've never really trained well in an urban environment . . . the first time I ever dropped a bomb, shot a rocket, threw a grenade, killed a person was for real in an urban environment. . . . That should never happen again." ${ }^{38}$ Marine Corps Commandant General Robert B. Neller noted, however, that simulating such an environment is exceedingly complicated: "We can't afford to go out and build a 20-story skyscraper at Twentynine Palms [, California,] or stack shipping containers that high, we are just not going to do that." ${ }^{39}$ And even if we could, operating in a city, especially a megacity, is not only a matter of the built environment, but of understanding the complex, minute dynamics that move a city. Understanding a city's disposition-its propensity to act, its character, as Keller Easterling has written - is a matter well beyond replicating its buildings. This is a challenge not only of material but of knowledge. ${ }^{40}$ The Army's strategic studies report concludes:

A gap exists in the Army's doctrinal understanding of large cities. Moreover, megacities are not treated as units of analysis for study and intelligence collection or featured in planning scenarios. The Army, and the DoD community more broadly, neither understands nor prepares for these environments. ${ }^{41}$

Preparing to operate in cities (or, ideally, avoiding doing so) necessitates build- 
ing a complete picture of their relationship to threats in all domains, including the sea. Only then can we begin improving force structure planning or refining intelligence analysis efforts.

Critically, cities can and must take action themselves. Indeed, cities are increasingly taking action on transnational challenges, with many efforts coordinated and international. Work in the climate change space is the most advanced and instructive. Backed by significant philanthropies and organized around networks (e.g., C40 Cities, the Global Covenant of Mayors, Local Governments for Sustainability, United Cities and Local Governments, and the Urban Sustainability Directors Network), cities are collectively committing to action to mitigate carbon emissions, at times superseding nations' inaction or ineffective coordination, at others contributing to ongoing efforts by states. ${ }^{42}$ Networks amplify the collective voice of mayors and enable and support policy learning, exchange, and innovation. And the model is already adapting to an expanded set of challenges. C40 Cities, for example, has subnetworks focused on a range of issues, including food security and energy. Cities have also acted together to apply pressure and share policy perspective at international gatherings. Mayors were highly visible at the climate Conference of the Parties (COP) $21 \mathrm{UN}$ Framework Convention on Climate Change (UNFCCC) negotiations in Paris in 2015, as well as at subsequent UNFCCC meetings in Marrakesh, Morocco, in 2016 and Bonn, Germany, in 2017.

There is similar such work in early stages in the security space. Some of this is being done by cities in isolation, such as the longstanding deployment of intelligence officials by New York City to nearly a dozen countries. Or, as in the climate space, by the development of networks like the Strong Cities Network (SCN). The SCN has developed an updated version of "twinning" that links cities with similar violent extremism dynamics that enables cities to access policy solutions from around the world. These initiatives are a good start, but cities - backed by national governments - should explore how they can collaborate and share learning on maritime security issues more directly using the models they already have on hand.

Finally, the return of great power politics does not mean the urban arena is any less relevant-indeed, it should encourage us to explore in greater depth the interaction between urban and national issues. The Sister Cities program, for example, though focused on cultural exchange and people-to-people diplomacy, was in part a product of great power tensions. While recognizing the primacy of national governments on many security issues, cities, and in particular their practitioner experts, can and have maintained communication on shared challenges during periods of tension. Even as the 2017 G20 in Germany and 2018 G7 in Canada failed to produce consensus, for example, the world's largest and 
most influential cities gathered together in advance of the 2018 Argentina G20 to forge consensus around many global challenges. ${ }^{43}$ This urban cooperation can even serve as a means of relieving tensions that accumulate on the national level as the world returns to heightened rhetoric on great power competition.

\section{Conclusion}

Maritime security has a distinctly urban manifestation. Cities benefit from the sea even as the conditions of urbanization facilitate maritime instability. From demand for protein satiated in part by illegal fishing to a demand for labor met in part by human trafficking, cities face important imperatives to be partners in securing maritime spaces. A path for how cities can go about doing so is already charted in the climate sphere, where cities have demonstrated the ability and willingness to engage on issues of global consequence at a grassroots level. More is required on this effort in the security arena, where less traditional challenges of human security in particular (e.g., trafficking in persons and forced labor) warrant more serious attention. Meanwhile, cities require support from national leaders. Politicians and policy makers have a responsibility to address, not just leverage, the urban relationship with maritime security. As great power politics return, nations will have to decide whether to engage cities as competitive sites for influence or as locales (and partners) for collective action on shared challenges. Doing so will help safeguard cities against the worst manifestations of disorder, spaces governed by malicious nonstate actors, while encouraging analyst policy makers to think more critically about how to both fight and avoid fighting in such tumultuous terrain.

\section{Notes}

1. Summary of the 2018 National Defense Strategy of the United states of America: Sharpening the American Military's Competitive Edge (Washington, DC: Department of Defense, 2018).

2. "IMO Profile," International Maritime Organization, accessed 4 January 2018; and Rania El Gamal, "Factbox: Middle East Oil, Gas Shipping Risks, Alternative Routes," Reuters, 26 March 2015.

3. "Nutrition: Global and Regional Food Consumption Patterns and Trends," World Health Organization, accessed 4 January 2018.

4. John Kearny, "Food Consumption Trends and Drivers," Philosophical Transactions of the Royal Society B: Biological Sciences 365, no. 1554 (September 2010), http://dx.doi .org/10.1098/rstb.2010.0149.

5. Capt Jay Caputo, USCG, "A Global Fish War is Coming," Proceedings Magazine (U.S. Naval Institute) 143, no. 8 (August 2017).

6. James G. Stavridis and Johan Bergenas, "The Fishing Wars Are Coming," Washington Post, 13 September 2017.

7. Stavridis and Bergenas, "The Fishing Wars Are Coming."

8. The State of World Fisheries and Aquaculture 2016: Contributing to Food Security and Nutrition for All (Rome: Food and Agriculture Organization of the United Nations, 2016).

9. Lisa Otto, "Westward Ho!: The Evolution of Maritime Piracy in Nigeria," Portuguese 
Journal of Social Science 13, no. 3 (September 2014): 318, https://doi.org/10.1386/pjss .13.3.313_1; and Maritime Security in the Gulf of Guinea (London: Chatham House, 2013), 16.

10. Otto, "Westward Ho!," 319.

11. Otto, "Westward Ho!," 318.

12. Mariama Sow, "Figures of the Week: Piracy and Illegal Fishing in Somalia," Africa in Focus (blog), Brookings, 12 April 2017.

13. Don Liddick, "Illegal Fishing and Organized Crime: A Threat to Maritime Security?," Piracy Studies, 9 December 2014.

14. Caught at Sea: Forced Labour and Trafficking in Fisheries (Geneva: International Labour Organization, 2013).

15. Caught at Sea; and "Seafood from Slaves: An AP Investigation Helps Free Slaves in the 21st Century," Associated Press, accessed 4 January 2018.

16. "Report: Majority of Trafficking Victims Are Women and Girls; One-Third Children," Sustainable Development Goals (blog), United Nations, 22 December 2016.

17. Trafficking in Persons from Cambodia, Lao PDR and Myanmar to Thailand (Bangkok: United Nations Office on Drugs and Crime, 2017).

18. Trafficking in Persons from Cambodia, Lao PDR and Myanmar to Thailand.

19. Trafficking in Persons from Cambodia, Lao PDR and Myanmar to Thailand.

20. P. H. Liotta and James F. Miskel, The Real Population Bomb: Megacities, Global Security $\&$ the Map of the Future (Dulles, VA: Potomac Books, 2012), 5.

21. Liotta and Miskel, The Real Population Bomb, 5.

22. Richard J. Norton, "Feral Cities," Naval War College Review 56, no. 4 (Autumn 2003).

23. David Kilcullen, Out of the Mountains: The Coming Age of the Urban Guerrilla (London: C. Hurst, 2013), 93.

24. Kilcullen, Out of the Mountains, 95.

25. Kilcullen, Out of the Mountains, 89-90.

26. Kilcullen, Out of the Mountains, 99.

27. Peter Lehr, "(No) Princes of the Sea: Reflections on Maritime Terrorism," in Routledge Handbook of Naval Strategy and Security, ed. Joachim Krause and Sebastian Bruns (Abingdon, UK: Routledge, 2016). In “(No) Princes of the Sea," Lehr explores the fact that acts of terror at sea remain exceedingly rare, perhaps only 1 or 2 percent of all terrorist incidents according to some databases. Norman L. Cigar, The Jihadist Maritime Strategy: Waging a Guerrilla War at Sea, MES Monographs no. 8 (Quantico, VA: MCU Press, 2017).

28. Ramesh Deosaran, "A Portrait of Crime in the Caribbean: Realities and Challenges," in Caribbean Security in the Age of Terror: Challenge and Change, ed. Ivelaw Lloyd Griffith (Kingston, Jamaica: Ian Randle Publishers, 2004), 114.

29. Deosaran, "A Portrait of Crime in the Caribbean," 114.

30. "Serve and Predict: Violent Crime Is Down in Chicago," Economist, 5 May 2018. Chicago has forged a partnership, for example, between the police department and the University of Chicago's crime lab to leverage data analytics as a crime prediction and prevention tool.

31. See the New Urban Agenda (New York: United Nations, 2017); Neil Brenner, New State Places: Urban Governance and the Rescaling of Statehood (New York: Oxford University Press, 2004); and Keller Easterling, Extrastatecraft: The Power of Infrastructure Space (London: Verso, 2014), chapter 1.

32. Megacities and the United States Army: Preparing for a Complex and Uncertain Future (Fort Benning, GA: Army Strategic Studies Group, 2014).

33. "Future of War Conference 2017," YouTube, 8:27:31, 21 March 2017.

34. Chief of Naval Operations Adm John Richardson, white paper, "The Future Navy," 17 May 2017).

35. Megacities and the United States Army.

36. "Cities and Coastal Areas," United Nations Environment Programme, accessed 3 July 2014.

37. Kilcullen, Out of the Mountains, 29. 
38. For the purposes of this discussion, the term megacity is defined as an urban area composed of more than 10 million people. Jen Judson, "US Troops Need Training to Battle in Future Megacities, Marine General Warns," Defense News, 28 December 2015.

39. Judson, "US Troops Need Training to Battle in Future Megacities, Marine General Warns.”

40. Easterling, Extrastatecraft.

41. Megacities and the United States Army, 8.

42. Ian Klaus, Invited to the Party: International Organizations Evolve in an Urban World (Chicago: Chicago Council on Global Affairs, 2018).

43. Ian Klaus, "The U20: A Contemporary Diplomatic History," Diplomatic Courier, 31 October 2018. 


\title{
Information as the Cyberwar
}

\author{
Matthew J. Flynn, PhD
}

The Marine Corps has recently emphasized information as a key warfighting function. In step with this mandate of joint doctrine, the Marine Corps has stood up a deputy commandant for information (DCI) and established a MEF Information Group (MIG) at the three Marine Expeditionary Forces (MEFs). These moves represent a timely response to a threat environment where access to information has become a crucial element of warfighting. The cyber component to this dynamic confirms both the DCI and the MIG as needed entities given the trajectory of the ongoing and still unfolding cyberwar arena. Experts examining cybersecurity have long warned of the primacy of information as a means of shaping that battlespace. A review of this literature largely validates many of these predictions, affirms the Marine Corps' effort in this regard, and sets the stage for the next level of thinking that must occur. The cyberwar has indeed arrived, and now the focus of attention must address how the Marine Corps' efforts tie into the larger strategic information environment.

Today, too many threats and vulnerabilities, perceived and genuine, render cyberspace a warzone. Books such as David E. Sanger's The Perfect Weapon: War, Sabotage, and Fear in the Cyber Age (2018) and Fred Kaplin's Dark Territory: The Secret History of Cyber War (2016) portray many ominous developments in cyberspace. In this view, those resisting American global leadership have successfully used online access to steal intellectual property to potentially erode the combat arms and industrial advantage the United States enjoys. These attacks netted the plans for the Lockheed Martin F-35 Lightning II aircraft and data mined from health care systems to the U.S. government's Office of Personnel Management (OPM) tracking the personal information of federal employees. Furthermore, these adversaries can use cyberspace to strike vital infrastructure abroad and do so while remaining geographically distant_all while denying their role in such an attack. The United States struggles to respond due to the 
difficulty of attribution in that domain, which masks the involvement of perpetrators in any cyberwar.

The threats the United States faces in the cyber domain appear overwhelming, but not really much has changed since Richard A. Clarke and Robert Knake published the same warning of cyberwar in 2010. In Cyber War: The Next Threat to National Security and What to Do about It, the authors sounded the alarm and recommended government action to shore up cyber vulnerabilities and ward off many serious threats. They would be disappointed in what has come to pass since then. According to Kaplan, these vulnerabilities persist and the prospect of war reaching beyond cyberspace because of actions in that domain does as well. Shane Harris adds to this concern in @WAR: The Rise of the MilitaryInternet Complex (2014). Harris follows many of the same cyber threats defining the war that Clarke, Kaplan, and Sanger identify, but he warns against a call to arms that put the U.S. government at the helm of all things internet. Harris contends that an alliance between the U.S. military and the internet complex would be inimical to American democracy, although just how that would be the case, and what to do to counter threats, is where Harris ended his book.

Other authors have raised similar concerns about government overreaction and therefore overreach in terms of making cyberspace a warzone. In Cyber War versus Cyber Realities: Cyber Conflict in the International System (2015), Brandon Valeriano and Ryan C. Maness declare that overreaction to cyber events that fall well short of a definition of war make war more likely. Paul Rosenzweig said something similar in Cyber Warfare: How Conflicts in Cyberspace Are Challenging America and Changing the World (2013), when he stressed the online vulnerabilities facing liberal societies. Rosenzweig maintained that choices have to be made to achieve better security on this rapidly evolving platform, but he cautioned against a rush to action. P. W. Singer and Allan Friedman's Cybersecurity and Cyberwar: What Everyone Needs to Know (2014), continues this retreat from ascribing war as the defining aspect of cyberspace. The authors present a basic overview of online realities to help one better understand cyberspace and thus have less fear of cyberspace. Well-informed policy makers will no longer be disconnected from the technology they are supposed to govern via sound policy decisions. In this way, the chances of war are reduced. More recently, Martin C. Libicki, in Cyberspace in Peace and War (2016), details the real but not dire threats in cyberspace.

At a minimum, these experts call for more reflection before declaring cyberspace a warzone. That calm can help ensure that information does not become the means of war in the cyber domain. The possibility that mere access to everexpanding content could reshape our understanding of war echoes a caution from long ago. John Arquilla, a professor at the Naval Postgraduate School, in 
conjunction with David Ronfeldt, raised this issue of information warfare as early as 1993 in an article titled "Cyberwar is Coming!" for the journal Comparative Strategy. Writing in the wake of the First Gulf War about the prospect of "information-related conflict at a grand level between nations and states," this "netwar" meant the ability to promote "dissident or opposition movements across computer networks" (p. 144). War after 1991, they wrote, will diminish between states in favor of a "global civil society," and this transition will mark "the next great frontier for ideological conflict" (p. 145). Libicki gets close to this when he wrote in an earlier book-Conquest in Cyberspace: National Security and Information Warfare (2007) — that an "open approach to cyberspace" may allow one to "extend their influence and the influence of their values" online. This "friendly conquest" via cyberspace is preferable to some sort of hostile takeover of the domain because a "closed" approach forfeits the draw of more "attractive systems" (p. 3). In other words, overt conquest would defeat the very premise of connectivity as a public good answering to democratic norms.

The online war over values as information becomes an increasingly contested commodity via an "open" internet, and this dimension of the discussion of cyberspace merits much more explication. Yet, this potential is lost in the conclusions of many authors who argue that cyber does not represent a war unto itself. Rather, it augments existing acts of war. For example, Erik Gartzke, in his 2013 article "The Myth of Cyberwar: Bringing War in Cyberspace Back Down to Earth," writes in International Security:

Cyberattacks are unlikely to prove particularly potent in grand strategic terms unless they can impose substantial, durable harm on an adversary. In many, perhaps most, circumstances, this will occur only if cyber war is accompanied by terrestrial military force or other actions designed to capitalize on any temporary incapacity achieved via the internet (p. 43).

The dismissal of a "grand strategic" impact in cyberspace neglects any possibility of a decisive informational exchange online. Instead, for writers like Gartzke, conventional military force matters most. Derek S. Reveron agreed when he summarized these various thoughts found in a collection of essays in a book he edited titled Cyberspace and National Security: Threats, Opportunities, and Power in a Virtual World (2012). In his conclusion, he writes, "it is unlikely that cyber can exist as the sole source of coercion or can live up to classic definitions of war that encapsulate violence" (p. 230). Such thinking rests on an understanding of war as primarily a violent act coming at the hands of a military recognized by state authorities to wage this war.

Without violence, no war is found in the cyber domain. Instead, labels such 
as crime or espionage capture the ongoing competition there. In Thomas Rid's Cyber War Will Not Take Place (2013), he casts this need for violence firmly in the tradition of Carl Von Clausewitz. Rid paraphrases one of the central tenets of the Prussian war theorist's examination of war: "All war, pretty simply, is violent" (pp. xiv, 1-2). War seeks out physical force as a means to break an opponent's will and net political gains. Rid argues that without the violence, the strife in cyberspace presents sabotage and subversion as the mainstay of conflict in that domain. In Rid's estimation, this reality is a far cry from war.

Other experts reject the view that no war is found in the domain because violence does not lurk there. Some declare a war is afoot because use of force remains prominent, even if the violence does not kill people. Specialists debated this distinction in a series of six articles in a cyber round table section, published in the Journal of Strategic Studies in 2013. In one entry, John Stone writes, "Acts of war involve the application of force in order to produce violent effects. These violent effects need not be lethal in character" (p. 107). Force defines war, not the cost in lives. Timothy J. Junio essentially agrees, writing in the same section that "if cyber war happens, it will be extremely costly even if not lethal" ( $p$. 132). Junio concludes that, given the assumed stakes of the struggle there, war is the best characterization.

The pushback to Rid reflects the unease of too many with an understanding of war as divorced from physical violence. Many experts still find this familiar Western definition of war in cyberspace by tying cyber events to traditional manifestations of war in the other domains of land, sea, air, and space. In looking at cyber operations across multiple domains, they neglect the competition over ideas that also defines conflict in cyberspace as a function of information that is a standalone conflict in its own right. Even the Marine Corps' recent emphasis on information as a warfighting function does not allow for this consideration of "netwar," as Arquilla labeled the exchange of information online. But cyberspace offers a new point of departure for information to assert itself as a key frame of reference for interaction among states, producing a war over competing narratives. In this sense, even without violence in the cyber domain, war is a necessary label to better understand the ongoing conflict.

To further evaluate this characterization, one must come to terms with the expression of cyber ideology as an end to warfare as strictly determined by bloodshed, but it is an acknowledgment of war in the cyber domain nonetheless. As the Marine Corps looks to better engage in information operations (IO) in a cyberage, it would do well to remember that the technological achievement of cyberspace means that coercion now defines the cognitive reality in that domain as a warzone and as a desired point of state equanimity. Embracing that ambiguity avoids waiting for a cyber strategy to allow familiar government 
controls to overtake the cyber domain, something Alexander Klimburg drew attention to in his book The Darkening Web: The War for Cyberspace (2017).

Waging a successful fight via the DCI leads one to align IO efforts with the U.S. national cyber policy of preserving and advancing an open internet. A digital space online allowing information exchange free of government oversight serves an operational mandate with strategic implications. The U.S. Marine Corps' messaging campaign advances the ideas of a standalone war in cyberspace as much as it also enhances the Corps' operational capabilities. More importantly, this dual impact reinforces the Western ideological stand in cyberspace as a free informational exchange across the internet. Restrictive regimes such as Russia, China, North Korea, and even U.S. allies such as Saudi Arabia fear openness as an invitation to internal dissent due to a mere exchange of information and have to respond to the potential of cyber rebellions born of the intellectual confrontation in cyberspace, much as was the case when the technology first emerged. Going forward, the Marine Corps can help reverse the fear of too much information online, a mind-set currently gripping the U.S. public. Those seeking to restrict access must wage this battle for control; those believing in a common accord across humanity must do everything they can to maintain the current cyber environment in democratic societies, which encourages the free exchange of ideas and less restrictions of this freedom of speech on the internet. 


\title{
The Bomb and the Trolley Assessing China's Geopolitical Challenges
}

\author{
Guillaume Lasconjarias \\ Senior Researcher, NATO Defense College, Rome, Italy
}

Faked in China: Nation Branding, Counterfeit Culture, and Globalization. By Fan Yang. Bloomington: Indiana University Press, 2016. Pp. 300. $\$ 80$ (hardcover); $\$ 30$ (paperback); $\$ 29.99$ (e-book).

Chinese Nuclear Proliferation: How Global Politics Is Transforming China's Weapon Buildup and Modernization. By Susan Turner Haynes. Lincoln: Potomac Books, an imprint of University of Nebraska Press, 2016. Pp. 198. \$29.50 (hardcover and e-book).

Prestige, identification as a threat, and modernization: at first glance, this triad could help frame the questions and discussions about the nature, consequences, and shape of China's rise. From a Chinese perspective, the country has to recover its rightful place, of which it has been deprived because of the "unequal global relations of power" (Fan Yang, p. 20) stemming from the enduring "perfidy of great powers" (Turner, p. 2). This very topical narrative, which justifies China's policies both domestically and internationally, sees nationalism and the buildup of a strong national identity as a way to move on from the past and stand up against the West. Through modernization and a distinctive way of dealing with its own ideological fundaments, be it in the social, economic, or military domain, China's objective is - according to the leader of China, Xi Jinping-to stand "more firmly and powerfully among all nations around the world and make a great contribution to mankind." Of course, this has consequences and can be the root cause of tensions, misunderstandings, and miscalculations.

Two recent books, Fan Yang's Faked in China and Susan Turner Haynes's 
Chinese Nuclear Proliferation, address-with differences of perspective and scope-how China copes with a globalized order where it has to struggle to find its place. Both books underline how difficult it is, in a world shaped by strict international norms in the economic and security domains, to chart a genuine course of action without appearing to be forced to abide by someone else's-in this case, the West's - set of rules. Interestingly, in two completely opposite areas - the manufacturing of consumer goods and the nuclear arsenal-both authors agree on the importance of building a genuine identity for the contemporary Chinese nation-state as a remedy. Fan Yang addresses the challenges that China has faced since its accession to the World Trade Organization in 2001namely, the determination to refute the accusation of being nothing more than a country that "makes and fakes," given the strong and deeply rooted tradition of counterfeit practices in China (Fan Yang, p. 18). Turner, in her essay, explores the expansion and modernization of China's nuclear arsenal, with a particular focus on the past two decades, and she tries to explain why, at a time when the other nuclear nations are reducing their arsenals, China has to pursue "qualitative and quantitative advancements in its nuclear force" (Turner, p. 2). Thus, even if the two books seem at first glance to have very little or nothing at all in common, they nevertheless both address how China uses every possible lever to secure its place in the world.

Faked in China discusses the tensions caused by the persistence of counterfeiting and the efforts of the Chinese state to put an end to it and develop a new image. Using the intellectual property rights (IPR) regime as an example, Yang argues that the "nation's global reputation remains that of a thief," which calls for a political response and a true public relations campaign (Fan Yang, p. 3). Based on extensive material — and building on multiple case studies taken from different areas and related to popular culture (e.g., mobile phones, the film industry, or the fake Apple store in Kunming), Fan Yang explains that the official response has been to create a narrative (Fan Yang, pp. 12-13). This narrative change is encapsulated in the slogan: "From Made in China to Created in China," which tries to upgrade the profile of the nation from a pure manufacturer to a producer of goods (Fan Yang, p. 54). Fan Yang constantly examines how the official political line and ideological statements justify the decision to create a national brand, while at the same time globalization floods the Chinese marketplace and the people's mind-set. This rebranding is another attempt by China to declare its independence from the West, while at the same time participating in globalization:

After all, the crisis of "Made in China" is a crisis of authenticity in that the global imaginary of the brand has destabilized the state's "natural" claim to the nation. It is by resorting to a global-national imaginary-one that simultaneously corre- 
sponds to the global consumer-citizen and conforms to the financializing temporality of the brand - that the state is able to reconstitute itself as an agentive force in steering the nation toward an IPR-friendly future. (Fan Yang, p. 62)

The author argues that what is at stake is the offset between the state and the nation, which leads to an almost impossible reconciliation "between an internalized pressure to adhere to the mandates of global modernity and the continuing claims to the national" (Fan Yang, pp. 169, 200). In this sense, globalization is a catalyst that can exacerbate tensions, and Fan Yang's book helps us think about culture as a manifesto that is often underestimated.

Chinese Nuclear Proliferation tackles the contradiction—schizophrenia?between the official declarations of China as a signatory on the Treaty on the Non-Proliferation of Nuclear Weapons, which has always "emphasized a desire for the complete prohibition and thorough destruction of nuclear weapons," and its reticence to cooperate in multilateral nuclear disarmament or halt the expansion of its arsenal (Turner, p. 5). Exploring in-depth the nature of deterrence (chapter 1) and comparing China's force structure to those of the principal nuclear actors (chapters 2 and 3), Turner argues that what is at stake is the influence of America and looks at how changes in geopolitics trigger changes in practice (Turner, p. 91). Chinese officials, scholars, and the military share the same idea that U.S. modernization is a destabilizing factor, and China is attentive to situations that could trigger a nuclear conflict (Turner, pp. 99, 105). So this kind of escalation game goes further than the mere pursuit of prestigefor a domestic and international audience-even if it provides more credit to the country (Turner, p. 127). Turner's overview, especially, helps outline the possibilities of limiting, and even stopping, the Chinese buildup through concrete and realistic proposals-mostly aimed at American policy makers (p. 143).

Overall, both books are a good read as they share three common features. First, they focus on key contemporary issues, affecting not only China's overall security posture (and being a trustworthy economic actor goes beyond the simple question of increasing GDP) but the entire Southeast Asian region. Second, both volumes extend the discussion to issues that have burgeoned in recent years - counterfeit culture or the nature of the Chinese nuclear strategy—and can provide additional answers to those seeking better understanding of the underlying dynamics that accompany Chinese courses of action and strategies. Finally, as both authors, in their different ways, tackle the imagined and perceived contention between the United States and China, they can generate discussions on the reality of the so-called rise of China and the tensions within a country struggling with Third World issues while aspiring to be a future hegemon.

Despite their impeccable outline and in-depth analysis, both books suffer 
from minor faults. Fan Yang's book is very conceptual and a reader unfamiliar with cultural studies - and the concept of cultural imperialism in particularhas some hurdles to overcome. On the other hand, some aspects of Turner's essay could have been more fully developed, and it would deserve a second edition, taking into account the latest developments in U.S. nuclear strategy and how this responds—or not—-to the criticisms of some Chinese analysts.

\section{Note}

1. "Full Text: China’s New Party Chief Xi Jinping's Speech," BBC News, 15 November 2012. 
The Soviet-Israeli War, 1967-1973: The USSR's Military Intervention in the Egyptian-Israeli Conflict. By Isabella Ginor and Gideon Remez. Oxford: Oxford University Press, 2017. Pp. 400. \$37.50 (hardcover).

Observers are rightly concerned about the "new" Russian style of warfare. This form of warfare has been practiced by Russia in Crimea and Ukraine and threatened other parts of Eastern Europe. It has been variously called hybrid warfare, new war, or next-generation warfare. It all amounts to the same thing: the use of propaganda and deception, maskirovka (military deception), dezinformatsiya (disinformation), cyberwarfare, deploying conventional troops with no insignia, diplomatic démarches, and conventional military exercises external to the state being threatened. In Russian military literature, of course, the authors claim that it is what the U.S. and NATO forces practice against them, and they supposedly disavow any doctrine of "hybrid" or "new" warfare. But such claims harken back to the Soviet tradition of developing the public version of their military doctrine in response to what its ideology claimed the United States and NATO were planning to do.

Whatever the terms used, the Russian practice of "hybrid" warfare is not new, but a more sinister evolution of Soviet doctrine and practice used during the Cold War outside the European theater. Isabella Ginor and Gideon Remez's book The Soviet-Israeli War, 1967-1973 gives readers an unprecedented, granular look at how the Soviets supported the Egyptians during the six years between the 1967 Six-Day War and the 1973 Yom Kippur War. By support, the authors mean far more than the conventional narrative of that period of time, which depicts the Soviets providing the Egyptians with technicians and advisors, particularly during the War of Attrition (1969-70) before President Anwar Sadat was reported to have kicked Soviet advisors out in 1972, moderating Egyptian behavior. Rather, the authors demonstrate that the Soviets actively trained the Egyptians with then-modern weapons to counter Israeli military and technical superiority; doctrines to use modern air defense systems to blunt Israeli air strikes; intensive training to help the Egyptian army learn how to conduct effective canal-crossing operations as the necessary precondition for 
success in the 1973 war; and with the organs of state propaganda and diplomacy the Soviets used to seek political cover for the Egyptians until they could get ready for the final confrontation with Israel. The Soviets did this with the support of approximately 50,000 Soviet military and civilian personnel during this period, with occasional direct combat between Soviet and Israeli forces intentionally done to bolster Egyptian morale and to demonstrate the qualitative superiority of Soviet advanced arms. They arrived in civilian clothes, sometimes whole units, and donned Egyptian uniforms, with much of the equipment they would use either directly against the Israelis (antiaircraft missiles and fighter planes) or to help train and educate the Egyptian military. Many, if not most, of these "internationalist" forces were never officially recognized until the 1990s, or allowed to publicly share their stories, and then only for a brief period of time until Vladimir Putin clamped down.

The book is organized into four major parts that cover the period in 31 chapters. The text reads well as a forensic investigation into the events against the backdrop of the conventional narrative of what happed during that time. While the Six-Day War and Yom Kippur War have been researched and analyzed thoroughly, the period between the wars has not, leaving several sources with vested interests in their version of events to create the generally accepted narrative of that period that survives until today. As no American and few Western journalists were allowed into Egypt under conditions of censorship, and none in combat zones, the media reports that came out of were typically Egyptian and Soviet, reflecting official government views but unreliable in whole or in part except as timelines for cross-checking against other sources. Israeli news sources were only slightly more useful, as military censorship severely limited what could be reported. As a result, the conventional narrative overly emphasizes diplomacy while allowing these vested interest sources to set the script. Among these sources, two seem to predominate: the books of Egyptian news editor and politician Mohamed Hassanein Heikal and Henry A. Kissinger. Their books, for different reasons, gained prominence in the narration of the opening and closing phases of the period and are the primary citations for many other works on this period.

The authors use a wide array of sources as attested by the notes section of more than 100 pages and a bibliography of 16 pages. The authors use media sources of various reliability, official government records, including the archival series Foreign Relations of the United States (FRUS), the recently declassified testimonies before the Israeli commission of inquiry on the Yom Kippur War (the Agranat Commission), declassified intelligence analysis (where available), and some limited archives of Russian foreign ministry. Though it was widely believed that Russian archives were thrown open to Western scholars after the Cold War, the reality was quite different. Few organized records were actually 
kept and many classified archives were intentionally destroyed. The Politburo (the Soviet Communist Party governing authority) conducted its decision meetings in the Walnut Room in private with no recordings, and only then meeting formally with a general declaration of activities ambiguously stated in the full session (p. xxiii).

The most significant, and novel, sources the authors use is of Soviet veterans' memoirs and recollections. These narratives only became available with the limited opening of glasnost in 1988 and into the early years of post-Soviet Russia. These "Egyptian" veterans "demanded recognition-both for their fallen comrades and for themselves - as fighters in, indeed heroes of, a full-fledged though undeclared foreign war" ( $\mathrm{p}$. xxv). They did so through veterans' clubs, small-scale publications and pamphlets, newspaper articles, and later with the internet. The authors began tracking this literature in 1989. When they needed to fill in gaps or make links not obvious from the emerging literature, they conducted telephone interviews with many of these veterans until the rise of Vladimir Putin made it too dangerous for these veterans to respond anymore. To their credit, the authors are the first to introduce this oral history into Western scholarship.

In addition to a stellar investigation into the interwar period, and the historical precedents to contemporary Russian hybrid warfare, there are other good reasons to read this book. First, the authors' methodology and historiography provide sophisticated methods to assess the credibility and reliability of publicly available evidence. The authors have solid journalistic credentials, having worked for years in media venues. Once they began this joint research project, they established standards for assessing the credibility of archival sources, memoirs, journal pieces, and oral histories to include, and where nothing else availed, Russian veteran poetry. Not only journalists but also scholars should take note of their approach, which they outline early in the book on how to assess and weigh the degrees of credibility and inferential force of the variety of official, propagandistic, and oral evidence. Their account of these six years provides a needed corrective to the breezy conventional narrative of the interwar period while illuminating how far the Soviet Union was willing to go in militarily supporting its allies in the teeth of a nuclear-armed adversary, Israel, backed by a nuclear-armed superpower-the United States. It seems beyond cavil that U.S./NATO officials should carefully assess the willingness of Russia today to project power into Eastern European countries while risking nuclear confrontation.

Both authors are associate fellows of the Harry S. Truman Research Institute at the Hebrew University of Jerusalem. Dr. Isabella Ginor was born in Ukraine and came to Israel in 1967, working as a journalist and researcher on the Soviet Union for a variety of media outlets until her appointment to the Truman 
Institute in 2001. Gideon Remez served in the Israeli Army's paratroops and saw action in the 1967 war as a reservist, and he served as a war correspondent in the Suez Canal theater of the 1973 war. He was a journalist for the Voice of Israel for 36 years, and was chief editor of the foreign news broadcasts, before joining the Truman Institute in 2009. They have jointly published a variety of scholarly articles on Soviet involvement in Middle East conflicts, and their first coauthored book, Foxbats over Dimona: The Soviets' Nuclear Gamble in the SixDay War (2007), won the silver medal book prize of the Washington Institute for Near East Policy. This book builds on their methodology and extends it to the interwar period. It should be required reading for anyone interested in recent Middle East history and Russian military history and doctrine.

Mark T. Clark, PhD

Professor of political science and director of the National Security Studies program, California State University, San Bernardino; director of the CSU Intelligence Community Center of Academic Excellence; and president of the Association for the Study of the Middle East and Africa (ASMEA)

Restraint: A New Foundation for U.S. Grand Strategy. By Barry R. Posen. Ithaca, NY: Cornell University Press, 2014. Pp. 256. \$29.95 (hardcover); \$19.95 (paperback).

Barry R. Posen's Restraint: A New Foundation for U.S. Grand Strategy is a relevant and cogent look at the importance of exercising nuanced, cause-and-effect decision making in grand strategy development and the interconnectedness of the international security system. Posen offers a compelling case for a change in U.S. grand strategy toward conservation of American resources that could serve as a causative stimulus of international partner activity. As the Ford International Professor of Political Science and Security Studies Program Director at Massachusetts Institute of Technology (MIT), Posen artfully leverages his expertise writing this book (back cover). He holds an MA and PhD from the University of California-Berkeley and served as a consultant for the Rand Corporation. He was also an analyst for the Department of Defense and for the Center for Strategic and International Studies. After serving as an associate professor at Princeton, he transitioned to MIT where he has remained since. Restraint is Posen's third book.

Restraint is a book on the evolution of liberal hegemony as America's postCold War grand strategy. Posen simply defines grand strategy as "a nation-state's theory about how to produce security for itself" (p. 1). Posen outlines the pri- 
mary components of national security as sovereignty, territorial integrity, power position, and safety (p. 3). Of these elements, he argues that power position is the most critical because it is the sum of a state's capabilities relative to other states, which permit the defending of the individual components of national security against threats from other states (p. 3). America's power position and how it is impacted by the practice of either liberal hegemony or restraint becomes the key theme of Posen's argument. He posits that America currently exercises an ineffective strategy of liberal hegemony, which is costly and overprotective of America's current, but likely brief, unipolar moment (p. 24). He also argues that America should now transition to a grand strategy of restraint that would focus primarily on vital U.S. security interests and reduce global activities to geopolitical interests and maintaining the balance of power (p. 69). Using a simple and logical organization, Posen divides his delivery of concepts into three main parts. He begins with outlining the perils of liberal hegemony, makes his case for restraint, and closes with the presentation of a maritime-focused military strategy that would support a grand strategy of restraint.

Posen asserts that the United States currently exercises a strategy of liberal hegemony, which is hegemonic because it builds on and protects the power position of the United States and is liberal because it aims to spread and protect Western, Americanized democratic values (pp. 5-6). Though many of the ideas behind liberal hegemony have bipartisan support and hold strong in international politics, Posen argues it has performed poorly as a grand strategy during the last 20 years (p. 24). The direct costs of liberal hegemony have been mostly accrued through a global increase in U.S. military activity not directly attached to any of the components of national security. The author attributes this to the global ambitions of an economically superior unipolar power that can "afford" to militarily overwhelm potential challengers to a degree that they will not even try to compete (p. 5). In addition to direct costs of multilateral international relationships when exercising liberal hegemony, the United States bears the costs and consequences of poor partnerships. This includes the financial hardships of international organizations such as the NATO, which brings with it what Posen refers to as "cheap riders" and "reckless drivers" (pp. 35-39). Here, Posen outlines how the dynamics of liberal hegemony allow cheap riders, such as Japan, to provide less than their "fair share" of gross domestic product (GDP) for their defense because the United States will carry the weight (p. 35). Posen defines reckless drivers, such as Israel, as countries that do the wrong things, such as take bold actions that may harm U.S. interests while the United States fails to hold them accountable (p. 44). These issues and more have great potential for impact and liability to America's power position. Although Posen acknowledges that his thesis receives criticism for downplaying the complexity of international politics and the many plausible interconnections among vari- 
ous issues-economics, political, military, social, and technological-he justifies this narrowing with the argument that the knowledge of interconnectivity is not useful in the real world of strategy, which contains high amounts of scarcity and costs (p. 3). This disclaimer is valid, but he fails to pay adequate attention to the myriad of political and military benefits of this increased post-Cold War global activity, which is taking place in the recently developed environment of globalization - the one that he criticizes. The minimizing of complexity does not make the book a less valuable read, but it does leave vital counterfactuals and critical causal chain factors unaddressed.

When making his case for restraint as the new U.S. grand strategy, Posen focuses on reducing what he labels "the pernicious consequences of the past twenty years of global activism" (p. 69). While he does not argue for full isolationism, he does advocate for a healthy decrease of global-security related multilateral military activities and a refocus on U.S. security interests. Posen provides a restraint strategy for four global regions: Europe, East Asia, the Middle East and Persian Gulf, and South Asia (pp. 69-134). Though grand strategy primarily addresses external threats, he argues exercising restraint could bolster U.S. domestic stability by contributing to U.S. economic health as a result of improving the efficiency of national resource allocation (p. 70). Posen recommends a phased reduction in U.S. political commitments and military deployments with the ultimate goal of placing responsibility for the security of allies back on the allies. He further argues that Cold War alliance organizations, such as NATO, should be ended and that the United States can rely on its advanced and secure retaliatory force for protection from potential nuclear attacks from other nuclear powers. Ultimately, through use of the four regional case studies, Posen supports his argument that in grand strategy less-is-more because morecosts-more.

Posen offers a military strategy that emphasizes maritime activity and the importance of the command of the global commons (p. 71). He posits a maritime military strategy would allow for a persistent forward U.S. presence that influences global communications and the movement of goods and information. The United States currently enjoys command of the seas, command of the air, and command of the space domains. Posen asserts that a grand strategy of restraint aims to preserve U.S. influence in Eurasia and to address new nontraditional, geopolitical security threats at the lowest political, military, and economic cost (p. 135). He believes a maritime strategy best serves this aim, thus he provides a recommendation of force structure, service reductions, and nuclear infrastructure that would support a global restraint strategy for no more than 2.5 percent of GDP (p. 135). Posen believes his military strategy would allow for up to 20 percent savings in military personnel cost while still addressing counterproliferation and global presence but omits the repercussions of such 
significant decrease in land armies (pp. 135-63). The threat of rogue states and the unstable status of states is a very relevant and real phenomena today of which both liberal hegemonists and conservative realists share concerns. This threat remains unsatisfactorily addressed by this grand strategy proposal.

Posen's Restraint is a well-organized and succinct analysis and proposal for transition to a realist grand strategy to protect America's power position. His arguments use narrow definitions of security studies terminology but with a purpose of recognizing that international politics is complex and all plausible causal chain events could never be accounted for in a grand strategy. While some counterfactuals and considerations of liberal hegemony remain partially omitted, Restraint is compelling and provides a proposed path for economic recovery from two decades of global political-military overextension. Posen argues a U.S. grand strategy of restraint is possible, and he tells the reader why it should be employed.

Posen's audience appears to be conservative restraint advocates, policy makers, diplomats, strategists, and security and military practitioners, of which all could benefit from the reading of this book. Policy makers and diplomats may advance their knowledge and understanding of the nuanced influence military activities abroad have on the international security environment. Strategists from both the liberalism and realist camps may glean deep considerations for and against either approach and military personnel can gain insight as to their place and role in international security beyond the battlespace.

Maj A. B. Christman

Command and Staff College

Marine Corps University

Over the Horizon: Time, Uncertainty, and the Rise of Great Powers. By David M. Edelstein. Ithaca, NY: Cornell University Press, 2017. Pp. 220. \$45.00 (hardcover).

It is not often you read a book that begins a new research agenda in international relations, but that is what David M. Edelstein's newest work, Over the Horizon, accomplishes. Over the Horizon makes a substantial contribution to the study of great power politics, incorporating the concept of time as a critical variable that explains how great powers manage the rise of other states. Edelstein frames the book with a puzzle that has long troubled realists in the current era: Why does the United States pursue economic cooperation with China, thereby aiding its rise in the international system? Why does the United States 
not instead compete with China and attempt to limit its rise? The theory that Edelstein develops is intuitively appealing, in no small part because it appears to answer the China question both completely and precisely. He argues that great powers must choose between the short-term gains from cooperation and the long-term costs of aiding the rise of a potential rival, while rising powers must decide whether to pursue strategies that are aggressive in nature or accept the status quo. It is then the great power's uncertainty about the intentions of the rising power that open up space for cooperation: when a rising power chooses nonaggressive grand strategy (thereby maintaining uncertainty about its longterm intentions), and the great power has short-time horizons (and therefore prioritizes immediate gains), the two are likely to cooperate. However, these are both necessary conditions; absent either of these factors, we should expect to see competition.

Edelstein's principle contribution to international relations here is obvious: extant theories of state behavior largely ignore the role that time horizons play in great power politics. He begins an important conversation about the ways in which states interact over time, anticipate the shadow of the future, and how grand strategy can change as states rise, decline, and evolve. As countries' economies change and mature, the relative value of cooperation also changes. Meanwhile, as a state's ability to project power changes, they feel more or less comfortable signaling aggressive intentions. Edelstein leads the way in asserting that time horizons matter when great powers interact and that managing expectations and intentions is an important part of a rising power's grand strategy.

There are areas for improvement and clarification, however, in the theoretical framework. Edelstein presents the theory as a rationalist argument for why great powers see incentives to cooperate with rising rivals. However, the book's discussion of time horizons imports many nonrational explanations for why hegemons may be uncertain about a rising power's intentions, including leader psychology, identity, and outright persuasion (pp. 48, 61, and 73). Without clear and rationalist criteria for determining a state's time horizons, the theory runs the risk of being unfalsifiable; a great power's decision to cooperate can always be explained post hoc because a leader was persuaded in some way by their counterpart, but the ability to predict cooperation ex ante is minimal. Further research should look at clearly articulating the circumstances under which we expect great powers to have short- versus long-time horizons and clarify the ways in which rising powers seek to reassure great powers of their benign intentions, as well as when we expect those reassurances to be successful.

Further, the book's empirical chapters raise significant questions about what counts as a rising power. While the four historical case studies are exceptionally well-researched and thorough, three of them begin when the identified "rising" 
powers are already essentially at parity with the other power in the international system. By 1871, Imperial Germany had already soundly defeated France in the Franco-Prussian War and had one of Europe's largest economies. By the turn of the twentieth century, the United States was already exercising essentially unilateral control over the Western Hemisphere; Edelstein acknowledges that "the evidence reveals that the United States did little through its behavior to try to shape British beliefs about its intentions-it saw little danger in acting assertively sooner rather than later" (p. 73). And by the end of the Second World War, the Soviet Union is heavily militarized, an enormous threat to Europe's central front, and just four years away from the development of nuclear weapons. In all three of these cases, engaging an emerging power earlier is no longer an option by the time Edelstein begins his exploration, as the costs associated with conflict are exceptionally high. The choice left to great powers in these three cases instead relies upon a different set of choices and logic-cooperate with a fellow great power, or risk the destruction of the state through conflict. Additional works would benefit from refining the criteria by which Edelstein selects his cases: how can we identify, before they become great powers, which states are rising (and therefore know the universe of cases); at what point do rising powers become great powers (and how this changes the strategic logic of extant powers); and how powerful do rising states have to be before extant powers begin to operate according to his theoretical logic?

The theoretical framework offered by Edelstein, and the intuition behind it, are both parsimonious and compelling. It adds a valuable component to our understanding of great power politics, and it raises more questions than it asks. This is the signal of an exciting new research agenda, and an important contribution to the study of international relations. Intentions and signaling remain an underexplored area of political science, and Edelstein's work sets the stage for fruitful and insightful study. Future work on great power politics will find this book a must-reference work, and students of international relations will benefit from a careful reading, as there are dissertation topics abound layered within this book.

Carrie A. Lee 1

Assistant Professor, Department of International Security Studies, U.S. Air War College

\section{Notes}

1. The views expressed in this book review are those of the author and do not reflect the official policy or position of the U.S. government, the Department of Defense, or Air University. 
No Miracles: The Failure of Soviet Decision-Making in the Afghan War. By Michael R. Fenzel. Stanford, CA: Stanford University Press, 2017. Pp. 192. \$65.00 (hardcover).

Michael Fenzel's No Miracles explains why the Union of Soviet Socialist Republics (USSR) invaded Afghanistan in 1979, how it conducted the war, and why it failed to achieve its strategic objectives. Focusing on the politburo's decision making, he begins with several puzzling questions about Soviet policy: Why did the USSR enter this conflict despite lacking a realistic path to victory? Why did it fail to change its strategy or more accurately read the realities in Afghanistan? Why did the Soviet leadership remain in this war for so long, even as the situation regressed and the costs mounted? His answers do not simply summarize why the Soviets lost this war but illuminate the mechanics of why its policy making apparatus repeatedly failed to assess the situation accurately and adapt.

Fenzel organizes this book into concise chronological chapters that show the development of Soviet policy in Afghanistan and highlights key failures. For sources, he draws mainly on the politburo archives and interviews with former Soviet officials from the Wilson Center's Cold War International History Project. He peppers the narrative with large quotations from these sources, which provide the reader with a vivid sense of the give-and-take of politburo debates.

Fenzel's thesis centers around three major factors behind the failure of Soviet decision making in Afghanistan: dysfunction in civil-military relations, the rapid succession of the Soviet leadership, and the leaders' concern with international credibility. Of these, Fenzel focuses most on civil-military relations as a cause of poor decision making. He argues that Leonid Brezhnev, Konstantin Chernenko, and Yury Andropov consistently excluded military experts from key decisions, especially the fateful choice to topple Nur Mohammad Taraki, who was president and prime minister of Afghanistan, and invade Afghanistan. The military saw little hope of victory in Afghanistan and viewed it as a distraction from preparing to fight the United States, but the Soviet leadership hardly sought their advice on these matters. Furthermore, Soviet leaders refused to seriously pursue other avenues of stabilizing Afghanistan beyond ordering the army to strike with greater intensity. This strategy proved counterproductive because it bolstered Afghan support for the guerrillas and damaged Soviet standing in the world. Fenzel successfully shows how the lack of civil-military coordination engendered the "failure to match ends and means," which is the core of Fenzel's understanding of the failure of Soviet decision making (p. 120).

The second key point in Fenzel's argument is that the rapid overturning of the aged Soviet leadership in the early 1980s created incoherence and drift in Afghan policy. Not only did the USSR experience three general secretaries between 1982 and 1985, but they also were old, ill, and largely incapable of 
dramatic action on foreign affairs. He argues that they had to consolidate power upon becoming general secretary, which precluded changing a failing Afghan policy lest they appear weak or unorthodox. Fenzel's third major point on Soviet decision making is that, as the war dragged on and the collapse of the Afghan government became more likely, the politburo became more concerned that total withdrawal would lead Soviet allies to view it as an unreliable protector. They also feared the encroachment of U.S. and Pakistani power if the mujahideen overthrew the government. Fenzel shows how a variety of misperceptions and delusions governed the intervention, including the idea that Afghan leader Hafizullah Amin was seeking to ally with the United States or that the impoverished and deeply religious Afghan society could be converted to socialism.

These three factors continued to hamper Soviet decision making even as Mikhail Gorbachev started a long process of withdrawal upon taking the helm in 1985. Gorbachev's domestic reform agenda required reducing tensions with the United States and cutting defense spending, so he believed he had to withdraw from a conflict he already viewed as hopeless. Nevertheless, like his predecessors, he had to consolidate his political position before acting quickly, and his tense relations with the military and orthodox Communists further slowed his attempts to end the war. Fenzel shows that Gorbachev ultimately made the fig leaf treaty that ended the war and that fit his broader foreign policy, even if the regime the USSR left in place did not last long.

In historiographical terms, Fenzel challenges existing explanations of Soviet defeat that focus on the U.S. role in backing the insurgency, shortcomings in Soviet military strategy, the failure of the USSR to seek a favorable diplomatic solution, and the weakness of the Afghan government. These factors may help explain why the Afghan adventure became a disaster, Fenzel claims, but they do not explain why the Soviet decision-making process was so flawed. For instance, he argues that the politburo asked the military to "deliver a tactical and operational victory in a strategic vacuum," showing that the civilian leadership had no strategic concept beyond repeatedly ordering the military to pummel the insurgency while stubbornly capping troop levels at 108,000 (p. 6). Fenzel pushes the historiography of this conflict and Soviet foreign policy in the 1980s forward by showing the more structural mechanisms behind the somewhat surface-level explanations of Soviet defeat.

Fenzel's historiographical critiques, however, occasionally create artificial distinctions between explaining the failure of decision making and explaining Soviet defeat in the war. For instance, he claims that the "emphasis on Afghan weakness is more a rationalization for Soviet failure than it is an effective expression of what truly went wrong" (p. 8). While the weakness of the Afghan government does not explain poor Soviet decision making, it must be considered an essential factor in the overall Soviet defeat. A more bal- 
anced historiographical account would create a less antagonistic relationship between existing scholarship and Fenzel's work by treating the study of failed decision-making processes as a complement to the arguments about the failure of the war itself.

Michael Fenzel is an active duty brigadier general in the U.S. Army who has also served on the National Security Council and as a fellow at the Council on Foreign Relations. His experience in military, policy, and academic worlds is reflected in this book, which speaks to the concerns of each of these realms. Historians will recognize its excellent use of sources and attention to historiography, military and civilian policy makers will value its relevance and applicability, and all readers will appreciate its brevity and clear expression.

No Miracles deserves a privileged place not just among works on Soviet policy in the Afghan War but among studies of executive decision-making and civil-military relations more broadly. In short, it is an excellent study of flaws that many organizations face in designing the policy process: the failures to think in the long term, realistically connect ends and means, adapt to new information, incorporate expert and/or contradictory viewpoints, and prioritize good strategy over bureaucratic infighting. Some of the problems in Soviet policy making were specific to the Soviet system, such as the succession of senescent dictators, but others could apply to policy making and civil-military relations in democratic governments. Indeed, scholars of the Vietnam War will find numerous parallels in this work between Soviet and U.S. decision making, including civil-military dysfunction, excessive optimism, and obsession with maintaining credibility with allies even as the conflict sapped that credibility. This book should be a priority read for scholars, military officers, and policy makers as the United States remains entangled in Afghan politics and security for the foreseeable future.

\section{Joseph Stieb}

PhD candidate in U.S. history at the University of North Carolina at Chapel Hill working under Wayne Lee. His dissertation, "The Regime Change Consensus: Iraq in American Politics, 1990-2003, " examines why the containment of Iraq came to be seen as a failure by the end of the 1990s and how this process shaped the formation of a regime change policy toward Iraq following the 11 September 2001 attacks.

Near Abroad: Putin, the West and the Contest over Ukraine and the Caucasus. By Gerard Toal. New York: Oxford University Press, 2017. Pp. 408. \$29.95 (hardcover). 
The current tension in relations between the United States and Russia widely predates the related headlines that plagued the 2016 U.S. presidential elections. It is not even the domestic scene within either power that has as much an influence as does their geopolitical peripheries in such a state of affairs. Gerard Toal's Near Abroad presents a critique of American and Russian geopolitics over the Caucasus and Ukraine, and the post-Soviet spaces' navigation toward Western or Eurasian political and economic integration. It is in the context of the 2008 Russo-Georgian War and the Russian intervention in eastern Ukraine following the 2013-14 Euromaidan demonstrations, which the book captures regarding the different perspectives on how Washington and Moscow responded to the crises (p. 14). More specifically, Toal's methodological approach to this contest involves diving into the subgeopolitical categories of fields, cultures, and conditions, where concepts such as spatial identity, military capabilities, and favored narratives play a key role in illuminating why Russia invades and why the United States responds.

Toal's book appropriately begins with chapter 1 debating why Russia chooses to invade its neighbors in the twenty-first century. While liberal and populist-realist narratives are introduced, they are seen as inadequate due to their focus on explaining geopolitics in revisionist or moralistic struggles. It does much injustice and promotes excitement to frame Russia's actions in the Cold War/George Kennan-style rhetoric of a primordialist desire in expansion and/or the reconstruction of the Soviet Union. Also dismissed is the over attribution of "hostile intentions to perceived competitors, emphasiz[ing] negative dispositions ... and discount [ing] ambivalent contextual factors" (p. 27). Toal's methodology reveals a double standard in such poor reasoning, pointing to American foreign policy vis-à-vis Iraq and the troubling logic of intervention or differing liberal norms in the Middle East as opposed to Europe. While the social shock after the collapse of the Soviet Union is recounted in the following chapter, it is supplemented by geopolitical visions of what a new Russia would look like emerging from the ruins: Westernizing, imperial, or strong (with a detailed table on pp. 72-73). Each category is engaged through the examination of key Russian figures and institutions that lobby for a particular post-Soviet state. Toal withholds attesting to any of these categories in light of proceeding chapters but does seem to lean on the idea of President Vladimir Putin projecting a revanchist agenda, one that seeks to flex Russia's strength but not necessarily through territorial expansion. This is backed by multiple sources where Putin has voiced his frustrations over the United States' "tearing up all the established rules and doing what it liked without regard to international law" after the 11 September 2001 attacks (p. 90).

One of the two important components to this study is Georgia and its 
struggle to preserve its territorial integrity in the face of separatist movements and foreign intervention. The U.S. role is illustrated by the efforts of then-President Mikheil Saakashvili to not only adopt and import American virtues of liberty and democracy but to mirror his own interest onto his patron's- the United States' - foreign policy. Yet when Georgian demands for absolute unification fall upon breakaway regions such as South Ossetia and Abkhazia, it is the latter that seeks the patrimony of a state they feel more culturally and historically related to: Russia. The end result is an inevitable clash between Russia and the United States in the form of a Russo-Georgian War, which Toal accredits to great powers backing smaller ones, and based off of this formula, a distant actor (the United States) practicing its campaign of promoting "democratic" rule on another near the periphery of another powerful actor (Russia). Bullets shot at Russian keepers may have provoked Moscow's mobilization, but Saakashvili's fishing for American support and gaining solidarity with prominent U.S. power brokers such as lobbyists and policy makers were enough for Moscow to see the Georgian conflict as an incursion on Russia's near abroad. Toal highlights that what began as an isolated Caucasus incident soon bloomed into a transnational affair when Saakashvili's American allies took an active interest in supporting Georgian victimhood after the nation-state's Russian invasion. Statements of solidarity like "today we are all Georgians" alluded to the dominant U.S. narrative that Russian aggression against smaller neighbors was also one against America and democracy as well (p. 127).

Due to the Euromaidan protests, Ukraine is the second puzzle piece to reconstructing the causes for the deterioration of U.S.-Russian relations since 9/11. While Russia's eastern neighbor, Ukraine, did not have a profound, Westerninfluenced leader like Saakashvili, President Viktor Yanukovych's refusal to pass pro-European Union legislation set off mass protests that drew a Russian response in the form of armed intervention that seized Crimea. Here Toal provides a variety of sources to explain the latter event, such as undoing a historical mistake (Nikita Khrushchev's illegal gifting of the region to Soviet Ukraine) and using state media outlets to widely broadcast the official ceremony for Crimea's reintegration to Russia. Interestingly enough, the motives for the initial seizure are openly pronounced in speeches by Putin and mirrored in local propaganda with two historical narratives: fighting off the fascist currents that caused the Euromaidan to break out violently and protecting Crimea's largely Russianspeaking population from the West's attempted enclosure of Russia (pp. 228-29). Like chapter 6 , the following chapter deals with Russian attempts to foment unrest in eastern Ukraine to resurrect a nineteenth-century region called Novorossiya (New Russia) that Russia could reintegrate based on historical and perceived ethnic arguments. The main actors here are various Russian nationalists of military, political, and intellectual background, whose agency was to 
work with pro-Russian oligarchs (supplemented by networks of activists, even "agitators") in the region to legitimize a campaign for separatism. Toal, however, uncovers the contingency plan's origins within Kremlin circles dating back to 2008 during Ukraine's bid for NATO membership, citing it as a lever to curb Kiev's turn to the West. But unlike Crimea, the Russian gamble on Novorossiya has not paid off with polls showing the majority of localities in eastern Ukraine seeing the project as a myth, having no basis for separatism, and the makings of Russian political propaganda (pp. 271-72). These opinions are regardless of one's ethnic and/or mother tongue, whether its Ukrainian or Russian.

The overarching theme of the influence of international institutions like NATO is crucial to the book's subjects of Georgia and Ukraine. The 2008 Bucharest Summit was a watershed moment in U.S.-Russian relations, where the United States publicly pronounced that one day both states would become members of the transatlantic alliance. In addition to American support for Kosovo's independence, both declarations were met with disapproval and warnings from Moscow. According to Toal, Russia's actions in 2008 and 2014 should be understood as a reaction to the West's encroachment on Russia's geopolitical interests in its near abroad. Conflict with Georgia was a result of South Ossetia seeking Moscow's protection and the death of Russian peacekeepers. The Euromaidan crisis spurred the fleeing of Yanukovych due to a growing and partially violent protest that demanded Ukraine turn toward the West with EU integration at the expense of regional cooperation spearheaded by Russia, the Eurasian Economic Union. A closer look reveals that Russian intervention was based on greater precedents other than a shared history with both post-Soviet states. When the United States backed the Euromaidan protestors and Saakashvili, Moscow interpreted this as Western designs seeking to destabilize regions in its immediate periphery, even drawing on comparisons to Iraq and Syria. The Kremlin's public declarations to fight fascism that had taken hold of Ukraine, for example, contained a favored narrative form and/or myth to legitimize an armed response. But in reality, such unrest in both post-Soviet spaces represented a security threat that in order for the status quo to return, the showcasing of Russian strength was a necessity.

If Near Abroad seeks to take a nonpartisan position and present the perspectives from both sides, then Toal certainly does a good job of it. He is not exclusively a Russian apologist or critic of American foreign policy. Rather, he boldly argues that the underlying problem plaguing relations between both actors is their practice of a "thin" geopolitical approach to third parties such as Georgia and Ukraine. Moral dichotomization and outdated Cold War approaches, if not stereotypes, continue to find fertile minds in the policy makers of both sides. Whereas history, culture, and proximity have hardened Moscow's insistence on having a say in the decisions its neighbors make, the United States and Western 
institutions like NATO continue to believe in the necessity of their missions and values penetrating those unintegrated areas. This begs the question of whether NATO still continues to function in a Cold War approach to international peace; namely, expanding its portfolio of clientele, even if unofficially.

Toal's monograph is an exemplary contribution to the field of political science and how to approach the politics of great world powers. But as his conclusion states, real coexistence between the United States and Russia can only be attained through "thick" geopolitics, where both sides understand and respect their spatial relationships (p. 279). If the United States desires to spread democracy for the better of the world community, then it should abandon all standoffish tactics that raise red flags in Russia, such as Saakashvili's Bonapartism or brokering relations with select oligarchs in Ukraine (p. 299). Russia too should rethink its reliance on private interest individuals who espouse strong nationalist sentiments on state policies, as supporting or annexing conflict zones has shown a noticeable financial strain. For Toal, the supporting of free and democratic institutions and practices serves a better, less antagonistic practice that avoids armed confrontations and promotes better relations with foreign powers.

Martin J. Kozon

PhD student

University of Wisconsin-Milwaukee

Military Service and American Democracy: From World War II to the Iraq and Afghanistan Wars. By William A. Taylor. Lawrence: University Press of Kansas, 2016. Pp. 304. \$34.95 (hardcover).

Who serves in the American military and how does the government enact policies to facilitate the buildup and maintenance of its military strength? Since the founding of the nation, military service and citizenship were wedded themes. The sense of duty and pledge of support or direct participation in the defense of first settlements and then colonies were later expanded to the nation when George Washington first proclaimed it in his "Sentiments on a Peace Establishment" letter to Alexander Hamilton in 1783. So wedded were these two throughout American history that even underrepresented minorities recognized the importance of service as the path toward their larger dream of equality and clamored to invest themselves in the defense of their nation. Throughout history, motivations for service have changed and so have the policies the American government has implemented to provide for its defense. In Military Service and 
American Democracy, William A. Taylor provides a comprehensive account of service and related government policies in a pivotal time period, where the goals of the military shifted from the grand campaigns of World War II based on annihilation strategy, to the limited efforts to maintain hegemony throughout the world that characterized the Cold War period and beyond.

Highlighting that the military was vastly under strength in 1939 at the outbreak of the Second World War, Taylor discusses how the establishment of the first peacetime draft facilitated a move toward unprecedented mobilization. The author shows that within a year from when President Franklin D. Roosevelt initially signed the Burke-Wadsworth Act (Selective Training and Service Act of 1940) into law, the peacetime draft registered more than 17 million Americans, placed nearly 1 million of them directly into military service, and made 2 million more available. Equally interesting was that the Selective Service System motivated Americans to enlist as well. As such, Taylor argues that the draft was the critical mechanism that allowed for mobilization during World War II. Using excellent sources from the director of the Selective Service System, the book depicts the growing debate during the period on how the Selective Service System was supposed to organize classifications that dictated who was allowed to register and serve. As any new system, it was rife with inconsistencies, and Taylor highlights the many instances of fraud and the issues of dealing with immigrant and minority communities. The author shows evidence of the widespread support the Selective Service System garnered among the population, which is important given that the magnitude World War II necessitated that the United States harness public support for the war effort.

Equally important during and after the war was the idea of universal military training (UMT), devised largely by General John M. Palmer and promoted vociferously by George C. Marshall as the way forward in establishing a sufficient troop base to call on in times of national emergency. Taylor provides a detailed account of the development, promotion, and initial supporters of UMT and its eventual demise under President Dwight D. Eisenhower. With his skilled narrative of policies and personalities in the section of the War Department concerning manpower, Taylor continues to demonstrate his position as the authority on UMT, as established by his earlier work on the subject, Every Citizen a Soldier: The Campaign for Universal Military Training after World War II (2014). In both cases, he describes the demise of the UMT ideal and the U.S. government's decision to look toward the draft to fulfill its needs. The draft was subsequently used during the wars in Korea and Vietnam, however, as Taylor discusses the issues of discrimination, which were rife within the Selective Service System. Particularly on matters concerning race and socioeconomic class, the Selective Service System allowed for individual prejudices on draft boards. Prejudice on draft boards would become even more divisive as the Afri- 
can American population felt they were bearing the majority of wartime deaths in Vietnam.

Eventually, the inconsistencies and complexities in managing prejudice and discrimination in the Selective Service System became taxing for sitting administrations. Taylor highlights the problems the Lyndon B. Johnson administration faced during the height of the civil rights movement and the trouble the Richard M. Nixon administration had in maintaining support in the wake of the Tet Offensive and in the scrutiny he received over his Vietnamization policy. With the responsibility of the war being handed over to the Republic of Vietnam, people questioned the need to maintain the draft system. In this climate of change, Taylor examines the move toward the all-volunteer force (AVF) that had been used by the U.S. government since 1973. That move, Taylor notes, required significant changes to military culture and created a system based on incentives. The government could no longer appeal to possible recruits based merely on their sense of patriotic duty as was the case during World War II. Signing bonuses, better housing options, and a lessening of traditional military customs had to be implemented to mirror the recruiting practices employers used in civilian society. Such practices, the government thought, would sustain the nation's recruiting goals and provide for the development of a professional force.

The AVF was a significant departure from the traditional Selective Service System in many ways. One of the most significant changes was the growing number of women serving in the military. The book highlights major policy changes regarding women serving in the military, such as the Women's Armed Services Integration Act of 1948, George C. Marshall's creation of the Defense Advisory Committee on Women in the Services (DACOWITS) in 1951, and when Congress lifted formal restrictions on women serving in 1967. However, Taylor maintains that declining male enlistment rates after the move to an AVF created an impetus to actively recruit and enlist women and also notes how the AVF facilitated changes on policies regarding sexual orientation in the military, first with Don't Ask, Don't Tell and later with its repeal. These successes in open recruitment policy represented positive changes under the AVF system.

Skillfully providing a balanced account of the AVF system, however, Taylor notes major criticisms as well, which largely surrounded the issue of minority and socioeconomic class. While the AVF was instrumental in developing a professional force, it also provided an opportunity for poorer, underrepresented individuals who could not find work in the civilian sector to find gainful employment in the military.

In the latter portion of his exploration of military service, Taylor critically analyzes the success and failures of the AVF with respect to the wars in the Middle East. He details the rise of private contractors who fulfill traditional 
roles assigned to military servicemembers. His exploration of the difference between private military contractors and those tasked with security is incisive and particularly illuminating when he analyzes the ratios of these groups who have operated in Iraq and Afghanistan — and the high number of negative incidences and crimes against humanity that have resulted. Reminding readers of the resurgence of patriotism in the wake of the 9/11 attacks, the book also highlights the greater steps made to ensure equity within the military system, namely with the more recent legislation allowing women to serve in billets they have been traditionally barred from.

Military Service and American Democracy should be considered essential reading for those interested in understanding the modern American military. Taylor has combed the sources of multiple archives and presidential libraries and referenced solid works dealing with civil-military relations and military strategists form the time of Emory Upton. Although this work would speak to a wide general readership, it should be considered mandatory for U.S. military historians, particularly those who are interested in manpower policies related to the draft, UMT, and the development of the AVF. Taylor's work adds a new dimension to the scholarship on civil-military relations in the United States, and he establishes himself with this work as one of preeminent authorities on such matters. His work fits very well into a select body of scholarship, namely, Andrew J. Bacevich's "Whose Army?," in David Kennedy's The Modern American Military; Brian McAllister Linn's The Echo of Battle: The Army's Way of War; and Beth Bailey's America's Army: Making the All-Volunteer Force. Any serious scholar of U.S. military history from 1900 forward should include this in their must-read list. Any student of African American or women's history would also find Taylor's analysis of the roles of both groups in military and civilian sectors insightful.

Jeremy P. Maxwell

PhD student

University of Southern Mississippi

A Military History of Afghanistan: From the Great Game to the Global War on Terror. By Ali Ahmad Jalali. Lawrence: University Press of Kansas, 2017. Pp. 634. \$34.95 (hardcover)

Ali Ahmad Jalali's A Military History of Afghanistan is a survey of 2,000 years of Afghan history, with an emphasis on the last two centuries. Jalali is the Afghan ambassador to Germany and a professor at the Near East South Asia Center 
for Strategic Studies at National Defense University. Jalali also served as interior minister in Kabul from January 2003 to September 2005. The author uses primary and secondary sources, interviews, and his deep knowledge of Afghan history and politics to delve into the long and rich history of military affairs in Afghanistan. Often called the graveyard of empires, Afghanistan has more often been an integral part of empires and a crossroads of civilization in Central Asia. Although styled as a military history, the book contains heavy doses of political and diplomatic matters as well. It is an excellent resource for those interested in understanding the history underpinning Afghanistan's current challenges.

Mark Twain once commented that if history does not repeat itself, it does rhyme, and the history of Afghanistan proves the point. The struggle of Afghan tribes against the Mughal Empire in India in the sixteenth and seventeenth centuries sounds not dissimilar to the war in Afghanistan today. Jalali writes:

Mughals never succeeded in establishing firm control over the hilly country of Swat, Bajaur, Buner, Tirah, Waziristan, Paktia, Kunar, and the mountainous tract east of Kabul, but they were able to exploit the internal tribal feuds by making separate deals with the clansmen and enlisting the cooperation of the willing against the irreconcilables. (p. 57)

The challenges faced by the Mughals and their solutions to them could have come right out of the counterinsurgency playbook, a distant mirror of today's challenges in Afghanistan.

Western intervention in Afghan affairs began early in the nineteenth century and continued for roughly 100 years in what historians have termed the Great Game, pitting Russia and Great Britain in a struggle for dominance in Central and South Asia. Afghanistan was weak and divided and outside powers were able to use factional disputes to their advantage. "It is often said that for any invader it is easy to enter Afghanistan but hard to leave," Jalali claims, and the subsequent history he relates of the Western presence in Afghanistan provides evidence of this quagmire that Afghanistan represents (p. 117).

The history of Afghanistan in the nineteenth century should be a warning to foreign powers interested in dominating the Afghans. A Russian-backed Persian invasion of Herat in 1837 spurred the British, fearful of a Russiandominated Afghan state on the Indian frontier, to seek regime change in Kabul. The resulting invasion by British and Sikh troops led to the installation of a puppet on the throne in Kabul, but the subsequent occupation of the country to solidify his power was a disaster and resulted in decades of hostility between Afghan tribes and Great Britain. A tribal uprising in November 1841 led to the retreat of the 4,500-strong British contingent (plus 12,000 camp followers) from Kabul two months later. The Afghans ambushed the force and massacred 
the troops and camp followers, minus a regimental surgeon, the sole survivor of the column to reach the safety of the British garrison at Jalalabad. Ironically, the ruler the British had displaced from power four years earlier-Dost Mohammad Khan-resumed power and became a British ally. The war had cost the British 10,000 soldiers and 17 million pounds sterling, only to see the situation at the end return to the status quo antebellum.

British control of India (of which modern-day Pakistan was a part until 1947) has colored the modern history of Afghanistan. The 1893 demarcation of the border of Afghanistan with British India, the Durand Line, bisected the powerful Pashtun ethnic group, creating the foundation for generations of conflict in the border regions - a situation made even worse by the creation of Pakistan in 1947. Relations between Afghanistan and Pakistan have remained strained ever since, one more example (the Kurds being another) of how Western colonialism, in dividing peoples, has created many of today's most intractable security challenges. During the Cold War, the Soviet Union was more than willing to side with Afghanistan in the border dispute against the U.S. ally Pakistan. Soviet military assistance also helped to modernize the Afghan military forces, with significant ramifications for the future.

Readers will be most interested in the final 200 pages of the book, which cover the Cold War, the coup that overturned the Afghan government in 1978, the Soviet invasion of Afghanistan, the resistance of the mujahideen to the Communist government in Kabul, the rise of the Taliban, and the American invasion of Afghanistan in 2001 and its aftermath. The Communist coup in April 1978 ushered in 40 years of violence that has yet to abate. The Soviet Union invaded Afghanistan to prop up the unpopular Communist government, which led to the formation of the mujahideen guerrillas, the latter supported by Pakistan and Saudi Arabia and in time the United States as well. The withdrawal of Red Army forces in 1989 and the end of financial assistance after the breakup of the Soviet Union in 1991 led to the collapse of the Communist government and ushered in a period of civil war and the rise of the Taliban. Americans are all too familiar with the rest of the story: the sanctuary given Osama bin-Laden and al-Qaeda by the Taliban, the attack on America on 11 September 2001, the U.S. invasion of Afghanistan that followed, and U.S. and NATO military operations to bolster the Kabul government now nearly two decades in the making.

Jalali thoroughly covers the U.S. invasion of Afghanistan and the early years of the occupation and war against the Taliban, as well as providing insights into the political situation that alienated the bulk of the Pashtuns and ensured a continuation of the war once the Taliban fell from power. Nevertheless, those readers interested in an in-depth account of the fighting since 2001 would do better to look elsewhere. The strength of this book is the deep military history of Afghanistan, which provides context to what is only the most recent war in a 
country that has witnessed countless conflicts over several millennia of human civilization. A Military History of Afghanistan is recommended for military and Central Asian historians, policy makers grappling with the manifest challenges of creating stability in Afghanistan, diplomatic and military personnel assigned to the region, and general readers interested in delving deeply into the military history of one of the oldest and most contested crossroads of civilization.

Peter Mansoor

General Raymond E. Mason Jr. Chair of Military History

The Ohio State University

America's Digital Army: Games at Work and War. By Robertson Allen. Lincoln: University of Nebraska Press, 2017. Pp. 228. \$65.00 (hardcover); $\$ 30.00$ (paperback and e-book).

In 2002, the U.S. Army released America's Army, a game technology platform used for first-person shooter video games. With its surprisingly authentic portrayal of soldier life, training, weapons, and combat, the America's Army game promptly became an overnight success. Critics were astounded that the U.S. government could actually produce an engaging, top-quality video game and give it away for free. The game's popularity soon led to licensing arrangements, resulting in versions suitable for PlayStation 2, Xbox, Xbox 360, arcade, and mobile applications.

In 2005, America's Army caught the attention of Robertson Allen, a firstyear anthropology graduate student living in Seattle, Washington. Allen was uneasy about the Army releasing a war-related video game embraced by millions of adolescent boys. His reservations, however, were not about the violence in the game. After all, he was himself an avid player of military first-person shooter games, and he summarily dismissed any notion that video games led to increased levels of aggression. Instead, he was apprehensive about the underlying ideological messages conveyed by the game, particularly that everyone coming into contact with America's Army was being enlisted, militarized, and placed into a potential labor pool of virtual soldiers. His concerns were the impetus for a multiyear ethnographic study examining the development, fielding, and implications of the America's Army game. Allen published his findings in journal articles and book chapters, which were then compiled to form the basis of America's Digital Army.

Allen's inquiry into America's Army began when he emailed the game's creator and director, Colonel Casey Wardynski, and stated that he would like to 
examine the behind-the-scenes process of military game development. To Allen's surprise, Wardynski invited him to an introductory meeting. Wardynski was an economist and director of the Office of Economic and Manpower Analysis (OEMA) at West Point. (Full disclosure: the reviewer backfilled Wardynski's position in OEMA from 1997 to 2000 while he obtained his PhD but was not involved with the America's Army initiative.) As an economist, Wardynski understood the difficulties of recruiting from a society that knew very little about the Army. As a parent, he understood the allure of video games in the lives of young American males - the Army's primary market for recruiting. America's Army used the entertainment value of video games to normalize the Army for the average American teenager as something within the youth's world of experience and possibility. The America's Army game was designed to be a vehicle that cost a fraction of other marketing efforts and yet was capable of holding the attention of the prime recruiting market for hours at a time.

Wardynski was careful to point out that, while the game allowed potential recruits to participate in virtual combat as entertainment, it also exposed young people to how soldiers work as a team, showed that Army values (e.g., integrity) were central to being a soldier, and revealed that soldiers operate within rules (e.g., shoot your drill sergeant and your avatar goes to Leavenworth). The game essentially allowed potential recruits to test-drive the Army-to see if it would be a good fit for their future. In addition to providing the rationale behind America's Army, Wardynski surprised Allen with carte blanche access to the network that created and continued to develop the game. With Wardynski's permission, Allen was able to communicate with, observe, work beside, and even bond with individuals involved in the development of America's Army at locations in San Francisco, Los Angeles, Huntsville, Philadelphia, Seattle, Indianapolis, and West Point.

With open access to the America's Army network, Allen immersed himself in all aspects of the game. He observed the Virtual Army Experience (VAE) - a life-size America's Army simulator erected at state fairs, air shows, and other high-traffic venues that featured mock-up humvees and Sikorsky UH-60 Blackhawk helicopters. As participants waited for their turn in the simulator, Army recruiters and drill sergeants were on hand to chat about military occupations and opportunities. Once in the simulator, visitors received a briefing on the upcoming mission and were then escorted to the humvees and Blackhawks. Because participants sometimes had to stand in line for more than half an hour for the VAE, Allen observed that many would opt to sit in the seats of the humvees instead of standing to handle the M249 light machine guns. Allen's subsequent interpretation of that observation reflects his primary concern with America's Army:

This, I contend, is one of the microlevel purposes of the VAE: 
to introduce the army's technologies and weapon systems to the general public so that civilians would, for instance, be able to make a more informed decision as to which vehicle or which seat in a U.S. Army Humvee is more appropriate for them to ride in. In the minutiae of such options and necessary decisions virtual soldiers are thus fashioned. (p. 96)

Another part of America's Army that attracted Allen's attention was the Real Heroes program. Real Heroes were actual Army soldiers who had received valor awards and represented an ideal of personal achievement. Three-inch G.I. Joestyle action figures depicting each Real Hero were distributed as promotional merchandise and several Real Heroes toured the country with the VAE. The Real Heroes program extended America's Army beyond the virtual and allowed the public to rub elbows with an actual hero. Allen focuses on Real Hero Army Sergeant Tommy Rieman, a Silver Star recipient who was honored during the State of the Union address in 2007.

Despite the national recognition, Rieman battled post-traumatic stress disorder (PTSD) and alcoholism, which eventually cost him his marriage and home. Rieman has since become a spokesman for veteran issues and life after injury, but Allen points to the omission of Rieman's struggles in his Real Hero character as another piece of evidence of the surreptitious militarization of American society. By ignoring the potential trauma experienced by soldiers, America's Army had become an "ostensibly safe domain that can be inscribed and coded with institutional messages" (p. 88).

Allen's anthropological search for coded institutional messages is the main focus of the book. In every aspect of the America's Army game, from the locally hired young women who register visitors into the VAE, to the programmers and artists designing the game, to the tractor trailer drivers contracted to haul the simulators, to even Allen in his role as a researcher anthropologist, Allen sees the military deliberately transforming individuals into virtual soldiers-people whose labor could be militarized in some form. Allen goes on to explain how this is problematic:

Virtual soldiering is not an individual choice that people are at liberty to make, but rather the result of an institutionalizing force that spreads as a pervasive element through the society of control. In this sense everyone is essentially a virtual soldier. (p. 37)

Allen's tendency to attribute deep meaning to everything is evident in the final story of the book. Wardynski-who was sometimes referred to as the 
godfather of America's Army - was bantering with Allen and some government executives at a conference when he turned to Allen and asked if he had seen the Godfather movies. Allen replied that he had, and Wardynski then asked, "You're a good guy, right?. . . . I hope you are because otherwise I'll have to take care of you and kill you" (p. 161). Despite admitting that the context of the exchange was clearly "in joking hyperbole, during a casual hallway conversation with other Army Game Project executives," Allen cynically concludes that Wardynski's threats, "however metaphorical and offhand, were not to be taken lightly" (p. 162).

Although America's Digital Army is an engaging, well-researched book about an innovative Army recruiting initiative, Robertson Allen's intent is to raise alarm over what he perceives as the darker, ulterior motives behind America's Army. Of course, an alternative interpretation could simply be that "sometimes a cigar is just a cigar."

Leonard Wong, PhD

Research professor

Strategic Studies Institute, U.S. Army War College

Algeria Modern: From Opacity to Complexity. Edited by Luis Martinez and Rasmus Alenius Boserup. New York: Oxford University Press, 2016. Pp. 256. $\$ 70.00$ (hardcover).

True to its subtitle, this brief and readable volume helps move analysis of Algeria's contemporary political life beyond vague invocations of le pouvoir and simple surrender in the face of obscurity and ambiguity. Through their own contributions and those of other scholars working in North Africa, Europe, and the United States, the two editors forge a compelling account of Algeria's political and social evolution since the violence of the 1990s. It is the story of an Algerian elite playing official politics as an insiders' game, even as fundamental structural tensions grow. It is also the story of Algerian youth mobilizing to communicate their demands and transforming their culture and society, but also at a remove from an ossified order run by an aged president who offers post-conflict stability but no vision of renewal.

The chapter by Luis Martinez, senior researcher at CERI Sciences Po in Paris, looks mainly at Algerian politics and society from above. He analyzes struggles among interest groups — the army, presidency, unions, intelligence services, political parties — that inhabit, compete within, and occasionally bypass 
Algeria's formal political institutions for their own benefit. The fate of Islamist politics within this resilient system is described by Djallil Lounnas. In addition to repressing violent radicals, the regime manipulates the political sphere to manage the Islamist challenge, engineering the inclusion of nonviolent parties and leaders in ways that make them more moderate and democratic in orientation, yet more fragmented and marginalized politically. But Algeria faces critical structural constraints left unaddressed by these maneuvers. The Algerian elite, Samia Boucette argues, is unable to meet popular expectations of national development through hydrocarbon revenues or to overcome rentier state dynamics by modernizing and diversifying Algeria's economy. And Abdennour Benantar goes on to show how Algeria's security policy — an isolationist dream of nonintervention (of Algeria's military), noninterference (in neighbors' affairs), and noninvolvement (by foreign powers) - is coming apart in the face of crises in next-door Libya and Mali and of interventions in the region by France, NATO, the UN, and others.

The chapter by Rasmus Alenius Boserup, senior researcher at the Danish Institute for International Studies in Copenhagen, focuses on Algerian politics and society from below. With formal institutions unresponsive, ordinary Algerians have developed contentious politics through new repertoires of contestation and protest aimed not at overthrowing the regime but rather at petitioning for state resources (e.g., subsidies, housing, employment, and infrastructure) or advocating for regional recognition, as in the case of Kabylia and the Sahara. Anouar Boukhars studies in detail the popular politics of the southern protests, teasing out their security and diplomatic implications. Ed McAllister, meanwhile, looks at social and political forces at work in one Algiers neighborhood. McAllister's contribution to this book is remarkable. In addition to translating (from French) the introduction and three chapters into clear prose, he writes a sort of pocket ethnography of the Algerian youth of Bab el-Oued-their identities and subgroups; their music and style; their cynicism, nostalgia, and political disaffection; and their everyday acts of resistance and creativity. McAllister's vignette includes quotations from his conversations with Bab el-Oued residents, and overall this volume brings to an English-language audience a number of fresh sources, including a variety of French-language books, chapters, news articles, policy analysis, and official documents-conveniently gathered into a single bibliography.

In sum, Algeria Modern depicts a country outgrowing its established system yet unprepared to shed its skin, which raises a number of questions. Will Algeria evolve toward some new equilibrium that leaves ersatz political institutions in place, while real competition and decision making occurs in parallel, through more formal arrangements that frame interest-group rivalry and popular pro- 
tests? Or will some combination of low oil prices and depleted reserves, regional instability and insecurity, and internal pressures and demands break down Algeria's current order, clearing the way for something new? Either way, Algeria is on the move, and Martinez and Boserup strike a note of optimism at the close of their introduction. Algeria is perhaps uniquely positioned among major Arab powers, they claim, for a political transformation away from authoritarianism. In whatever way the country evolves, this volume accomplishes its goal of elucidating the forces at work in contemporary Algeria.

Benjamin P. Nickels, PhD

Associate professor of counterterrorism and counterinsurgency

Africa Center for Strategic Studies

The Prometheus Bomb: The Manhattan Project and the Government in the Dark. By Neil J. Sullivan. Lincoln: Potomac Books, an imprint of the University of Nebraska Press, 2016. Pp. 296. \$29.95 (hardcover and e-book).

Los Alamos, New Mexico, is a place of mystery and beauty. One could imagine what life was like as one of the most revolutionary secrets in Western history, the Manhattan Project, was steadily unfolding in such a geographically inaccessible place. It was a true race against time as the Axis powers enveloped Europe and East Asia. The story is well-documented; what is not is the innovative and engaging argument found in Neil Sullivan's The Prometheus Bomb-that decisions, ideas, secrets, and approaches to scientific endeavors were at times based in trial and error. At several points, the U.S. government really spent much of its time fumbling around in the proverbial dark, while scientists spilled secrets and probably indirectly assisted the Russians in obtaining the intelligence they would need to build their own bomb. With all the recent controversy over security clearances at the Donald J. Trump White House, especially concerning his son-in-law's access to secrets, this book seems a timely contribution.

Sullivan, a professor in the Marxe School of Public and International Affairs at Baruch College, CUNY, is a cagey writer and wordsmith. He possesses an elegant prose to communicate how a bunch of scientists spoke a language that few within the government understood. How these threads were woven together was part luck and part personality. As Sullivan tells us, it really emanated from the brain of President Franklin D. Roosevelt, who made decisions early on to not only listen to men like Albert Einstein, but he also had the foresight to allow Leslie Groves, Vannevar Bush, and a host of others to negotiate and trans- 
late gibberish into action. The administration found clever ways to accomplish this prospect. First, with Groves urging, they restricted knowledge to a select group of trusted advisors. Yet, the road to Hiroshima and Nagasaki, Japan, was full of challenging choices. Namely, two prongs had to be pursued; first was the garnering of the necessary funding sources to compete with a German bomb development program; and second, trying to avoid congressional oversight, which constantly dogged them.

As we know, funding makes it all go. Wars are not fought by men alone; rather there must be a cash flow that gets the science moving to accelerate the technology. As Sullivan tells us, in an age before notions of national security, Roosevelt's administration hoped they were working toward something that could not follow previous arcs because the events at a squash court at the University of Chicago were so pathbreaking. What to do next perplexed them. If they followed procedure, then hearings would be held and public officials would openly scare the public with tales of misappropriation. An end run was needed and that meant secrecy. They found an amazing combination of yarn spinning, budgetary wizardry, and a place where they could hide the nearly $\$ 20$ billion they would require within the budget under the Army Corps of Engineers.

As mentioned, public officials were concerned, annoyed, and downright suspicious. As the story goes, one of their chief dissenters was none other than the man who would sit at Potsdam at the order for the dropping of the first and then second atomic bombs-Harry S. Truman. Then a senator, he chaired a committee that investigated government waste related to overt military spending. Sullivan is careful here not to fall into the trap of arguing that congressional oversight was constantly stymied. His consensus view is judicious, and he elegantly relates how some key members on the Hill were informed to block the release of secrets. What is most intriguing are the scientists who spend a fair amount of time writing what on the surface seem innocuous letters to friends and family; but, contained within these were important pieces of information that could be used by both the Germans and the Russians. In the end, Joseph Stalin knew more about the Manhattan Project than certainly most public officials. Resting on this fact alone, we might conclude that the government was in the dark, so to speak.

Yet, as Sullivan reminds us, that is part of the process and what a liberal democracy has to do at times when fighting a massive war on a global scale. Peppered throughout this book are allusions and context to the political and governmental developments that led to the coming of the Manhattan Project and beyond. Here, we find James Madison and his notions concerning enlightened leaders and their roles in Federalist Papers Number 10 and 51. As Sullivan states so adroitly, being informed is the key. By electing those minds that might 
not have scientific backgrounds but that possess an innate skill to faithfully realize what constitutes the public interest, we can take a stab at making the world safe for democracy - as long as they can pass an FBI background check, that is.

J. N. Campbell

Independent scholar, writer, and editor in Houston, Texas. He is the coauthor with Steven M. Rooney of the forthcoming title, A Time-Release History of the Opioid Epidemic (2018). 